DEPARTMENT OF THE INTERIOR

UNITED STATES GEOLOGICAL SURVEY

GEORGE OTIS SMITH, DIRECTOR

Profegsional Paper 79

\title{
RECURRENT TROPIDOLEP'TUS ZONES \\ OF THE UPPER DEVONIAN \\ IN NEW YORK
}

BY

HENRY \&. WILLIAMS

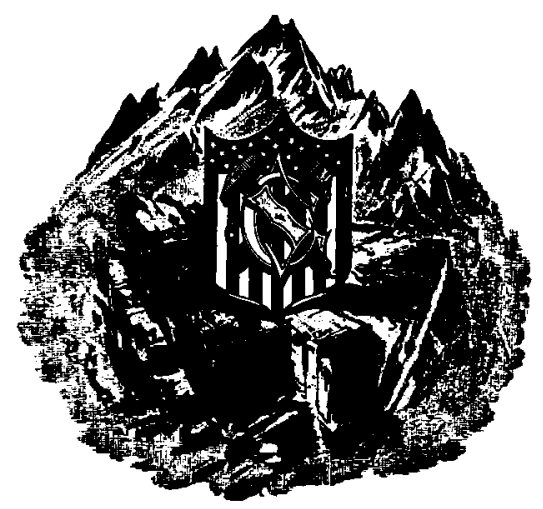

WASHINGTON

GOVERNMENT PRINTING OFFICE

1913 



\section{CONTENTS.}

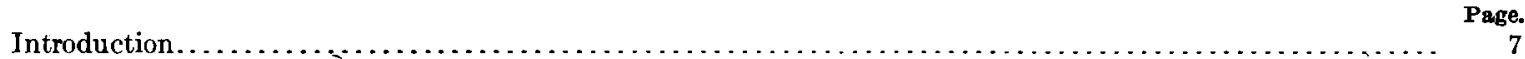

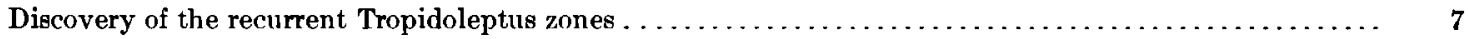

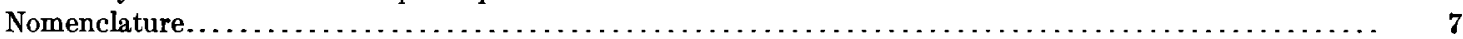

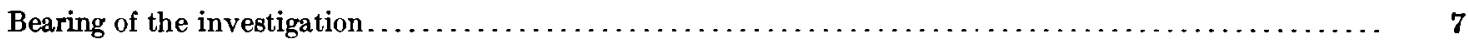

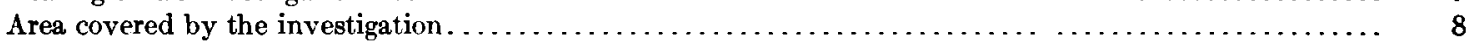

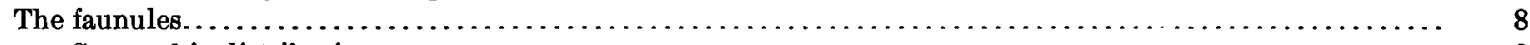

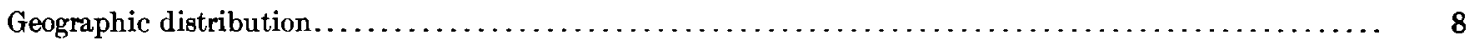

Faunal lists. . . . . . . . . . . . .

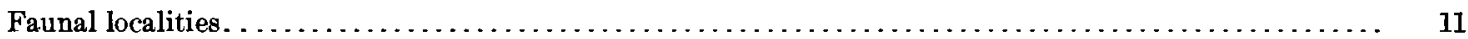

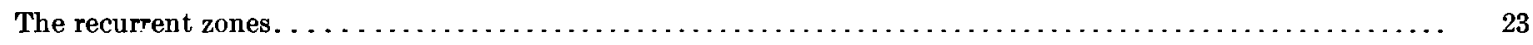

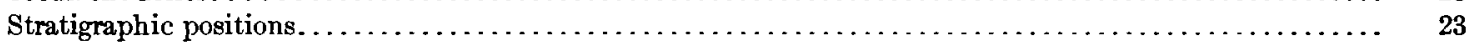

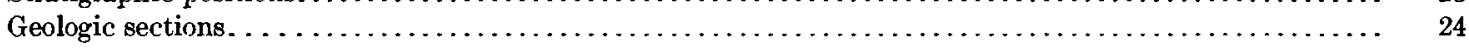

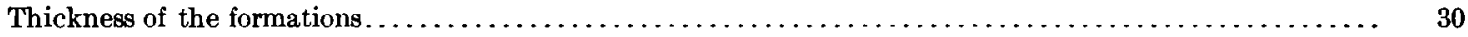

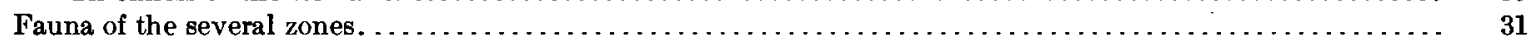

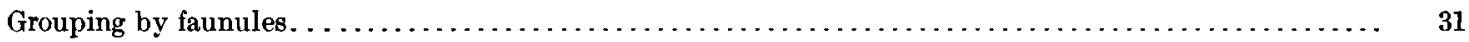

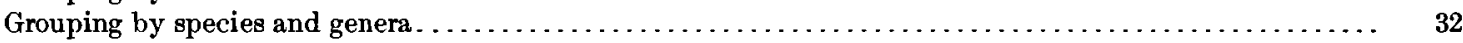

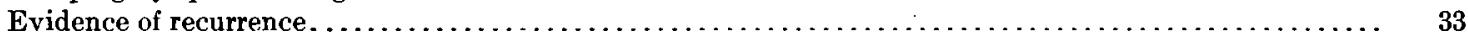

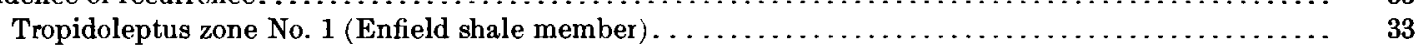

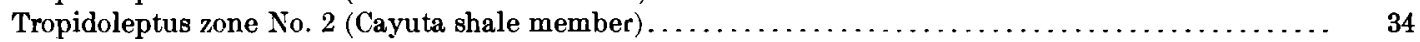

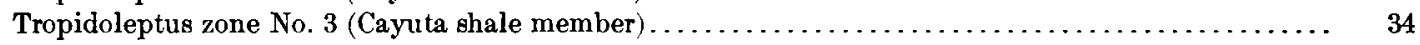

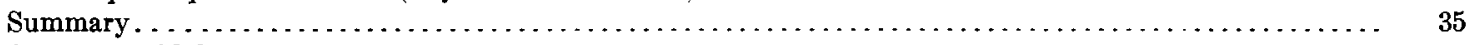

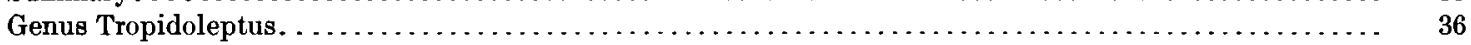

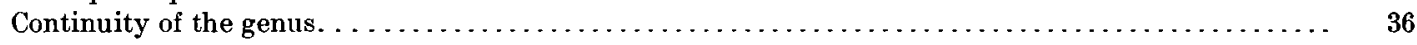

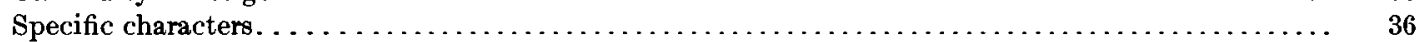

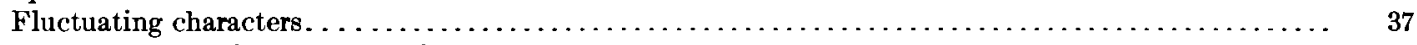

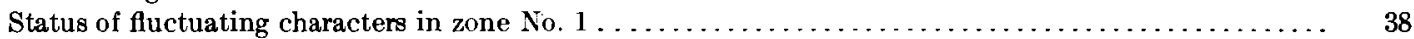

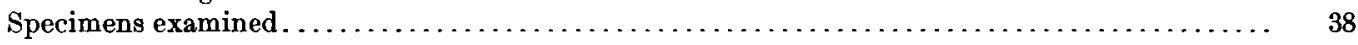

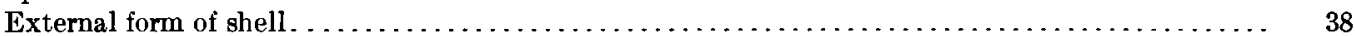

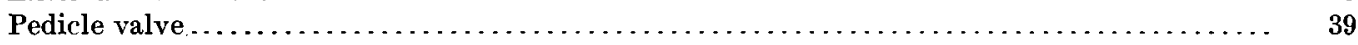

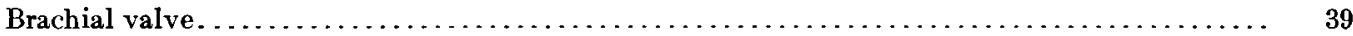

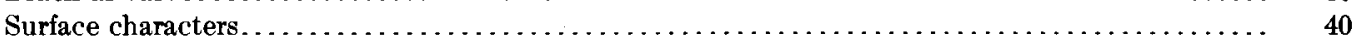

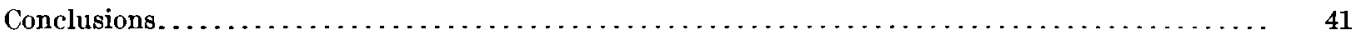

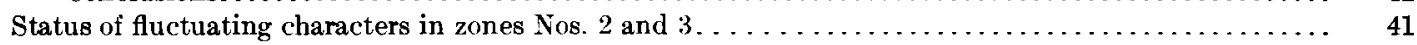

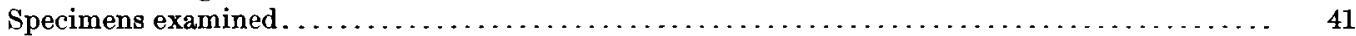

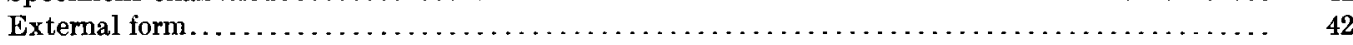

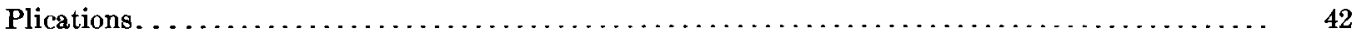

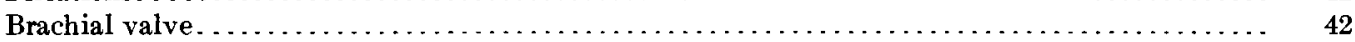

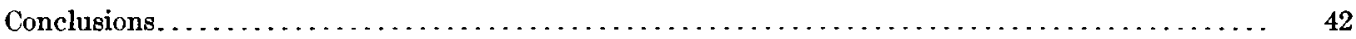

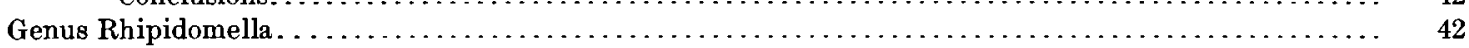

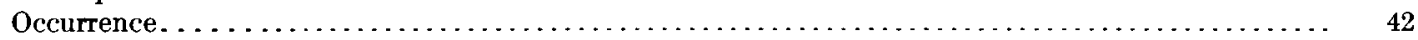

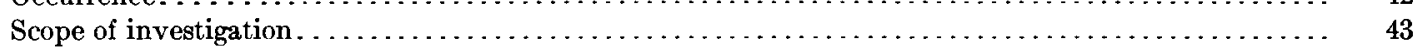

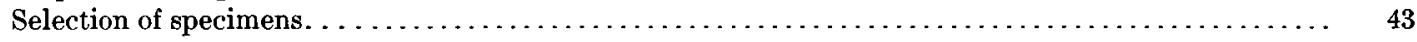

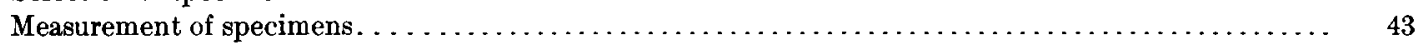

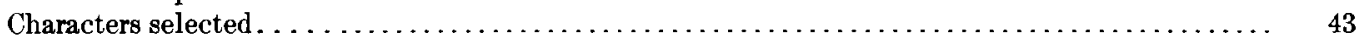

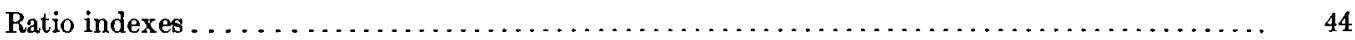

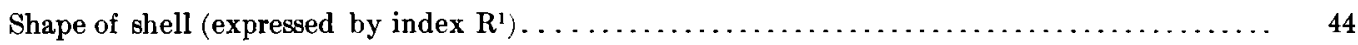

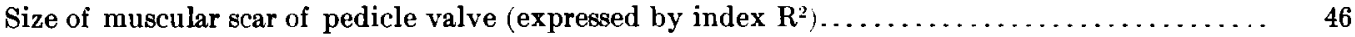

Shape of muscular scar of pedicle valve (expressed by index $\left.\mathbf{R}^{3}\right) \ldots \ldots \ldots \ldots$ 
Fauna of the several zones-Continued.

Genus Rhipidomella-Continued.

Specific discrimination. . .

Artificiality of present distinctions

Possible means of discrimination. .

Pedicle area.

Hinge teeth.

Median septum.

Muscular scars. .

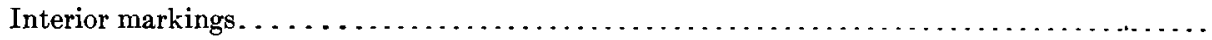

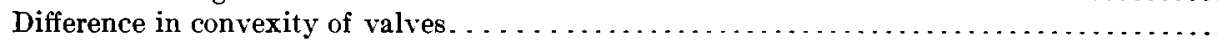

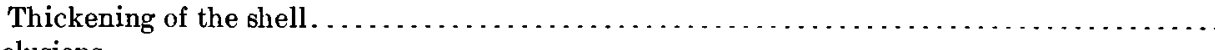

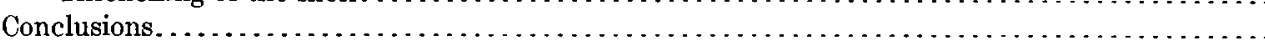

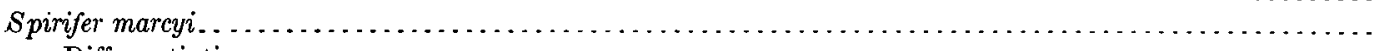

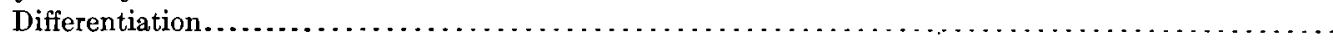

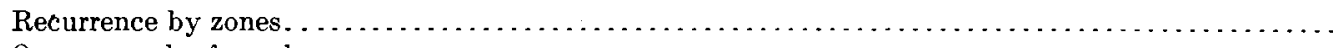

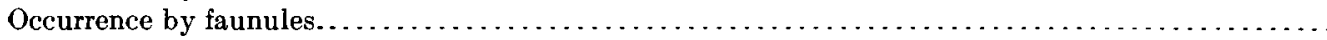

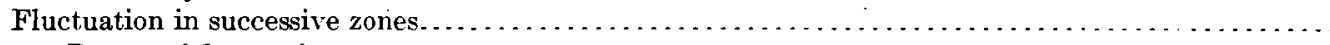

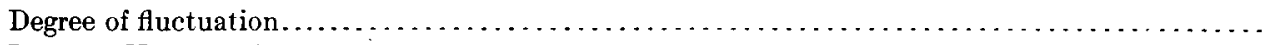

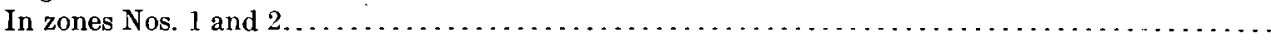

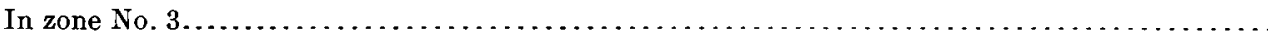

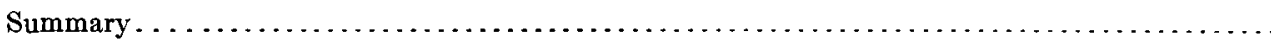

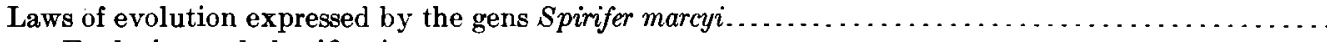

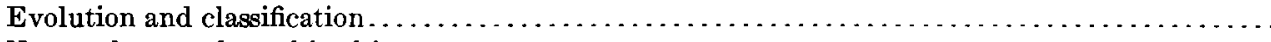

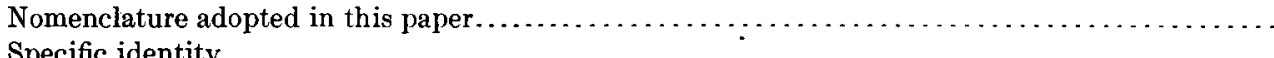

Specific identity....

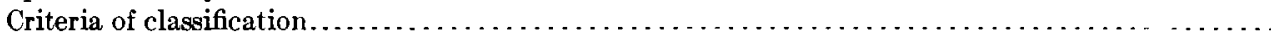

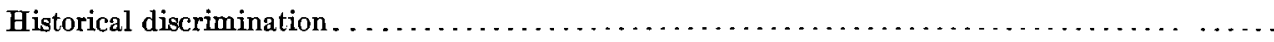

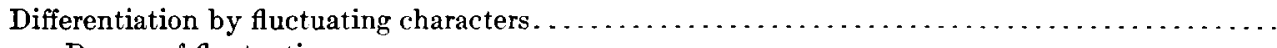

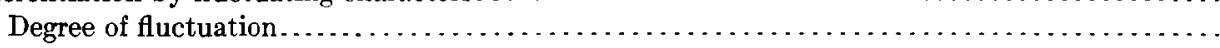

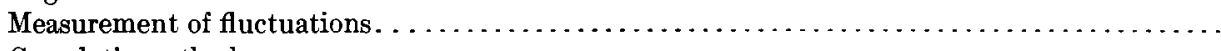

Gosselet's method.

Application of Gosselet's method to Spirifer marcyi . . . . . . . . . . . . . . . . . . . . . .

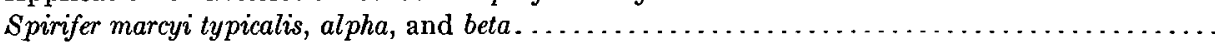

Spirifer marcyi gamma.

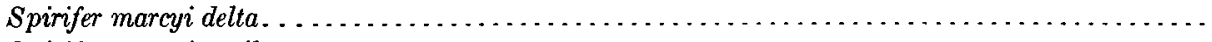

Spirifer marcyi epsilon.

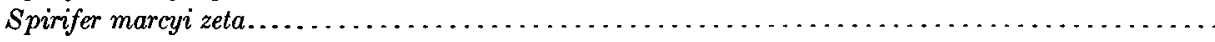

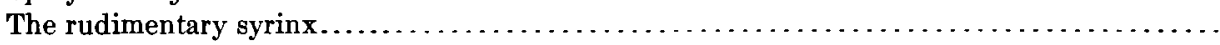

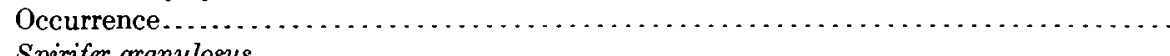

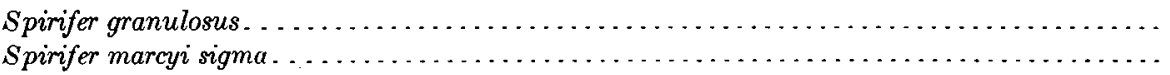

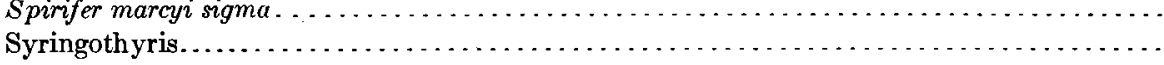

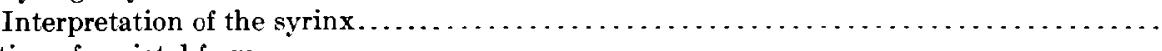

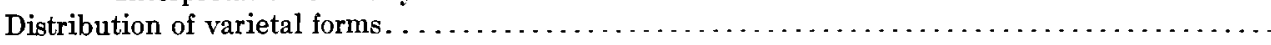

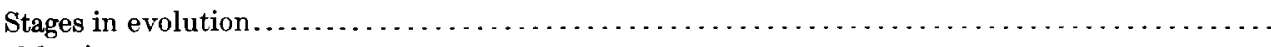

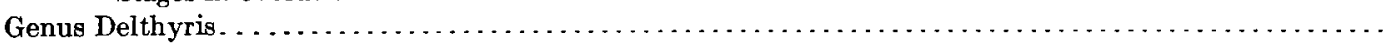

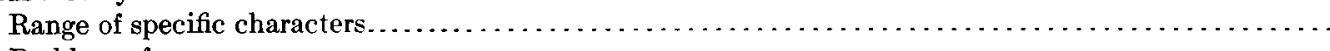

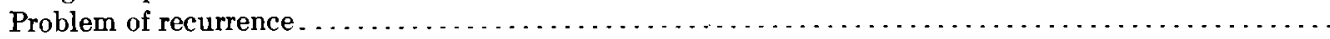

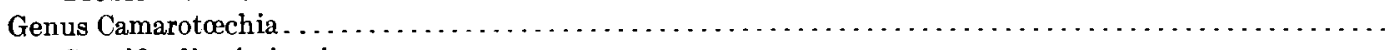

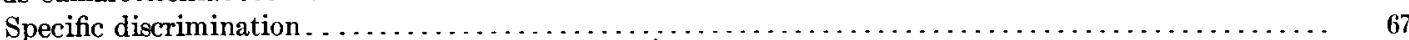

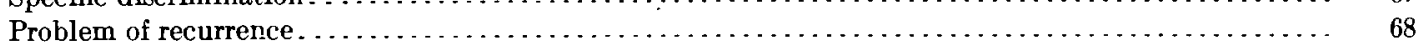

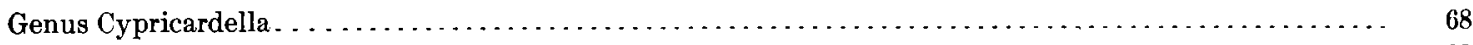

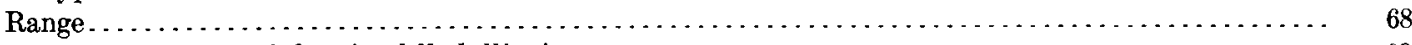

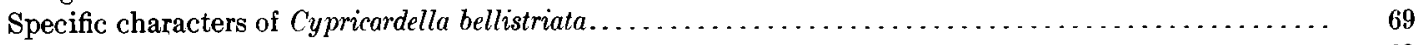

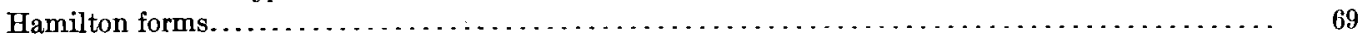

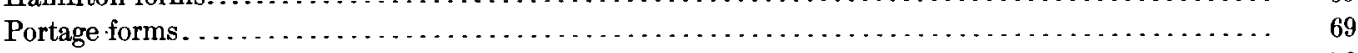

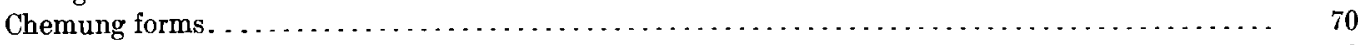

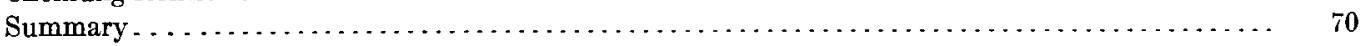

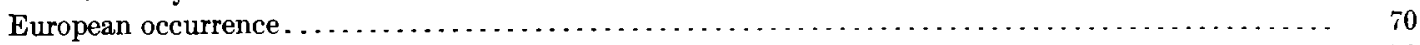

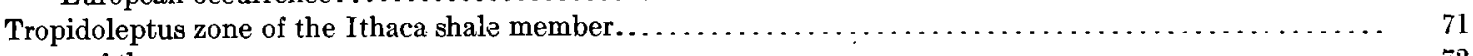

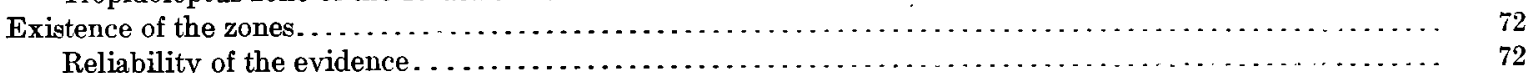


Existence of the zones-Continued.

Examination of the faunules.

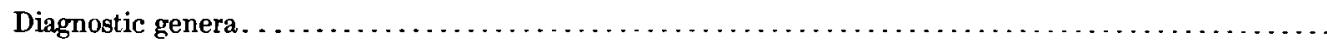

Associated species.

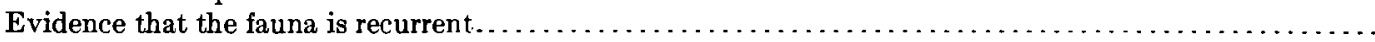

Criteria of recurrence.

Withdrawal of the fauna.

Return of the fauna.

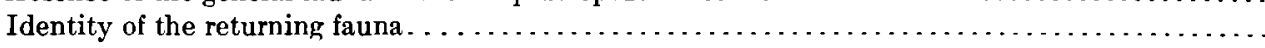

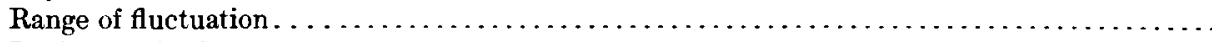

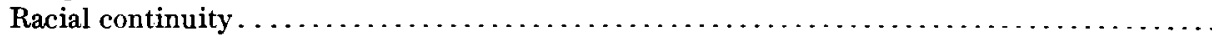

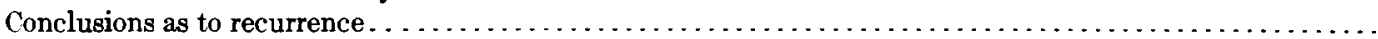

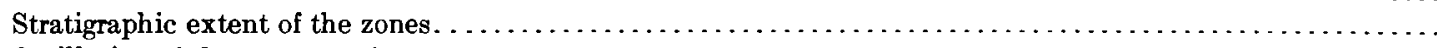

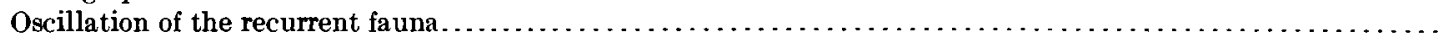

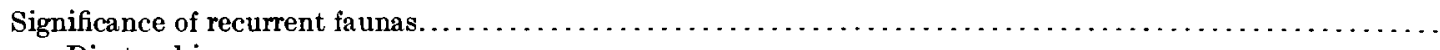

Diastrophism.

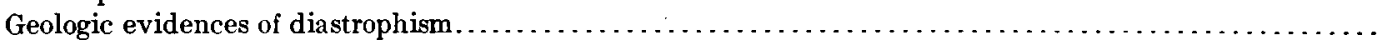

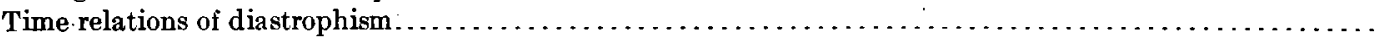

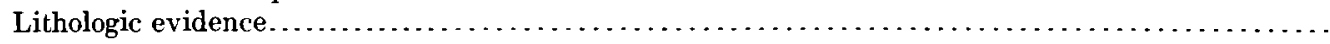

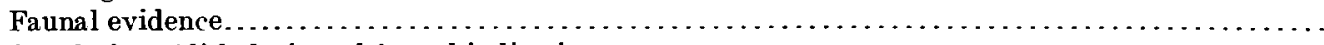

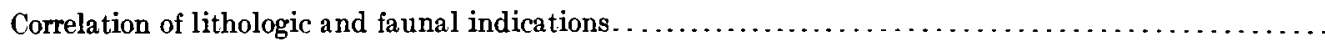

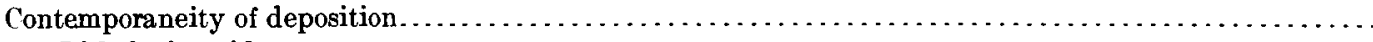

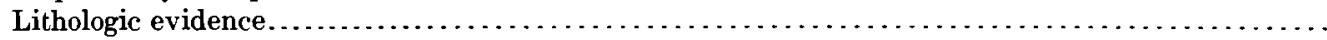

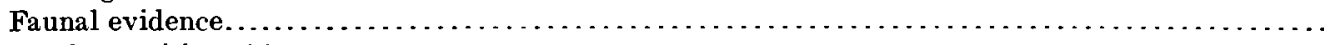

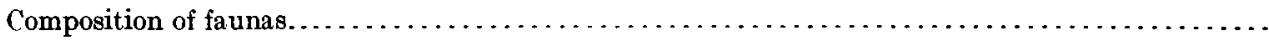

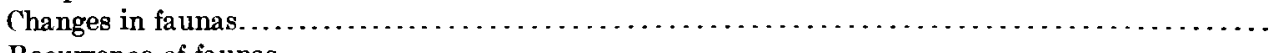

Index

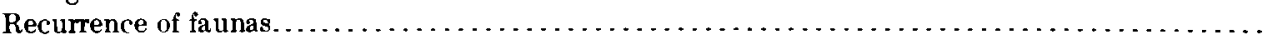

\section{ILLUSTRATIONS.}

Plate I. Tropidoleptus carinatus (Conrad)

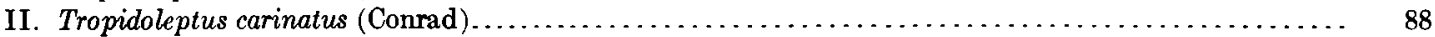

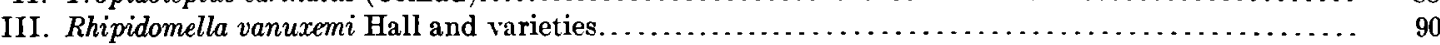

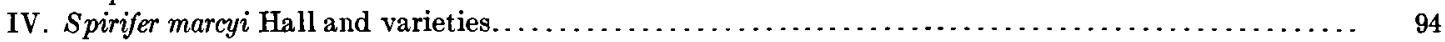

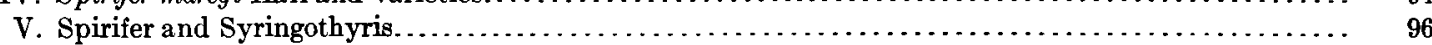

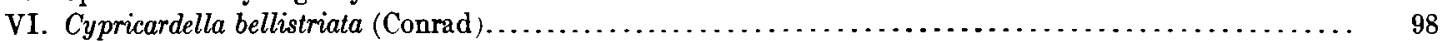

FIgURE 1. Index diagram, showing distribution and method of locating faunules in the 15-minute quadrangles composing the Watkins Glen-Catatonk area...

2. Faunal chart, showing the eastward invasion of the Portage and Chemung faunas and the westward invasion of the recurrent Hamilton fauna in the Watkins Glen and Catatonk quadrangles........

3. Sections at Taghanic Ravine, Glenwood. and Fall Creek.

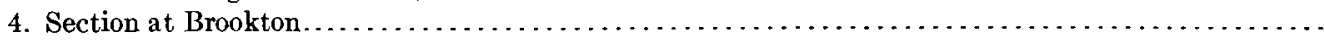

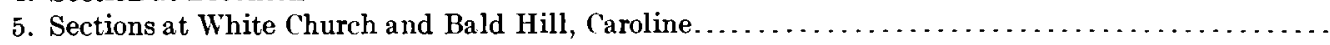

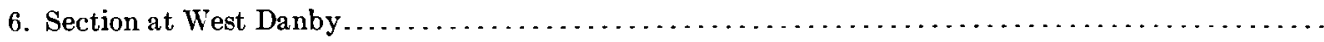

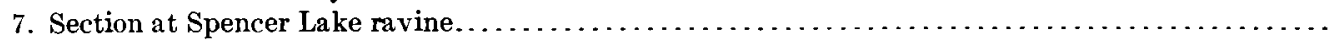

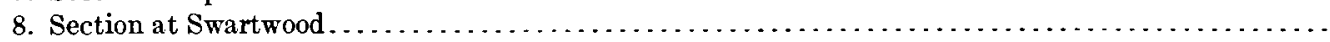

9. Sections at Glory Hill and Waverly.

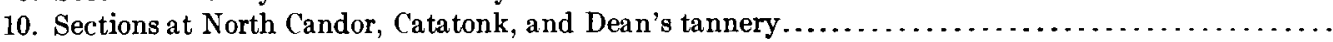

11. Sections at Hawley Hill; Water Street bridge, Elmira; Latty Brook; and Breesport..............

12. Sections at East Branch, Cortland; Blodgett Mills; and Messengerville and East Virgil . . . . . . . . . .

13. Sections at Marathon, Killawog, and Harford .

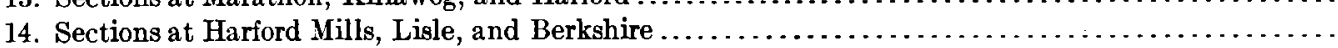

15. Cross section of beak of Spirifer granulosus sigma, showing rudimentary syrinx $\ldots \ldots \ldots \ldots \ldots \ldots \ldots$

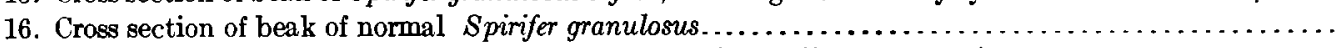

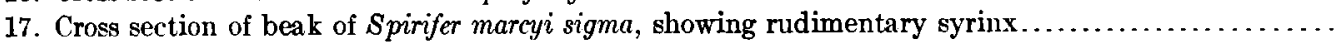

18. Cross section of beak of Syringothyris sp., showing complete syrinx. 



\section{RECURRENT TROPIDOLEPTUS ZONES OF THE UPPER DEVONIAN IN NEW YORK.}

By Henry S. Williams.

INTRODUCTION.

\section{DISCOVERY OF THE RECURRENT TROPIDOLEPTUS ZONES.}

In preparing the data for the Watkins Glen-Catatonk folio, ${ }^{1}$ the occasional finding of Tropidoleptus carinatus (Conrad) in strata far above the supposed range of the species or of the fauna with which the species is normally associated led me to make a critical search for that species and its associates and to observe and record the places in the sections and in the sequence of faunas where they appeared. The result was the discovery of four zones, three well-marked and one subordinate, in the Upper Devonian rocks, each of which contained several species that are common in the typical Hamilton formation of the Cayuga Lake section and are associated with very few of the really characteristic species of the faunas normal to the formations in which they are found. One of the principal zones is in the upper member (Enfield shale) of the Portage formation, and the other two are in the lower part (Cayuta shale member) of the Chemung formation. The subordinate zone is near the base of the Ithaca shale member of the Portage formation. (See fig. 2, p. 23.)

\section{NOMENCLATURE.}

These zones were called recurrent Tropidoleptus zones ${ }^{2}$ because of the conspicuous presence of Tropidoleptus carinatus in nearly every sample lot of fossils obtained from them. Subsequently ${ }^{3}$ I applied the names of Van Etten, Owego, and Swartwood to the three most conspicuous zones. The less conspicuous zone near the base of the Ithaca shale member of the Portage formation I called the Ithaca recurrent zone.

The United States Geological Survey is opposed to the application of geographic names to faunal zones, and accordingly in the Watkins Glen-Catatonk folio I called the three principal zones the first, second, and third Tropidoleptus zones. Although such usage in a scientific discussion of the faunas is open to the objection that, in the present state of knowledge, it is uncertain whether the zones mapped are the only recurrent zones of the kind in the series, yet in order to preserve uniformity in the nomenclature the same usage will be followed in the present report, and the terms zones No. 1, No. 2 , and No. 3 will be used to designate the recurrent zones at first called Van Etten, Owego, and Swartwocd, respectively. The subordinate zone will be called "the zone of the Ithaca shale member."

\section{BEARING OF THE INVESTIGATION.}

The importance of the investigation lies chiefly in its disclosures in regard to the ancient geography of the region. Both the departure and the return of the fauna must have been due to diastrophic changes that at one time brought about conditions unfavorable to the continued existence of the fauna and at another time not only restored favorable conditions but also provided means for the remigration of the fauna into the region. Such changes may have resulted (1) from the alternate closing and reopening of an actual passageway which alternately prevented and permitted the access of the fauna and of waters favorable to them, or (2) from changes that affected the direction, character, or volume of existing ocean currents.

\footnotetext{
1 Watkins Glen-Catatonk folio (No. 169), Geol. Atlas U.S., U. S. Geol. Survey, 1909. All references in this paper are to the field or octavo edition.

2 Williams, H. S., On the classification of the Coper Devonian: Proc. Am. Assoc. Adv. Sci., rol. 34, 1885, p. 226.

${ }^{3}$ Jour. Geology, vol. 14, 1906, p. 580; vol. 15, 1906, pp. 97, 108, 109. 


\section{AREA COVERED BY THE INVESTIGATION.}

The area covered by this investigation is included almost wholly in the Watkins Glen and Catatonk quadrangles mapped by the United States Geological Survey. These quadrangles lie in south-central New York, and each quadrangle comprises an area mensuring 30 minutes from north to south and from east to west and covering one-fourth of a square degree. Each has been subdivided into four smaller areas, 15 minutes in extent, known as the Watkins, Elmira, Ithaca, Waverly, Dryden, Owego, Harford, and Apalachin quadrangles. For convenience of reference in this paper each of these smaller quadrangles has been further subdivided into 1-minute blocks, designated by numbers ( 1 to 15) from east to west and by letters (A to $\mathrm{O}$ ) from north to south. The positions of all faunules and sections are given by reference to these 1-minute blocks. (See fig. 1.)

\section{THE FAUNUIJES.}

\section{GEOGRAPHIC DISTRIBUTION.}

In the work for this paper 1,411 separate faunules were collected and examined from the Watkins Glen and Catatonk quadrangles and 103 more from the adjoining Cortland quadrangle. All the faunules which contained either Tropidoleptus carinatus, Rhipidomella vanuxemi or closely allied forms, Spirifer marcyi, Cypricardella bellistriata, Delthyris mesicostalis, Fhacops rana, and other species either recorded in the Hamilton faunas or closely allied to them were critically examined.

As the stratigraphic position of these faunules was determined it was discovered that most of them were located in one or other of three definite zones in their respective sections. It was also ascertained (1) that none of the species were found stratigraphically far above or below the immediate zones in which they were often found in abundance and (2) that several of them associated together.

After all the faunules of the quadrangles under investigation had been studied and stratigraphically located, the faunules in each section containing any of these species were grouped together to form what I designated recurrent Tropidoleptus zones, considering Tropidoleptus to be the most characteristic form.

As the investigation proceeded I eliminated from the series all the faunules which did not contain at least one of the first four species mentioned above (all Hamilton species), regarding them all to be diagnostic representatives of the recurrent fauna. Those remaining constitute the 63 representative faunules of the recurrent Hamilton fauna listed (pp.11-23). All but one of them (No. 4 of the list) contain one of the first three species named. The fauna of No. 4 contains Cypricardella bellistriata and is high up in the Chemung; it was retained in the list because nowhere else in the Chemung has the species been recorded except in association with some one of the three diagnostic recurrent genera.

All but 2 of these 63 sample faunules were collected within the Watkins Glen and Catatonk 30-minute quadrangles. The two exceptions (Nos. 44 and 45) came from Blodgett Mills, in the southeastern part of the Cortland quadrangle, a few miles north of the northeast corner of the Harford 15-minute quadrangle. The 63 include all the faunules discovered in the areas containing the Tropidoleptus fauna. The distribution among the 15-minute quadrangles was as follows:

$$
\text { Distribution of faunules by 15-minute quadrangles. }
$$

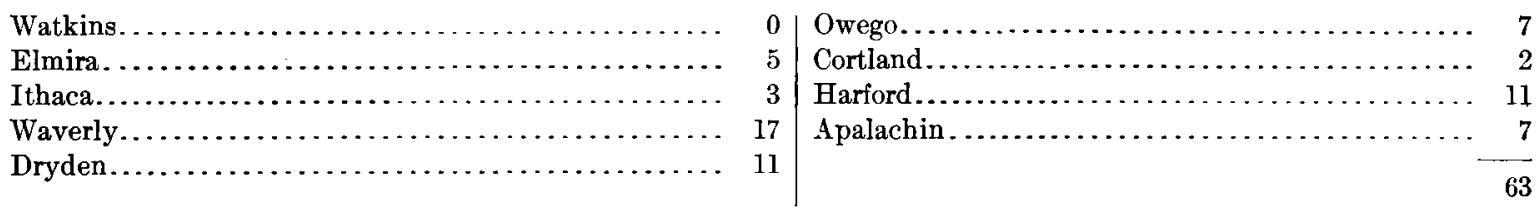

In the following list a serial number is given to each faunule for convenience of reference, and in the descriptions each is indicated by some geographic name (of a town, creek, or other natural feature) by which it may be located on a general map. It is further identified by its 
field label which bears the name (abbreviated) of the 15-minute quadrangle from which it was taken, the designation by number and letter of the particular 1-minute block in that quadrangle in which it was found, the geologic section in that block and the particular stratum in that

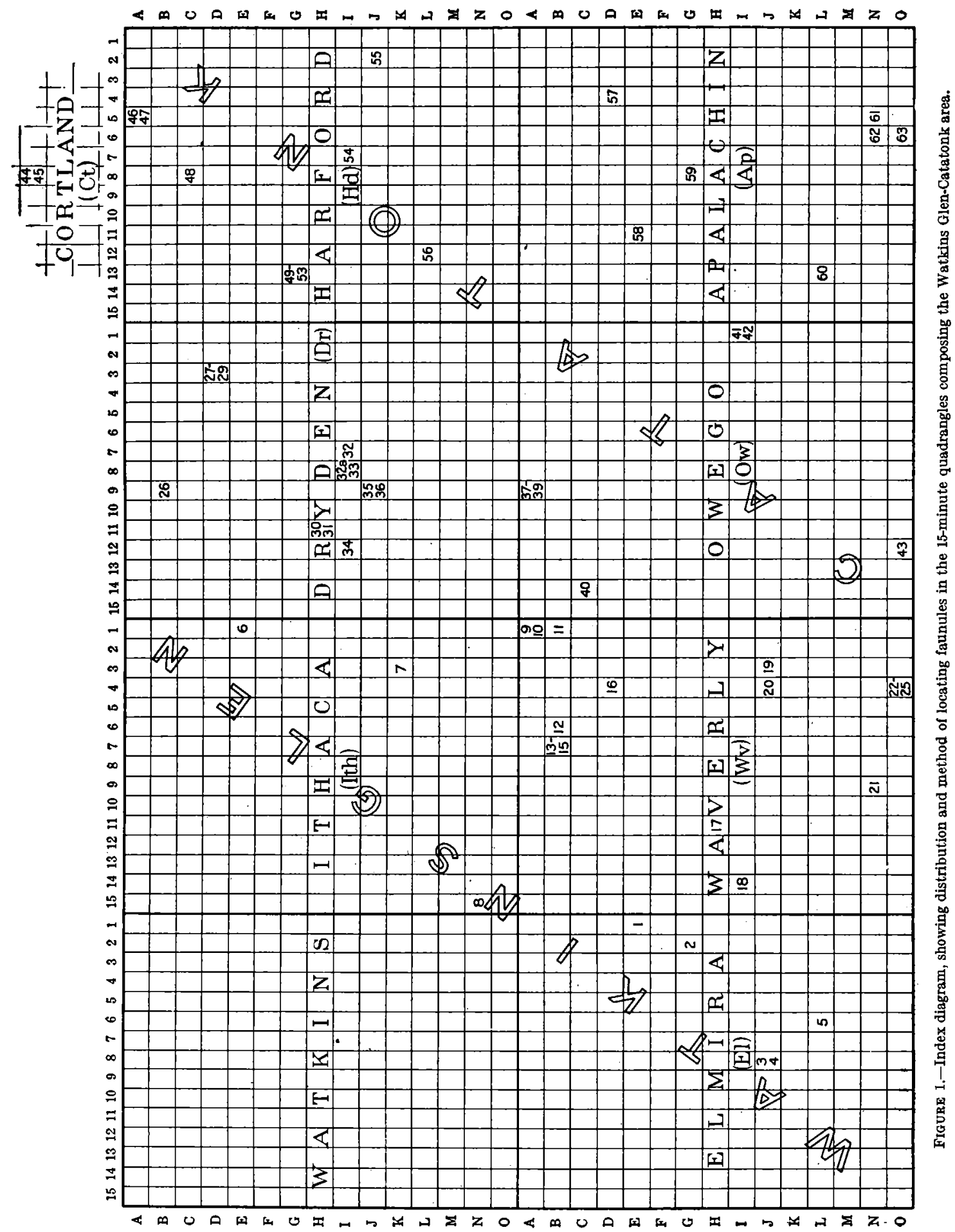

section as recorded on the field notebook record of the collector. The approximate altitude of the faunules above sea level and the zones which they are supposed to represent are also given. The altitudes were determined by means of the contours on the topographic atlas sheets and by measurements from the nearest bench mark, checked by aneroid barometer. 
Faunules of the recurrent Tropidoleptus fauna from the Watkins Glen and Catatonk 30-minute quadrangles. ${ }^{a}$

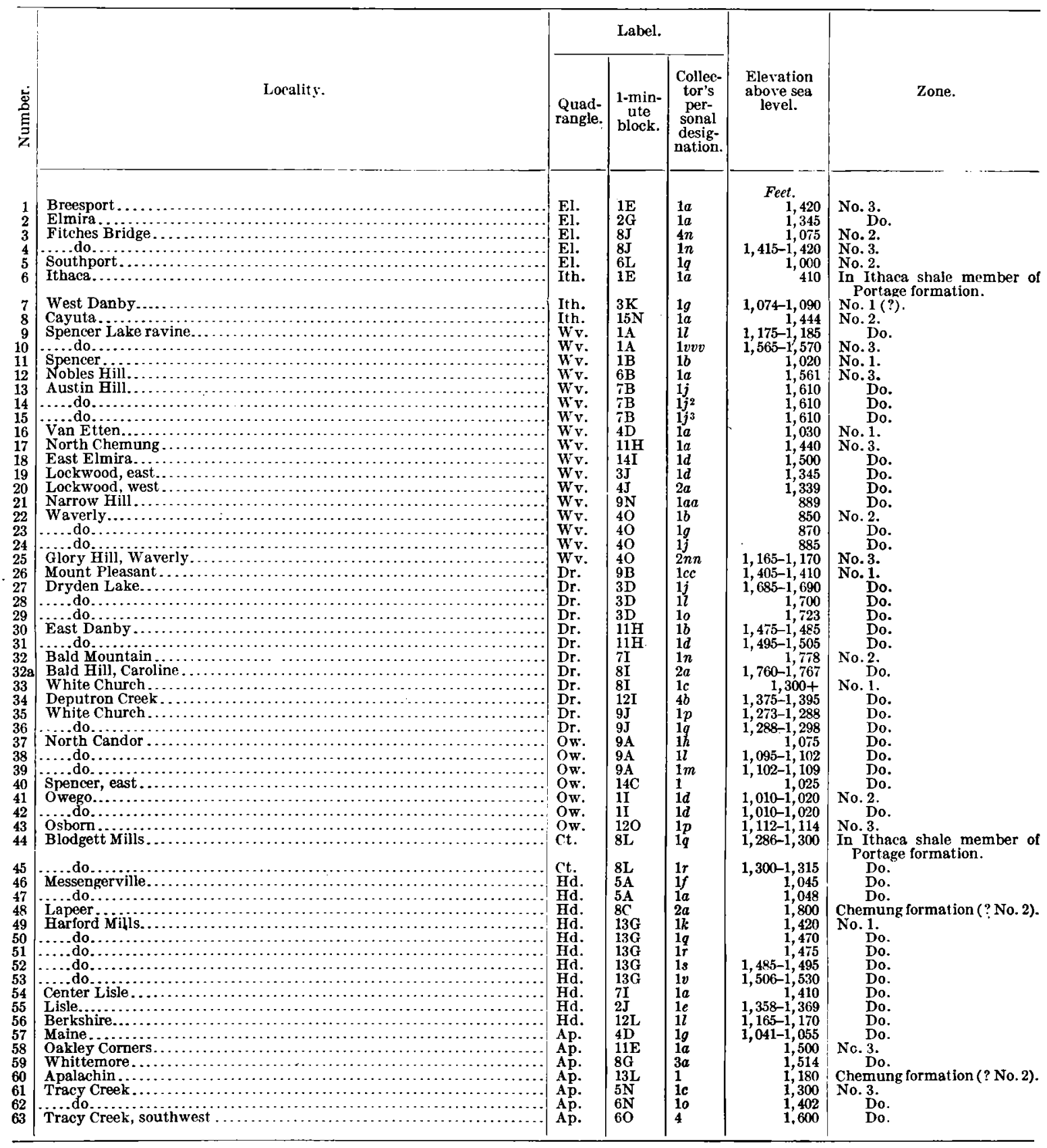

a Comprising the Watkins. Flmira (El.), Ithaca (Ith.), Waverly (Wv.), Dryden (Dr.), Owego (Ow.), Harford (Hd.), and Apalachin (Ap.) 15-minute quadrangles. Two faunules from the Cortland (Ct.) quadrangle, north of the Harford quadrangle, are included.

\section{FAUNAL LISTS.}

In the following lists are given the names of the chief species detected by a preliminary examination of the specimens as brought in from the field. There are, doubtless, many other outcrops in the region which, upon examination, might show expression of the same fauna. But the present set furnishes sufficient evidence to demonstrate the recurrence above the Hamilton formation of several zones, generally of very slight thickness, which contain representative species of the general Hamilton fauna, often in great numbers, but which contain fow of the species characteristic of the adjoining beds below and above the zones. 
Some of the lists do not include Tropidoleptus carinatus; these were included in the series because of the presence of one or more of the species commonly found associated with Tropidoleptus in the other samples, which gave ground for believing that in all probability further search will reveal Tropidoleptus also.

Each faunule has been studied and its species listed. In making up the lists the names applied have been those of the species already described in the literature with which the specimens more closely agree in their evident characters. Where the agreement is close the specific name is applied without comment; where variational modification is evident the fact is indicated by the prefix "cf." to the specific name; where the divergence is considerable the generic name alone is used without the specific name.

\section{FAUNAL LOCALITIES.}

1. Breesport.-One mile southwest of Breesport at forks of road; 3 or 4 feet of shaly sandstone; elevation, 1,420 feet above sea level (barometric). E. M. Kindle, collector, notebook, 1903, p. 70. Tropidoleptus zone No. 3 (Cayuta shale member). Fauna (El.1 E, 1a):

Rhipidomella vanuxemi.

Spirifer marcyi.

Schizophoria striatula.

Leiorhynchus sinuatum.

Camarotœchia sappho.

?Euomphalus.

Sphenotus sp.

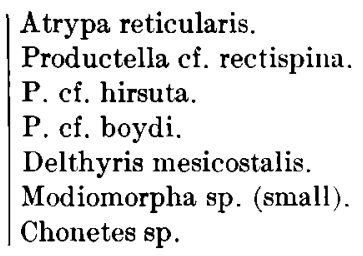

2. Elmira.-Quarry 2 miles northeast of Elmira at roadside east of the ravine entering Latty Brook from the northeast from the slopes of Maby Hill; shaly drab-colored sandstone and shale; elevation, 1,345 feet above sea level. E. M. Kindle, collector, 1903, p. 74. Tropidoleptus zone No. 3 (Cayuta shale member). Fauna (EI. 2G, 1a):

Tropidoleptus carinatus.

Rhipidomella vanuxemi.

Cypricardella bellistriata.

Delthyris mesicostalis.

Camarotœchia sappho.

Pleurotomaria cf. capillaria.

Leiorhynchus sinuatum.

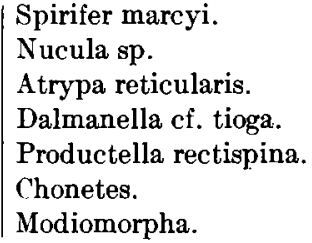

3. Fitches Bridge. - Section a mile west of Fitches Bridge, up the sides of the ravine; gray sandy shales and shaly sandstone; elevation, 1,075 feet above sea level (barometer). Original field No. $1172 \mathrm{~N}^{4}$. E. M. Kindle, collector, 1902, p. 17. Tropidoleptus zone No. 2 (Cayuta shale member). Fauna (El. 8J, 4n):

Rhipidomella vanuxemi. Cypricardella bellistriata. Leiorhynchus mesicostale. Atrypa reticularis. Camarotœchia cf. contracta. Delthyris mesicostalis. Palæoneilo bisulcata.

4. Fitches Bridge.-Section up ravine, a mile west of Fitches Bridge, upper part; elevation, 1,415-1,420 feet above sea level. V. H. Barnett, collector, notebook 1, p. 35. Tropidoleptus zone No. 3 (Cayuta shale member). Fauna (El. 8J, 1n):

Cypricardella bellistriata (small).

Delthyris mesicostalis.

Strophodonta (Donvillina) cayuta.

Schizophoria striatula.

Dalmanella tioga.

Atrypa reticularis.

Orbiculoidea elmira.

\author{
Ambocœlia umbonata (gregaria). \\ Modiomorpha neglecta. \\ M. cf. subalata. \\ Spathella sp.? \\ Palæoneilo bisulcata. \\ Macrodon chemungensis. \\ Productella lachrymosa.
}


5. Southport.-Quarry behind schoolhouse, 1 mile southwest of Southport (as given in notebook, 1902, p. 25); or, quarry $1 \frac{1}{2}$ miles west of Southport just south of schoolhouse (as given in notebook, 1903, p. 82); about 8 feet exposed, dipping $1^{\circ}$ to $2^{\circ} \mathrm{S}$. Some beds split into thin smooth-surfaced flakes, but most of them are of soft shaly sandstone that tend to break very irregularly when exposed to weather. Elevation not given; probably about 1,000 feet above sea level. Original mark 1172 Q. E. M. Kindle, collector, 1903, p. 82 . Tropidoleptus zone No. 2 (Cayuta shale member). Fauna ${ }^{1}$ (El. $\left.6 \mathrm{~L}, 1 q\right)$ :

Rhipidomella vanuxemi.

Schizophoria striatula.

Dalmanella tioga.

Leiorhynchus sinuatum.

Camarotœchia sappho.

Delthyris mesicostalis.

Atrypa reticularis.

Spirifer marcyi.

Schuchertella chemungensis.

Chonetes setigera.

Sphenotus sp.
Palæoneilo sp.
Nucula cf. corbuliformis.
Orbiculoidea elmira.
Leptodesma cf. agassizi.
Modiomorpha neglecta.
Pleurotomaria capillaria.
Bellerophon cf. leda.
Macrocheilina macrostoma.
Aviculopecten princeps.

6. Ithaca.-One mile south of Ithaca on the west side of Inlet Valley; elevation, approximately 410 feet above sea level. H. S. Williams, collector. Tropidoleptus zone of the Ithaca shale member. Fauna (Ith. $1 \mathrm{E}, 1 a$ ):

Rhipidomella vanuxemi.

Leiorhynchus mesicostale.

7. West Danby.-Section alongside hill and ravine west of village; lower part of the section; elevation, 1,074 to 1,090 feet above sea level. V. H. Barnett, collector, 1903, p. 56. Both above and below this zone the ordinary Portage fauna prevails, and about 150 feet above it the Dalmanella danbyi zone of the Chemung begins. Tropidoleptus zone No. 1 (Enfield shale member). Fauna (Ith. $3 \mathrm{~K}, 1 d, 1 e$, and $1 g$ ):

Delthyris mesicostalis.

Productella spinulicosta.

Chonetes sp.

Ambocœlia umbonata.

Pleurotomaria capillaria.

Bellerophon brevilineatus.

Palæoneilo brevis.

Leiorhynchus mesicostale.

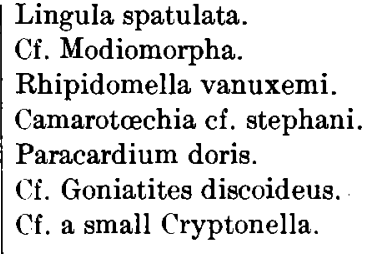

Still higher, at 1,410 feet above sea level (Ith. $3 \mathrm{~K}, 1 h \hbar h$ ) appears a trace of the Tropidoleptus zone No. 2, which is listed in the table of geographic distribution of Spirifer marcyi as No. $7 \mathrm{a}$. (See p. 63.)

8. Cayuta.-Hooker Creek, just below elbow west of Cayuta, near west edge of Ithaca quadrangle; 6 feet of soft sandstone and shale; elevation, approximately 1,444 feet above sea level. E. M. Kindle, collector, 1903, p. 30. Recurrent zone of doubtful horizon, probably No. 2. Fauna (Ith. 15N, 1a):

Rhipidomella vanuxemi.

Leiorhynchus sinuatum.

Productella cf. lachrymosa.
Orbiculoidea sp.

9. Spencer Lake ravine.-In deep gorge of stream running eastward and emptying into Spencer Lake; elevation, 1,175 to 1,185 feet above sea level. V. H. Barnett, collector, p. 51. Tropidoleptus zone No. 2 (Cayuta shale member). Fauna $^{2}$ (Wv. 1A, 1l):

Tropidoleptus carinatus.

Cf. Rhipidomella.
Leiorhynchus multicosta.

L. mesicostale.

\footnotetext{
1 I have not seen this fauna. The list of species was made out in the field by E. M. Kindle, who says in his notes: "Hamilton fauna abundant."

2 Twenty feet lower down in the section, in faunule Wv. 1A, 1h, Phacops rana appears with Spirifer marcyi. The latter species appears in several beds above the typical recurrent fauna (1l), ranging up to Wv. 1A, 1 , which is about 100 feet higher than $1 l$. See Spirifer marcyi (p. 63).
} 
Palæoneilo brevis. Ambocœlia umbonata. Spirifer ef. medialis. Schizophoria striatula. Productella cf. hirsuta. Pleurotomaria sp.

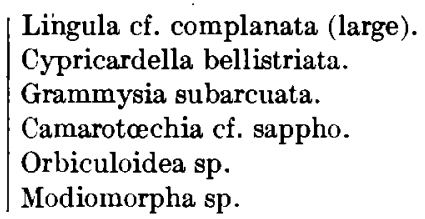

Lingula cf. complanata (large). Cypricardella bellistriata. Camarotochia cf. sappho. Modiomorpha sp.

10. Spencer Lake ravine.-Near top of ravine opening out to the east and running into Spencer Lake; elevation, 1,565 to 1,570 feet above sea level. V. H. Barnett, collector, p. 51. Tropidoleptus zone No. 3 (Cayuta shale member). Fauna (Wv. 1A, 1vvv):

Tropidoleptus carinatus. Rhipidomella vanuxemi. Delthyris mesicostalis.

Leiorhynchus sinuatum.

Schizophoria striatula.

Dalmanella carinata.

Schuchertella chemungensis.

Crania leoni.

Camarotœchia contracta.

C. sappho.

Atrypa reticularis (coarse variety).

Spirifer cf. medialis.

S. cf. macronotus.

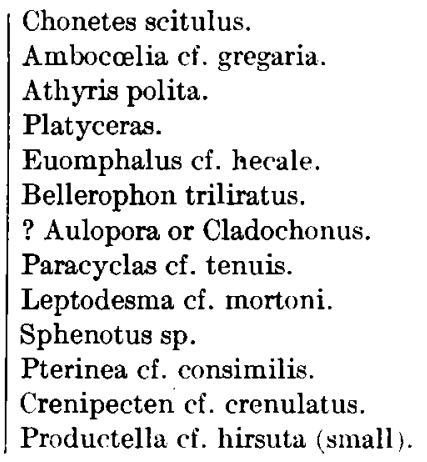

11. Spencer. - Section northwest of the Grove Hotel, Spencer, N. Y.; first outcrop in mouth of ravine; elevation, 1,020 feet above sea level. V. H. Barnett, collector, 1903, p. 56. Tropidoleptus zone No. 1 (Enfield shale member). Fauna (Wv. 1B, 1b):

Spirifer marcyi (high area and septum).

S. pennatus var.

Delthyris mesicostalis.

Cyrtina hamiltonensis.

Ambocœlia umbonata.

Atrypa reticularis.

Schizophoria striatula.

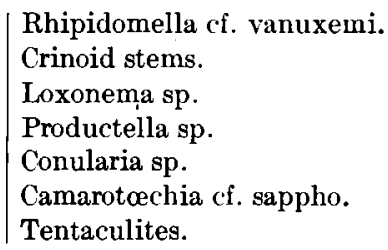

12. Nobles Hill.--Road running over the hill northward from the valley of Cayuta Creek across Nobles Hill, by the roadside, near boundary between blocks Wv. $6 \mathrm{~B}$ and Wv. $6 \mathrm{~A}$; hard coralline sandstone outcrops, above which the calcareous layers are leached out to form a brown "rotten stone;" elevation, 1,561 feet above sea level. C. L. Breger, collector, 1903, p. 29. Tropidoleptus zone No. 3 (Cayuta shale member). Fauna (Wv. 6B, 1a):

\begin{tabular}{l|l} 
Atrypa spinosa. & Aviculopecten cf. duplicatus. \\
Dalmanella tioga. & Pterinea cf. flabellum. \\
Schizophoria striatula. & Edmondia phillipi. \\
Strophodenta (Douvillina) cayuta. & Edmondia cf. sp. \\
Delthyris mesicostalis. & Leptodesma lichas. \\
Productella lachrymosa. & Leptodesma sp. \\
Ambocœlia umbonata gregaria. & Nucula umbonata. \\
Schuchertella chemungensis. & Tentaculites sp. \\
? Tropidoleptus carinatus (reported in the sandstone by & Monotrypa sp. \\
C. L. Breger but no specimen collected). & Rugose corals sp. \\
Pterinea cf. reversa. & Ceratopora chemungensis. \\
Glossites lingualis. & Fenestella sp. \\
Loxonema terebra. & Crinoid joints.
\end{tabular}

13. Austin Fill.--Side of road, running southwesterly from Swartwood near the summit of the hill; outcrop of hard sandstone bands, approximately 3 feet in thickness, 2 or 3 inches of each consisting of a mass of fossils; elevation, 1,610 feet above sea level. Original numbers 
7B, $1 j, 1 j^{2}, 1 j^{3}$. C. L. Breger, collector, 1903, pp. 25-26. Tropidoleptus zone No. 3 (Cayuta shale member). Fauna (Wv. 7B, $1 j)$ :

Tropidoleptus carinatus.

Rhipidomella vanuxemi.

Delthyris mesicostalis.

Cypricardella bellistriata.

Schizophoria striatula.

Dalmanella tioga.

Craniella hamiltoniæ.
Productella hirsuta.

Atrypa spinosa.

Camarotœchia cf. contracta.

Macrodon chemungensis.

Phthonia cylindrica.

Platyostoma lineata.

Monotrypella cf. furcata.

14. Austin Hill.-Southwest of Swartwood, top of hill, outcrop at roadside; elevation, 1,610 feet above sea level. C. L. Breger, collector, 1903, pp. 25-26. Tropidoleptus zone No. 3 (Cayuta shale member). Fauna (Wv. 7B, $1 j^{2}$ ):

Rhipidomella vanuxemi.

Spir.fer marcyi.

Delthyris mesicostalis.

Cypricardella bellistriata.

Dalmanella tioga.

Schizophoria striatula.

Camarotœechia cf. contracta.

Chonetes scitulus.

Craniella hamiltoniæ.

\author{
Atrypa spinosa. \\ Productella sp. lachrymosa. \\ Modiella pygmæa. \\ Modiomorpha mytiloides. \\ Pleurotomaria capillaria. \\ Platyostoma sp. \\ Loxonema sp. \\ Macrocheilina sp. \\ Leiorhynchus cf. sinuatum.
}

15. Austin Hill.-Near summit of hill southwest of Swartwood, alongside of road; elevation, 1,610 feet above sea level. C. L. Breger, collector, 1903, pp. 25-26. Tropidoleptus zone No. 3 (Cayuta shale member). Fauna (Wv. 7B, 1 $\left.j^{3}\right)$ :

Tropidoleptus carinatus.

Rhipidomella vanuxemi.

Spirifer marcyi.

Delthyris mesicostalis.

Cypricardella bellistriata.

Schizophoria striatula.

Chonetes scitulus.

Camarotœchia contracta.

Schuchertella chemungensis.

Modiomorpha cf. concentrica.

M. mytiloides.

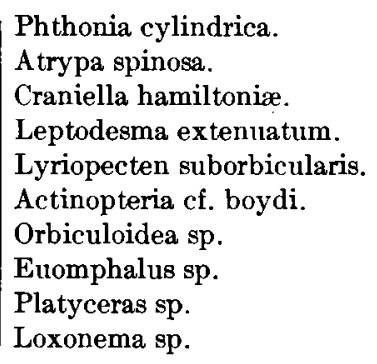

16. Van Etten. South of Van Etten station about half a mile, in stream running nearly north, east of main valley, in cliff on west side of stream at bridge; elevation, about 1,030 feet above sea level. H. S. Williams, collector, 1903, p. 9. Tropidoleptus zone No. 1 (Enfield shale member). Fauna ${ }^{1}$ (Wv. 4D, 1a):

Tropidoleptus carinatus. Spirifer marcyi.

Delthyris mesicostalis.

Rhipidomella vanuxemi.

Productella spinulicosta.

17. North Chemung.-About 200 yards north of forks of road, $1 \frac{1}{2}$ miles north of North Chemung; elevation, approximately 1,440 feet above sea level. E. M. Kindle, collector, 1903, notebook No. 2, p. 33 . Tropidoleptus zone No. 3 (Cayuta shale member). Fauna (Wv. $11 \mathrm{H}, 1 a)$ :

Rhipidomella vanuxemi. Delthyris mesicostalis. Spirifer marcyi. Cypricardella bellistriata.
Schizophoria striatula.

Camarotcechia cf. stephani.

Atrypa reticularis.

Dalmanella cf. carinata. 
18. East Elmira.-Outcrop along roadside below house at corner of road about 3 miles north of East Elmira, in about the middle of the section; thin-bedded sandstones weathering into small angular blocks; elevation, about 1,500 feet above sea level. E. M. Kindle, collector, 1903, notebook No. 2, p. 7. Tropidoleptus zone No. 3 (Cayuta shale member). Fauna (Wv. $14 \mathrm{I}, 1 d)$ :

Tropidoleptus carinatus. Rhipidomella vanuxemi. Cypricardella bellistriata. Spirifer marcyi.

Macrocheilina macrostoma.

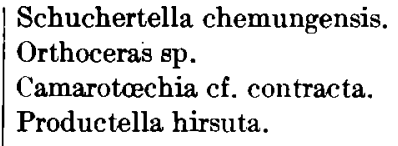

19. Lockwood, east.-Section alongside of road running up the side of the hill east of Lockwood station; hard calcareous stratum about 6 inches thick in the sandstone; the lower 3 inches is a "firestone," which contains many fossils; elevation, about 1,345 feet above sea level. C. L. Breger, collector, 1903, p. 42, Tropidoleptus zone No. 3 (Cayuta shale member). Fauna (Wv. 3J, 1d):

Tropidoleptus carinatus.

Spirifer marcyi.

Delthyris mesicostalis.

Cypricardella bellistriata.

Schizophoria striatula.

Chonetes scitulus.

Craniella hamiltoniæ.

Schuchertella chemungensis.

Productella lachrymosa.

\author{
Platyceras cf. erectum. \\ P. cf. conicum. \\ Macrocheilina sp. \\ Loxonema styliola. \\ Bellerophon pelops. \\ Platyostoma lineata. \\ Pleurotomaria capillaria. \\ Coleolus aciculum. \\ Crinoid joints.
}

20. Lockwood, west.-Hillside facing north, on south side of small west-east stream emptying into the main valley about a quarter of a mile south of Lockwood, on roadside; elevation, about 1,339 feet above sea level. C. L. Breger, collector, 1903, p. 41. Tropidoleptus zone No. 3 (Cayuta shale member). Fauna (Wv. 4J, 2a):

Tropidoleptus carinatus.

Spirifer marcyi.

Delthyris mesicostalis.

Cypricardella bellistriata.

C. gregaria.

Cyrtina hamiltonensis.

Schuchertella chemungensis.

Euomphalus hecale.

21. Narrow Hill.-In the midst of cliffs facing Chemung River at the southern end of Narrow Hill, at the southeastern corner of block $9 \mathrm{~N}, 1 \frac{1}{2}$ miles northwest of Chemung village. The upper part of the cliffs is composed of thick sandstones with thin shaly partings; at the top of these is the calcareous sandstone band containing the fossils here listed; elevation, approximately 890 feet above sea level. C. L. Breger, collector, 1903, p. 58. Tropidoleptus zone No. 3 (Cayuta shale member). Fauna (Wv. 9N, 1aa):

Tropidoleptus carinatus.

Spirifer marcyi.

Delthyris mesicostalis.

Rhipidomella vanuxemi.

Cypricardella bellistriata.

Chonetes scitulus.

Dalmanella tioga.

Camarotœchia sappho.
Bellerophon cf. pelops.

Schizophoria striatula.

Atrypa spinosa.

Camarotœchia sp.

Schizodus sp.

Murchisonia sp.

Pleurotomaria sp.

22. Waverly.-Cliff along north side of railroad tracks west of Waverly station, nearly opposite end of wagon bridge over Chemung River; band of sandy shales 4 inches thick; elevation, approximately 850 feet above sea level. E. M. Kindle, collector, 1903, notebook No. 2, 
p. 4; and detailed section, V. H. Barnett, collector, 1903, p. 37. Tropidoleptus zone No. 2 (Cayuta shale member). Fauna (Wv. 40, 1b):

Tropidoleptus carinatus.

Spirifer marcyi.

Delthyris mesicostalis.

Cypricardella bellistriata.

Leiorhynchus sinuatum.

\author{
Ambocœlia umbonata. \\ Dalmanella carinata. \\ Atrypa reticularis. \\ Camarotœchia cf. congregata. \\ Loxonema sp.
}

23. Waverly. - Cliff west of Waverly, north side of track, nearly opposite wagon bridge; $1 g$ about 20 feet higher in the section than $1 b$ (faunule 22 ); and $1 h, 5$ feet still higher; elevation, 870 and 875 feet above sea level. V. H. Barnett, collector, 1903, p. 37. Tropidoleptus zone No. 2 (Cayuta shale member). Fauna (Wv. 4O, $1 g, 1 h$ ):

Cypricardella bellistriata.

Delthyris mesicostalis.

Rhipidomella vanuxemi.

Productella lachrymosa.

Camarotœchia cf. congregata.

\author{
Ambocœlia umbonata. \\ Orbiculoidea sp. \\ Chonetes sp. \\ Leiorhynchus cf. sinuatum.
}

24. Waverly.-Cliff west of Waverly, 10 feet higher than $1 h$; shaly sandstone stratum $1 j$; elevation approximately 885 feet above sea level. V. H. Barnett, collector, 1903, p. 37. Tropidoleptus zone No. 2 (Cayuta shale member). Fauna ${ }^{1}$ (Wv. 4O, 1j):

Tropidoleptus carinatus.

Rhipidomella vanuxemi.

Spirifer marcyi.

Delthyris mesicostalis.

Cypricardella bellistriata.

Ambocœlia umbonata.

Schizophoria striatula.

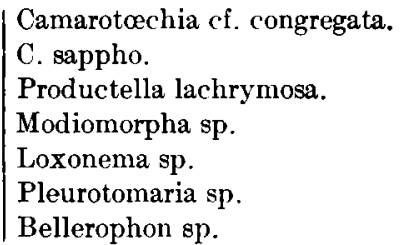

25. Glory Hill, Waverly.-Quarry on the southeast slope of Glory Hill, about 2 miles west of Waverly, near the top of the quarry; calcareous band of sandstone, filled with fossils; elevation, 1,165 to 1,170 feet above sea level. (Original label " $b$ 40.") V. H. Barnett, collector, 1903, p. 38. Tropidoleptus zone No. 3 (Cayuta shale member). Fauna ${ }^{2}$ (Wv. 4O, 2nn):

Tropidoleptus carinatus.

Delthyris mesicostalis.

Spirifer marcyi.

Schizophoria striatula.

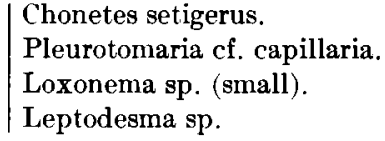

26. Mount Pleasant.-Ravine south of Etna, running down northern face of Mount Pleasant; thin-bedded sandy shales containing the recurrent fauna; elevation, 1,405 to 1,410 feet above sea level. V. H. Barnett, collector, 1903, p. 8. Tropidoleptus zone No. 1 (Enfield shale member). Fauna (Dr. 9B, 1cc):

Rhipidomella vanuxemi.

Spirifer marcyi.

S. cf. pennatus.

Cyrtina hamiltonensis.

Lingula sp.

Chonetes scitulus.

Schizophoria striatula.

27-29. Dryden Lake.-Upper part of the small stream groove running down the eastern face of the high hills to the west of Dryden Lake, northeast corner of block 3D; outcrops containing traces of the recurrent fauna. Elevation about 1,685 to 1,690 feet above sea level ( $1 j$ ); 10 feet higher (1l); and 1,723 feet (1o). V. H. Barnett, collector, 1903.

\footnotetext{
1 Five feet still higher in the section Snirifer fimbriatus was found with Dalmanella carinala, Spirifer marcyi, and other species.

2 In a loose fragment in bed of quarry, of the same character of rock and containing Tropidoleptus, I found a fragment of a fish bone. The bone fragment is over half an inch thick, 2 inches by $1 \frac{1}{2}$ Inches across, and is evidently part of a bone which was originally of large dimensions.
} 
27. Tropidoleptus zone No. 1 (Enfield shale member). Fauna (Dr. 3D, 1j):

Tropidoleptus carinatus.

Rhipidomella vanuxemi.
Chonetes cf. scitulus.

Ambocœlia umbonata.

28. Tropidoleptus zone No. 1 (Enfield shale member). Fauna (Dr. 3D, 1l):

Tropidoleptus carinatus.

Rhipidomella vanuxemi.

Delthyris mesicostalis.

Productella spinulicosta.

Chonetes cf. scitulus.

('amarotœchia cf. eximia.

Ambocœlia umbonata.

Grammysia sp.

Leiopteria sp.

A viculopecten sp.

29. Tropidoleptus zone No. 1 (Enfield shale member). Fauna (Dr. 3D, 1o):

Tropidoleptus carinatus.

Rhipidomella vanuxemi.

Delthyris mesicostalis.

Spirifer marcyi.

Productella spinulicosta.

Atrypa reticularis.

Palæoneilo cf. brevis.

A viculopecten sp.

Pleurotomaria sp.

30-31. East Danby.-About $1 \frac{1}{2}$ miles west of the Caroline junction of the Lehigh Valley and Delaware, Lackawanna \& Western railroads, in the upper part of the small stream cutting easterly down the hillside; outcrop, 16 , at elevation of 1,475 to 1,485 feet above sea level; and $1 d$, at elevation of 1,495 to 1,505 feet. C. L. Breger, collector. Tropidoleptus zone No. 1 (Enfield shale member). Fauna (Dr. $11 \mathrm{H}, 1 b, 1 d)$ :

Tropidoleptus carinatus.

Rhipidomella vanuxemi.

Delthyris mesicostalis.

Spirifer fimbriatus.

Phacops rana.

Camarotcechia sp.

Leiorhynchus mesicostale.

Leptodesma sp.

Modiomorpha sp.

Schuchertella chemungensis.

Productella sp.

Ambocœlia umbonata.

Palæoneilo sp. cf. brevis.

32. Bald Mountain.-Middle summit, upper part of section running up the stream valley which cuts the east side of the hill and empties into the valley about 3 miles south of Slaterville, near summit of hill; elevation, 1,778 feet above sea level. V. H. Barnett, collector, 1903, p. 15. Tropidoleptus zone No. 2 (Cayuta shale member). Fauna (Dr. 8I, 1n, not Dr. $7 \mathrm{I}, 1 n$, as label indicates):

Tropidoleptus carinatus.

Rhipidomella vanuxemi.

Delthyris mesicostalis.

Spirifer marcyi.

Cypricardella bellistriata.

Orbiculoidea sp.

Lingula cf. complanata.

$\mid \begin{aligned} & \text { Schizophoria striatula. } \\ & \text { Dalmanella tioga. } \\ & \text { Camarotœchia sappho. } \\ & \text { Atrypa spinosa. } \\ & \text { Ambocelia umbonata. } \\ & \text { Cf. Lyriopecten. } \\ & \text { Modiomorpha sp. }\end{aligned}$

32a. Bald Hill, Caroline.-Bed of road running north and south, in the southeast quarter of block Dr. 8I; outcrop ${ }^{1}$ of 7 to 8 feet of flaggy sandstones, in the lower part of which the Tropidoleptus fauna appears; elevation, 1,760 to 1,767 feet above sea. C. L. Breger, collector, 1905, p. 84. Tropidoleptus zone No. 2 (Enfield shale member). Fauna (Dr. 8I, 2a):

Tropidoleptus carinatus.

Delthyris mesicostalis.

Rhipidomella vanuxemi.

Spirifer marcyi.

Dalmanella tioga.

Ambocœlia umbonata.

Productella cf. spinulicosta

P. cf. hirsuta.

Schizophoria striatula.

Chonetes scitulus.

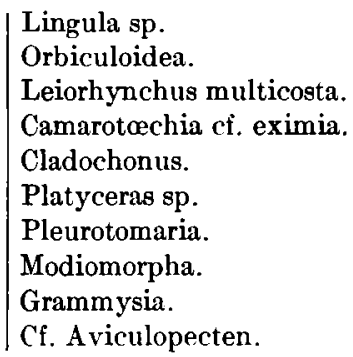

1 This is probably the same outcrop discovered by V. H. Barnett (Dr. $i \mathrm{I}, 1 n$ ). For the purposes of this paper the two will be considered under the one sample No. 32.

$67437^{\circ}-$ No. $79-13-2$ 
33. White Church.-About halfway up the stream valley cutting the hillside north of White Church; shales and shaly thin-bedded sandstones outcropping below and above the second bridge; elevation, 1,298 to 1,314 feet above sea level. C. L. Breger, collector, 1905, p. 81. Tropidoleptus zone No. 1 (Enfield shale member). Fauna (Dr. 8I, 1c):

Tropidoleptus carinatus.

Rhipidomella vanuxemi.

Spirifer marcyi.

Delthyris mesicostalis.

Phacops rana.

Coleolus aciculum

Pleurotomaria capillaria.

Ambocœlia umbonata.

Orbiculoidea.

Leiorhynchus cf. multicosta.

Camarotœchia sp.

Chonetes.

Productella spinulicosta.

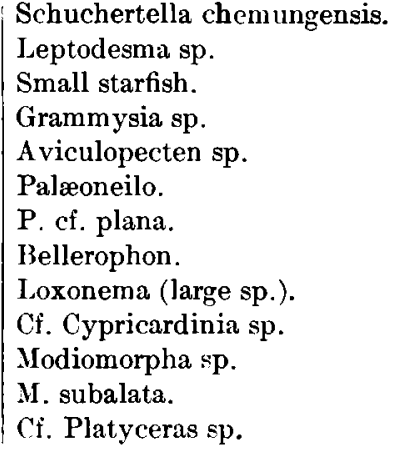

34. Deputron Creek.-Deputron Creek, running down the eastern face of the hills opposito Caroline Depot, near the southern border of block 11H; several outcrops (field labels Dr. 11I, $1 b$; Dr. 11I, 1c) of a coarse blocky sandstone and shales containing traces of the recurrent fauna; elevation, 1,375 to 1,395 feet above sea level. C. L. Breger, collector, 1905, p. 89 . Tropidoleptus zone No. 1 (Enfield shale member). Fauna (Dr. 12I, 4b):

Tropidoleptus carinatus.

Rhipidomella vanuxemi.

Spirifer marcyi.

Delthyris mesicostalis.

Ambocœlia umbonata.

Schizophoria striatula.

Productella cf. lachrymosa stigmata.

P. cf. spinulicosta.

Camarotœchia cf. contracta.

Chonetes scitulus.

Orbiculoidea.

Cyrtina hamiltonensis.

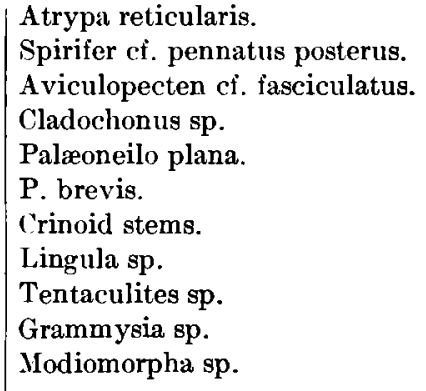

35-96. White Church.-Same section as faunule 33. Collected by V. H. Barnett, 1903, notebook, p. 25; elevation 1,273 to 1,288 feet $(1 p)$ and 1,288 to 1,298 ( $1 g$ ) above sea level (reported under field label Dr. 8I, 1c):

35. Tropidoleptus zone No. 1 (Enfield shale member). Fauna (Dr. 9J, 1p):

Tropidoleptus carinatus.

Rhipidomella vanuxemi.

Chonetes setigera-scitulus.

Productella cf. spinulicosta.

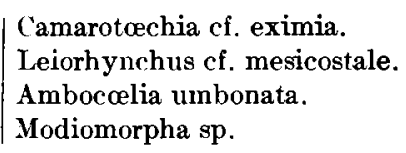

36. Tropidoleptus zone No. 1 (Enfield shale member). Fauna (Dr. 9J, 1q):

Tropidoleptus carinatus.

Rhipidomella vanuxemi.

Productella cf. spinulicosta.

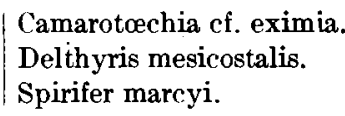

The fauna containing Spirifer marcyi (see p. 63, under symbol Dr. $11 \mathrm{~K}, 1$ E.M.K.) is in an outcrop on the other side of the valley on the side of Eastman Hill, and belongs to the same zone. It may be numbered $36 a$.

37-39. North Candor.- Section begins at the first outcrop of sandy shale in a small stream on the north side of wagon road, situated in the southwest corner of block $9 \mathrm{~A}$, at an elevation of about 1,040 feet above sea level and follows up the hill toward the north. The zones from which the recurrent fauna come are $1 h$ at 1,075 feet, $1 l$ at 1,095 to 1,102 feet, and $1 m$ at 1,102 to 1,109 feet above sea level. V. H. Barnett, collector, 1903, notebook No. 2, p. 64. 
37. Tropidoleptus zone No. 1 (Enfield shale member). Fauna (Ow. 9A, 1h):

Rhipidomella vanuxemi.

Delthyris mesicostalis.

Ambocœlia umbonata.

\author{
Camarotœchia sappho. \\ Leptodesma sp. \\ Modiomorpha sp.
}

38. Tropidoleptus zone No. 1 (Enfield shale member). Fauna (Ow. 9A 1l):

Tropidoleptus carinatus. Rhipidomella vanuxemi. Delthyris mesicostalis. Spirifer marcyi.

Productella spinulicosta. Chonetes.

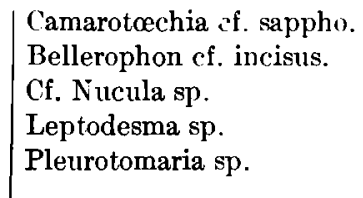

39. Tropidoleptus zone No. 1 (Enfield shale member). Fauna (Ow. 9A, $1 \mathrm{~m}$ ):

Tropidoleptus carinatus. Rhipidomella vanuxemi. Delthyris mesicostalis. Spirifer marcyi.

Camarotøechia sappho.

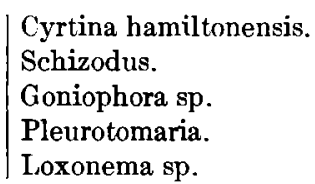

40. Spencer, east.-Mouth of small ravine one-half mile east of Spencer, outcrop of shaly sandstones containing the recurrent fauna; elevation, 1,025 feet above sea level. E. M. Kindle, collector, 1904, notebook No. 2, p. 17. Tropidoleptus zone No. 1 (Enfield shale member). Fauna (Ow. 14C, 1):

Tropidoleptus carinatus. Spirifer marcyi.

Delthyris mesicostalis.

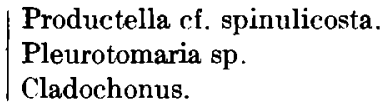

41. Owego, north. - Quarry north side of Owego on Cemetery Hill; middle of quarry face; elevation, slightly more than 1,000 feet above sea level $(1,010$ to 1,020 feet $)$. V. H. Barnett, collector, 1904, p. 34. Tropidoleptus zone No. 2 (Cayuta shale member). Fauna (Ow. 1I, 1d):

Tropidoleptus carinatus.

Spirifer marcyi.

Cypricardella bellistriata.

Modiomorpha sp.

Ambocœlia umbonata.

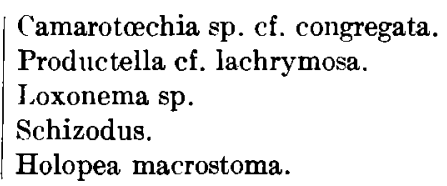

A faunule ( $1 f$ ) about 10 feet above No. 41 contains, in addition, Rhipidomella vanuxemi. Lower down in the quarry, at an altitude of 980 feet above sea level a specimen of Spirifer disjunctus was found, showing definitely the position of the zone in the section. This is the original locality of the Tropidoleptus zone described later as the recurrent Tropidoleptus fauna from Cemetery Hill, Owego, Tioga County. ${ }^{1}$

42. Owego, north.-Quarry in northern part of Owego on the southerly slope of Cemetery Hill. Same locality as faunule 41. Cornell University Museum, L. Reinecke, collector, 1904, notebook, pp. 60, 61. Tropidoleptus zone No. 2 (Cayuta shale member). Fauna (Ow. 1I, 1d):

Tropidoleptus carinatus. Spirifer marcyi. Delthyris mesicostalis. Cypricardella bellistriata. Phacops rana.

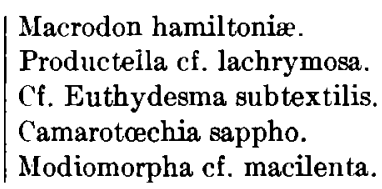

43. Osborn.-Section begins in the first outcrops of rock in the stream valley east of Osborn, and runs up into the hill to the east. The recurrent fauna appears on the west side of block 
120; elevation, 1,112 to 1,114 feet above sea level. V. H. Barnett, collector, 1904, pp. 68, 69 . Tropidoleptus zone No. 3 (Cayuta shale member). Fauna (Ow. 12O, $1 p$ ):

Tropidoleptus carinatus.

Delthyris mesicostalis.

Spirifer ef. marcyi.

Cypricardella bellistriata.

Leiopteria cf. mitchelli.

Chonetes scitulus.

Leptodesma cf. lichas.

Palæoneilo cf. plana.

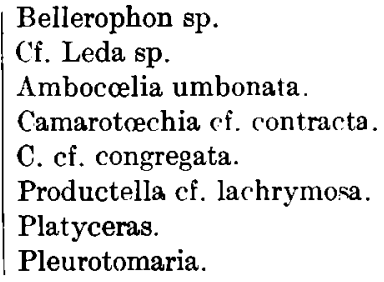

44. Blodgett Mills. - Section in first creek south of Blodgett Mills running into the Tioughnioga from the west; elevation, between 1,286 and 1,300 feet above sea level. L. Reinecke, collector, 1904, pp. 53, 54. Tropidoleptus zone in the Ithaca shale member. Fauna (Ct. $8 \mathrm{~L}, 1 q)$ :

Tropidoleptus carinatus.

Cypricardella bellistriata.

Spirifer mesistrialis.

S. pennatus posterus.

Chonetes scitulus.

C. deflectus.

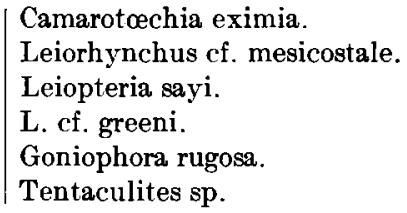

45. Blodgett Mills.-Massive light-gray sandstones, resting on the sandstones described in faunule 44; elevation, approximately 1,300 to 1,315 feet above sea level. L. Reinecke, collector, 1904, p. 53. Tropidoleptus zone in the Ithaca shale member. Fauna (Ct. 8L, 1r):

Tropidoleptus carinatus.

Cypricardella bellistriata.

Spirifer mesistrialis.

S. pennatus.

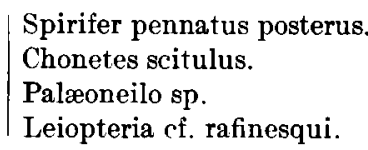

46. Messengerville.-Bridge over Tioughnioga River; elevation, about 1,045 feet above sea level. V.H. Barnett, collector, 1904, p. 7. Tropidoleptus zone in the Ithaca shale member. Fauna (Hd. 5A, 1f):

Tropidoleptus carinatus.

Spirifer mesistrialis.

Delthyris cf. consobrinus.

Cyrtina hamiltonensis.

Productella sp. spinulicosta.

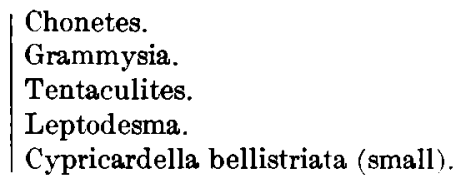

47. Messengerville.-Section beginning at Hd. 5A, $1 a$, just below the bridge over Tioughnioga River east of Delaware, Lackawanna \& Western tracks, and running upward through East Virgil and Messengerville; elevation (barometric), 1,048 feet above sea level. L. Reinecke, collector, 1904, p. 50. Tropidoleptus zone in the Ithaca shale member. Fauna (Hd. 5A, 1a):

Tropidoleptus carinatus.

Cypricardella bellistriata.

Spirifer mesistrialis.

S. pennatus posterus (small).

Leptodesma small sp.

Modiomorpha cf. concentrica.

48. Lapeer.-Summit of road running northwest from Lapeer; elevation, approximately 1,800 feet above sea level. E. M. Kindle, collector, 1904, p. 53. Tropidoleptus zone No. 2 ?, in Chemung formation. Fauna (Hd. 8C, 2a):

Tropidoleptus carinatus.

Cf. Delthyris mesicostalis.

Camarotœchia sp.

Leptodesma.

Crenipecten.

Productella sp.

Ambocœlia umbonata.

This fauna is within the zone which on lithologic evidence has been mapped as Chemung, but on account of the scantiness of the fossils discovered in the neighborhood its exact position 
in the series is not certain. For purposes of discussion I class it with the Tropidoleptus zone No. $2(\hat{\imath})$.

49-53. Harford Mills.- Section begins at mouth of gorge opening into the east branch of Owego Creek $1 \frac{1}{2}$ miles southeast of Harford Mills; outcrops containing Tropidoleptus are at elevations of $1,420(1 k), 1,470(1 q), 1,475(1 r), 1,485$ to $1,495(1 s)$, and 1,506 to $1,530(1 v)$ feet above sea. L. Reinecke, collector, 1904, p. 27.

49. Tropidoleptus zone No. 1 (Enfield shale member). Fauna (Hd. 13G, 1k):

Cf. Tropidoleptus carinatus.

Camarotœchia cf. sappho.

Delthyris mesicostalis.

50. Tropidoleptus zone No. 1 (Enfield shale member). Fauna (Hd. 13G, 1q):

Tropidoleptus carinatus.

Delthyris mesicostalis.

Schuchertella chemungensis.

Chonetes scitulus.

Ambocœlia umbonata.

Camarotœchia cf. sappho.

Leptodesma cf. lichas.

L. cf. potens.

51. Tropidoleptus zone No. 1 (Enfield shale member). Fauna (Hd. 13G, 1r):

Camarotœchia cf. sappho.

Cf. Delthyris mesicostalis.

Cf. Tropidoleptus carinatus.

52. Tropidoleptus zone No. 1 (Enfield shale member). Fauna (Hd. 13G, 1s):

Tropidoleptus carinatus.

Rhipidomella vanuxemi.

Delthyris mesicostalis.

Camarotochia cf. contracta.

Atrypa reticularis (large).

Modiomorpha mytiloides.

Leiopteria cf. rafinesqui.

Limoptera macroptera (small).

Crinoid joints.

53. Tropidoleptus zone No. 1 (Enfield shale member). Fauna ${ }^{1}$ (Hd. 13G, 1v):

Tropidoleptus carinatus.

Delthyris mesicostalis.

Cypricardella bellistriata.

Rhipidomella vanuxemi.

Spirifer marcyi.

Camarotœchia sappho.

Chonetes scitulus.

Spirifer cf. pennatus.

Craniella hamiltoniæ.
Leptodesma cf. lichas.
L. cf. creon.
Leiopteria cf. conradi.
L. cf. rafinesqui.
Glyptodesma erectum.
A viculopecten cf. princeps.
Grammysia subarcuata.

54. Center Lisle.-East-west road, about 2 miles west of Center Lisle, near the western boundary line of Broome County; 40 to 50 feet of drab sandstone; elevation, 1,410 feet above sea level. E. M. Kindle, collector, 1904, p. 61. Tropidoleptus zone No. 1 (Enfield shale member). Fauna (Hd. 7I, 1a):

Tropidoleptus carinatus.

Rhipidomella vanuxemi.

Delthyris mesicostalis.

Ambocoelia umbonata.

55. Lisle. Section up hillside sloping northward along north-south road in middle of block 2J. Elevation of Tropidoleptus zone, about 1,350 feet above sea level. L. Reinecke, collector, 1904, pp. 55 and 56. Also E. M. Kindle, collector, 1904, p. 92. Tropidoleptus zone No. 1 (Enfield shale member). Fauna ${ }^{2}$ (Hd. 2J, 1e):

Rhipidomella vanuxemi.

Tropidoleptus carinatus.

Cypricardella bellistriata.

Camarotœchia cf. eximia.

C. cf. sappho.

Chonetes sp.

(yrtina hamiltonensis.

Modiomorpha sp.

? Fish plate.

${ }^{1}$ The field label for this fauna appears to be IId. 13G, $1 v$; from the fullness of the fauna it is thought possible that the letter $r$ has been mistaken for $v$ and that 51 and 53 should be transposed.

2A few feet higher Spirifer marcyi and Rhipidomella occur at 1,305 to 1,316 feet. In the same fauna is seen Spirifer marcyi with a rudimentary syrinx and Rhipidomella vanuremi. 
56. Berkshire.-Ravine west of village of Berkshire; 15 feet of grayish-blue sandy shale; elevation, 1,165 to 1,170 feet above sea level. V. H. Barnett, collector, 1904, notebook No. 2, p. 19. Tropidoleptus zone No. 1 (Enfield shale member). Fauna (Hd. 12L, 1l):

Tropidoleptus carinatus.

Rhipidomella vanuxemi.

Spirifer cf. marcyi.

Delthyris mesicostalis.

Productella cf. spinulicosta.

Lingula complanata.

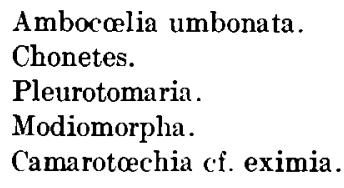

57. Maine.-Section begins in the foot of the ravine opening into Nanticoke Creek east and a little south of the center of village of Maine; elevation, 1,041 to 1,055 feet above sea level. L. Reinecke, collector, 1904, p. 57. Tropidoleptus zone No. 1 (Enfield shale member). Fauna (Ap. 4D, 1g):

Tropidoleptus carinatus.

Delthyris mesicostalis.

Spirifer cf. pennatus.

Camarotœchia cf. sappho.
Ambocœlia gregaria .

Leptodesma potens.

Edmondia cf. philippi.

58. Oakley Corners.-Road running west from Oakley Corners, eastern side of block 11E; about 30 feet of shaly sandstones containing Tropidoleptus; elevation, 1,500 feet above sea level. E. M. Kindle, collector, 1904, p. 27. Tropidoleptus zone No. 3 (Cayuta shale member). Fauna (Ap. 11E, 1a):

Tropidoleptus carinatus.

Spirifer fimbriatus.

S. marcyi.

Rhipidomella vanuxemi.

Delthyris mesicostalis.

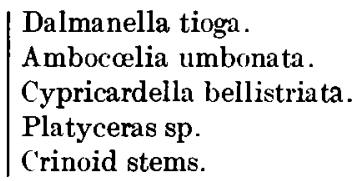

59. Whittemore.-Summit of hill marked 1514 on Apalachin topographic sheet, in the northern part of block $8 \mathrm{G}$, in the road opposite a house; 2 feet of shaly sandstones containing Tropidoleptus; elevation, 1,514 feet above sea level. E. M. Kindle, collector, p. 27. Tropidoleptus zone No. 3 (Cayuta shale member). Fauna (Ap. 8G, 3a):

Tropidoleptus carinatus.

Spirifer marcyi.

Rhipidomella vanuxemi.

Delthyris mesicostalis.

Cypricardella cf. bellistriata.

Dalmanella sp.

Chonetes sp.

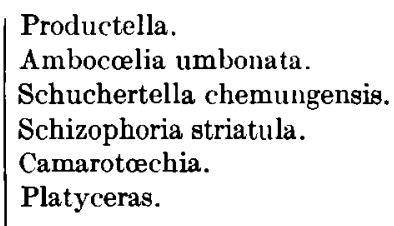

60. Apalachin.-Road running south from Hiawatha Island up the hill, in the north edge of block 13L; a calcareous band 6 inches thick, containing Tropidoleptus; elevation, 1,180 feet above sea level. E. M. Kindle, collector, 1904, p. 91. Tropidoleptus zone No. 2, Chemung formation. Fauna (Ap. 13L, 1):

Tropidoleptus carinatus.

Cf. Delthyris mesicostalis.

Spirifer marcyi.

Ambocolia umbonata.

The failure to discover in this general area fossils that mark the boundaries of the range of the Chemung fauna leaves doubt as to the actual horizon of this fauna. It is clearly above the base of the Chemung and there are recurrent faunas at a level stratigraphically higher. I have therefore listed it as probably belonging in Tropidoleptus zone No. 2.

61. Tracy Creek.-Section along road ascending hill west of Tracy Creek village. Hard calcareous sandstone weathering to brown rotten stone containing Tropidoleptus; elevation, 
1,300 feet above sea level. T. H. Barnett, collector, 1904, p. 26. Tropidoleptus zone No. 3 (Cayuta shale member). Fauna (Ap. 5N, 1c):

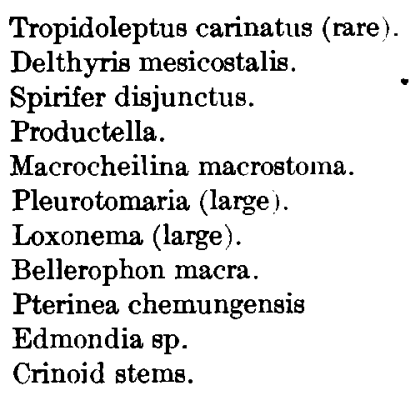

62. Tracy Creek.-Same section as faunule 61 , but higher; calcareous sandstones with Tropidoleptus; elevation, about 1,402 feet above sea level. V.H. Barnett, collector, 1904, p. 27. Tropidoleptus zone No. 3 (Cayutal shale member). Fauna (Ap. 6N, 10):

Tropidoleptus carinatus.

Spirifer cf. pennatus.

Chonetes.

63. Tracy Creek, southwest.-Northwest corner of block 6O, 200 to 300 yards southwest of forks of road. A loose block of blackish ferruginous mass holding numerous specimens of Tropidoleptus, with flat pebble conglomerate; elevation, 1,600 feet above sea level. E. M. Kindle, collector, 1904, p. 85. Tropidoleptus zone No. 3 (Cayuta shale member). Fauna (Ap. 6O, 4):

Tropidoleptus carinatus.

Bellerophon.

Spirifer fragments.

Chonetes sp.

\section{THE RECURRENT ZONES.}

\section{STRATIGRAPHIC POSITIONS.}

The several recurrent faunules here considered were taken from certain definite positions in the stratigraphic sequence, not lower than the Ithaca member of the Portage formation and not higher than the top of the Cayuta member of the Chemung formation. Each individual faunule is limited in range to a few feet and in many places to a few inches of thickness of strata; the composition of the faunas both below and above in many sections shows a strong contrast to the specific composition of the particular faunule listed. On tabulating the sections the individual faunules

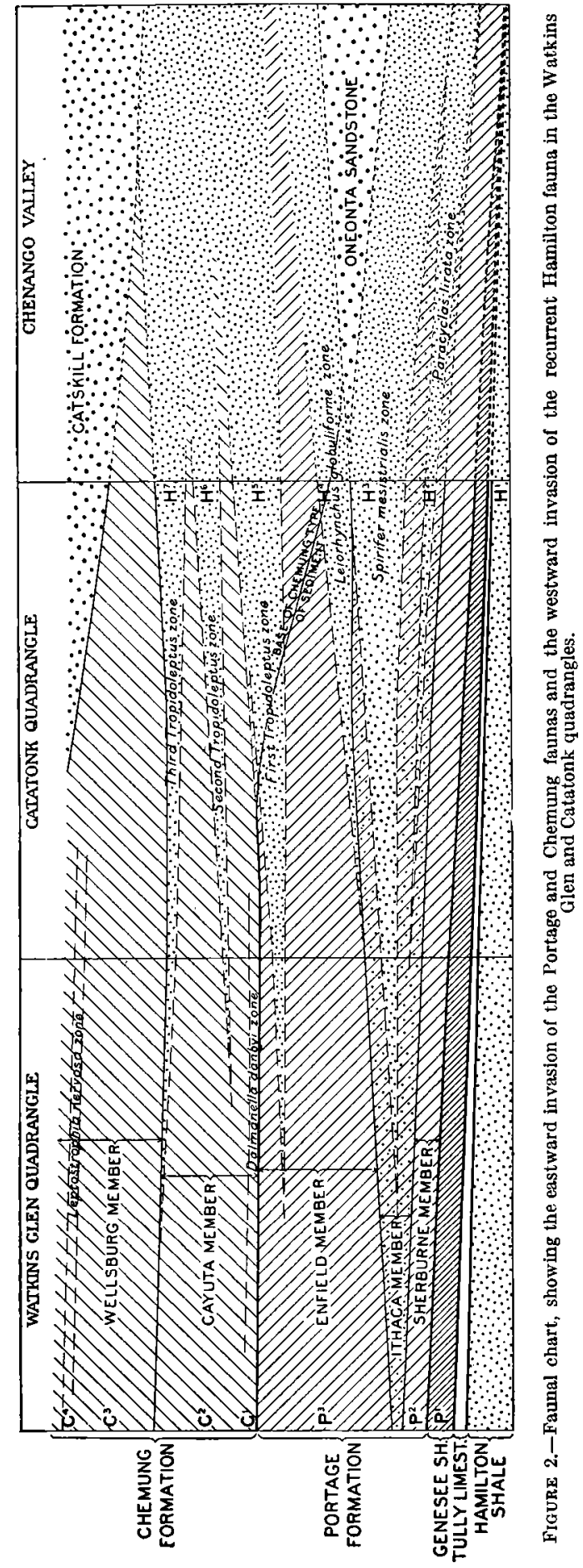

1. The Tropidoleptus zone of the Ithaca shale member. In the lower part of the Portage formation not over 50 feet above the base of the Ithaca member.

2. The Tropidoleptus zone No. 1. In the upper part of the Portage, within the uppermost 200 feet of the Enfield shale member. Represented there by several successive individual' 
faunules, ranging through nearly 100 vertical feet in some of the more eastern sections but restricted to narrower limits in the more western sections.

3. The Tropidoleptus zone No. 2. In the lower third of the Cayuta shale member of the Chemung formation, near the horizon where the Chemung fauna has first reached its full

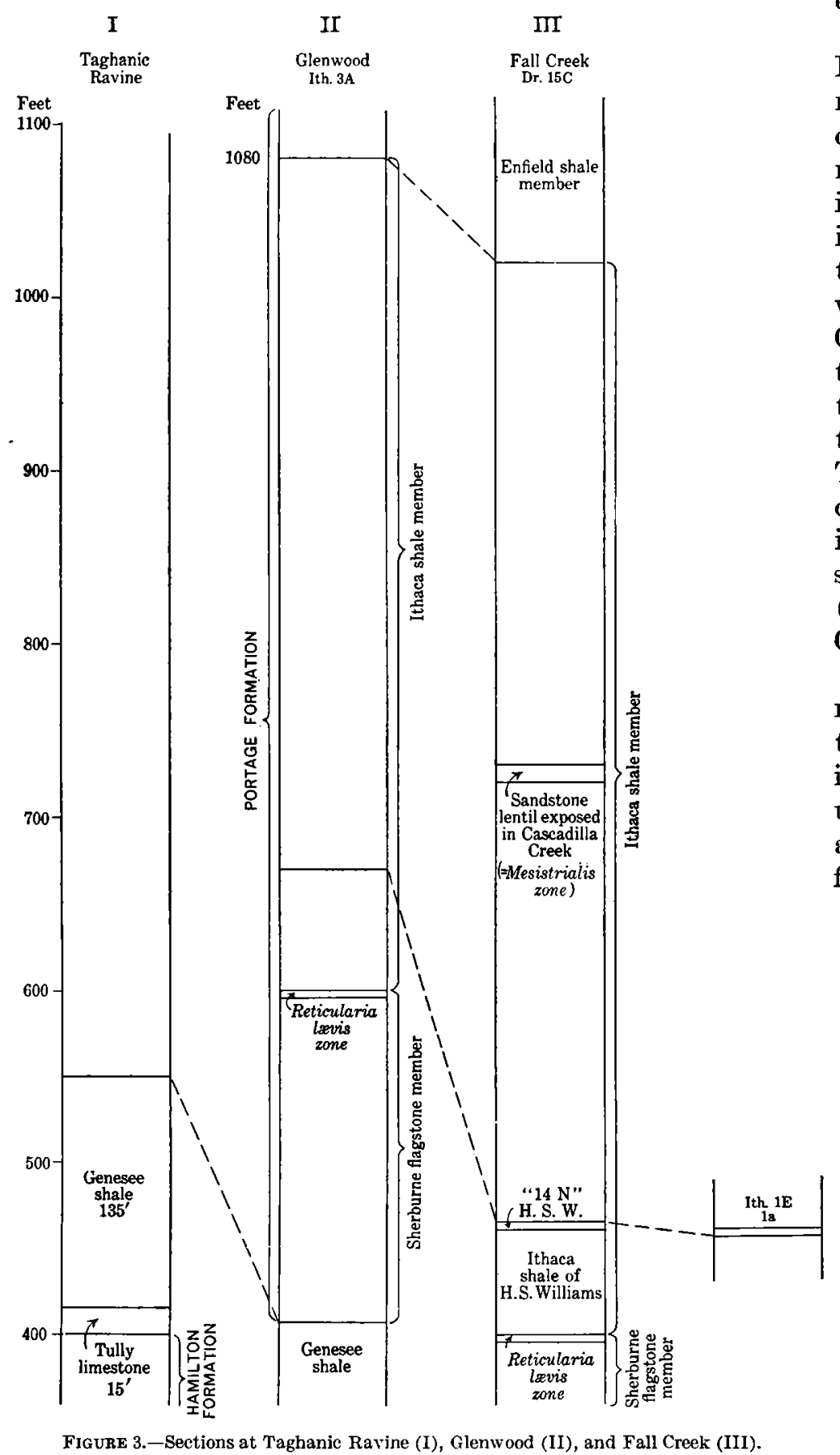
expansion.

4. The Tropidoleptus zone No. 3. At the top of the Cayuta member of the Chemung; at the close of the fullest expansion in numbers of specimens and dominance of the more characteristic Chemung species. Above this zone Spirifer disjunctus, which is characteristic of the Chemung, ceases to appear in the sections of this region, although many other characteristic Chemung species continue. This change in fauna is the chief ground for distinguishing the upper (Wellsburg sandstone) member from the lower (Cayuta shale) member of the Chemung.

The relation of the recurrent zones to the several formations and members recognized in the area may be summed up as below. These relations are also graphically shown in figure 2 .

Chemung formation:

Wellsburg sandstone member.

Cayuta shale member-

Tropidoleptus zone No. 3.

Tropidoleptus zone No. 2.

Dalmanella danbyi zone.

Portage formation:

Enfield shale memberTropidoleptus zone No. 1.

Ithaca shale member-

Mesistrialis zone.

Tropidoleptus zone of Ithaca member.

Sherburne flagstone memberReticularia lævis zone ${ }^{1}$ at top.

Genesee shale.

Tully limestone.

Hamilton formation.

\section{GEOLOGIC SECTIONS.}

Stratigraphically, the position of the recurrent zones is determined by reference to the boun'daries of the geologic formation in which the faunules indicating them occur. In few places, however, were the faunules found in so direct a relation to the stratigraphic boundaries that

IShown in Glenwood section, fig, 3. 
their precise distance above or below the terminal beds could be accurately measured. In most places the limiting beds were at a distance and it was necessary to establish their stratigraphic position by estimating the amount and direction of dip of the stratum to the nearest point where the relations to the boundaries could be observed. In a few places, however, the relation between the recurrent zones and some one of the formation boundaries was shown by nearly continuous sections.

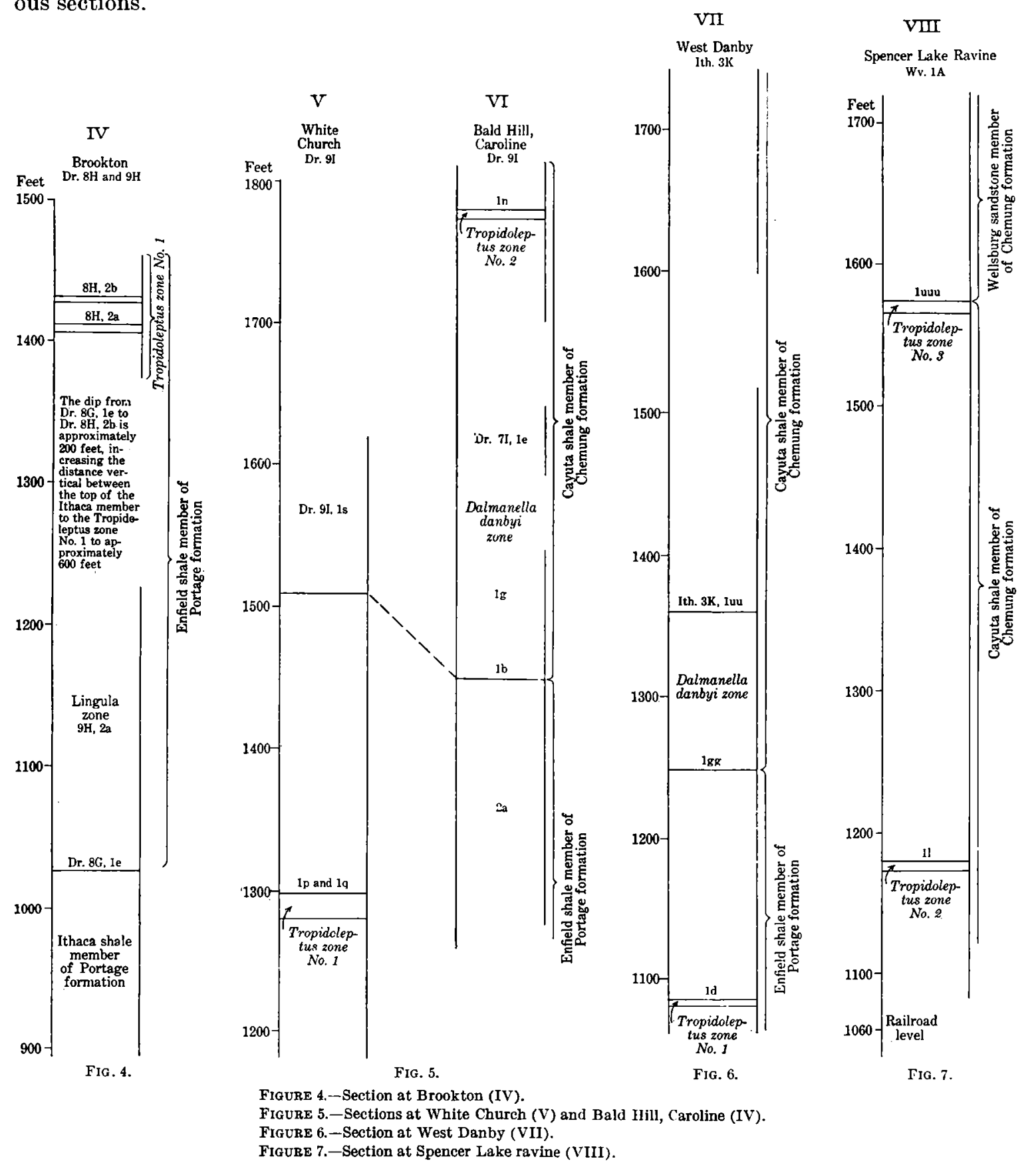

For illustrating the relations the following 27 sections (see figs. 3-14) have been selected:

I. Taghanic Ravine.

II. Glenwood, Ith. 3A.

III. Fall Creek, Dr. 15C.

IV. Brookton, Dr. $8 \mathrm{H}$ and Dr. $9 \mathrm{H}$.

V. White Church, Dr. 9I.
VI. Bald Hill (Caroline), Dr. 7I and Dr. 9I.

VII. West Danby, Ith. 3K.

VIII. Spencer Lake ravine, Wv. $1 A$.

IX. Swartwood, Wv. $7 \mathrm{~B}$ and Wv. $6 \mathrm{C}$.

X. Glory Hill, Wv. $40^{2}$. 
XXI. Messengerville and East Virgil, Ct. 8O, Hd. 5A, and Hd. $6 \mathrm{~A}$.

XXII. Marathon, Hd. 2D, Hd. 3D, Hd. 4D, Hd. 5D, and $\mathrm{Hd} .3 \mathrm{E}$.

XXIII. Killawog, Hd. 2G and $\mathrm{Bd}$. 3G.

XXIV. Harford, Hd. $13 \mathrm{E}$ and $\mathrm{Hd}$. $13 \mathrm{~F}$.

XXV. Harford Mills, Hd. 12G and Hd. 13G.

XXVI. Lisle, Hd. 1J and Hd. $2 \mathrm{~J}$.

XXVII. Berkshire, Hd. 12L.
XI. Waverly, Wv. $40^{i}$.

XII. North Candor, Ow. 9A.

XIII. Catatonk, Ow. 3G and $4 \mathrm{G}$.

XIV. Dean's tannery, Ow. $1 \mathrm{H}$.

XV. Hawley Hill, El. 7J.

XVI. Water Street bridge (Elmira), El. 2J.

XVII. Latty Brook, El. 2G.

XVIII. Breesport, El. 1E.

XIX. East Branch (Cortland), (t. $8 \mathrm{E}$ and (t. $8 \mathrm{~F}$.

XX. Blodgett Mills, Ct. 8L.

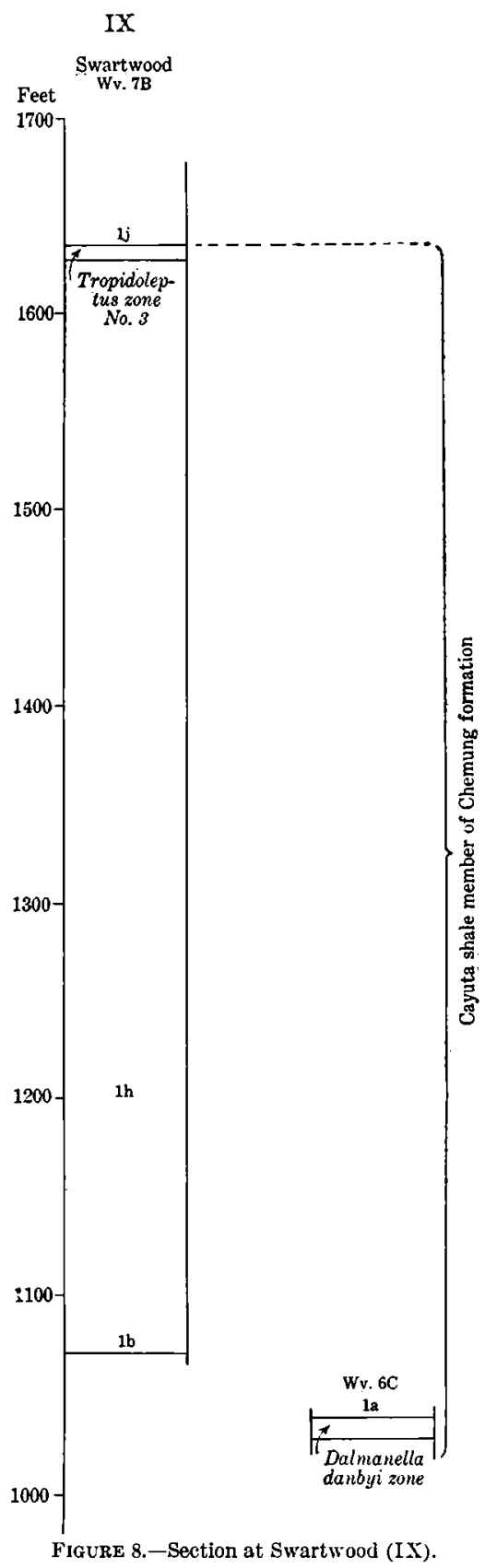
higher. tions.
Sections I, II, and III (Taghanic, Glenwood, and Fall Creek) illustrate (see fig. 3) the position of a recurrent Tropidoleptus zone (faunule Ith. 1E, 1A) which I regard as occurring lower than the zone No. 1 of this report. This zone is about 60 feetabove the Reticularia lævis zone, which is taken as the top of the Sherburne flagstone member. It lies in rocks included in the Ithaca shale member at Ithaca, but the typical fauna of the Ithaca member does not appear in force till about a hundred feet

In section III a sandstone band about halfway up contains the Spirifer mesistrialis fauna, and this band is supposed to represent the heavy-bedded sandstone at Marathon and the Oneonta sandstone of the Tioughnioga and Chenango River sec-

Section IV (fig. 4) represents the stratigraphic position of the Tropidoleptus zone No. 1 at Brookton, on the north edge of Caroline, in the Dryden quadrangle. The upper beds of the Ithaca member terminate in the exposures in Sixmile Creek at an altitude of 1,025 feet (Dr. 8G, $1 e$ ). A trace of the recurrent zone No. 1 appears on the edge of the hill south of Brookton at an altitude of 1,410 to 1,435 feet (Dr. 9H, $2 a$, and Dr. 8H, 2b). The dip, however, is strong to the south and it is estimated that it has carried the Tropidoleptus fauna nearly 200 feet lower than it would be at the Sixmile Creek exposure of the Ithaca shale member. It is estimated, 
therefore, that at this point the recurrent Tropidoleptus zone No. 1 is 600 feet above the top of the Ithaca member.

Section V (fig. 5) shows the Tropidoleptus zone No. 1 about 200 feet below the top of the Enfield member.

Section VI (fig. 5) shows the relations of the Tropidoleptus recurrent zone No. 2. It lies a little more than 300 feet above the lowest beds of the Dalmanella danbyi zone, which forms the base of the Cayuta member of the Chemung and which immediately overlies the Enfield member.

Section VII (fig. 6) shows the relations of the Tropidoleptus zone No. 1 to the base of the Chemung as seen in the West Danby section. It lies 165 feet below the base.

Section VIII (fig. 7) shows the relations of the Tropidoleptus zone No. 2 to zone No. 3 in a nearly continuous section, the two being about 400 feet apart.

Section IX (fig. 8) shows the Tropidoleptus zone No. 3 lying at the top of the Cayuta shale member in the section running southward from Swartwood in the Waverly quadrangle (Wv. 7B, $1 j$ ). The section also includes an outcrop of the Dalmanella danbyi zone (Wv. 6C, 1a) about a mile southeast of Swartwood; the particular part of this zone is not determined. All the outcrops are of the Cayuta member of the Chemung, which is shown to be at least 600 feet thick.

Sections X and XI (fig. 9) show the positions of the Tropidoleptus zones No. 2 and No. 3, at the cliff to the west of Waverly and running up Glory Hill. From the dip between the two sections it is estimated that the Tropidoleptus zone No. 3 is approximately 400 feet above the apparent level of the Tropidoleptus zone No. 2, as at Spencer Lake ravine (section VIII).

Section XII (fig. 10) shows the Tropidoleptus zone No. 1 in the midst of rocks of the Enfield member of the Portage. The top of the Enfield (and base of the Chemung) is not exposed, but by calculation based on the position of the Tropidoleptus zone No. 1 in section VI it lies a little more than 1,300 feet above sea level.

Section XIII (fig. 10) is all in the

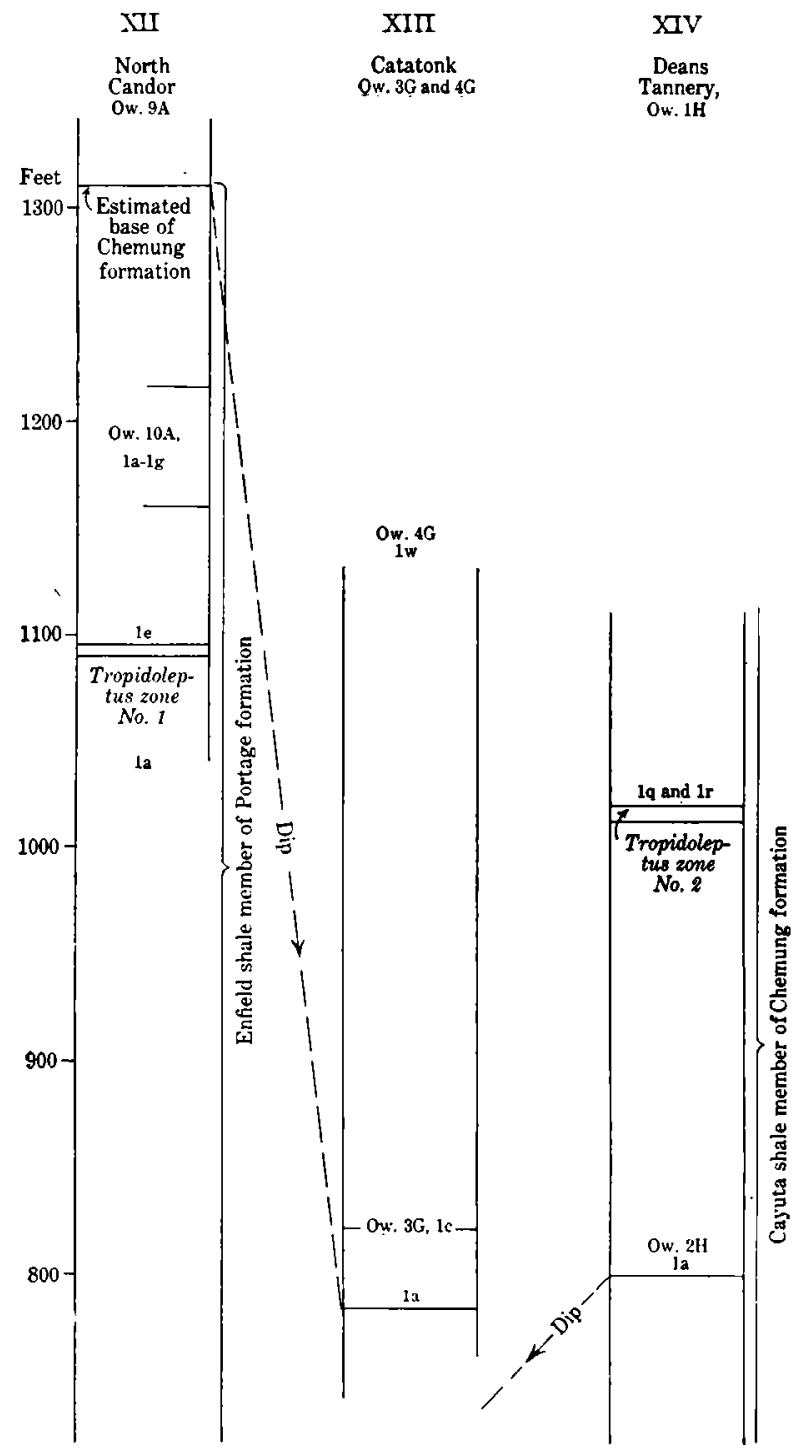

FIGURE 10.-Sections at North Candor (XII), Catatonk (XIII), and Dean's tannery (XIV).

Cayuta member; no trace of the recurrent fauna was actually seen in this section.

Section XIV (fig. 10) is also in the Cayuta member, but in it the Tropidoleptus zone No. 2 is well expressed at a little above 1,000 feet. From the measured distance of the Tropidoleptus zone No. 2 above the base of the Chemung at Bald Hill (section VI, fig. 5) it is estimated that the base of the Chemung here is as low as 700 or 750 feet above sea level.

Sections XV, XVI, XVII, XVIII (fig. 11), representing the recurrent faunules in the Elmira quadrangle, present considerable difficulty. Sections XV and XVI, in the central and eastcentral parts of the quadrangle, show the relation of the Tropidoleptus zone No. 2 (El. $7 \mathrm{~J}, 4 n$ ) 
to the Dalmanella danbyi zone and to the top of the Enfield as signified by the fossils. Throughout the Hawley Hill section (XV), ranging from 1,030 up to 1,625 feet above sea level, all the faunules are clearly Chemung, containing many specimens of Dalmanella tioga, D. carinata, and Douvillina cayuta, but so far as known showing no trace of Spirifer disjunctus. Sections XVII and XVIII show the positions of the Tropidoleptus zone No. 3. In these sections the recurrent zone (El. $2 \mathrm{G}, 1 a$, and $\mathrm{El} .1 \mathrm{E}, 1 a$ ) is near the axis of the Horseheads syncline,

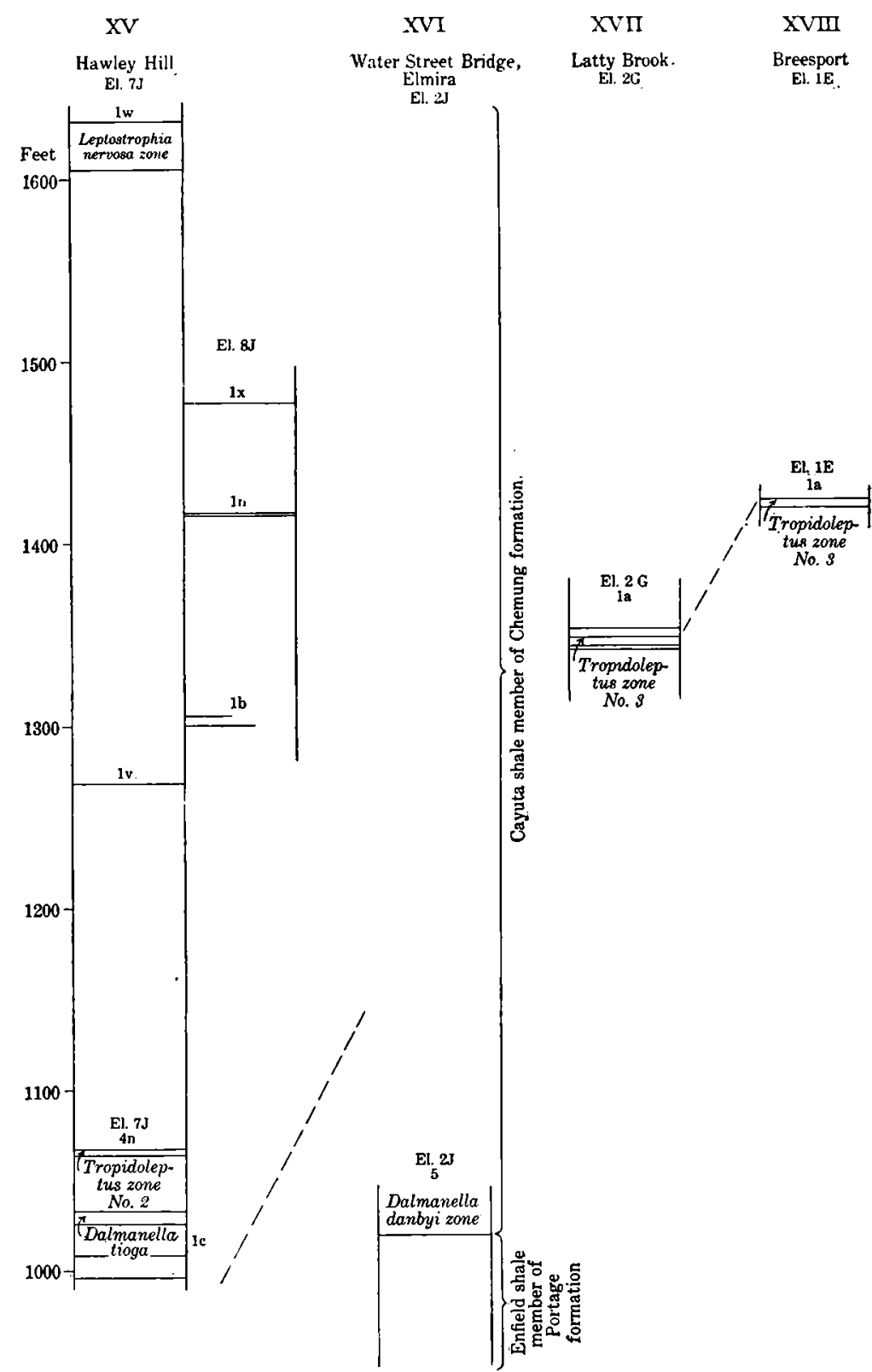

FIGURE 11.-Sections at Hawley Hill ( $\mathrm{XV}$ ); Water Street bridge, Elmira (XVI); Latty Brook (XVII); and Breesport (XVIII). whereas in the Hawley Hill section $\left(\mathrm{El} .7 \mathrm{~J}, n^{4}\right)$ it is near the axis of the Elmira anticline; the stratigraphic distance between the two zones is therefore greater than the actual difference in elevation. I have estimated that the first two represent the Tropidoleptus zone No. 3 and the latter the zone No. 2.

All the Elmira sections (XV-XVIII) indicate considerable change in the composition of the faunules, making it difficult to locate with certainty the recurrent faunules. There appears to be a continuation of the Buchiola-Manticoceras fauna up to the stage following the Dalmanella danbyi zone. Spirifer disjunctus is extremely rare, appearing in only two faunules for the whole Elmira quadrangle; one of these is near the base of the Cayuta and probably above the danbyi zone; the other (El. $2 \mathrm{I}$ ) is near the top of the $\mathrm{Ca}$ yuta. In both, the specimens are small for the species and the cardinal extremities are produced.

Examination of sections on the east side of the Elmira quadrangle (El. 2J and El. 2K) shows the succession from the Dalmanella danbyi zone to the $D$. elmira and D. tioga zones to be regular. But in the base of the section at Roricks

Glen, west of Elmira (El. $7 \mathrm{~K}$ ), the Buchiola-Manticoceras fauna laps over the Dalmanella danbyi zone. In faunules El. $7 \mathrm{~K}$ and $2 \mathrm{~L}$, Manticoceras and Buchiola are both found associated with Dalmanella tioga. It is therefore inferred that the Tropidoleptus zone No. 2 (El. $7 \mathrm{~J}, 4 n$ ) lies at least 100 feet above the Dalmanella danbyi zone in the Hawley Hill section (XV).

The faunule El. $1 \mathrm{E}, 1 a$, is at least 400 feet above El. $4 \mathrm{E}$, in which the prevailing Dalmanella is advanced beyond the $D$. danbyi stage of evolution and is therefore at approximately 
the same position in relation to the evolution of the Cayuta fauna as the Tropidoleptus zone No. 3 farther east. The faunule El. $2 \mathrm{G}$ is approximately 400 feet higher than El. 4G, which contains Dalmanella danbyi, and is therefore also the equivalent of the Tropidoleptus zone No. 3.

Sections XIX (East Branch, Cortland), XX (Blodgett Mills), and XXI (Messengerville and East Virgil, Harford quadrangle) indicate (see fig. 12) the position of the recurrent Tropidoleptus zone in the Ithaca member for its eastern extension. In these sections the general Ithaca fauna pervades a much greater thickness of strata than in the Watkins or Ithaca quadrangles. The heavy sandstone beds, which in these sections contain the earlier invasion of the Spirifer mesistrialis fauna, serve as a guide in correlating the sections. This sandstone lies at 1,800 feet in section XIX; ${ }^{1}$ at 1,400 to 1,420 in section $X X$, and at 1,200 to 1,225 in section XXI. The recurrent Tropidoleptus zone for the latter two sections (Ct. $8 \mathrm{~L}, 1 q$ and $1 r$, and $\mathrm{Hd} .5 \mathrm{~A}$, 1a) lies 120 to 150 feet below the sandstone above mentioned, which may be called the mesistrialis zone. In section XIX the Paracyclas lirata zone is approximately 400 feet below the mesistrialis zone, and so far as known the section does not contain the Tropidoleptus recurrent fauna, which stratigraphically should be approximately 250 to 275 feet above the Paracyclas zone.

In sections XXII, XXIII, XXIV (the Marathon, Killawog, and Harford sections) the Leiorhynchus globuliformis fauna pervades the strata for 300 to 400 feet above the mesistrialis zone. (See fig. 13.)

In section XXVI (Lisle) the Leiorhynchus fauna appears at 1,000 feet and the Tropidoleptus recurrent zone No. 1 at 300 feet higher. (See

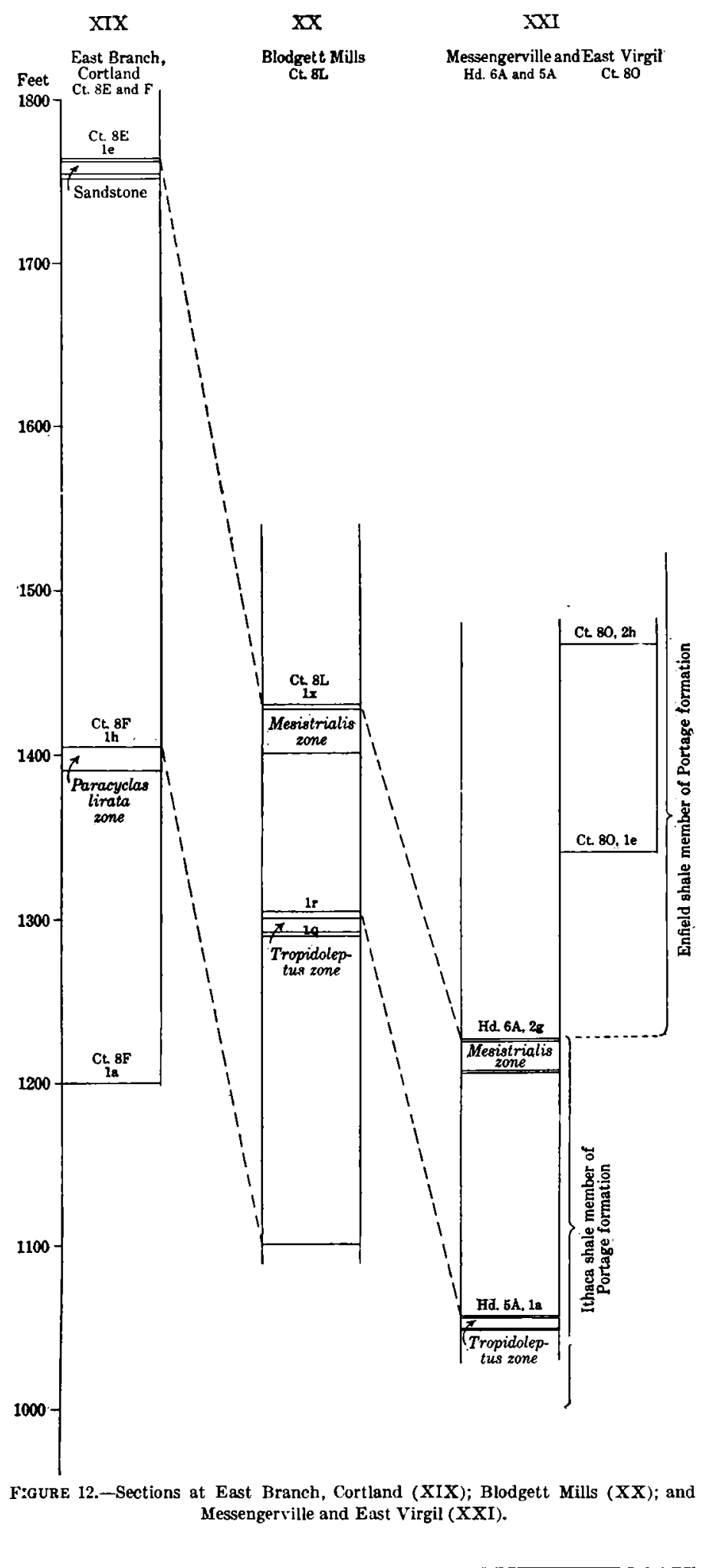
fig. 14, p. 33.)

1 In section $\mathrm{XIX}$ of fig. 12 the sandstone $\mathrm{Ct}, 8 \mathrm{E}, 1 \mathrm{e}$, is represented too low by about 30 feet. 
In section XXV (Harford Mills) it is believed that the Tropidoleptus zones (Hd. 13G, $1 k, q, r$, and $s$ ) lying between 1,400 and 1,500 feet above sea level are the equivalents of the zones $\mathrm{Hd} .2 \mathrm{~J}, 1 b$, and $1 e$ of section XXVI (Lisle) and of Hd. 12L, $1 f$, and $1 e$ of the section XXVII (Berkshire). (See fig. 14, p. 33.) These all are above the Leiorhynchus globuliformis fauna, and according to my estimates are approximately 200 feet below the base of the Chemung of that region. Thus the Tropidoleptus zone No. 1, although ranging through a greater thickness of

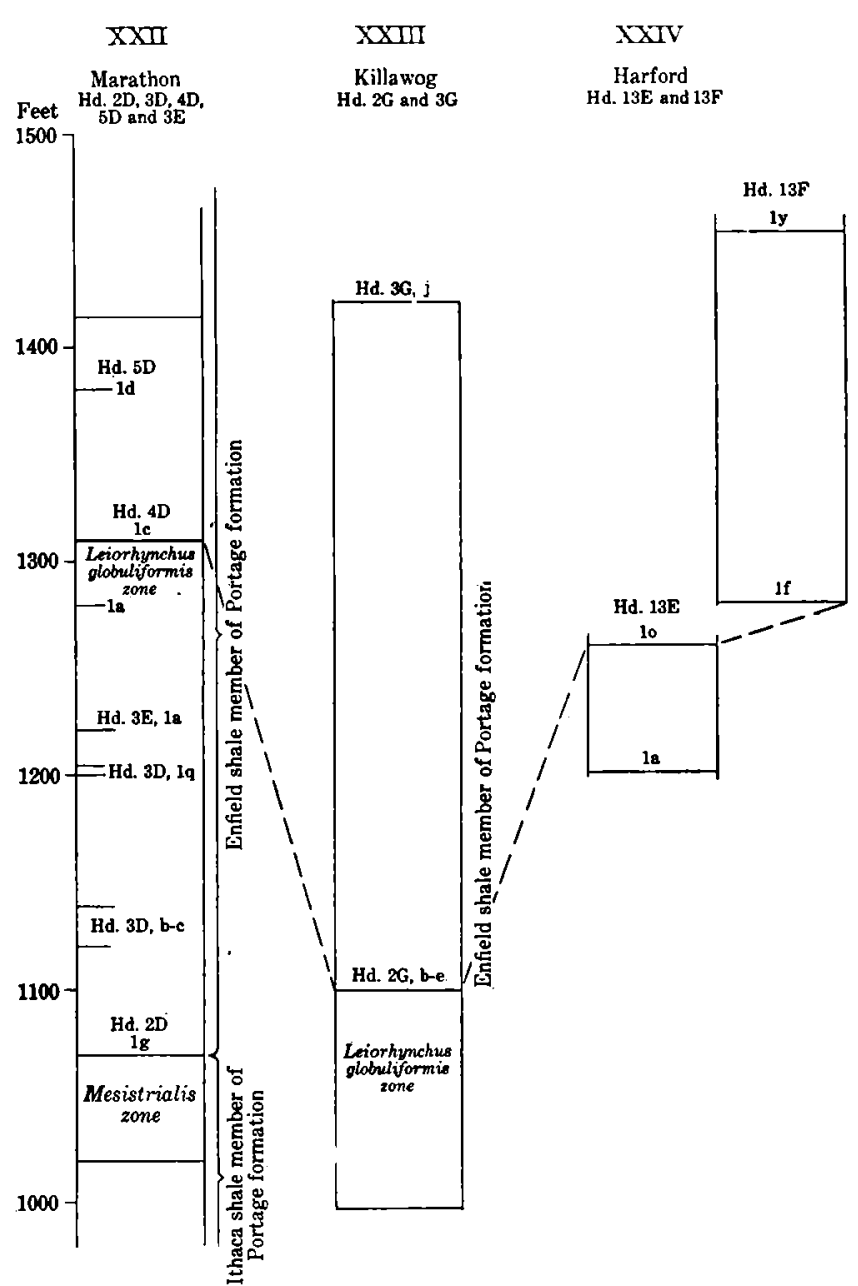

FIGURE 13.-Sections at Marathon (XXII), Killawog (XXIII), and Harford (XXIV) strata in the Harford quadrangle, appears to have reached its climax near the same stratigraphic position in the sections in relation to the Chemung base.

\section{THICKNESS OF THE FORMATIONS.}

The sections illustrate the general relationship of the recurrent Tropidoleptus zones to the stratigraphy of the several portions of the area under investigation. They also illustrate the rapid changes in the actual thickness of the sediments when classified by the fossil faunas which they contain.

The sequence of the faunas appears to be the same throughout the region examined, but the relative thickness of sediments pervaded by the same fauna differs. The general difference observed is expressed by saying that the sediments occupied by the Genesee, Portage, and Chemung faunas diminish in thickness on passing eastward across these quadrangles, and that the Ithaca fauna and the zones carrying the recurrent Tropidoleptus or Hamilton fauna each occupy less and less thicknesses of strata on passing from east to west across the same region. The direction east and west is used because the north and south relations have not been studied in sufficient detail to furnish evidence.

Oscillation of considerable extent and frequency is shown by the changes in the prevalence of the faunas over the area, a fact whose elaboration and explanation furnish extremely interesting problems for anyone who may follow up the matter. The facts already in sight suggest that over this particular area during the latter half of Devonian time the ocean currents repeatedly changed direction and that with the changes diverse faunas were made to occupy the area. 
FAUNA OF THE SEVERAL ZONES.

GROUPING BY FAUNULES.

By gathering the faunules into groups by zones certain general characteristics of the composition of the fauna peculiar to each particular stage of incursion into the region are recognized. Such a grouping of the faunule samples is made in the following table:

Assignment of the faunules to the several zones.

Tropidoleptus zone of the Ithaca shale member.

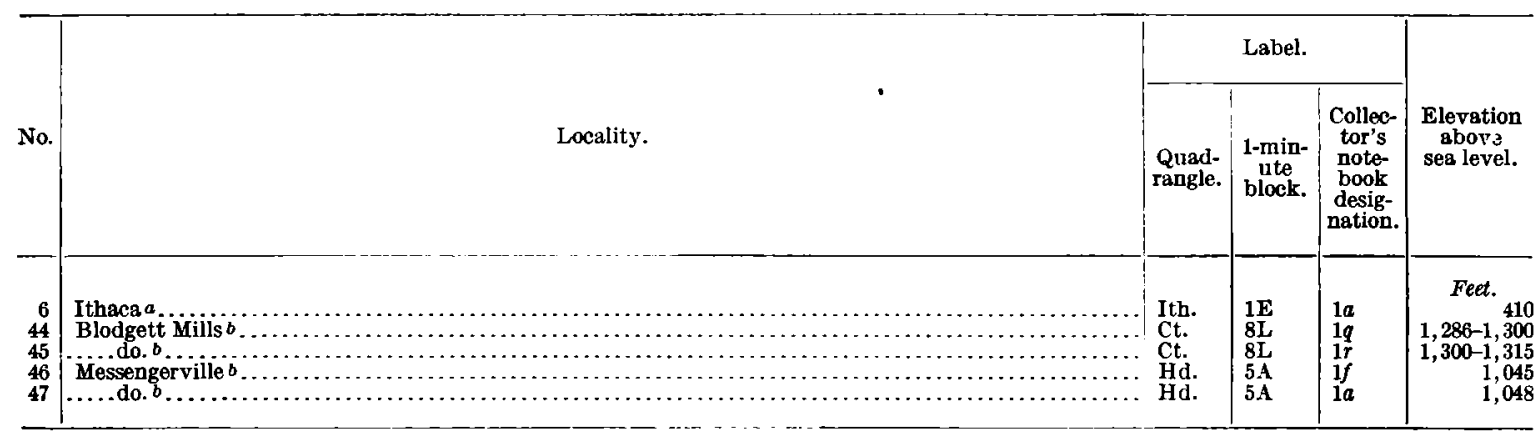

Tropldoleptus zone No. 1 (Enfleld shale member).

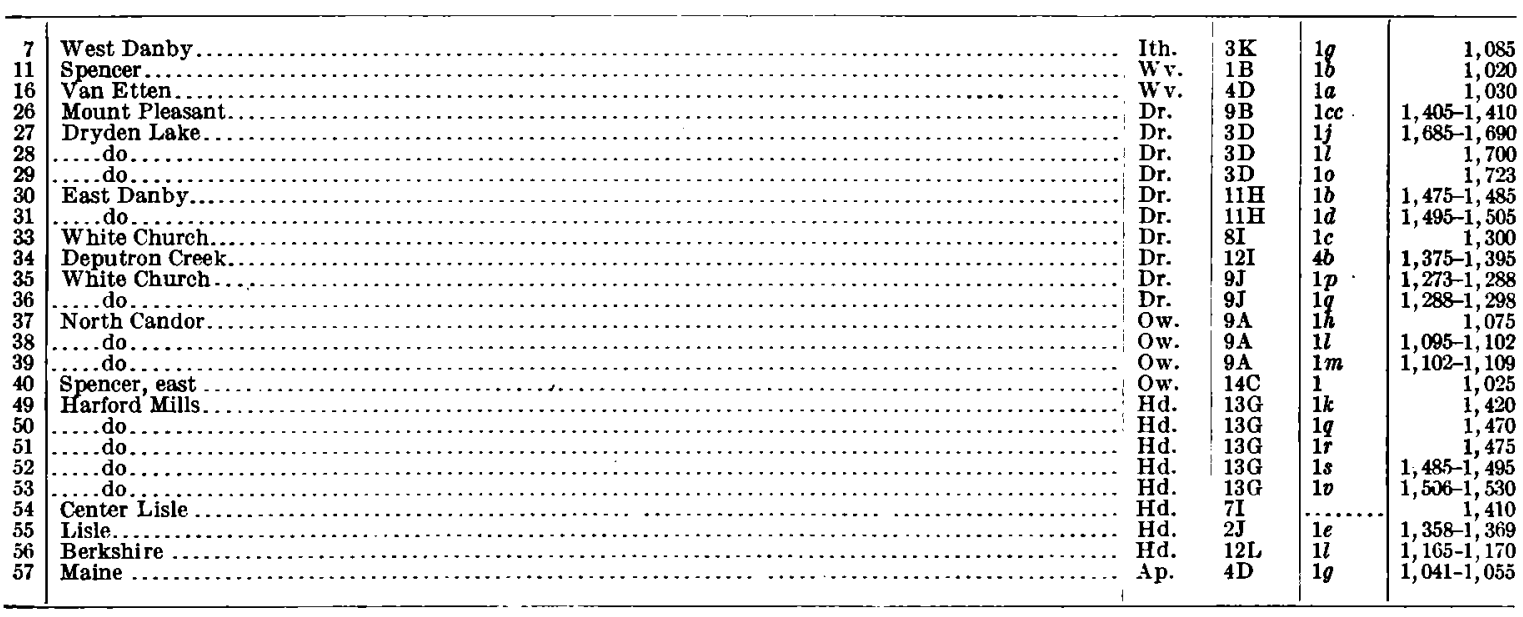

Tropidoleptus zone No. 2 (Caycta shale member).

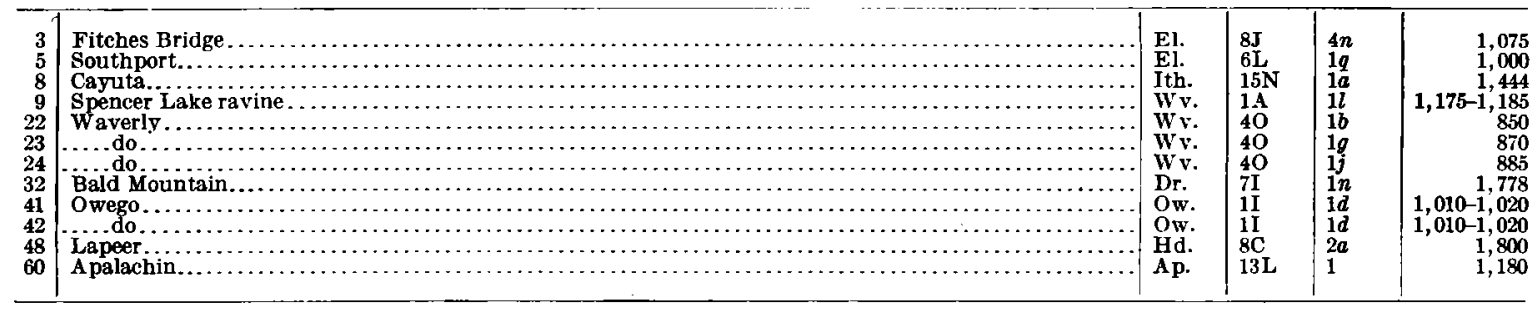

$a$ In the rocks in the neighborhood of Ithaca other traces of the Tropidoleptus fauna have been found. They all appear to have come from near the horizon where we have drawn the boundary between the Sherburne and Ithaca members: but their exact location is not recorded. They may be designated as follows: B, base of Buttermilk Creek ravine, Cornell Museum No. 10457; C, Cascadilla Creek near base; D, Burdicks Glen,

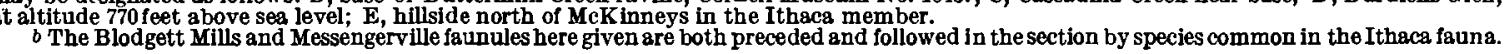


Assignment of the faunules to the several zones-Continued.

Tropidoleptus zone No. 3 (Caýta shale member).

\begin{tabular}{|c|c|c|c|c|c|}
\hline \multirow[b]{2}{*}{ No. } & \multirow[b]{2}{*}{ Locality. } & \multicolumn{3}{|c|}{ Label. } & \multirow[b]{2}{*}{$\begin{array}{l}\text { Elevation } \\
\text { above } \\
\text { sea level. }\end{array}$} \\
\hline & & $\begin{array}{l}\text { Quad- } \\
\text { rangle. }\end{array}$ & $\begin{array}{l}\text { 1-min- } \\
\text { ute } \\
\text { block. }\end{array}$ & $\begin{array}{c}\text { Collec- } \\
\text { tor's } \\
\text { note- } \\
\text { book } \\
\text { desig- } \\
\text { nation. }\end{array}$ & \\
\hline $\begin{array}{r}1 \\
2 \\
4 \\
10 \\
12 \\
13 \\
14 \\
15 \\
17 \\
18 \\
19 \\
20 \\
21 \\
25 \\
43 \\
58 \\
59 \\
61 \\
62 \\
63\end{array}$ & 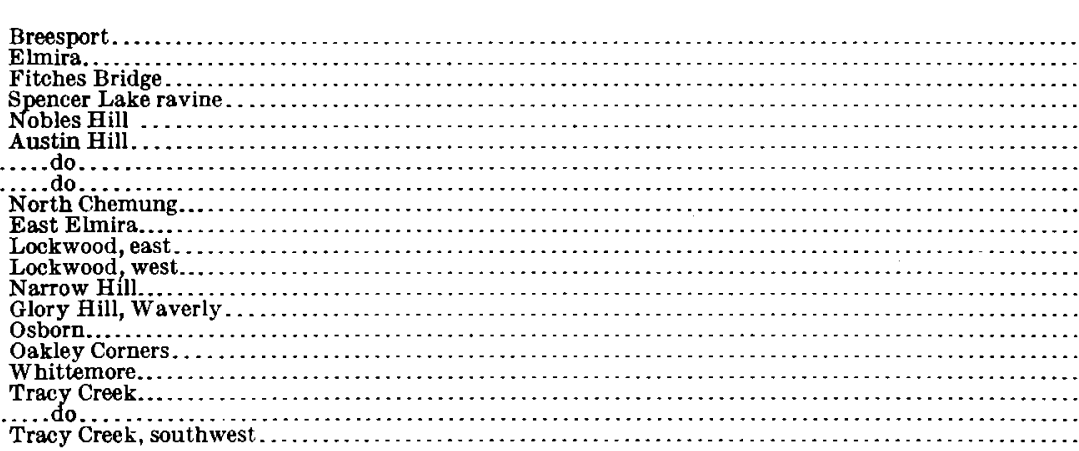 & $\begin{array}{l}\text { El. } \\
\text { El. } \\
\text { El. } \\
\text { Wv. } \\
\text { Wv. } \\
\text { Wv. } \\
\text { Wv. } \\
\text { Wv. } \\
\text { Wv. } \\
\text { Wv. } \\
\text { Wv. } \\
\text { Wv. } \\
\text { Wv. } \\
\text { Wv. } \\
\text { Ow. } \\
\text { Ap. } \\
\text { Ap. } \\
\text { Ap. } \\
\text { Ap. } \\
\text { Ap. }\end{array}$ & $\begin{array}{l}1 \mathrm{E} \\
2 \mathrm{G} \\
8 \mathrm{~J} \\
1 \mathrm{~A} \\
6 \mathrm{~B} \\
7 \mathrm{~B} . \\
7 \mathrm{~B} \\
7 \mathrm{~B} \\
11 \mathrm{H} \\
14 \mathrm{I} \\
3 \mathrm{~J} \\
3 \mathrm{~J} \\
9 \mathrm{~N} \\
4 \mathrm{O} \\
12 \mathrm{O} \\
11 \mathrm{E} \\
8 \mathrm{G} \\
5 \mathrm{~N} \\
6 \mathrm{~N} \\
6 \mathrm{O}\end{array}$ & $\begin{array}{l}1 a \\
1 a \\
1 n \\
1 v v v \\
1 a \\
1 j \\
1 j^{2} \\
1 j^{3} \\
1 a \\
1 d \\
1 d \\
2 a \\
1 a a \\
2 n n \\
1 p \\
1 a \\
3 a \\
1 c \\
1 a \\
4\end{array}$ & $\begin{array}{r}\text { Feet. } \\
1,420 \\
1,345 \\
1,415-1,420 \\
1,565-1,570 \\
1,561 \\
1,610 \\
1,610 \\
1,610 \\
1,440 \\
1,500 \\
1,345 \\
1,339 \\
889 \\
1,165-1,170 \\
1,112 \\
1,500 \\
1,490 \\
1,300 \\
1,402 \\
1,600\end{array}$ \\
\hline
\end{tabular}

GROUPING BY SPECIES AND GENERA.

In the accompanying table the several species and genera identified in the sample faunules are tabulated together, in order to show the frequency of appearance of each in the whole series and in separate zones.

The table shows about 20 genera of brachiopods, about 30 genera of pelecypods, and about 20 other genera, chiefly gastropods. A few species are represented in a large number of the samples; but the great majority of the species, and even genera, are represented in so few faunules and are so irregularly distributed by zones as to suggest that they are of slight significance. Of the 87 names tabulated only 23 appear in as many as 10 of the 63 faunules, and only 11 names appear in 20 or more of them.

Two explanations may be assigned for this rarity of specimens common to the faunules: The great majority of the species listed may (1) be merely representatives of the general Devonian fauna which have accidentally gotten into these particular samples; or (2) they may really be very rare in that fauna and therefore only accidentally found in any sample. In the latter case they may be of greater significance than is at present apparent; but in neither case is their significance evident.

In several genera I have gathered closely related species, the differentiation of which is significant for the purposes of this paper. For instance in bringing four species of Productella into the order of sequence as listed, general indication of the actual succession is expressed. So the camarotœchias pass evidently from the $C$. congregata type through the $C$. eximia-stephani into the C. sappho-contracta group. In citing Chonetes, the specific names setigera-scitulus are united by hyphen; this is to indicate that there is no evident and sharp distinction between the forms which have been often cited as distinct species under these separate names.

In some genera (Productella, Camarotœchia, Leiorhynchus, Leptodesma, Modiomorpha, Loxonema, and perhaps some others) the considerable amount of fluctuation in characters observed calls for deeper investigation in order to determine to what extent the differences are purely fluctuating variations and to what extent they are of specific value. In the table I have indicated by a check every definite indication of the presence in the faunules of each genus (or species). In regard to a few of these the evidence is slight, and future and larger collections may compel revision of the list. Undoubtedly fuller collections will show a more general presence of some of the species named than I am able to record at the present time. 


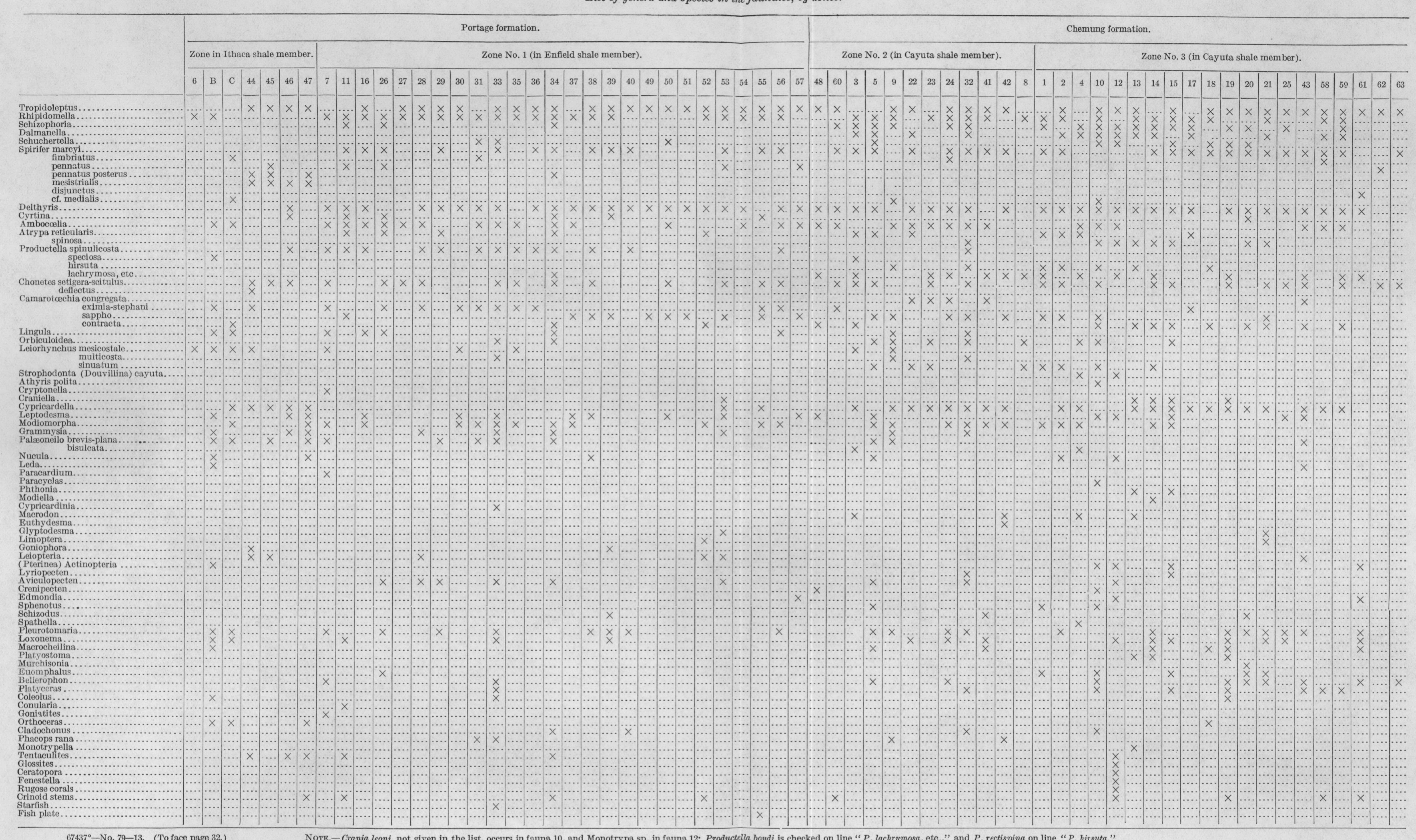



In preparing the list $I$ have used only the generic names in a large rumber of cases in order to bring out the degree of similarity in composition of the several samples. The considerable amount of fluctuation expressed by the characters used by authors in defining species would necessitate the frequent use of a question mark in place of a positive check if the name of the species were to be cited. This uncertainty as to the specific identity of the specimens, however, may not indicate uncertainty as to the presence of forms of a common race or common origin, and it is identity of race which is the significant fact indicated in this table. In regard to genera, which appear but infrequently among the samples, the facts are correct so far as they arestated; but they are deficient in furnishing testimony regarding the common composition of the samples so far as such genera are concerned, and of course also as to the particular species of the genera. But in regard to genera which reappear in a majority of samples and outside these particular zones do not appear in the faunules of the same section, the evidence is clear that the genus is an intrinsic part of the faunal group the recurrence of which I am considering. Whether the species of the genus have fluctuated or evolved differences with each return of the fauna is a question which can not be properly examined until the common source of the specimens compared is thoroughly established.

Only such genera, therefore, as appear in such a large number of the samples from each zone (and also in each of the successive zones) as to leave no doubt of their intrinsic place in the constitution of the fauna can be used as giving positive indication of common origin and continuity of genetic relationship during the successive shiftings of the faunas from zone to zone. Other

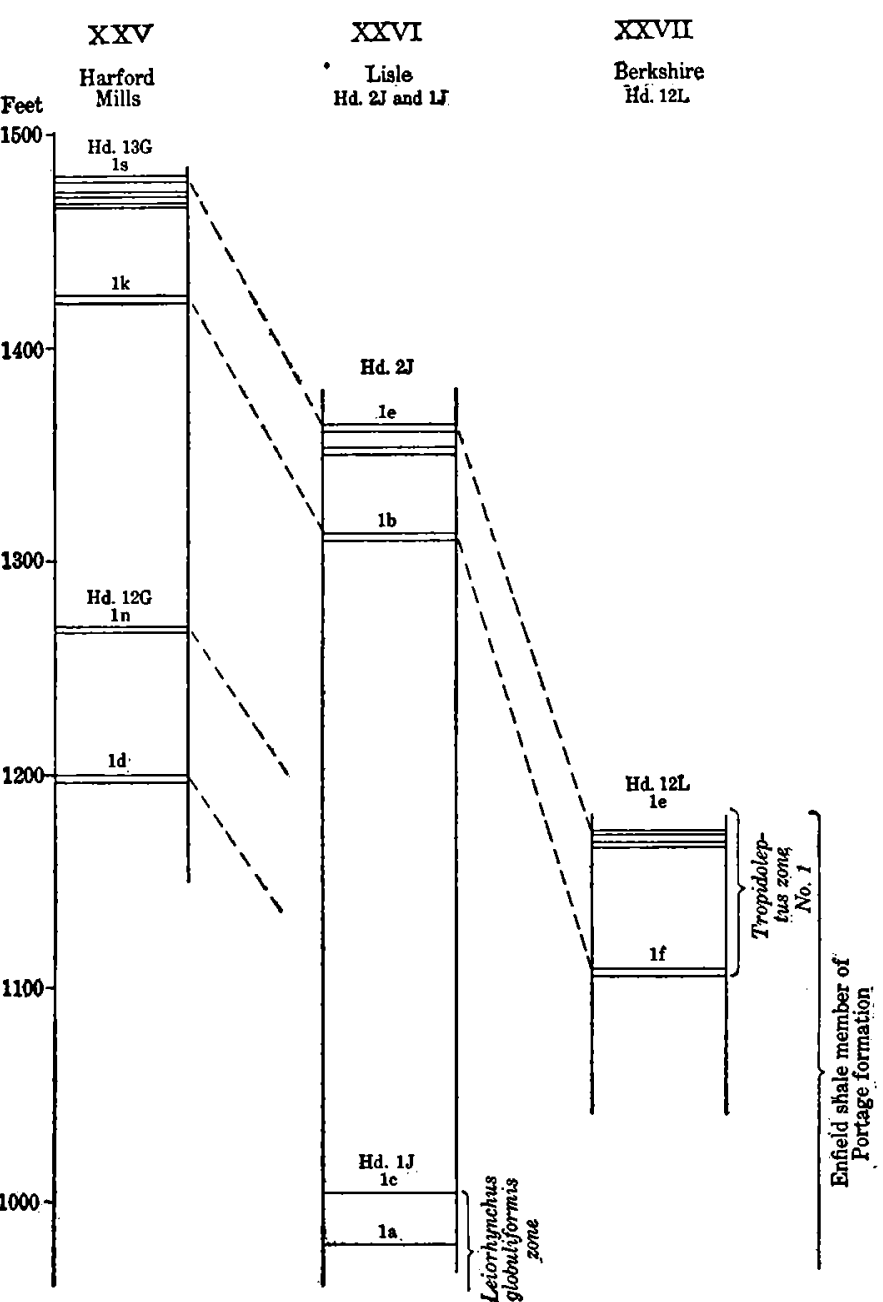

FIGURE 14.-Sections at Harford Mills (XXV), Lisle (XXVI), and Berkshire (XXVII). genera may be added by more thorough explorations of the beds containing the fossils, but they must be left out of the investigation until their place in the faunules is thoroughly established.

The imperfection of evidence in the case of the Tropidoleptus zone of the Ithaca member is such that, although first in order of time, its consideration will be omitted until after the other three zones have been examined. (See pp. 71-72.) 
Tropidoleptus zone No. 1 is expressed in twenty-six faunules (see table, p. 29). At least eight genera are represented in twelve of these, and no other genus appears in more than nine of them.

Number of faunules containing the more abundant genera and species of Tropidoleptus zone No. 1.

Tropidoleptus.......................... 21 | Chonetes.............................. 12

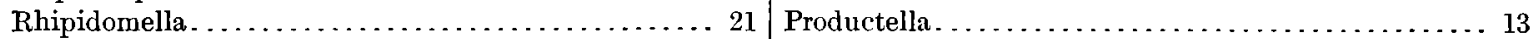

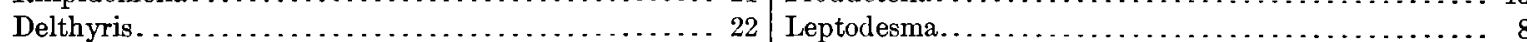

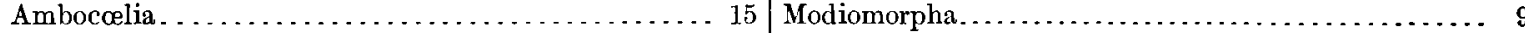

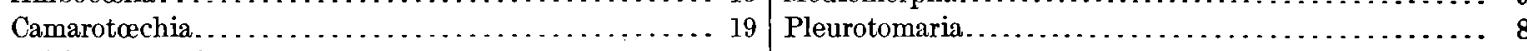

Spirifer marcyi............................. 13

The first eight genera may be considered fairly dominant in the zone; at least they show the highest degree of frequency of appearance in the collections from this zone now in hand. Sixteen of the twenty-six samples contain five or more of this group of eight dominant genera; in detail, three faunules contain eight of the dominant eight genera; two contain seven; seven contain six; four contain five; seven contain four; and three contain three.

All these genera were represented by the same or closely related species at an earlier stage in the Hamilton formation in the region immediately north of the area from which these samples came. It is, therefore, reasonable to assume that these eight genera occurring in the fauna of the zone No. 1 were descended directly from Hamilton species or from species having a common source with Hamilton species.

The zone No. 1 is surrounded both below and above by rock containing the species peculiar to the Buchiola-Manticoceras fauna of the Portage, from which it is not reasonable to suppose that these eight species could have directly descended.

TROPIDOLEPTUS ZONE NO. 2 (CAYUTA SHALE MEMBER).

The zone No. 2 is represented in twelve faunules. Eleven genera and species are found in six or more of these.

\section{Number of faunules containing the more abundant genera of Tropidoleptus zone No. 2.}

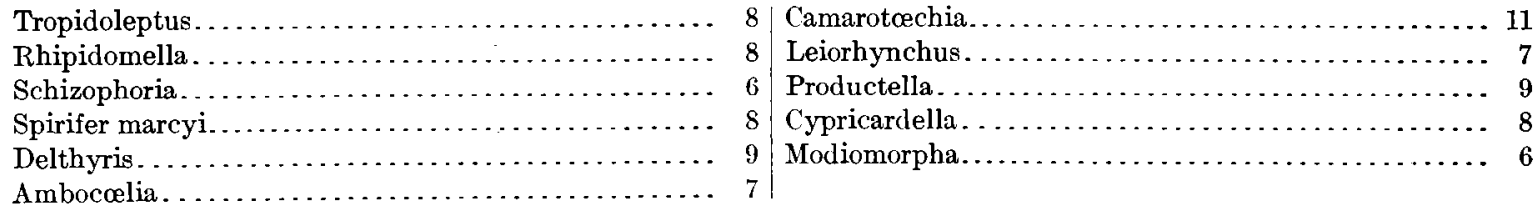

Only two of the twelve faunules have less than seven of the above eleven genera in their faunal composition. One faunule, No. 32, has all eleven, and four have as many as eight of them.

\section{TROPIDOLEPTUS ZONE NO. 3 (CAYUTA SHALE MEMBER).}

The Tropidoleptus zone No. 3 is represented in twenty faunules. Eleven genera are found in eleven or more of these, and eight appear in twelve of the twenty, constituting the dominant character of the fauna.

Number of faunules containing the more abundant genera of Tropidoleptus zone No. 3.

\begin{tabular}{|c|c|c|}
\hline Tropidoleptus. & 16 & Delthyris.. \\
\hline Rhipidomella. & 11 & Productella $\ldots \ldots \ldots \ldots \ldots \ldots \ldots \ldots \ldots \ldots \ldots$ \\
\hline Schizophoria.. & 12 & Atrypa \\
\hline Dalmanella.. & 10 & Camarotœchia $\ldots \ldots \ldots \ldots \ldots \ldots \ldots \ldots \ldots \ldots \ldots \ldots \ldots \ldots \ldots$ \\
\hline Spirifer marcyi. & 14 & 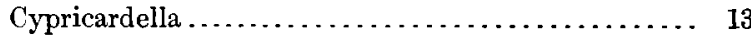 \\
\hline Chonetes....... & 12 & \\
\hline
\end{tabular}


SUMOMARY.

The occurrence of the Tropidoleptus fauna and its associates is summed up as follows:

Number of faunules containing the more abundant genera in the three recurrent zones.

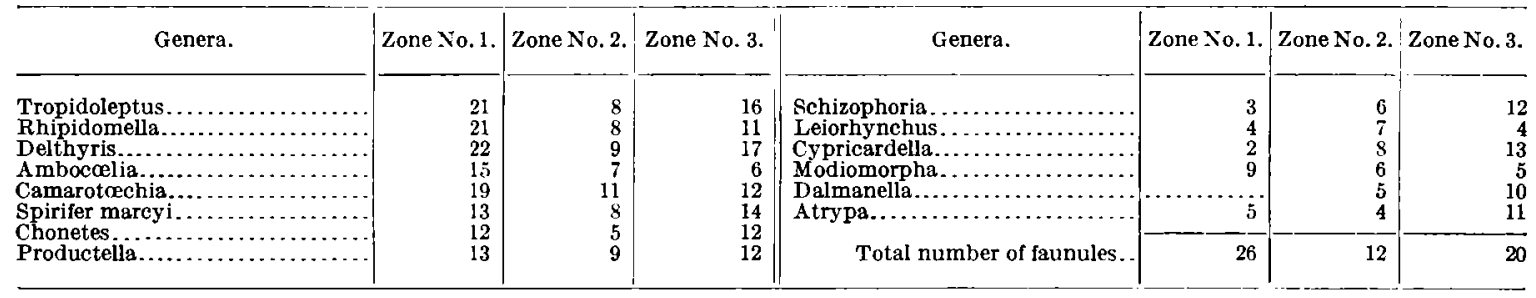

Only fourteen genera occur in 50 per cent of the faunules of some one zone. I have included Chonetes in the lot of zone No. 1, although so far it has been found in only twelve of the twentysix faunules and, strictly, one more occurrence is necessary to bring it up to the 50 per cent. Spirifer marcyi is treated as a generic group and separated from the other spirifers because its specific characteristics are so closely differentiated in the Hamilton that it may safely be treated as genetically distinct from the other racial lines of Spirifer appearing after the Hamilton epoch. All the other species may be passed over until some other evidence can be adduced to show that they properly belong to these particular faunules.

Examination of the several genera named gives grounds for refusing to consider some of them as recurrent expressions of a common magna fauna associated with Hamilton.

Ambocclia shows a decided falling off on passing upward into zone No. 3, where it shows itself in only six of the twenty samples. This genus was present in all but four of the twenty-five separate faunules of the Marcellus and Hamilton recorded by Cleland. ${ }^{1}$ It seems reasonable to suppose, therefore, that its origin is from the same source and that its absence from many of the late Chemung faunules is coincident with its general decadence; since, as a genus, it is not reported after the Chemung. It may be retained, therefore, as probably having its source from the Hamilton magna fauna, ${ }^{2}$ although it is not restricted to these recurrent zones in the Upper Devonian.

Chonetes is so frequently met with in other faunas of the Upper Devonian that $I$ think it must be omitted from the list as of doubtful origin.

The fact that the Productella types of the zone No. 1 are more closely related to $P$. spinulicosta, which is common in the Hamilton below, than to the species common in the general Chemung fauna, leads me to think that its appearance in the zone No. 1 is due to direct descent from Hamilton representatives of the genus. The new types of the genus, which are abundant throughout the Chemung, may have taken their origin from the Spirifer disjunctus fauna of the Iowa and western region, or they may be accounted for by the mingling of the two lines of descent; for the present they may be held in the list.

Schizophoria is very rare in the zone No. 1, and is not recorded by Cleland as being present in the underlying Hamilton. It is also an abundant species in the general Chemung fauna and in the Upper Devonian is associated with Spirifer disjunctus. I conclude, therefore, that its appearance in the recurrent faunules is to be accounted for otherwise than by descent from the Hamilton magna fauna. It should therefore be omitted from the list.

Dalmanella for the same reason may be excluded, and Atrypa, although it may have come from Hamiltonian ancestors, may as likely have been derived from the Spirifer disjunctus fauna. It is not peculiar to the three zones.

Leiorhynchus, Cypricardella, and Modiomorpha are at least doubtful, as they are so rare in the zone No. 1. They should be excluded in absence of good reasons to the contrary.

After this first critical exclusion of genera from the list on account of their unsatisfactory demonstration of Hamiltonian ancestry, there remain only Tropidoleptus, Rhipidomella, Del-

1 Cleland, H. F., A study of the Hamilton fauna of the Cayuga Lake section: Bull. L. S. Geol. Survey No. 206, 1905 , p. 97.

2 On the fossil faunas of the St. Helms breccia: Trans. Roy. Soc. Canada, 3d ser., vol. 3, 1910, p. 241. 
thyris, Camarotcechia, Spirifer marcyi, and Productella. With the evidence at hand the presumption is that the above six genera constitute an essential element of each of the faunules occurring in the Tropidoleptus zones Nos. 1, 2, and 3, and that they are genetically allied to the underlying general Hamilton magna fauna.

Examination of the list shows that the genera fall into two classes. Tropidoleptus, Rhipidomella, and Spirifer marcyi, so far as my search has extended, are found above the Hamilton only in the recurrent Tropidoleptus zones Nos. 1,2, and 3. Delthyris, Camarotœchia, and Productella, on the other hand, although very commonly present in the recurrent zones, appear also in other parts of the sections where the first three genera are lacking.

The range and distribution of these last three genera are significant and interesting and call for further investigation. In general the facts indicate that the latter three genera entered the area with the rest of the recurrent fauna, but that instead of departing with it, when the conditions coincident with entrance were withdrawn, they remained on the ground and suffered evolutional modification. The first three genera, on the other hand, persistently retained their typical characters, suffering a very slight modification of form, and thus mark the narrow limits of the conditions appropriate to their existence.

The genera, except Productella and including Cypricardella, will be critically examined to make sure of their relationship to the antecedent Hamilton fauna and of their title to be regarded as recurrent representatives of that fauna. Productella is omitted, because, though a dominant representative of the recurrent faunules, it is not separable from its representatives outside the zones of recurrence. The genus Cypricardella, however, is included because in two of the zones the species C. bellistriata, a Hamilton species, is diagnostic of the Tropidoleptus fauna.

\section{GENUS TROPIDOLEPTUS.}

CONTINUITY OF THE GENUS.

The fact that Tropidoleptus differs so widely from any other genus of brachiopods is, on the face of it, strong evidence of the racial continuity of the Hamilton representatives into the later Upper Devonian beds of the New York area. Further, although it is probable that the identity in the generic characters of the Hamilton and the Upper Devonian species is sufficient to establish the recurrence of the genus, I have thought it well to set down here all available evidence bearing on the continuity of the race, designing thus to furnish a solid foundation for future study of the paths of migration of the fauna with which it is associated. Accordingly I have examined critically not only the generic but the specific and fluctuating characters expressed in the recurrent zones, comparing them with the typical characters expressed by the Hamilton representative of Tropidoleptus carinatus. I have not considered it necessary to bring into the present paper a comparison of these representatives of the genus with representatives from distant regions, interesting though this would be, as to do so properly would require the examination of specimens which are not at hand for study.

\section{SPECIFIC CHARACTERS.}

In the literature all the Hamilton representatives of the genus Tropidoleptus Hall have been assigned to the one species $T$. carinatus. By this assignment specimens differing in several respects are included under one specific name, the differences being held to be unimportant or of so fluctuating a character as not to entitle them to specific or even varietal discrimination. For taxonomic classification the constant characters may be regarded as of generic or of higher rank; they include, of course, those indicative of specific rank.

The species Tropidoleptus carinatus (Conrad) was originally defined by Conrad $^{1}$ in 1839 under the name Strophomena carinata as follows (no figure was given):

Shell suborbicular, with from 16 to 18 angular radiating ribs; superior valve with a sinus in the middle; inferior valve angulated in the middle, slightly flattened on the side; base prominent and subangulated in the middle; basal margin sinuous. Length, $\frac{3}{3}$ inch.

Localities: Helderberg Mountain, in limestone; Ludlowville. 
In 1857 James Hall ${ }^{1}$ defined the genus 'Tropidoleptus, taking Conrad's species as the type and publishing two illustrations of Tropidoleptus carinatus. He gave the geologic position and locality for the species as follows:

In the Hamilton group in Schoharie County, and at Eighteenmile Creek on Lake Erie; upon the shores of Seneca, Cayuga, and Canandaigua lakes, extending, in fact, throughout the entire breadth of the State from near the $H$ !tdson River on the east to Lake Erie on the west. It likewise occurs in rocks of the same age in Illinois and Iowa.

\section{FLUCTUATING CHARACTERS.}

If it be assumed that the figure published by Hall in 1857 is the type figure of the species, and that the figures given ${ }^{2}$ in the full illustration of the species in 1867 represent a single species, it is evident that in several respects the characters are fluctuating. In Hall's Plate LXII ${ }^{2}$ figures $3 \mathrm{j}$ and $3 \mathrm{k}$ are of the same form as the two figures published ${ }^{3}$ in 18.57 and may furnish a basis for discriminating a typical variety of the species, Tropidoleptus carinatus typicalis, in which the cardinal angles are rounded; the angle formed by the lines of growth of the sides with the cardinal angle is $90^{\circ}$ but not greater; one strong central plication is on the convex valve; a slight sulcus appears in the center of the concave valve; 10 plications are visible at each side of the median rib on the convex valve; and the bifurcation of plications is not evident.

A second variety may be recognized ${ }^{2}$ in figures $3 t, 3 w, 3 u$, and $3 x$. In these the cardinal angles are slightly produced beyond the lateral margin, and the angle formed by the sides with the cardinal lines less than a right angle. This variety may be called Tropidoleptus carinatus alpha.

A third variety is represented ${ }^{2}$ by figures $3 p$ and $3 r$. In this form the length of the cardinal border is decidedly less than the greatest diameter at about the middle of the shell, and the angle formed is greater than a right angle. The form may be called Tropidoleptus carinatus beta.

A fourth variety is expressed ${ }^{2}$ by figures $2 a, 2 b$, and $2 c$, in which the sides are approximately at right angles with the cardinal border, but the width of the shell is less than or equal to the length, producing an elongate shell. To this form may be given the name Tropidoleptus carinatus gamma.

A fifth variety is expressed ${ }^{2}$ by figures $3 \mathrm{~d}$ and $3 \mathrm{e}$, in which the number of plications exceeds the typical number; the median rib is not conspicuously larger than the adjacent plications; the cardinal angle is slightly mucronate and is less than a right angle. This form may be called Tropidoleptus carinatus delta.

A sixth variety is represented ${ }^{2}$ by figure 31 , a large valve in which the plications near the front margin abruptly bifurcate. Its general form is that of the variety of typicalis. It may be called Tropidoleptus carinatus epsilon.

Examination of many sets of the species from the Hamilton leads to the conclusion that these several varieties are not differentiated sharply from one another but are expressions of varying stages of fluctuation of more or less normally plastic characters. Nevertheless, as fluctuating characters they serve the purpose of distinguishing different expressions of the species, and hence of the tendency toward modification observed in the subsequent history of the race in the New York Basin.

The question whether the fluctuating characters are of specific or varietal rank is largely a matter of opinion, to be answered variously by students according to their personal prejudices. It is, however, important to examine critically the fluctuating characters in order to ascertain what, if any, effect has been produced by the passage of time, and what may be the normal amplitude of fluctuation at each stage in the history of the race.

1 Tenth Ann. Rept. New York State Museum, 1857, pp. 151-152.

2 Paleontology: Geol. Survey New York, vol. 4, 1867, Pl. LXII.

3 Tenth Ann. Rept. New York State Museum, 1857, p. 152. 
STATUS OF FLUCTUATING CHARACTERS IN ZONE No. 1.

Specimens examined.-In order to determine the status of the fluctuating characters in Tropidoleptus zone No. 1, I have taken one of the faunules (No. 50, Harford Mills section, Hd. 13G, $1 r$ ) from which a considerable number of specimens have been obtained in good state of preservation. The locality is in the Harford quadrangle, on the eastern side of the Watkins Glen-Catatonk district.

From this faunule I have selected and mounted on tablets for study 88 specimens of Tropidoleptus. (See Pls. I, II.) They are all represented by sandstone molds, from which the calcareous shell itself has been leached off in weathering. They present, therefore, a different appearance from the figures illustrating the original description of the Hamilton species; ${ }^{1}$ but they exhibit, nevertheless, in very good state, the surface characters of both the interior and exterior of both valves and furnish good basis for comparison of the characters represented. Specimens 1 to 27 (Pl. I, figs. 1-27) exhibit interior molds of pedicle valves; 28 to 38 (Pl. I, figs. 28-38), exhibit interior molds of brachial valves; 39 and 42 to 88 (Pl. I, figs. 39 and 42-64, and Pl. II, figs. 1-24) show exterior molds of brachial valves; 40 and 41 (Pl. I, figs. 40 and 41 ) show exteriors molds of pedicle valves.

The primary reason for illustrating the fauna by molds instead of by the actual shells is found in the nature of the sediments in which the latter were buried. The specimens upon which the specific original descriptions were based were fossilized in a soft mud shale. The soft shale weathers much more readily than the sheli substance, and the shells are easily removable from the sediments.

The specimens in the Harford Mills section, on the other hand, were embedded in a finegrained sandstone, originally calcareous. In the process of leaching the calcareous matter of specimens lying near the surface was dissolved and carried away, leaving only the molds; these, however, owing to the fine-grained character of the rocks, exhibit with great faithfulness the surface characters of the shells. Deeper in the same section is a tough calcareous sandstone, to which the shells adhere so strongly that attempts to extract them often tear away their external surface, making the specimens imperfectly represent the original surface characters. For this reason the molds express the surface characters, both external and internal, more accurately than do the shell specimens themselves.

External form of shell.-In external form the specific characters are the same as the generic but are in several particulars fluctuating. Hall remarks that the young forms "are sometimes longer than broad"; in figure 2a he illustrates " such a specimen (var. gamma) and in figure 3a a young specimen "of the ordinary form"; this one is broader than long (var. typicalis). The specimens from the fauna collected in the Harford Mills section show great fluctuations in the proportion of length to width; but no specimen (and there are specimens only 4 millineters in length) shows a form as narrow as that in Hall's figure 2a.

Some specimens from Harford Mills (var. alpha) are more extended laterally at the cardinal extremities than are any figured from the Hamilton; and some of them have sides sloping off with uncommon abruptness toward the front, giving the shell a subtriangular instead of the general normal quadrate form. For example, one specimen (Pl. I, fig. 47) of the Harford Mills faunule shows an extension of the hinge margin to 11 millimeters and a total length of only 7.3 millimeters; the sides of this specimen slope rapidly together toward the front, so that about halfway to the front the width is only 7.8 millimeters. This specimen, which may be called Tropidoleptus carinatus zeta, is the most extreme form known, but others show similar modifications. Another specimen (Pl. II, fig. 24) shows approximately straight sides nearly at right angles to the cardinal margin from the front to below the middle; and at the left-hand cardinal angle the margin of the shell expands for a millimeter or so in front of the end of the hinge, thus combining the characters of vars. typicalis and beta. But this is the only specimen in the lot in which the cardinal angle is rounded; in a few the angle may be as great, but in the great majority it is less than a right angle, and in a considerable number a broad mucronation appears. 
The average form in these respects of the specimens from Harford Mills is fairly well represented by figures $3 t$ and $3 w$ of Hall's plate ${ }^{1}$ of the Hamilton types, already referred to as Tropidoleptus carinatus alpha, and quite a respectable minority of the specimens have their lateral margins appreciably narrower at each successive millimeter from the cardinal angle to the front; in the majority, however, the sides are nearly parallel for about a quarter of the length toward the front. This element of form thus shows progressive modification toward the new variety zeta. The majority of Hamilton specimens, so far as I have examined them, hold a subparallel direction of the lateral slopes for approximately the mid-third of length of the shell. Many large specimens round off at the cardinal as well as the front angle of the shell; but they rarely show contraction of the lateral margins sufficient to throw the greatest breadth more than halfway from the cardinal to the front margin.

Thus, though it is apparent that the samples of the genus contained in zone No. 1 are relatively narrower in front and more extended proportionally at the cardinal border than the samples from the Hamilton formation, a rough estimate of the number of specimens in the sample (Hd. 13G, 1r) on each side of the mean development of the series indicates that the amplitude of fluctuation in respect to general form is approximately the same for the Hamilton and the zone No. 1. The mean has shifted about one-fifth of the total range of fluctuation toward the extreme represented by Plate I, figure 47 (Tropidoleptus carinatus zeta). No specimens in the zone No. 1 express the extreme rounded cardinal angle and broad quadrate form of the Hamilton type Tropidoleptus carinatus typicalis, and, so far as known, no specimens in the Hamilton attain the broad mucronated cardinal angle and sloping sides of the extreme forms of the zone 1 (Tropidoleptus carinatus zeta). Nevertheless the great majority (two-thirds, approximately) of the specimens from zone 1 correspond in form with specimens observed in the Hamilton formation.

Pedicle valve.-After critical comparison of the specimens of the sample faunule of the zone No. 1 with the descriptions and figures of those in the fauna of the Hamilton I do not discover any appreciable departure from the described characters of the general form elements of the pedicle valve. (See Pl. I, figs. 1-27.)

Brachial valve.-The brachial valves from the zone No. 1 (Pl. II, figs. 1-24) represent very closely the general form of the brachial valves described and figured for the Hamilton specimens. In the same stratum and grading into this series by imperceptible steps is another series (Pl. I, figs. 42-64) showing a departure from the described Hamilton characters in respect to the curvature of the shell. The Hamilton forms vary from nearly flat to broadly concave, and in all of them flatness begins at an extremely early stage of growth. I have failed to discover on any Hamilton specimens an initial convexity of the surface of the brachial valve. Nor (except for a few specimens that seemed to have been crushed) have I observed any Hamilton specimens in which there was a sudden change in the curvature of the shell.

The second selected set of brachial valves from the zone 1 (Pl. I, figs. 42-64), however, shows both an initial convexity and a natural geniculation, the angle of the bend facing inward and increasing the convexity of the shell. Several specimens (Pl. I, figs. 42, 43, 48, 55) show distinct initial convexity, ${ }^{2}$ though in these the convex part does not exceed a millimeter in length and beyond this the surface is flat. In one specimen (Pl. I, fig. 42) the convex part extends about $2 \frac{1}{2}$ millimeters from the apex. In another (Pl. I, fig. 44) it extends $4 \frac{1}{2}$ millimeters, approximately the whole length of the shell. In still another specimen (Pl. I, fig. 64) it is flat for about the same distance and then bends outward. In most all the shells in this set (Pl. I, figs. 42-64) a more rapid curvature outward begins within 3 or 4 millimeters from the apex. In one specimen ( $\mathrm{Pl}$. I, fig. 64) the geniculation is seen in its typical condition; for 4 millimeters from the apex of growth toward the front the surface is approximately flat; within the next 3 millimeters the shell curves abruptly and steeply outward, and for the last 5 millimeters the median plication is approximately straight, though having a slight concavity on the sides. The angle between these two nearly flat surfaces is about $120^{\circ}$. This tendency of growth is seen

\footnotetext{
1 Paleontology: Geol. Survey New York, vol. 4, 1867, Pl. LXII.

2 It must be borne in mind that all the specimens illustrated are molds of exteriors, and that convexity in the specimen is shown as concavity in the molds.
} 
in a less degree on nearly all the specimens of this set, though not so strongly marked as in the specimen cited (Pl. I, fig. 64). It is evidently associated with the narrowing of the lateral margins of the shell already referred to as characteristic of variety zeta and expresses a modification in the general form, not affecting all but showing to some degree on half of the specimens of this sample lot. Taking all the specimens of the lot together, I consider the character here indicated as a fluctuating variation in mode of growth. So far as my examination has extended, although Hamilton forms show fluctuation in the degree of concavity of the brachial valve, the normal is nearly flat and the peculiar geniculation is not expressed. Further search may reveal it, however. As an indication of evolution it is evident that there is increasing frequency and fuller expression of this modification in zone No. 1 than in the Hamilton. Here, as before, however (p. 37), the advance shown by comparison of the shell in the two stages of its history is but a fraction of the total range of fluctuation shown by the individuals of this single sample of the fauna found associated together in a space of a square foot or so of rock.

Surface characters. - In his description of the Hamilton species Hall stated ${ }^{1}$ that the simple rounded plications are "wider than the spaces between them." Examination of the surface form inclines me to think this difference is more apparent than real. The corrugations appear to be quite regular, the depression and elevation taking place at the same rate and making furrows quite uniform with the plications. The smoothness of the surface does give the effect of a sharp change from the illuminated plication to the trough of the dark depressed surface. The edge of the shadow if taken for the edge of the plication gives the effect, when the shell is held in certain angles to the light, of a narrow trough. However the character may be defined; I discover no appreciable difference in the width of plications between shells from the Hamilton and those from zone No. 1.

In number, however, the plications fluctuate, as was recognized by Hall in his description of the Hamilton form. ${ }^{1}$ In Hall's figures the number of observed plications runs as follows: $18,20,19,18$ (PI. LXII, fig. " $3 \mathrm{~d}$ " = 4), 32, 26, 17, 19, 21, 20, 21 (fig. 31 after mid-growth shows a splitting and thus doubling of the number of plications), 19,16,15, and 18 .

Fifteen plications to the shell is the least number expressed by the figures, and 18 to 20 appears to be the normal number. This may be more precisely defined by saying that samples of the pedicle valve from the Hamilton exhibit on the surface 8 to 10 plications on each side of the median plication. The fluctuation is chiefly due to greater or less distinctness of the plications at the cardinal angle of the shell. A triangular space on the cardino-lateral angle of the shell is smooth. In shells in which the plications are greater in number than the normal the additional plications are very faint and small and appear on the edge of this smooth area. In shells in which the plications are below the normal number the smooth surface is broadened. It is therefore a fluctuation as to the extent of surface affected by the corrugating process.

Examination of the samples of the zone No. 1 from Harford Mills shows the following number of plications: $17,13,16,18,14,14,16,17,16,16,19,18,15,16,20,17,18,17,17$, $15,16,22,17,17,17,16,17,21,18,22$. This series expresses an amplitude of fluctuation from 6 to 11 plications each side the median plication. This fluctuation covers the same mean as expressed by the Hamilton samples figured. There are, however, specimens from the Hamilton showing a greater number of plications (32 and 26), and I think that search in the Hamilton may show specimens with fewer plications.

The size of the shells of the zone No. 1 samples is noticeably less than the average size of the Hamilton figured samples. Nevertheless, a majority of specimens from the zone No. 1 show as many plications as do a majority of the specimens from the Hamilton. Moreover, the actual size of the plications for a width of six plications on each side of the center does not differ appreciably in the samples from the two stages. Nevertheless, the size of the plications does fluctuate. One specimen (Pl. I, fig. 17) has nine plications in a distance of 9 millimeters, horizontally, across the middle of the shell; another specimen (fig. 18) has about 101 plications in the same distance; and a third (Pl. I, fig. 26) shows 12. 
The fluctuation expressed by these measurements is associated with relative width of muscular scars and teeth plates; the size of the plications over the center of the shell also fluctuates correspondingly. This same kind of fluctuation is expressed in specimens from the Hamilton. It is evidently associated with the particular stage in the growth of the individual at which the rate of growth was accelerated, and thus reflects individual response to conditions of environment. These differences in individual expression of grow th rate are found in any set of samples and, so long (in the history of the race) as they show no signs of restriction, they are evidence of the continuity of racial characteristics. They should not, therefore, be selected as ground for specific distinction unless it is evident that they are around a new mode and, in the present case, I fail to discover any such change in the mode. The specimens of the zone No. 1 are, as above remarked, on the average, small compared with the typical Hamilton specimens, and I fail to discover any connection between size and the number of plications, except in so far as the minuteness of size makes it difficult to observe the extremely slight plications at the outer edge of the shells. Comparing small specimens with the corresponding initial part of larger shells there appears to be very close uniformity in the production of the plications. The enlargement of the central plication is a feature of the recurrent specimens as of the Hamilton species, and the occasional slight degree of enlargement is alike in both.

I find no specimen in the samples from the zone No. 1 that shows the bifurcation of plications figured by Hall in one specimen (Pl. LXII, fig. 31 ), ${ }^{1}$ here called Tropidoleptus carinatus epsilon. From the figure this appears to be more of the nature of an accidental sport than a characteristic of a normal individual; and if it were to recur it would not stand for specific mutation unless repeated.

The variation expressed by the author of the species in the statement that specimens from some localities show no appreciable "difference in size of the costæ" evidently refers to a lack of the special enlargement of the central plication noticed in most specimens. This variation is paralleled in the series of the zone No. 1 by numerous specimens ( $\mathrm{Pl}$. I, figs. 18, 26, 54, 64; and Pl. II, figs. 4, 24) and shows that this feature has remained in a fluctuating state in the descendants of the Hamilton species.

The concentric, fine lines crossing the plications, and the stronger imbrications are as conspicuous in the specimens from the zone No. 1 as in the Hamilton specimens.

Conclusions.-Thus, after critical comparison of all the characters selected by Hall as expressive of the Hamilton form, it is evident that there is not a single one of them which was not fluctuating in the Hamilton. The majority of characters used in defining the Hamilton species are in the same state of fluctuation in the zone No. 1. Roughly expressed, about fourfifths of the specimens in the zone No. 1 are strictly within the range of fluctuation observed in the typical Hamilton forms. Not more than one-fifth transgress the normal amplitude of fluctuation. These facts seem fully to authorize the conclusion that the representatives of the genus Tropidoleptus in the zone No. 1 are in direct genetic relationship with the Hamilton representatives, and that the race has not been modified in its long history sufficiently to remove it from the specific limits of the Hamilton species Tropidoleptus carinatus (Conrad).

STAtUs OF Fluctuating CHaRACTERS IN zONES NOS. 2 AND 3.

Specimens examined.-The facts bearing on the specific identity of the representatives from the zones Nos. 2 and 3 correspond to those already arrayed from the zone No. 1. The collections have all been closely examined, but few of them comprise. sufficient specimens to warrant detailed consideration, for a small faunule expresses only the particular variations among accidentally selected specimens and furnishes small ground for estimating their average or range. From the zone No. 3, at top of the Cayuta member of the Chemung, in Spencer Lake ravine (Wv. $1 \mathrm{~A}, 1 v v v$ ), a fine series was obtained from which may be gathered some idea of the morphologic expression of the genus at its highest known range. Seventy-five specimens were prepared and mounted on tablets for study-all of them molds of exterior or interior surfaces.

\footnotetext{
1 Paleontology: Geol. Survey New York, vol. 4, 186i, p. 407.
} 
External form.-The specimens attain greater size than any in the Harford Mills section. One specimen is 24 millimeters and half a dozen are 20 millimeters or more in width. The widest specimen from the Harford Mills section of the zone No. 1 is only 18 millimeters wide, and not over half a dozen specimens reach a width of 15 millimeters. In both sets small forms are present down to 4 millimeters broad; and several still smaller ones are in the Harford Mills set.

The samples from the zone No. 3 do not depart to so great an extent from the Hamilton specific type as do some specimens from the zone No. 1 . Several specimens show a cardinal length not equal to the greatest width of the shell, and rounded cardinal angles (var. beta) are not common. The variety with angular cardinal wing and sloping sides, contracting forward (var. alpha), is, however, present. The elements of form fluctuate in the same way as in the Hamilton samples; but so far as evidence of the samples goes, the range of fluctuation is greater in the specimens from the zone No. 1 than in those of either the Hamilton or the zone No. 3. This may be interpreted as indicating that these variations are continuously and purely fluctuations, that is, plastic characters showing no appreciable tendency to settle down into uniformity.

Plications.-The number of plications reaches a higher average in the samples from the zone No. 3 than in those from the zone No. 1. This may be expressed by stating that the number of specimens in which the number of plications on each side the median plication exceeds eight is greater in the zone No. 3 than in the zone No. 1. One example-the mold of the exterior of a brachial valve-shows 26 plications. Another specimen-a pedicle valve-shows 26 plications also. These latter numbers do not exceed those observed on Hamilton specimens, but they do exceed those on any specimen discovered in the lot from Harford Mills.

This greater number of visible plications does not mean a corresponding diminution of size of the plications over the central part of the shell; the increase in number arises from an extension of the visible plications slightly farther out on the cardinal wing, which, as already stated (p. 40), at its extreme is always flat and without visible wrinkling of the surface.

Brachial valve.-The rather sudden change in direction of the curvature of the surface of the flat to concave brachial valve (previously spoken of as geniculation; see var. zeta) is observed on the specimens from the zone No. 3, but it is uncommon and is less pronounced than in selected examples of the lot from Harford Mills. Specimens 41, 30, and 31 show the normal flat surface; specimens 43 and 45 show the geniculation; specimen 40 shows the initial convexity with reversal to concave and succeeding flatness of the surface. ${ }^{1}$ The feature is well expressed in the series from Harford Mills (Pl. I, figs. 42 and 43). These several characters of the brachial valve are also expressed by the Hamilton examples.

Conclusions.-The above comparisons of the representatives of Tropidoleptus from the Upper Devonian zones in the Portage and Chemung formations with the typical representatives of the race in the Hamilton do not show the evolution of any strictly new characters. Every particular in which the individual specimens are observed to differ from the typical forms of Tropidoleptus carinatus of the Hamilton is at the utmost a slightly accentuated expression of a character known to be in a fluctuating state in the Hamilton epoch. The extreme amplitude of the fluctuations expressed by the extreme specimens of these later stages is in no observed case greater than one-fifth of the fluctuation known to be expressed by Hamilton samples of the race. The race, therefore, shows its identity in the several separate zones as clearly by the constancy in the amplitude of its fluctuating variations as by the constancy of its more uniformly expressed specific characters.

\section{GENUS RHIPIDOMELLA.}

OCCURRENCE:

Specimens of the genus Rhipidomella have been detected in 88 of the 1,411 individual collections of faunules examined from the Watkins Glen and Catatonk quadrangles. These are distributed by 15-minute quadrangles as follows: Apalachin, 2; Dryden, 21; Elmira, 4; Harford, 33; Ithaca, 3; Owego, 4; Watkins, 0; Waverly, 21. By zones these samples are

1 The numbers in this sentence refer to the numbers on the specimens from locality $W_{v} .11,1 v v v$, not figured in the present paper. 
distributed as follows: Zone of the Ithaca member, 1 ; zone No. 1, 59; zone No. 2, 10; zone No. 3, 18.

The faunules listed above are the individual local collections made and recorded in the field. When these collections were studied in the laboratory the separate lots from contiguous strata found to contain the same fauna were for individual sections combined and treated as a single faunule, reducing the number of samples from 88 to the 42 sample faunules containing Rhipidomella as recorded in the table ooposite page 32 .

\section{SCOPE OF INVESTIGATION.}

On account of the considerable range of fluctuation in the characters expressed by the shells of Rhipidomella, the genus was selected for exact measurement in order to test the actual genetic relationship among its representatives in the several successive zones, and also in order to discover, if possible, the law of evolution which such a genus might express when examined critically at several successive points in its history.

The results of this investigation proved of such deep interest, biologically, that I wrote a special statement of the facts under the title "On the persistence of fluctuating variation illustrated by the fossil genus Rhipidomella" and read it before the December (1909) meeting of the Paleontological Society. ${ }^{1}$ In this place I will only repeat the facts then developed that bear directly on the discussion of the recurrence of the Hamilton fauna, many of the more interesting details being not particularly pertinent to the present discussion.

The evidence obtained from the study of Rhipidomella bears on the problems of recurrence in two ways: (1) It signifies a genetic relationship between the representatives of the genus at the separate stages in its life history represented in the several successive recurrent zones; and (2) it bears evidence of the integrity of the fauna during the long period of time represented and thus throws light on the actual migrations back and forth of the fauna whose continuity is thus established.

SELECTION OF SPECIMENS.

For the purpose of the special investigation, I gathered a series of samples of the genus Rhipidomella as expressed in five stages of its history, collecting all of them from outcrops in central New York, within 50 miles of the city of Ithaca, from .(1) The Hamilton formation; (2) the recurrent zone in the Ithaca shale member of the Portage formation; (3) the recurrent zone No. 1, in the Enfield shale member of the Portage formation; (4) the recurrent zone No. 2 , in the Cayuta shale member of the Chemung formation; (5) the recurrent zone No. 3, at the top of the Cayuta shale member of the Chemung formation. Twenty specimens were obtained from one locality of the Hamilton formation; 24 from two localities in the Ithaca member; 115 from seventeen localities in the zone No. 1; 40 from six localities in the zone No. 2; and 76 from nine localities in the zone No. 3.

To complete the series I added some good representatives from the Hamilton formation and from the Ithaca member of the Portage formation that were contained in the Cornell University collections. These, with the more complete series in the United States Geological Survey collection, selected from the special collections of the Watkins Glen and Catatonk quadrangles, constitute 35 sample sets. Altogether these sets contain 275 specimens in sufficiently perfect preservation to furnish exact measurements of several different elements of form which are capable of minute comparison with each other.

\section{MEASUREMENT OF SPECIMENS.}

CHARACTERS SELECTED.

These 275 specimens were carefully prepared, mounted on tablets, and numbered. Measurements were made with vernier calipers reading to 0.1 millimeter.

The following characters were subjected to measurement: $\mathrm{L}$, the length of the shell from umbonal apex to middle of front margin; $\mathrm{W}$, the width of the shell at the point of its greatest width at right angles to the line of length measurement; $L^{\prime}$, the length of the muscular scar of the interior of the pedicle valve; and $\mathrm{W}^{\prime}$, the width of the muscular scar of the pedicle valve. 
These four characters were chosen as offering the most satisfactory mathematical expression of the individual form elements of the shell capable of reduction to a common scale; and in making the measurements it was noticed that they do give a fair expression of the individual differences among the specimens compared.

\section{RATIO INDEXES.}

The samples from each lot differ considerably in actual size, owing to differences in the individual growth of the specimens when they were buried; and in order to eliminate these differences three ratio indexes were derived from the combination of measurements to express on the same scale the form characteristics of the specimens. These ratio indexes I represented by the symbols $R^{1}, R^{2}$, and $R^{3}$.

$\mathrm{R}^{\mathbf{1}}$ is the ratio index of the shape of the shell; that is, it is the proportionate width of the shell wnen the length is considered to be 100 . It is obtained by dividing the width by the length and multiplying by 100 .

$\mathrm{R}^{2}$ is the ratio index for the size of the muscular scar of the pedicle valve; that is, it is the proportionate length of the muscular scar when the length of the shell is made 100.

$R^{3}$ is the ratio index for the shape of the muscular scar of the pedicle valve; that is, it is the proportionate width of the muscular scar when the length of the scar is made 100.

In discussing the characters of Spirifer marcyi (see p. 58) I applied the method used by Gosselet in measuring Spirifer verneuili, giving to the ratio index for each dimension a small letter instead of $R^{1}, R^{2}, R^{3}$, etc. Thus, using $L$ to indicate length in millimeters, $l=$ the index value 100 for length; width in millimeters is marked $W$ and its ratio index $w=\frac{W}{L}=\frac{W}{100}$. The explanation of the method of obtaining the ratio values is given in detail on pages $56-58$. The method is an improvement on that above used, but the latter is retained here because it was used in the original publication of the facts.

\section{SHAPE OF SHELL (EXPRESSED BY INDEX $\mathbf{R}^{1}$.)}

From the shape of the shell as expressed by the ratio index $R^{1} I$ find great differences among the individual specimens. The extreme difference in the value of the ratio index $R^{1}$ for the 275 specimens measured is 74.4 (147.8-73.4), both of the extreme forms being found in the faunules of the zone No. 1.

The average value of $R^{1}$ for the 20 specimens (picked out of a large series of specimens from a single locality in the Hamilton, without consideration of specific values, for the purpose of getting an average expression of the fluctuation of form in the Hamilton) is 111.9.

The average value of $\mathrm{R}^{1}$ for the type figures used by Hall in illustrating the five species described by him from the Hamilton formation in New York State is 111.04.

The average value of $R^{1}$ for the total 275 specimens from the five zones (Hamilton formation, Ithaca member, recurrent zone No. 1, zone No. 2, and zone No. 3) is 108.2.

The average values of $R^{1}$ for the specimens from each of the zones are: Hamilton formation, 111.9; Ithaca shale member, 108; zone No. 1, 109.3; zone No. 2, 105.6; and zone No. 3, 108.6. The extreme difference between the smallest and greatest average value by zones is 6.3 , and the extreme difference between the smallest and greatest average value by species in the Hamilton, as figured, is 6.1. These facts when tabulated appear as follows:

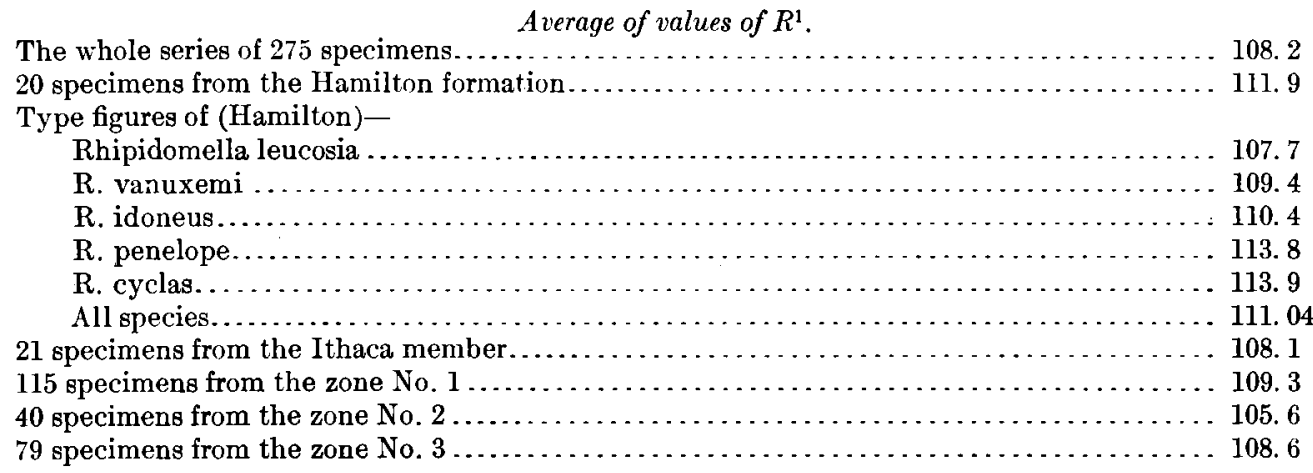


From this table it is evident that the average shape of the shell differs by less than 10 per cent by whichever of the above 12 methods the specimens are grouped. The smallest average (105.6) is that of the 40 specimens from the zone No. 2. The largest average (113.9) is that for the species $R$. cyclas, and the difference between these extreme averages is 8.3 . The averages for the several type figures range from 107.7 (Rhipidomella leucosia) to 113.9 (R. cyclas), showing a difference of 6.2 .

In other words the greatest difference expressed by the average values estimated by stages and by sequence in time exceeds the difference expressed by the average of recognized species of the Hamilton by only 2.2 per cent of the length of the shell.

To appreciate the importance of the above statement it is necessary to bring out the amplitude of fluctuation expressed by the specimens in each group, as follows:

Amplitude of fluctuation in the value of $R^{1}$

\begin{tabular}{|c|c|c|c|c|}
\hline $\begin{array}{l}\text { Number } \\
\text { of speci- } \\
\text { mens. }\end{array}$ & & Least. & Greatest. & $\begin{array}{l}\text { Ampli- } \\
\text { tude. }\end{array}$ \\
\hline $\begin{array}{r}275 \\
20\end{array}$ & $\begin{array}{l}\text { The whole series..................... } \\
\text { Hamilton formation............ } \\
\text { Type figures of (Hamilon) }\end{array}$ & $\begin{array}{r}73.4 \\
104.5\end{array}$ & $\begin{array}{l}147.8 \\
118.2\end{array}$ & $\begin{array}{l}74.4 \\
13.7\end{array}$ \\
\hline & Rhipidomella leucosia .... & 103.5 & 112 & \\
\hline & R.idoneus ... & $\begin{array}{l}107 \\
107\end{array}$ & $\begin{array}{l}11.8 \\
113.8\end{array}$ & $\begin{array}{l}4.8 \\
6.8\end{array}$ \\
\hline & R. penelope . & 106.7 & 121 & 14.3 \\
\hline & $\begin{array}{l}\text { R.cyclas.... } \\
\text { All species.. }\end{array}$ & $\begin{array}{l}110.8 \\
103.5\end{array}$ & $\begin{array}{l}117.1 \\
121\end{array}$ & $\begin{array}{r}6.3 \\
16.5\end{array}$ \\
\hline 21 & Ithaca member.... & 99.2 & 125.5 & \\
\hline & Zone No. $1 \ldots$ & 73.4 & 147.8 & \\
\hline $\begin{array}{l}40 \\
79\end{array}$ & $\begin{array}{l}\text { Zone No. 2.. } \\
\text { Zone No.3. }\end{array}$ & $\begin{array}{l}91 \\
91.3\end{array}$ & $\begin{array}{l}119.5 \\
137.3\end{array}-5$ & $\begin{array}{l}28.5 \\
46\end{array}$ \\
\hline
\end{tabular}

From this table it appears that the difference expressed by the averages is smaller than the actual differences expressed by individuals arranged on any other basis than that of the artificial selection by which the species are defined. There are only three of the selected specimens representing the artificial specific groups of the specimens from the Hamilton for which the amplitude of fluctuation of the value of $R^{1}$ is not greater than the extreme difference between the average values. Moreover, when the five species are arranged in the order of the values of the ratio index $R^{1}$ (see table, p. 44) it appears that none of the successive differences is greater than four points and that only one of them is greater than two points. The least difference in amplitude of fluctuation (see table above) is 4.8 , and the least amount of lapping of one species over the next in order is 4.8. Expressed in another way, the fluctuation in the set of type figures showing the greatest degree of uniformity in respect to this index is greater than the difference in value between any two of the artificial species defined.

Examining again the type series of specific figures I find that the extreme difference in fluctuation among the five species into which Hall divided the Rhipidomella race in the Hamilton is 6.2 (Rhipidomella leucosia having $\mathrm{R}^{1}=107.7$ and Rhipidomella cyclas $\mathrm{R}^{1}=113.9$ ). (See table, p. 44.) If, now, the average value of this index by zones (that is, by successive stages in the history of the race) be taken, the extreme difference between the average mode for the several zones is 6.3, the greatest value being that for all the Hamilton types (111.9) and the least value that for the set of zone No. 2 (105.6), zone No. 3 showing a slight increase (to $R^{1}=$ 108.6). Thus it appears that the total amount of deviation (6.3) in the mode of this fluctuating character from the Hamilton to the zone No. 2 is but one-tenth of 1 per cent greater than the actual deviation (6.2) between the extreme specific groups in the Hamilton. In the specimens of the recurrent zone No. 3 this difference $(111.9-108.6=3.3)$ is reduced to little over half the difference expressed in the Hamilton representatives of the genus.

The phylogenetic change in value in the mode of this fluctuating character is in the general direction of diminishing the mathematical value of the index $R^{1}$. This means that the form of the shell is narrowing. A study of the ontogeny of the shells (comparison of embryonic with adult forms) shows that, in normal growth of the individual, the direction of change is the same, the ratio index $R^{1}$ being greater for the young than for the adult form of the same shell. Also, comparison of the characteristics of the Silurian species of the genus with those of the 
Carboniferous species shows a similar trend in the form of the shell in the phylogeny, or life history of the race. This fact is exhibited by comparing the values of $R^{1}$ in two characteristic Silurian species with its values in two characteristic Carboniferous species. In Rhipidomella circulus (Clinton formation) $\mathrm{R}^{1}=117.3$, and in Rhipidomella hybrida (Niagara group) $\mathrm{R}^{1}=116$, an average of 116.6 for the Silurian. In Rhipidomella pecosi (Marcou) $\mathrm{R}^{1}=86.2$, and in Rhipidomella penniana (Derby) $\mathrm{R}^{1}=87.5$, an average of 86.8 for the Carboniferous.

The deviation in mode expressed by these two types at the earliest and latest stages in the life history of Rhipidomella is $116.6-86.8=29.8$. Or, expressed in terms of $R^{1}$, the change in form expressed by the race during its known life history from the Silurian to the Pennsylvanian series of the Carboniferous is approximately 30 per cent in the same direction, as indicated by growth stages in the ontogeny of the individual. About one-fifth of this deviation in mode is expressed by the series from the Hamilton to the Chemung. This total movement of the mode of fluctuation is, however, doubled by individual specimens in zone No. 1 ; it is exceeded by individuals from zone No. 3; it is nearly equaled by specimens from both the zones of the Ithaca member and zone No. 2; and half of it is expressed by 20 specimens from a single locality in the Hamilton.

SIZE OF MUSCULAR SCAR OF PEDICLE VALVE (EXPRESSED BY INDEX R2).

The statistics of ratio index $R^{2}$ are based on the measurement of 142 specimens showing the muscular scar on the interior of the pedicle valve.

The average values of $R^{2}$ for specimens from each of the five stages are: Hamilton formation, 60.7; Ithaca shale member not represented; zone No. 1, 64.8; zone No. 2, 63.2; zone No. 3, 64.7 ; all stages, 64.1 .

To judge these figures correctly, it is important to consider the amplitude of fluctuation of $\mathrm{R}^{2}$ for the several lots:

Amplitude in the value of $R^{2}$ by zones.

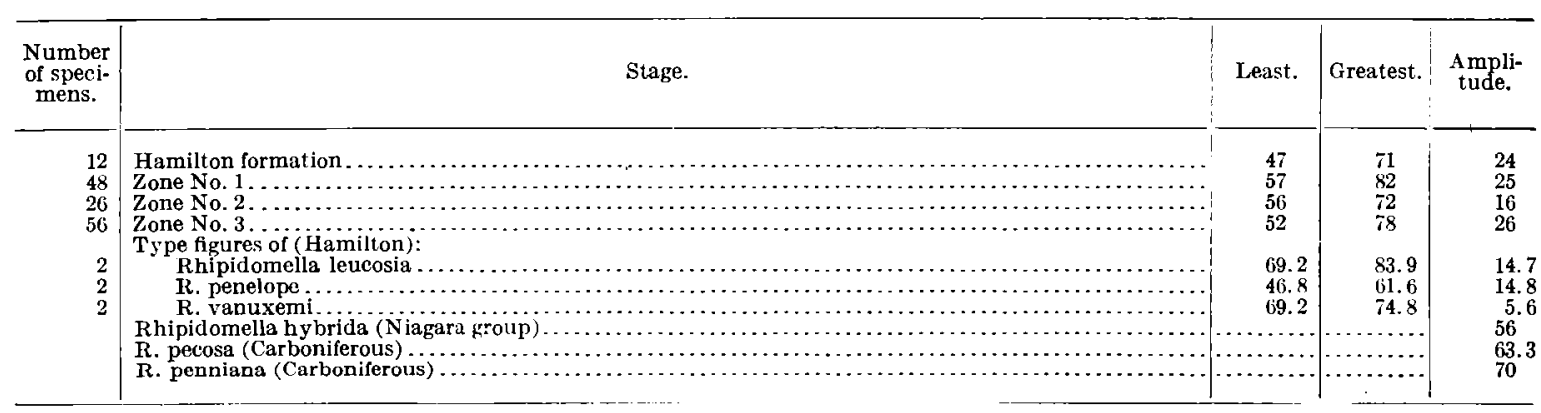

Comparison of the figures in the table above demonstrates that:

1. The difference in average value of $\mathrm{R}^{2}$ for a typical Silurian species $(R$. hybrida) and a typical Carboniferous species (R. penniana) is $14(70-56), \mathrm{R}^{2}$ being smaller by 14 per cent for the Silurian than for the Carboniferous species.

2. The average value (64.1) of $R^{2}$ for the Devonian representatives of the genus is intermediate between its values for the Silurian and Carboniferous specimens.

3. The range of fluctuation in the value of $R^{2}$ in each and every sample zone exceeds the total difference between the average values of the Silurian and Carboniferous types.

4. In only one Hamilton species (Rhipidomella vanuxemi) is the fluctuation shown in the type figures less than the total difference between the smallest Silurian and greatest Carboniferous extremes.

5. The difference between the proportionate sizes of the average muscular scars of the samples from each zone $(64.8-60.7=4.1)$, is less than that expressed by two selected type specimens of the species $R$. vanuxem $i$ which by the author of the species is recognized as showing the least fluctuation in this character of all the species of the Hamilton. Each of the other species for which selected figures are given, $R$. leucosia and $R$. penelope, show a difference three times as great. 
Here again the laws expressed by the index $R^{1}$ are found to prevail. The fluctuation in the value of $R^{2}$ for the genus throughout the successive stages in its life history represented in the recurrent zones is less than the fluctuation recognized as legitimate within each artificial specific group in the Hamilton; its value is intermediate between Silurian and Carboniferous types; and the general trend of its modification coincides with that expressed in the evolution of the race in general.

\section{SHAPE OF MUSCULAR SCAR OF PEDICLE VALVE (EXPRESSED BY INDEX R${ }^{3}$ ).}

The fluctuation in the shape of the muscular scar is much greater and more irregular than is that of the other characters here dealt with.

There are in evidence 142 specimens. The range of difference in the value of $R^{3}$ is from 75 to 127 , a difference of 52 points. The average in all sets is within a few points of 100 ; but the individual specimens differ widely. The type figures of $R$. vanuxemi differ in value of $R^{3}$ from 65 to 108.2, or 43.2 points; the three of $R$. penelope differ less-by only 7 points $(101-108)$; and the two of $R$. leucosia differ by only 2 points $(87-85)$.

The range in value of $R^{3}$ for specimens by zones follows:

Range of $R^{3}$ by zones.

\begin{tabular}{|c|c|c|c|c|}
\hline $\begin{array}{l}\text { Number } \\
\text { of speci- } \\
\text { mens. }\end{array}$ & Stage. & Least. & G reatest. & Range. \\
\hline $\begin{array}{l}13 \\
42 \\
24 \\
57\end{array}$ & 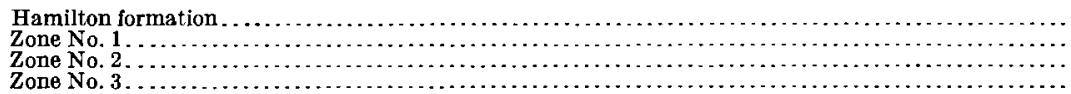 & $\begin{array}{l}89 \\
75 \\
76 \\
85\end{array}$ & $\begin{array}{l}110 \\
114 \\
1127 \\
116\end{array}$ & $\begin{array}{l}21 \\
39 \\
51 \\
31\end{array}$ \\
\hline
\end{tabular}

These values of index $R^{3}$ are, however, too widely scattered to give them much value in generalizing. Each sample set shows considerable fluctuation; almost every set, including two or more specimens, shows as much as 10 points deviation; almost every set of half a dozen specimens reaches 20 points; and in only a few faunules are any two of the specimens less than a full unit apart. The statistics, therefore, of this factor are too scanty to permit any conclusion other than that the fluctuation in the value of $R^{3}$ is great and shows no definite tendency to gather into separate specific groups.

The available type figures of the three described Hamilton species show that the muscular scar ratios $\left(\mathrm{R}^{3}\right)$ of two of the types of $R$. leucosia and one of the types of $R$ : vanuxemi differ by 6 points; the other types of $R$. vanuxemi and two of the three types of $R$. penelope differ by 2 points; and the two types of $R$. vanuxemi differ by 18 points. It follows that if the type figures represent real specific groups this character fluctuates to three times as great an amount within the species of $R$. vanuxem $i$ as either of the other species fluctuates away from $R$. vanuxemi.

Conclusions.-The evidence thus derived from a minute examination of the characters expressed by representatives of the genus in the recurrent faunal zones confirms the general hypothesis above stated regarding these faunas-(1) that a genetic relation exists in the several zones among the representatives of each repeated genus; and (2) that the faunas to which they belong do recur, and that migration did take place outward from and back again into this area at the three stages expressed by the recurrent zones Nos. 1, 2, and 3.

\section{SPECIFIC DISCRIMINATION OF RHIPIDOMELLA. ARTIFICLALITY OF PRESENT DISTINCTIONS.}

The specimens figured on Plate III (mostly the interior molds of pedicle valves) furnish a series of forms which differ in almost every detail but which, nevertheless, when taken in connection with their associates in the same faunules at different geologic horizons, impress me, and I think must impress every observant paleontologist, as being closely genetically related in the Hamilton and in each of the recurrent stages in the Upper Devonian.

The forms are so conspicuously different, no two being strictly alike, that at first one might regard each as representing a separate species, or at least a separate variety. But after a 
thorough study of the whole series of which these are a few samples, one becomes convinced that they are all intimately related genetically and that throughout their history they never break up into pure lines or "genotypes," but maintain throughout a blending of strains expressed in constant fluctuation of particular characters. Investigation shows that the characters by which Hall differentiated the Hamilton species are so constantly fluctuating in every set of specimens, whether selected on a basis of fauna, formation, or stage, that they can not be regarded as an expression of any genetic differentiation of the specimens compared. The elements of form on which the discrimination of the Hamilton species has been chiefly based so run together in any large series of specimens that one is compelled to regard the divisions as artificial.

The form which approaches nearest to the mean of the several fluctuating elements is Rhipidomella vanuxemi; the wide form with low beak is $R$. penelope, if large, and $R$. cyclas, if small; the narrow form with produced beak and extended cardinal slopes, throwing the greatest width toward the middle of the shell, is $R$. leucosia. The characters upon which $R$. idoneus are based are different from those here selected for comparison. These specific terms are useful to those who want names by which to classify collections, but they will require stretching to enable them to cover all the specimens that will be found in any good-sized collection from the Hamilton or from later rocks.

POSSIBLE MEANS OF DISCRIMINATION.

On the other hand, any classification based on the relative size, the shape, or the structure of the muscular scar of the pedicle valve will necessitate an entirely different distribution of the specimens, as may be seen by the figures on Plate III.

Some of the differences in characters which on theoretical grounds might be supposed to be uniform within the same genus are considered below.

Pedicle area.-The triangular area is exhibited on numerous specimens. In Plate III it appears clearly on figures $1,2,3,8,11,15$, and 18 and its anterior part on figures 13 and 17 . In size it bears a fairly uniform relationship to the general muscular platform. Its length is evidently directly associated with the elongation of the beak; in narrow forms (such as fig. 11) it is longer than in specimens with low umbo (fig. 18). It furnishes, however, small basis for differentiating the varieties in this series.

Hinge teeth.-The size and direction of the hinge teeth is quite uniform in Rhipidomella; the angle they bear to each other is coordinate with production of the beak above the cardinal margin; and, as the ridges bounding the muscular scar are continuations of their bases, the angle they make with each other is less in specimens (see figs. 3 and 15) in which the scar is relatively narrow than in those (see figs. 13 and 14) in which the scar is broad. The sides of the muscular platform in the posterior portion are in a general way parallel to the sides of the cardinal slopes of the shell, indicating a general coordination between the muscular scar and this form of the shell.

Median septum.-The specimens figured differ considerably in size, width, and longitudinal extension of the ridge separating the two main areas of the muscular scar. In figure 1 the anterior adductors are set deeper into the shell substance than are the diductors; though the posterior adductor is on a slight septum, it is still not raised above the main surface of the diductors; the septum extends forward into a slender ridge which is set, in a broad groove.

In the specimen shown in figure 2 the posterior adductors, though small in size, are in depressions of the shell; the median septum begins between them and extends forward as a thin sharp ridge to the front rim of the diductor, where it stops abruptly. In the specimen shown in figure 3 (also from the Hamilton fauna) the anterior as well as the posterior portions of the adductors are upon a septum the posterior part of which is strong but not wide. In the specimens shown in figures $4,6,10,11,13,17$ two strong ridges start from the outer sides of the anterior adductors, separating them from the diductors; these ridges meet in front of the anterior adductor and form a strong septum which separates the interior lobes of the diductors and terminates at their front rim. In figure 11, as in figure 3 , and to some degree in figure 13, the anterior portion of the anterior adductor is shown as elevated on the back of this septum. 
In figure 18 (specimen from zone No. 3) the septum is shown to divide the anterior lobes of the adductor; though well developed, it is low and broad and shows two slight grooves diverging slightly as they pass forward and reaching nearly to the front of the shell. Figure 7 (specimen from zone No. 1) shows a similar modification of the septum.

Muscular scars.- The anterior adductor scars differ markedly in size and form, as will be noticed on comparison of figures $2,4,6$, and 18 . The posterior scar may be narrow and simple, as in figure 2, or broad and extended forward, as in figures 18 and 7 and to some degree also in figures 1 and 11 .

The diductor scars differ greatly in shape, size, and subdivision into lobes. The form more frequently found is narrow behind, with nearly straight sides following forward from the teeth plates, expanding fan-shape, and regularly rounded in front (figs. 1 and 10). This form is modified by both the contraction of the sides and the elongation of the median lobes. The median lobes are generally more strongly depressed in the shell substance, and in many shells are elongated beyond the front rim of the general scar, as shown in figures 4 and 13 and to an extreme in figure 2. The subdivision into lobes is also not uniform; in some specimens a few strong lobes are seen (fig. 13); in others the subdivision is irregular and is not strongly marked (figs. 1 and 7). Few lobations are quite symmetrical and some of them (figs. 6 and 15) show evidence of abnormal growth.

Interior markings.-In several figured shells, and in not a few in the collections examined, the molds show evidence of ridges that have developed in the substance of the shell and that have affected the form of the muscular scars; evidently these are abnormal growths. (See figs. 8,6 , and 13.)

Difference in convexity of valves.-Normally in specimens of good size from the softer shales of western New York the pedicle valve of Rhipidomella vanuxemi is more or less convex. In the more sandy shales of the Hamilton in central New York it is less convex and in some specimens is nearly flat. In some of the broader forms to which the name $R$. penelope is applied the pedicle valve is slightly concave toward the front.

The specimens here figured from the Hamilton are slightly convex but not so much as are the figured specimens of typical $R$. vanuxemi from the soft mud shales of the west. Figures 10,13 , and 18 show shells slightly concave in the front part of the valve; figures 11 and 15 preserve the convexity to the front.

The flattening of the pedicle valve with corresponding increase in convexity of the brachial valve shown by the two figures 13 and 14 (two sides of the same specimen) is characteristic of the later recurrent specimens, showing an accumulating tendency toward that modification. The change is slight and gradual and does not affect in equal degree all specimens in each ascending zone. Nevertheless, an increasing number of flat or slightly concave forms appear in the higher zones, whereas in the Hamilton this modification passes beyond a slight flattening of the front portion of the pedicle valve only among wider and larger forms such as would be called $R$. penelope.

Thickening of the shell.-In the successively higher zones an increase in the strength of the shell is manifested not only by the actual thickness exhibited in molds but in the deeper cutting of the muscular impressions, the larger teeth, and the absence of the surface lines on molds of the interior. These surface lines are seen in the later recurrent specimens only at the outer rim of the shell (figs. 18 and 7), whereas in the Hamilton specimens preserved in the same way they are seen over the entire surface of the interior outside the muscular scar (fig. 2).

This feature is also expressed in the rigidity of the shells. Few specimens from the zone No. 3 are crushed or flattened, though laterally they may have suffered distortion of form, resulting from the movements of the rock after their fossilization. Many of the Hamilton and Ithaca forms are flattened. (See fig. 5.)

The increased thickness of the later shells is accompanied in numerous specimens by abnormal deposits of shelly matter inside the shells. (See figs. 8 and 13.) Whether this

$$
67437^{\circ}-\text { No. } 79-13-4
$$


apparent tendency to excessive formation of shell substance is an evidence of the evolutional old age of the race, or is an adjustment to a more strenuous environment, or is merely the result of the sorting out of the stronger shells by the heavier action of the waves bringing them to the state of rest, is difficult to determine.

\section{CONCLUSIONS.}

The great variability in all the elements of form of these shells of Rhipidomella, not only in the Hamilton but at each of the recurrent zones in the Upper Devonian, makes me hesitate to increase the specific nomenclature by proposing new names for each separate combination. for to do so would require an extraordinary number of divisions, whether they be classed as varieties or species. In my opinion they should be held together for the present and for at least as much longer as will enable the paleontologist to grasp the idea which has been forced upon me as I have studied them, to wit, that they constitute a series of organisms which during their lifetime were genetically bound together by an indefinite amount of crossing and mixing and which in their successive appearances did not lose capacity to breed together. They show evidence of adjustment to environment in the fact that many of the sets from separate faunules, taken as a whole, show some local peculiarity of size or shape but yet retain flexibility of expression in the describable characters. Their characters can be satisfactorily explained only by supposing genetic relationship, and so long as all the characters by means of which species can be discriminated continue to fluctuate it seems impossible to consider that any of the observed differences have been permanently established. And if they are not permanently established (that is, if they remain fluctuating characters) any attempt to use them in discriminating zones or stages in geologic time will lead to unsatisfactory results.

\section{SPIRIFER MARCYI.}

DIFFERENTIATION.

In the final arrangement of the spirifers as expressed in Hall and Clarke's "Paleozoic brachiopods" "Spirifer marcyi is placed in a large group called "Ostiolati," with Spirifer ostiolatus Schlotheim and $S$. oweni Hall as types. The Ostiolati include spirifers such as $S$. audaculus, with smooth surface, and $S$. granulosus, with fine granulose pustules, but exclude Spirifer mesistrialis, which is placed in the group "Radiati," of which $S$. radiatus of the Clinton and other Niagaran formations is the type.

I do not propose here to discuss the merits of such a classification, but I do wish to call attention to the fact that, whatever species may be associated with Spirifer marcyi in a general subdivision of the genus, the forms recurring in the Upper Devonian, with all their fluctuating variations, are quite distinct from the striated form Spirifer mesistrialis found in the same formations but only very rarely associated with Spirifer marcyi in the same faunules; also, that all specimens of the recurrent $S$. marcyi forms, which are sufficiently preserved to show the minute surface characters, are marked by pustules and are distinct from the smooth-surfaced type of Spirifer audaculus.

In his definition of the species Hall recognized the decidedly fluctuating expression of many of the specific characters of Spirifer marcyi. ${ }^{2}$ In tracing it in the recurrent zones above the Hamilton the rather attenuated pointed beak, the relatively fine plications, the high area, and the peculiar surface markings are the more constant diagnostic features. Its great plasticity, however, in many elements of its morphology gives to the specimens of the race, as it appears in the Upper Devonian, a variety of expression which seems generic rather than specific. In fact, the difference, expressed by representatives of the race in single faunules, is much greater than the difference expressed in the same faunule by representatives of Rhipidomella, which has been distributed into five specific groups in the Hamilton epoch of its history. 
Hall stated in his original description that "in both valves the surface is marked by very fine elongate pustules which become crowded toward the front in old individuals. This gives a very marked and reliable character when preserved." These pustules furnish a means by which Spirifer marcyi may be readily distinguished from any other species in the Hamilton or Upper Devonian of New York, particularly from the $S$. audaculus-macronatus group, the members of which resemble it in general aspect, but have smooth surfaces without pustules. It is readily distinguished from $S$. granulosus by its form, by its finer plications, and by its rarer and more elongate pustules. It differs from Spirifer mesistrialis and its close allies in several respects, the latter having wider and more flattened plications and a linear arrangement of surface markings; in some of the higher representatives of $S$. mesistrialis the lineations appear to be interrupted but on close examination are found to be in continuous lines, whereas the elongate pustules of $S$. marcyi are not continuous but are distributed irregularly and interruptedly in the longitudinal direction.

\section{RECURRENCE BY ZONES.}

Spirifer mesistrialis appears abundantly in the Ithaca member of the Portage of the eastern part of the Watkins Glen and Catatonk quadrangles; and varieties of the same race are abundant in the Spirifer disjunctus fauna of the Cayuta member of the Chemung and continue to appear in the Wellsburg member after the disappearance of $S$. disjunctus. But it is extremely rare to find Spirifer mesistrialis associated with $S$. marcyi in the same faunule. The few faunules in which the two are gathered together are in the Tropidoleptus recurrent zone No. 3, at the top of the Cayuta member of the Chemung formation. Below, within a few feet of the recurrent zone No. 3, as shown in the Spencer Lake ravine section (Wv. 1A), both Spirifer disjunctus and $S$. mesistrialis are found in great abundance. I conclude that the Spirifer marcyi fauna was brought into the area suddenly and in rather full vigor at a time when the normal Chemung fauna was present in abundance, and that it almost but not entirely displaced the latter. The extent of the change which took place is shown by the fact that above Tropidoleptus zone No. 3 Spirifer disjunctus is extremely rare, if not entirely wanting; certainly in some sections no trace of it has been seen above that zone.

\section{OCCURRENCE BY FAUNULES.}

Among the 1,411 separate faunules collected in the area of the Watkins Glen and Catatonk quadrangles, 79 have shown the presence of Spirifer marcyi. In only 5 of these is the exact stratigraphic relationship to the Tropidoleptus recurrent zones in doubt; in the other 74 the species is actually associated with other representatives of the recurrent fauna at one of the three recurrent zones (Nos. 1,2, or 3), or else is within a few feet of such representatives, showing the time separation between the entrance of the two faunas to be not great. The faunules that are in doubt lie above the base of the Chemung in the Cayuta member. The fossils are numerous and most of them are continually repeated throughout the greater part of the Cayuta member, appearing wherever fossiliferous zones occur.

\section{FLUCTCATION IN SLCCESSIVE zONES.}

$$
\text { DEGREE OF FLUCTUATION. }
$$

The characters expressed by Spirifer marcyi are in several respects fluctuating. Their plasticity is indicated in the original definition of the Hamilton species, which shows their amplitude of fluctuation to be considerable. It continues to be great in the several recurrent zones, as shown by the specimens examined. These latter offer valuable evidence of modification in time, but can be made to express the facts only by close observation and minute measurement and comparison.

\section{FLUCTUATION IN ZONES NOS. 1 AND 2.}

The characters of the specimens in the recurrent zone No. 1 are more uniform than, and the specimens do not reach so great size as, those in the zone No. 2. In the zone No. 1 the pustules are, in general, more numerous than is customary upon Hamilton specimens, but this may be 
due in some degree to their smaller size; specimens of more normal type also appear. In the zone No. 2 the species appears in great abundance in some of the localities and shows considerable difference in its surface markings; specimens with the pustules far apart, as in the Hamilton species, are plentiful; others have closely arranged pustules (rarely seen in Hamilton specimens) distributed over the front surface of the fold and sinus. The Tropidoleptus zone No. 2 contains other specimens in which the surface appears to be almost if not quite free from pustules; and others in which they are very elongate though never strictly continuous in parallel lineations like those of Spirifer mesistrialis. In this zone the shells also exhibit considerable differences in form, size, and relative development of parts; some specimens show excessively high area with shortened cardinal margin; others have a high area with the cardinal margin greatly extended and mucronate; a lower flat form is produced by a great extension of the shells laterally. That the specimens indicate great variability of form but belong to a common genetic species is shown by the fact that these differences in the lesser details of surface and shape and in what may be called the general complexion appear among shells taken from the same stratum.

The interior characters of shells from the zone No. 2 also differ greatly. The strength and conformation of the muscular scars, the thickness and extent of the hinge plates, and all the morphologic characters expressed about the umbonal portion of the interior of the shell of the pedicle valve show great plasticity.

Among the plastic features unmistakable rudiments of the peculiar plates later developed as a syrinx in the genus Syringothyris appear on a few specimens. In its earliest form the syrinx appears as a pair of low short ridges on the inner face of the cross septum uniting the bottoms of the hinge plates near the apex of the cavity of the umbo. Comparison with typical specimens of Syringothyris shows these ridges to be the same which in Syringothyris develop into a tubular extension of the interior called the syrinx. In none of the specimens discovered by my collectors in the Watkins Glen and Catatonk quadrangles is this character developed beyond the stage of two parallel short plates extending inward from the inside wall of the transverse plate near the apex of the umbonal cavity. Its forward extent does not exceed a millimeter and its length from the point of the beak downward toward the center of the cavity of the shell is at greatest not over 3 to 4 millimeters. (See Pl. IV, fig. 10.) The remarkable fact, however, is that a few specimens showing this undoubted rudiment of the syrinx appear in faunules with specimens which are like them in other characters but which lack any trace of the syrinx. I examined every one of the perhaps 200 specimens in the collection, preserving the appropriate part of the shell, and found a dozen or so that possess this rudimentary syrinx. The character appears in only two or three specimens in a faunule; all the rest show the corresponding parts perfectly smooth. The zone No. 1, as well as the zone No. 2, shows a few specimens with the rudiment, but $I$ have not discovered it on any of the specimens from the zone No. 3. It is remarkable to find this apparent cessation of the anomaly, especially as the true Syringothyris, stratigraphically, follows in almost direct sequence above the zone No. 3; and I am inclined to think that its absence is due to failure to discover it rather than to its actual absence from the fauna. Future investigation will demonstrate the facts.

FLUCTUATION IN ZONE NO. 3.

Indications of the fluctuations exhibited in the highest Tropidoleptus zone No. 3 by Spirifer marcyi are noted below:

Specimens from faunule El. $2 \mathrm{G}, 1 a$, show the pustules on the front part of the sinus fine and close together but somewhat larger, more elongate, and more sparsely distributed on the sides of the shell. The form is wide and is not narrowly mucronate.

A specimen from faunule $\mathrm{El} .1 \mathrm{E}$ is above average size but the sides are not produced laterally. On this specimen the punctations, like those on the typical Spirifer marcyi, are rather numerous toward the front of the shell.

The specimens from faunule Wv. 1A, 1vvv, are large. Some of the larger specimens have the tops of their plications smoothed and flattened, apparently by erosion, and have very faint traces of pustules or none; others of smaller size show the pustules normal. (See Pl. V.) 
Large and massive pedicle valves are present. No specimens having the slightest trace of the rudimentary syrinx before mentioned are found in the faunule. The absence of pustules on many of the specimens gives a first impression that they are a modification of Spirifer audaculus or macronatus, but the occasional finding of the pustulated surface without other distinctive characters of the latter species leads to the conclusion that the smooth specimens have had their pustules removed by attrition before fossilization. In a few specimens broad low plications appear in the sinus or on the folds (see Pl. V, fig. 13); other specimens show this rudimentary development of plications along the center. The peculiarity of this mode of development is that the plications come over the edge of the fold and sinus from outside and are not developed from the center of the fold or sinus like the intercalated plications in Spirifer arenosus and $S$. disjunctus. In the latter species the central plications also are stronger and sharper than those near the edges of the fold or sinus.

Other faunules of the Tropidoleptus zone No. 3 not only contain specimens in which the pustules are elongate but have associated with them specimens with the shape, the wider plications, and the linear markings of Spirifer mesistrialis.

Specimens from Ap. 11E show typical Spirifer marcyi pustules that vary from the normal, elongate, and separate form to one in which they are finer and more closely distributed.

Specimens from Ap. 8G, 3, and Ap. 13L have beautifully preserved pustules of Spirifer marcyi type.

SUMMARY

Comparison of the samples from the several zones discloses that the representatives of the zone No. 2 show the greatest diversities in form and characters; those from the zone No. 3 show the greatest departure from the typical characters; and those from the zone No. 1 show the least diversity and the closest conformity to the type species of the Hamilton, except that they are conspicuously smaller than the typical Spirifer marcyi of the Hamilton. The series offers attractive problems for further research, particularly in regard to the origin of the characters by which the genus Syringothyris is differentiated. Spirifer marcyi is closely associated with Tropidoleptus and Rhipidomella in the recurrent faunules; its presence in the fossil faunules is a definite indication of recurrence, and evolutionally it constitutes a continuous line from the Hamilton Spirifer marcyi through the Upper Devonian varieties designated in the following pages to the typical representatives of the Mississippian genus Syringothyris.

LAWS OF EVOLCTION EXPRESSED BY THE GENS SPIRIFER MARCYI.

As so much has been said regarding the general characters of the gens Spirifer marcyi (to use Vaughan's term), ${ }^{1}$ as it appears in the successive recurrent zones of the Upper Devonian, it may be profitable to use the series of forms thus associated to elucidate some of the laws of evolution involved.

\section{EVOLUTION AND CLASSIFICATION.}

The paleontologist in classifying and identifying his fossil specimens is liable to overlook the evolutional factor always involved when specimens under examination belong to a zone below or above that from which came the typical species with which they are compared. Although the zoologist may recognize varieties and "mutations" in the De Vriesian sense, he has no call to consider the difference of form to which Waagen applied the term mutation. He includes under the same specific name organic bodies of widely diverse form because he has been able to trace in actual sequence the changes in form exhibited by the same individual as it develops from the embryo to the adult stage. The paleontologist, however, has available only the separate individuals represented by their fossilized hard parts, and his application of specific names must be based on the likeness of the characters these exhibit. In classifying such fossils he is therefore likely to class together only those specimens which agree in their morphologic

1 A. Vaughan defined "gens" as follows: "A gens or specific group may be considered to be the aggregate of all the species which possess, in common, a large number of essential properties, and are continuously related either in space or time," Quart. Jour. Geol. Soc., vol. 61, 1905 , p. 183. This term and conception was later employed by R. G. Carruthers in discussing the evolution of Zaphrentis delanouei, Quart. Jour. Geol. Soc., vol. 66,1910 , p. 523. 
characters and to give separate specific names to specimens which differ in form irrespective of their evolutional or historical relationship to each other.

It is evident, when attention is called to the fact, that such a method, though of practical value in labeling specimens for a museum, neglects one of the most important facts which the paleontologist alone can directly observe - the evolution of the race.

The morphologic development of the individual is so familiar that the fact is apt to be forgotten that the so-called specific characters of any particular organism are the characters it exhibits at its adult stage of development. Paleontologists of the preevolution stage based their nomenclature on such definitions alone. Studies in historical evolution are prevented from free progress by this nomenclature, and it becomes necessary to emphasize the fact that as knowledge of the details of paleontologic history increases evidence of progressive modification in form of the adult organism should be expected.

\section{NOMENCLATURE ADOPTED IN THIS PAPER.}

In the following study of Spirifer marcyi the nomenclature adopted is tentative. It may prove satisfactory for general application, or as knowledge along this line develops it may give way to some better method. If it were certain that observed differences in form are expressions of actual stages of evolution it might suffice to give them names indicative of successive stratigraphic zones in geologic sequence. My observations, however, make me uncertain as to whether the differences observed are permanently adopted stages of modification coincident with genetic evolution or are only temporary adjustments of fluctuating characters to changed conditions of environment.

In recording the facts, therefore, I here adopt an arbitrary system of nomenclature, which may be interpreted later (as the further evidence gathered may justify) without prejudice as to any particular hypothesis here adopted as to the cause of the modification.

\section{SPECIFIC IDENTITY.}

In citing among the species of each recurrent fauna of the present paper the same specific name I do not mean to convey the impression that the species thus cited has suffered no modification of its characters on passing from zone to zone. Where the same specific name has been used, I have intended to express the fact that the deflection from specific characters already exhibited by representatives of the species in its typical locality and horizon is not of such a nature or amount as to indicate evolution of any new characters not already expressed by representatives of the species selected for definition of its specific characters. The use of the same name implies more than that the later specimens are representatives of the same race as the earlier specimens. Modifications have taken place in the race during the long lapse of time between the successive stages in its history, and it is only when successive representatives express such uniformity of characters as will tie them all together within the range or amplitude of fluctuation of their characters at the first stage examined that they can be assumed to belong to the same continuous genetic race and can be referred to by the same specific designation. If a character appears which is not discoverable among the fluctuating characters of the earliest examined representatives of the group, that character differentiates the specimen under consideration from the original group in a specific way; and, although theoretically it may be assumed that the differentiation is a result of evolution within the genetic series, it is impossible to establish the validity of such hypothesis on the evidence; the differentiation may have taken place prior to the time represented by the individuals of the first set examined.

Although such presumable evolution may account for the differentiation exhibited in a series of different species appearing in successive geologic beds, such a presumption can not stand alone as basis for the establishment of the laws of evolution actually effective in geologic time. It is in the discovery of these laws of evolution and their establishment on observed fact that I am here interested.

It should be clearly stated that specific identity does not mean absolute uniformity of characters. On the contrary it is well established in all fields of natural history of organisms 
that no two individuals of the same species are absolutely alike in all their characters. The critical study of species is leading taxonomists everywhere to realize that the hard parts of organic bodies are not rigidly conformed to mere repetition of the characters exhibited by the hard parts of their parents but are expressive of a combination of (1) the hereditary plan of construction and (2) its adjustment to the individual experiences of the organism during the process of construction.

The degree of elasticity of application of its hereditary plan of construction is in each individual almost directly proportioned to its vigor or power to overcome obstacles to its living. The more rigidly the hereditary plan of construction is carried out by a growing organism, the more certainly will the stress of adverse conditions of environment result in the destruction of the race.

Hence it follows, as observed in nature, that a certain degree of elasticity in the construction of hard parts is common to all organisms. It is also observed that races which show the greatest vitality and are represented in geologic history by the longest line of descendants are decidedly plastic in the construction of their hard parts-particularly of those hard parts by which they come directly into relationship with the environment; that is, their external covering.

\section{CRITERIA OF CLASSIFICation.}

These characters are fluctuating; and, therefore, a species, instead of being defined by the characters of the precise form selected as typical by the original describer, should rather be defined by the amplitude of its fluctuations under varying conditions of environment.

It is proportionate development of parts in relation to some unit of measurement of the individual itself rather than the divisions of a standard foot rule that must be used in defining the characters of a gens which is undergoing evolution of form in successive stages of its existence.

To illustrate these and other principles the facts expressed by the form to which Hall applied the name Spirifer marcyi is a good example.

\section{HISTORICAL DISCRIMINATION.}

Spirifer marcyi belongs to that section of the genus Spirifer which has (1) a distinct fold and sinus; (2) numerous surface plications (15 or more on each side); (3) a form whose width at the hinge margin is 150 to 600 per cent of the length of the middle growth of the brachial valve; (4) an area whose height is not less than 25 per cent and may be 50 per cent or more of the length of the brachial valve; and (5) a pustulose surface. All five are positive characters.

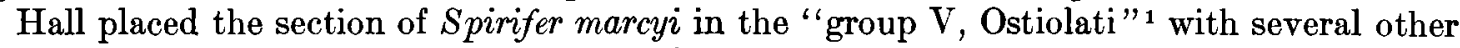
sections, all of which may be present in the Hamilton in the same stratum. The section, or gens, of Spirifer marcyi was, in general form and plications, already differentiated in Hamilton time by its pustulous surface from the gens to which $S$. audaculus belongs, the surface of the latter being free from evident pustules.

The section of Spirifer granulosus differs from S. marcyi in the more intensive growth of the middle part of its valves, producing more gibbous shells; in the overarching beak of its pedicle valve; in its wider fold and sinus and fewer plications; and in its generally lower area. The pustules of marcyi are scattered and somewhat elongate; those of granulosus are smaller and more crowded and less elongate. The plications of granulosus bear to those of marcyi the relationship of about six to eight in a given distance from the fold or sinus, measured in the middle part of the surface of the shell across the plications. The pustules are not uniform on either form in the Hamilton; some specimens of granulosus show them sparsely distributed over the surface, but most specimens show them closely distributed; a few marcyi show them minute and closely distributed, but the majority show them sparse and elongate. After the Hamilton epoch the particular granulosus combination of characters ceases; but the pustules of the granulosus type become more frequently associated with the other marcyi characters. 
The forms called by Hall Spirifer aspera and S. parryana are closely related to S. r.arcyi; but the differentiations expressed by these forms from Iowa signify a separate line of evolution from the race in the New York Basin represented by Spirifer marcyi.

DIFFERENTIATION BY FLUCTUATING CHARACTERS.

DEGREE OF FLUCTUATION.

Organic bodies may be classified in many ways, each of which may have particular fitness for a particular purpose. In the present discussion the chief purpose is to discover the relation of morphologic characters to time and place. If morphologic characters were uniform for a large number of individuals of the same place and time, and if their characters differed uniformly either at other places or at other times, the ordinary method of applying specific names would be satisfactory and useful.

But morphologic characters have no such rigidity of expression in nature. They fluctuate not only everywhere but through all time, and these fluctuations seem to affect all the hard characters of an organism, such as are alone in evidence in paleontologic series.

The so-called taxonomic rank of the characters is more a matter of definition than of degree of plasticity. One group of organisms is defined as quadrupeds, another as decapods, another as hexapods. The number of appendages is uniform for a great number of differently constructed organisms. The likeness and uniformity is in the number, not in the details, of form, and for purposes of classification it is convenient to give higher rank to those characters which are more general in relation to the plan of construction and to consider as secondary characters which are of subordinate relation.

Whatever the taxonomic rank, however, the morphologic relations of the structures are plastic, the degree of plasticity being almost directly coordinate with the influence of the particular structure on the vital economy of the organism. Complete rigidity in a structure is in a high degree evidence of its small influence in the organic activities of an individual; and great plasticity among representatives of the same species in the same time and place is evidence of large influence in the same respect. This seems to be a general law in the morphology of organic bodies.

This evident correlation between plasticity and organic vigor serves as a guide both in differentiating and in grouping together organisms when the chief object in view is to discover by means of morphologic characters what influences time and place have exerted in determining the particular form of the organisms studied. In classifying the spirifers it is of first importance to select such characters as express a high degree of plasticity. Thus it is sufficient to select only those forms which express the generic characters of the genus and to confine the attention, within such a group, to the discovery of the characters needed to differentiate species within the genus.

MEASUREMENT OF FLUCTUATIONS.

Almost all specific characters, however, may be defined in terms of the degree of their development in relation to the degree of development of some other particular characters. To reduce this fluctuating element to mathematical expression is the first necessity. In the spirifers the most conspicuous of these fluctuating characters are the several elements of form of the two valves-the length, width, thickness, cardinal area, curvature of surface, sinus and fold, size and number of plications, lines or pustules of surface, and so forth. All of these can be expressed mathematically by ratios of actual dimensions to some standard unit of measurement on the individual organism which increases coordinately with individual growth.

GOSSELET'S METHOD.

In measuring the characters of Spirifer verneuili Gosselet ${ }^{1}$ adopted the length of the brachial valve, measured from the beak to the front of the shell, as a standard. This dimension, expressed in millimeters, is adopted as the unit of measurement in the following studies and,

1 Gosselet, I., Étude sur les variations du Spirifer verneuili: Mém. Soc. géol. Nord, tome 4, pt. 1, 1894. 
whatever its actual dimension, is given the value 100 in determining the percentage ratio for other dimensions. It is represented by the symbol $\mathrm{L}$.

The greatest width of the shell, in millimeters, is represented by the symbol $W$. This width in terms of the unit of measurement is obtained by reducing the actual width in millimeters $(W)$ to a percentage value of the length of the brachial valve; this percentage value is represented by the symbol $\mathrm{R}^{1}$ or $\mathrm{w}$.

For instance, in a shell having a brachial valve length of 34 millimeters and a width between cardinal extremities of 75 millimeters: $\frac{W^{T}}{\mathrm{~L}}=\frac{75}{34}=2.21=\frac{221}{100}$; that is, the width $(\mathrm{W})$ is 221 per cent of the length, and $w=221$.

The height of the area of the pedicle valve, which is an important element in the morphology of spirifers, may be represented by the symbol $A$, and its percentage value in relation to the length of the shell by $R^{2}$ or a. If the height of the individual cited above be 5 millimeters, then: $\frac{\mathrm{A}}{\mathrm{L}}={ }_{34}^{5}=.146=\frac{14.6}{100}$; that is, the height (A) is 14.6 per cent of the length; and $\mathrm{a}=14.6$

The value of the thickness of the whole shell with reference to the unit of measurement may be obtained in the same way. Let the thickness be represented by $\mathrm{T}$ and its percentage value by $\mathrm{R}^{3}$ or $t$. Then, if the individual cited above has a total thickness of 31 millimeters: $\overline{\mathrm{L}}=\frac{31}{34}=.91=\frac{91}{100}$; that is, the thickness $(\mathrm{T})$ is 91 per cent of the length $(\mathrm{L})$; and $t=91$.

To express the expansion of the fold and sinus let the width in millimeters from side to side at the front margin be designated $F$ and the percentage value $R^{4}$ or $f$. If, in the shell cited above, $\mathrm{F}=23$ millimeters, then $: \frac{\mathrm{F}}{\mathrm{L}}=\frac{23}{34}=.67=\frac{67}{100}$; that is, the expansion (F) is 67 per cent of the length, or $\mathrm{f}=67$.

This method of expressing characters by ratios to a unit of measurement provides a set of numbers that have exact relation to each other and that show the form of the individual in terms which may be mathematically compared with those relating to any other individual expressed in a similar way irrespective of the actual size of the specimens. For the individual specimen cited above the elements are:

Mathematical expression of characters of a particular spirifer shell.

\begin{tabular}{|c|c|c|c|}
\hline $\begin{array}{l}\text { Sym- } \\
\text { bol. }\end{array}$ & Character. & Millimeters. & $\begin{array}{c}\text { Percentage } \\
\text { value. }\end{array}$ \\
\hline $\begin{array}{l}\mathbf{L} \\
\mathbf{W} \\
\mathbf{A} \\
\mathbf{T} \\
\mathbf{F}\end{array}$ & 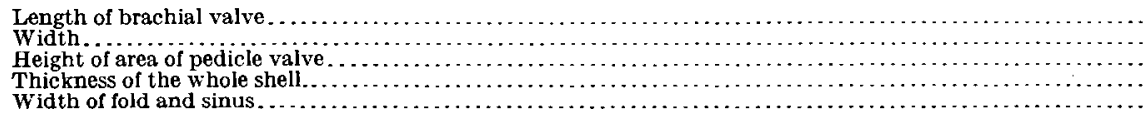 & $\begin{array}{r}34 \\
75 \\
5 \\
31 \\
23\end{array}$ & $\begin{array}{l}100 \\
221(w) \\
14.6(a) \\
91(t) \\
67(f)\end{array}$ \\
\hline
\end{tabular}

In Gosselet's classification of Spirifer verneuili six groups were recognized, based on the values of the ratio $w=100 \frac{W}{\mathrm{~L}}$. The extreme values observed fluctuate between 140 and 400 . The six groups are:

Gosselet's scheme of classification of Spirifer verneuili.

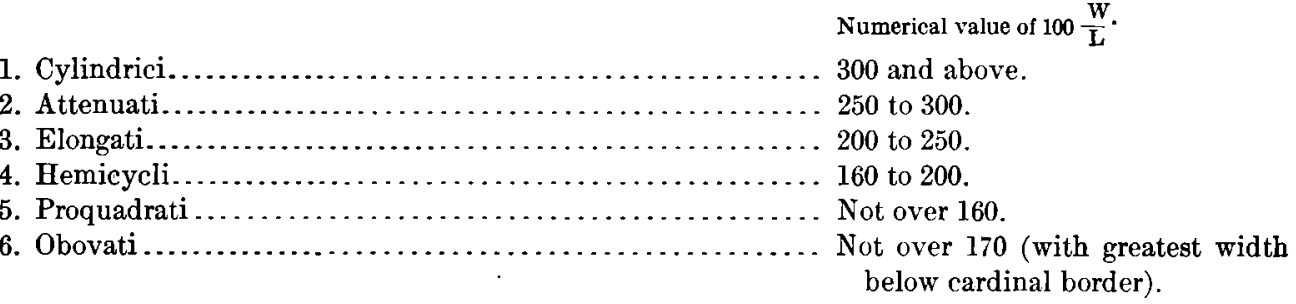


Gosselet's classes of form are very frequently represented among the spirifers of the American Paleozoic rocks, many specific groups including several of them within their range of fluctuation. For instance, each of the common New York Devonian species as classified by Hall ${ }^{1}$ has representatives in most of the first five of Gosselet's groups. As furnishing names for groups based on a particular range in flúctuation of one set of characters these are useful arbitrary divisions.

APPLICATION OF GOSSELET'S METHOD TO SPIRIFER MARCYI.

The species Spirifer marcyi I have found to express the same fluctuations in form so admirably described by Gosselet for the species Spirifer verneuili. Spirifer marcyi, however, has other variations which materially affect its external shape: (1) It shows variation in height of area and in classifying the species it is important to consider the areal height; (2) in some specimens some of its plications dichotomize with the growth of the shell, appearing to indicate a tendency to grow toward other species common in the next geologic system; (3) a rudimentary syrinx appears on some specimens, though this, with other characters that may be found later, may occur without signifying such departure from the general characteristics of the species as to call for a supposition that the evolutional genetic relationship has been broken. In view of these facts it has seemed to me appropriate to apply to species showing the several combinations of these fluctuating characters an indefinite series of arbitrary names (alpha, beta, gamma, delta, etc.) rather than one based upon any one of the many fluctuating characters of the species.

SPIRIFER MARCYI TYPICALIS, ALPHA, AND BETA.

To obtain the primary subdivisions of the group Spirifer marcyi I measured the original form to which the name was first applied and gave to it the name Spirifer marcyi typicalis (Pl. IV, figs. 1 and 2). Next I took the varietal forms associated with typicalis by the describer of the species in fully illustrating his conception of its form, and to two of these showing decided modifications I assigned the names Spirifer marcyi alpha and S. marcyi beta. Later, as new forms of the same genus were discovered in tracing it upward from the Hamilton, I added gamma, delta, and so on.

The original description and illustrations of Spirifer marcyi were published ${ }^{2}$ in 1857 , the geologic horizon and locality of the type being "shales of the Hamilton group, Covington, Genesee County, N. Y." In the final report (1867) the specimen figured in the first definition of the species is apparently refigured. ${ }^{3}$ For critical purposes this figured form is taken as the type of the species to which the name Spirifer marcyi typicalis is here applied. The length $(\mathrm{L})$ of the brachial valve of this specimen is 35 millimeters. The specimen is somewhat unsymmetrical; the half width on the left side is 34 millimeters, and on the right side is 30 millimeters as drawn, giving for the shell the total width (W) of 64 millimeters. The areal height of the pedicle valve (A) is 12 millimeters; the width of the deltidial opening (D) is 12 millimeters. If each of these dimensions be expressed in percentage ratios to the length of the brachial valve, the following ratio values (indicated by the corresponding letters) are obtained: $l=100 ; w=183 ; a=34$; and $\mathrm{d}=34$.

Figure 17 of the same plate shows a brachial valve, the dimensions of which are $\mathrm{L}=33.8$ and $W=75$ millimeters, and the ratio values $l=100$ and $w=222$.

Figure 15, a pedicle valve, gives, in millimeters, $\mathrm{L}$ (estimated) $28 ; \mathrm{W}=83.5$, and $\mathrm{A}$ (estimated) $=8$. The ratio values are $\mathrm{l}=100, \mathrm{w}=298$, and $\mathrm{a}=28+$.

Figure 19 appears to present similar dimensions to figure 15.

Figures 10, 11, and 12, which are different views of the same specimen, present the following dimensions (in millimeters): $\mathrm{L}=24 ; \mathrm{W}$ (estimated) $=48$ (actually 45 ); $\mathrm{A}=10 ; \mathrm{D}=7.5$; these correspond to $\mathrm{l}=100 ; \mathrm{w}$ (estimated) $=224$ (actually 211 ); $\mathrm{a}=47 ; \mathrm{d}=35$.

\footnotetext{
1 Paleontology: Geol. Survey New York, vol. 4, 1867; Spirifer mucronata, Pl. XXIV; Spirifer medialis, Pl. XXXVIII; Spirifer mesistrialis, PI. XL.

2 Tenth Ann. Rept. Regents New York, 1857, pp. 158 and 159

3 Paleontology: Geol. Survey New York, vol. 4, 1867, Pl. XXXVII, fig. 13.
} 
In these dimensions may be recognized three forms following:

Primary subdivisions of Spirifer marcyi.

\begin{tabular}{|c|c|c|c|c|}
\hline & 1 & $\mathbf{w}$ & $a$ & d \\
\hline $\begin{array}{l}\text { Spirifer marcyi typicalis (fig. 13)..... } \\
\text { Spirifer marcyi alpha (figs. 15, 17,19). } \\
\text { Spirifer marcyi beta (figs. 10,11, 12) } a_{\text {. }}\end{array}$ & $\begin{array}{l}100 \\
100 \\
100\end{array}$ & $\begin{array}{l}200 \text { or less.... } \\
200 \text { or more.... } \\
200 \text { or more.... }\end{array}$ & $\begin{array}{l}35 \text { or less...... } \\
\text { Less than } 35 . \\
\text { More than } 35 .\end{array}$ & 35 or less. \\
\hline
\end{tabular}

a Pl. IV, figs. 3, 4, and 5; and Pl. V, fig. 5, of this paper.

This form, called Spirifer marcyi in the Hamilton formation, belongs to a series of forms which pass, in respect of some of their characters, directly into the species Spirifer granuliferus $\mathrm{Hall}=$ granulosus, as was observed by Hall in the original description of the species. In the value of characters here expressed the species $S$. granulosus fluctuates beyond $S$. marcyi typicalis in the opposite direction from varieties alpha and beta. Spirifer granulosus rarely reaches 175 for value of $w$ and rarely over 25 for value of a. Other characters of a positive nature distinguish the two species. It is to be further noted that Spirifer granulosus has never been seen among the recurrent forms in the Upper Devonian of New York. Spirifer granulosus and S. marcyi formed in the Hamilton a continuous series of fluctuating forms, which thereafter became specifically distinct; the low area; overarching of the beak; the increase in growth over the middle of the shell, both forward and sidewise, producing a swollen central part and a wide fold and sinus; and the larger and fewer plications are characteristics of the Middle Devenian evolution of the gens expressed in the Hamilton by the typical Spirifer granulosus. The increased height of area and its less arched, nearly straight, surface; and the excessive growth toward the cardinal extremities with less growth in center of shell, giving straighter sides to the shell and less lateral expansion of the center part of the shell, and thus increasing the number of ribs and narrowing the width of the fold and sinus-these are peculiarities of the Upper Devonian evolution of the race already expressed in the Hamilton by the gens Spirifer marcyi. The nonpustulose gens of Spirifer audaculus-macronatus-angustus passed through this stage of evolution during Hamilton time, and probably ended its existence with the close of Middle Devonian.

It is significant (tying together the granulosus with the marcyi sections of the race) to note the discovery of the rudimentary syrinx in a form of the variety Spirifer granulosus clintoni of the Hamilton. (See Pl. V, fig. 4.) In the recurrent S. marcyi of the Upper Devonian this character is frequently seen

SPIRIFER MARCYI GAMMA.

In the Tropidoleptus recurrent zone No. 2 a variety not seen in the Hamilton occurs. To this is given the varietal name gamma. (See Pl. IV, figs. 7 and 8, and Pl. V, fig. 3.) The specimen selected as type for this variety is a mold of the interior showing both valves and having the following dimensions (in millimeters): $\mathrm{L}=26 ; \mathrm{W}=46$ (twice the width (23) of the more perfect side; the actual width shown is 37 ); $\mathrm{A}=18 ; \mathrm{D}=7.3 ; \mathrm{F}=$ (estimated) 13 . These dimensions reduced to scale are $l=100 ; w=177 ; a=69 ; d=24 ; f=50$. They may be generalized as follows: $\mathrm{l}=100 ; \mathrm{w}=175$ to 190 (narrower than in var. typicalis); $\mathrm{a}=+50$ (high and nearly flat and erect); $d=25$ to 30 (narrow and high); $f=50$ or less. The fold in this specimen is probably artificially flattened, as in general the fold of this form is narrower. Several specimens have been seen showing these general proportions.

The dimensions being of the interior may not accurately express outside measurements, but the proportions are probably approximately the same.

SPIRIFER MARCYI DELTA.

The type specimen representing Spirifer marcyi delta (see Pl. IV, fig. 9; Pl. V, fig. 13) comes from the faunule El. $6 \mathrm{~L}, 1 q$. This is in the recurrent zone No. 2, southwest of Southport, in the Elmira quadrangle. 
The type specimen is a not altogether perfect mold of the interior, and the following measurements (in millimeters) are somewhat estimated: $\mathrm{L}=19 ; \mathrm{W}=40 ; \mathrm{A}=10 ; \mathrm{F}=10$. Reduced to scale, these become: $l=100 ; \mathrm{w}=210 ; \mathrm{a}=52 \frac{1}{2} ; \mathrm{f}=52 \frac{1}{2}$. Another specimen gives the following dimensions (in millimeters): $\mathrm{L}=26 ; \mathrm{W}=61 ; \mathrm{A}=18$; these correspond to $\mathrm{l}=100$; $\mathrm{w}=234 ; \mathrm{a}=69$. From these measurements the following values may be assigned to the varjety delta: $\mathrm{l}=100 ; \mathrm{w}=200$ to $250 ; \mathrm{a}=50$ to 75 .

In this form two new morphologic characters are expressed: (1) The plications near the middle of the shell, on both sides of the fold and sinus, show furrows in the upper surface tending to dichotomize the plications at the front; and (2) the sides of the sinus bear two shallow grooves, producing the appearance of two distinct plications of the same size as those outside the sinus. These are inconspicuous above the middle, but for the front part of the shell they are well defined. The surface pustules are fine and closely arranged and not so elongate or loosely distributed over the surface as in variety typicalis.

The additional plications on the slopes of the sinus resemble those described ${ }^{1}$ as characterizing some specimens of Spirifer parryana of the Lower Devonian. S. parryana is a closely related species and is near this variety in form. Its surface sculpture is, however, made up of fine longitudinal lines instead of consisting of distinct pustules irregularly distributed over the surface, as Spirifer marcyi delta.

SPIRIFER MARCYI EPSILON.

The specimens I have selected to illustrate the variety epsiton are from the northern slope of Ashland Hill, a few miles southeast of Elmira, at an altitude of about 950 feet, well up in the Chemung formation. (See Pl. V, figs. 9 and 12.) It is a form much extended laterally, with high area; the greatly elongated pustules are arranged in parallel lines, giving the appearance of pustulated lines, and the plications near the cardinal extremities on the pedicle valve are in some specimens increased by intercalation. The dimensions of this specimen (in millimeters) are: $\mathrm{L}=$ (estimated) $13, \mathrm{~W}=$ (estimated) $50, \mathrm{~A}=$ (estimated) $10, \mathrm{~F}=9, \mathrm{D}=6$. Reduced to scale these dimensions give $\mathrm{l}=100 ; \mathrm{w}=384 ; \mathrm{a}=77 ; \mathrm{f}=69 ; \mathrm{d}=46$.

The area is thus high and erect and the width of both area and delthyrium high, and the variety may be described as a much-mucronated form of variety beta. The form shows extreme production laterally; the elongate pustules run into distinct lines in the sinus; a faint indication of an auxiliary plication is seen on the slopes of the sinus; and a distinct intercalation of a plication betwcen two regular ones, near the cardinal extremity of one of the wings, is evident. These pustules and plications are new characters.

SPIRIFER MARCYI ZETA.

Several specimens, here called zeta (PI. V, fig. 8), show an attenuation of the cardinal angles still greater than that of var. epsilon but do not possess the special surface sculpture of the latter.

The specimen selected as type of this variety is from fauna of Wv. 7B, $1 f$. In form, zeta is very much like epsilon, but its pustules are fine, numerous, and not arranged in parallel lines, and the bifurcation of its plications or their addition by implantation in process of growth is not evident in all specimens, though it appears on the type specimen near the extremity of the attenuated shell.

The actual dimensions of this type specimen of variety zeta are (in millimeters): $\mathrm{L}=6$; $\mathrm{W}=27$ to $32 ; \mathrm{A}=5+; \mathrm{F}=3+$; these correspond to $\mathrm{l}=100 ; \mathrm{w}=450$ to 530 (estimated from one side) $; a=83$ (estimated from one side) $f=50$.

This in general terms is a laterally much-produced attenuate form with broad fold and sinus, fine pustules, and occasional implantation of extra plications between the cardinal margin and the lateral extremity of the shell. It is in form the var. epsilon without the new characters of that variety. 
THE RUDIMENTARY SYRINX.

Occurrence.-On several specimens of the Spirifer marcyi gens, not confined to those of any particular variety as expressed in terms of form, a rudimentary syrinx has been observed. (See Pl. IV, figs. 8 and 10, and $\mathrm{Pl}$. V, figs. 4 and 7.) This new character consists of an infolding of the outer wall of the transverse plate near the apex of the umbonal cavity into two more or less twisted, narrow, short plates. In order to designate the appesarance of this new character irrespective of the varietal form of the specimens expressing it, I have used the varietal name sigma.

Spirifer granulosus.-The earliest representative of the rudimentary syrinx I have seen is in specimens of Spirifer granulosus clintoni Hall (PI. V, fig. 4), collected by C. S. Prosser from the Hamilton fauna at Pleasant Brook, Upperville, near Smyrna, and listed by him ${ }^{1}$ as "Spirifer granulosus (Con.) Hall and Clarke." 2

The specimen, which is somewhat crushed, is a mold of the interior. Its dimensions (in millimeters) are: $\mathrm{L}=21 ; \mathrm{W}=40$ (estimated; actually, 37); $\mathrm{A}=$ (estimated) $6 ; \mathrm{D}=$ (estimated) $6 ; \mathrm{F}=$ not over 11 (actually 13 ); these correspond to $\mathrm{l}=100 ; \mathrm{w}=190 ; \mathrm{a}=28 \frac{1}{2} ; \mathrm{d}=28 \frac{1}{2}$; $\mathrm{f}=50$.

The form is thus seen to be, in terms of the fluctuating characters, below variety typicalis of the Spirifer marcyi group in the values of a and d and about equal to it in the value of $w$.

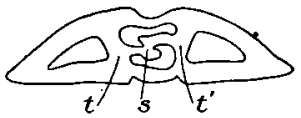

FIG. 15.

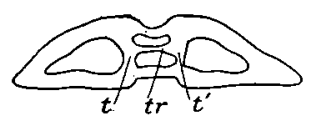

FIG. 16.

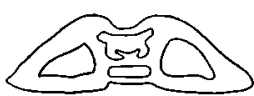

Fig. 17.

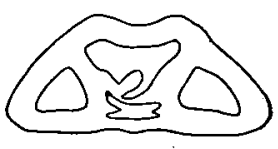

Fig. 18.

FIG URE 15 .-Cross section of beak of Spirifer granulosus sigma, showing rudimentary syrinx. $t, \ell^{\prime}$, Teeth plates; $s$, transverse plate connecting teeth plates.

Figure 16.-Cross section of beak of normal spirifer granulosus. $t r$, Transverse septum connecting teeth plates, $t, t^{\prime}$, at apex of interior of pedicle valve.

FIGURE 17.-Cross section of beak of Spirifer marcyi sigma, showing rudimentary syrinx.

FIGURE 18.-Cross section of beak of Syringothyris sp., showing complete syrinx.

It has the median groove in the fold and the faintly marked plications on sides of the sinus defined as characterizing some specimens of Spirifer granulosus.

The rudimentary syrinx is represented by an irregular twisting of the transverse plates at the apex of the beak represented in figure 15. The form shown may be called Spirifer granulosus sigma.

Other specimens of similar external appearance appearing in the same faunule do not exhibit this varietal character, but are like the normal Spirifer granulosus, as shown in figure 16 .

Spirifer marcyi sigma.-In some of the recurrent representatives of Spirifer marcyi in the Upper Devonian the twisting representing the rudimentary syrinx is seen; but more generally the character is expressed as in Plate IV, figures 4 and 6.

The specimen chosen for illustrating this character in Spirifer marcyi (Pl. IV, fig. 10) is from station Dr. 8I, 1c. It is the mold of the interior of a pedicle valve whose dimensions (in millimeters) are as follows, viz: $\mathrm{L}$ (estimated), $21 ; \mathrm{W}$ (one-half $=27$ ), $54 ; \mathrm{A}$ (estimated) $=13$; D (estimated) $=9$; these correspond to $\mathrm{l}=100 ; \mathrm{u}=257 ; \mathrm{a}=62 ; \mathrm{d}=43$.

In form it comes, therefore, into variety beta. The outer edge of the transverse plate between it and the pseudodeltidium is not preserved; if it be assumed to be flat, figure 17 expresses the cross section of the shell near the apex of the beak.

In the molds this character is expressed by two ridges starting near the apex of the cavity and running downward toward the center of the shell with the outer faces convex and the inner surfaces concave; it thus forms, on the outer face of the transverse plate, a scooplike plate,

1 Prosser, C. S., The classification and distribution of the Hamilton and Chemung series of central and eastern New York: Fifteenth Ann. Rept. State Geologist, New York, 1895, p. 119.

2 Paleontology: Geol. Survey New York, vol. 4, 1867, p. 223. 
the edges of which curve inward and tend to form a tube, though in the specimen the edges are wide apart.

To this variation I give the varietal name Spirifer marcyi sigma and will apply the same name to other forms of the gens Spirifer marcyi without consideration of the other varietal name applied on basis of external form.

Syringothyris.-In order to show the relationship of this rudimentary structure to that of the syrinx of the typical Syringothyris (see PI. V, figs. 6 and 7), I have prepared a diagram (fig. 18) showing the corresponding part of the shell of a specimen from Smethport, Pa. (locality $1471 \mathrm{B6}$ ), collected by Kindle. The specimen is a stone mold of the interior, showing the characteristic syrinx and teeth plate as cavities, which have only to be reversed to represent the solid parts of the shell as it was before solution from the matrix.

Interpretation of the syrinx.-In the specimen figured (Pl. V, fig. 7) the relation between the slit of the tube and the ridges to which the posterior part of the adductor scar is attached is evident. It confirms the interpretation given to this "canal system," as the syrinx is called by King," and as illustrated by the figures drawn by Davidson-that it was for muscular attachment.

The slit in the specimen from Smethport directly connects with the part of the muscular scar marked $e$ on figure 31 of King's paper and seen distinctly, though not marked by letter, in the upper part of the delthyrial cavity of his figure 32 . King concludes that the "canal itself has served as a muscular fulcrum for the dorsal pedicle muscles, which ordinarily have one extremity implanted on the intercrural plate of the dorsal valve and the other attached to the pedicle." 2

The facts here brought to light seem to suggest that the muscles which were attached to this twisted plate in the apex of the ventral (pedicle) valve were attached by their other end in front of the teeth fulcrum and hence were adductors in action. The direction of the axis of the syringal tube is slightly away from the plane of the area toward the center of the brachial valve when the two valves are closed. This may account for the development of the grooves, kept free by formation of the syringal plate, in shells in which the erect position of the area throws the posterior part of the adductor scar far out toward the extremity of the beak. It is observed in the specimen from Smethport (Pl. V, fig. 6) that the plane of the area is almost parallel with the plane on which the muscular scar of the diductors are attached, so that these two sets of muscles must have acted nearly at right angles to each other.

In all specimens in which the rudimentary expression of the syringal plates has been observed the explanation above made of them appears to be sufficient to account for the structure. The development of the curved plates, called when complete a syrinx, is functionally the device by which free space is provided for the play of these posterior bundles of the adductor muscles, as the straightening up of the plane of the area of the pedicle valve in relation to the brachial valve throws them up against the delthyrial plate. So long as the pedicle beak arched over the brachial valve the open umbonal cavity of the shell gave free play to these muscles, and as, with the growth of the apex of the beak, this space became filled in with shell deposit these adductors continued to have free play outside (that is, anterior to) the transverse plate.

DISTRIBUTION OF VARIETAL FORMS OF SPIRIFER MARCYI.

Examination of the fluctuating characters exhibited by the Spirifer marcyi race as it passes from Middle Devonian through the recurrent zones in Upper Devonian has led to the discrimination of eight varieties-typicalis, alpha, beta, gamma, delta, epsilon, zeta, and sigma.

In the following table I have arranged the specimens from the several recurrent Upper Devonian zones so as to exhibit the particular varietal form assumed in each locality and zone.

1 King, W., Monograph of Spirifer cuspidatus (Syringothyris cuspidata) Martin: Annals and Mag. Nat. Hist., 4th ser., vol. 2, 1868, pp. 20, 21 and Pl. III, figs. 31 and 32 .

2 Op. cit., p. 22. 
Geographic and geologic distribution of the several varietal forms of the gens Spirifer marcyi in the Upper Devonian.

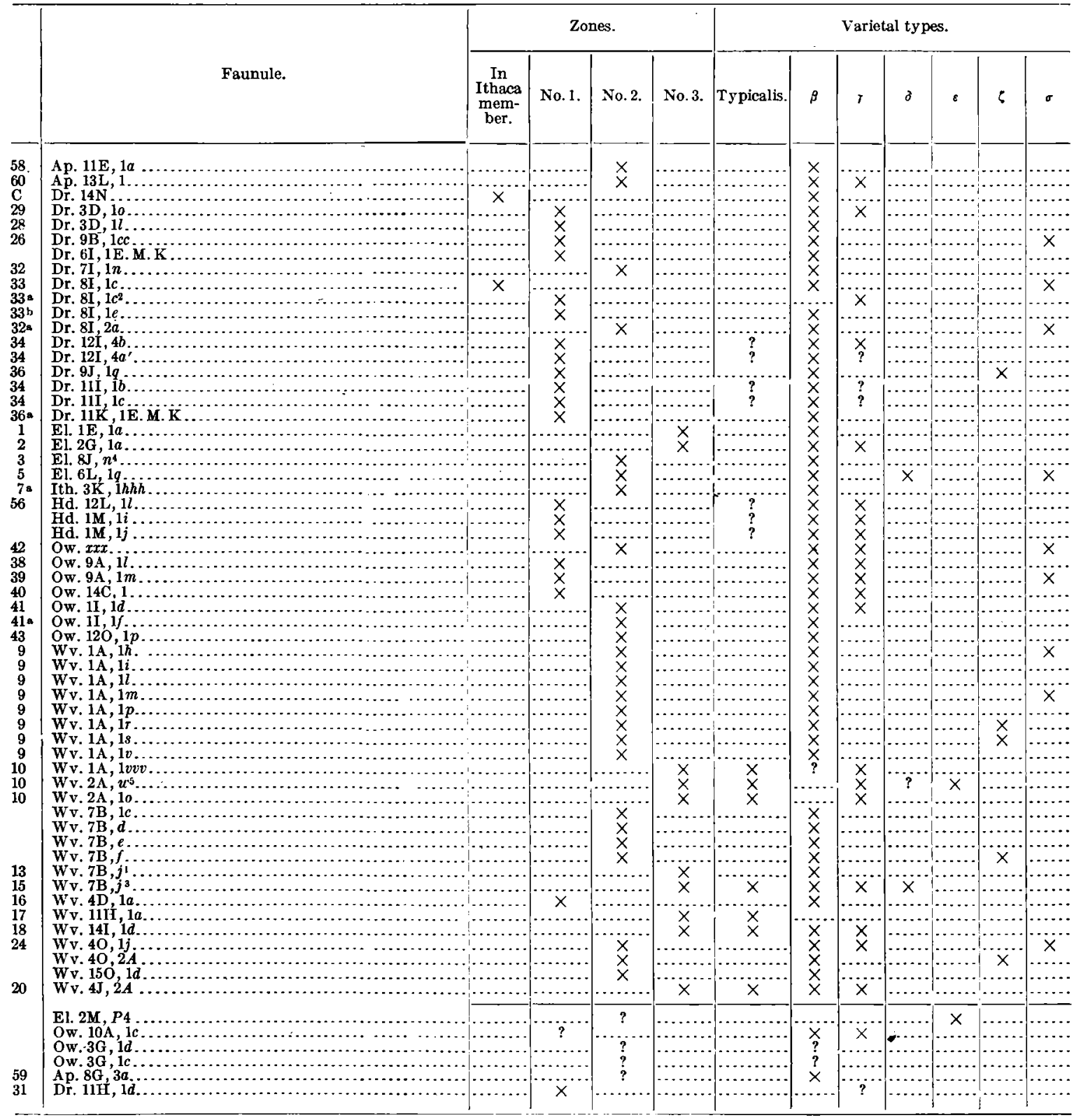

The numbers preceding the faunal symbol at the extreme left of the table correspond to the numbers used in the table of faunules of the recurrent Tropidoleptus zones on page 10. The same number is given several faunules because the recurrent zone of some of the sections is not restricted to a single stratum and its faunule but is found in several strata following one another, each carrying one or more of the typical recurrent species. Where no number precedes the faunal symbol the particular faunule was not ascribed to any one of the definitely established zones, but is from an isolated outcrop, its zonal position being determined by its fossils.

For fifty-seven of these local faunules the horizons are positively determined; for five others the exact horizon is not determined; and for the last in the list the characters of the specimen are doubtfully determined. 
Of the fifty-seven faunules whose horizons are determined, two are from the recurrent zone in the Ithaca member, nineteen from the Tropidoleptus zone No. 1, twenty-six from the zone No. 2, and ten from the zone No. 3.

The variety alpha has been detected in none of the recurrent zones. The variety beta has been seen in fifty-two (doubtful in fifty-third) of the fifty-seven faunules, being missing only in a few faunules from the zone No. 3.

The variety gamma has been seen in twenty faunules (doubtful in three others), of which nine are in the Tropidoleptus zone No. 1, four in the zone No. 2, and seven in the zone No. 3. This variety, gamma, it will be remembered, is the form with high area and cardinal extension less than 200 per cent of the brachial length. It is a form not recognized among the Hamilton representatives of the species.

Variety delta is typically represented in two of the fifty-seven faunules and doubtfully in a third. One positive occurrence is in the Tropidoleptus zone No. 2; the other positive and the one doubtful occurrence are both in the zone No. 3. This variety does not appear until the opening of the Chemung epoch.

The variety epsilon is typically from a faunule on the side of Ashland Hill south of Elmira (El. 2M, P4) at a horizon which is clearly in the Chemung; but on account of the peculiar combination of species in the faunule and the absence of Spirifer disjunctus (characteristic of the Chemung) from all faunules of the section both below and above, its exact place in the standard section is doubtful. The only other specimen of variety epsilon came from one of the outcrops of zone No. 3 (Wv. $2 \mathrm{~A}, W 5$ ), which is stratigraphically equivalent to the recurrent zone No. 10 of the list on page 10. The Ashland Hill specimen is undoubtedly as high as zone No. 2 but it may be of later stage.

Variety zeta is represented in five faunules, one of which is from the Tropidoleptus zone No. 1 , and the other four are from the zone No. 2. This variety is very much like epsilon in form; but in epsilon the elongation of the pustules into nearly parallel lines and the implanting of new plications during the growth of the shell is indication of progress in evolution beyond the stage reached by zeta. Neither of these forms is represented in the Hamilton formation of New York. In their high area and transverse elongation they resemble the species called Spirifer angustus by Hall, ${ }^{1}$ but differ from that species by their pustulose surface.

I have checked as variety typicalis several specimens from the Upper Devonian which, in the degree of fluctuation of the several characters here noted, fall characteristically within that group in the Hamilton; that is, their transverse extension (w) is moderate, being not over two hundred; their height of area (a) is also moderate, not over thirty-five; and their plications are approximately twenty on each side. Their pustules, however, are generally much finer and more closely spread over the surface than in specimens of the variety typicalis from the Hamilton.

A few forms from the earlier recurrent zones (No. 1 and No. 2) approach these characters but differ in having the area higher and the transverse extension less than in typicalis; by these characters they approach the variety gamma, and I have indicated them by a question mark.

In the variety typicalis column are seven positive and seven doubtful checks, as above defined. All seven of the doubtful occurrences are in faunules of the zone No. 1, and all of those positively idertified are from the zone No. 3. The variety gamma is also more numerous in these two zones. When it is remembered that the question is one of fluctuation, and that the samples are from successive zones and express successive stages in the history of the race, the significance of these lists becomes apparent.

STAGES IN EVOLUTION OF THE SPIRIFER MARCYI GENS.

Variety beta expresses the mean fluctuation of these several characters for the Upper Devonian stage of evolution. Variety gamma expresses the extreme fluctuation in the direction of short cardinal extension and high area. Variety delta expresses an extension of this general 
form gamma in respect of pustule and plication; the pustules are decidedly elongate, the sides of the sinus and the fold show the rudimentary plications seen in some specimens of Spirifer granulosus and other species, and ridges occur on top of the plications, tending to dichotomize them near the front; this variation is not assumed till the stage of the Tropidoleptus zone No. 2. Variety typicalis expresses the tendency shown in gamma carried farther from the mean (var. beta), in the direction of both shortening the transverse extension and lowering the relative height of the area. It is this extreme in fluctuation which was selected by the author of the species for the type figure of the species Spirifer marcyi of the Hamilton. In the Hamilton the lowest area was reached by the transversely elongate forms here called variety alpha, a variety which does not reappear in the Upper Devonian faunas. The forms with low area and short hinge extension are placed in the species Spirifer granulosus by the definition of Hall. They fail to reappear in the recurrent Upper Devonian faunules.

In the other direction from the mean represented by variety beta, the first stage of fluctuation is seen in variety zeta, in which the transverse hinge extension is excessive, but in which the high area is retained. This variety appears chiefly in the Tropidoleptus zone No. 2, a single specimen appearing in the stage zone No. 1. It is followed by the variety epsilon, in which the tendency is to increase the plications with growth and to elongate the pustules into paralle lines.

\section{GENUS DELTHYRIS.}

\section{RANGE OF SPECIFIC CHARACTERS.}

The genus Delthyris, as shown by its early confusion with Spirifer pennatus posterus, does not differ greatly in external form from the common Spirifer of the Ithaca shale member of the Portage formation. A thorough search of the collections demonstrates, however, that the distinctive mark of the genus Delthyris (the median septum of the pedicle valve) does not appear in any specimens of the fauna of the Ithaca member, not even in the zone in which Rhipidomella and Tropidoleptus are found at that lower stage. It is not until the second incursion (the stage introducing the recurrent fauna of the zone No. 1) that the septum appears. I have examined a great number of specimens (every one in the collections), and have failed to discover a single one, in any faunules from below the Enfield shale member of the Portage formation, which shows anything more than a slight, linear elevation on the interior of the pedicle valve where the septum appears in Delthyris. The earliest appearance of a distinct septum is in some specimens from the lower part of the Harford Mills section (Hd. 12G, $1 c$ and $1 d$ ), at an altitude of about 1,200 feet, collected by Mr. Reinecke. The specimens are associated with Rhipidomella and occur 250 feet below the Tropidoleptus zone No. 1 of this section, in which Tropidoleptus, Rhipidomella, and Delthyris appear; and it is not until the highest part of that zone is reached, at 1,500 feet elevation (300 feet above this first incursion), that Spirifer marcyi is found in the same faunule with it.

The remarkably long range of the zone No. 1 fauna in the eastern side of the area is associated with a remarkable thickening of the portion of the Enfield member through which the general brachiopod type of faunules ranges. In the western part of the area (west of Ithaca) the Enfield member shows scarcely a trace of brachiopods for nearly 600 feet above the top of the Ithaca member. In the Dryden, Owego, Waverly, and Ithaca quadrangles, the recurrent zone No. 1 is restricted to not over 200 feet of strata; and generally the fossiliferous zone is much narrower. In that zone, however, Spirifer pennatus posterus is replaced by Delthyris mesicostalis whenever it appears, thus furnishing a reliable guide in the field for distinguishing the higher recurrent zone No. 1 from the Ithaca member below, in which Spirifer pennatus posterus is a characteristic and often an abundant species.

Above the first appearance of Delthyris in the section, throughout the Cayuta member and upward into the Wellsburg member of the Chemung, all the spiriferoid species at all resembling the few-plicated Delthyris mesicostalis, or the wide and mucronately extended Spirifer pennatus with numerous plications, have the delthyroid septum. The external appearance of Delthyris $67437^{\circ}-$ No. $79-13 \longrightarrow 5$ 
mesicostalis in its smaller, less developed form is very similar to the external appearance of Spirifer pennatus posterus, which is very abundant in the early stages of the Enfield member in the Harford quadrangle. In specimens of the pedicle valve showing the mold of the interior the true Delthyris shows a distinct septum.

The specimens referred to Delthyris are distributed as follows by quadrangles:

Occurrence of Delthyris.

\begin{tabular}{|c|c|c|c|}
\hline Quadrangle. & \multirow{2}{*}{$\begin{array}{c}\text { Faunules } \\
\text { contain- } \\
\text { ing Del- } \\
\text { thyris. }\end{array}$} & \multicolumn{2}{|c|}{$\begin{array}{l}\text { Faunulescontaining } \\
\text { Delthyris and the } \\
\text { diagnostic gen- } \\
\text { era. }\end{array}$} \\
\hline & & Number. & Per cent. \\
\hline \multirow[t]{2}{*}{ 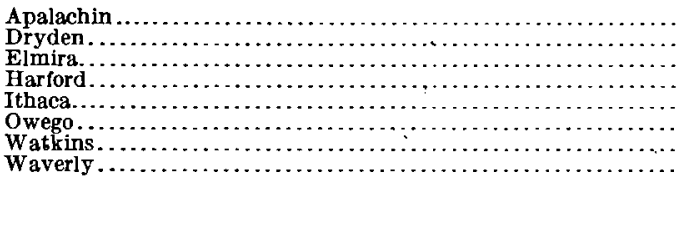 } & $\begin{array}{r}10 \\
38 \\
37 \\
49 \\
5 \\
25 \\
5 \\
133\end{array}$ & $\begin{array}{r}5 \\
23 \\
4 \\
27 \\
1 \\
8 \\
\hdashline 34\end{array}$ & $\begin{array}{l}50 \\
60 \\
10 \\
55 \\
20 \\
32 \\
25+\end{array}$ \\
\hline & 302 & $\begin{array}{c}04 \\
102\end{array}$ & $\frac{\omega t}{33+}$ \\
\hline
\end{tabular}

In the Ithaca and Watkins quadrangles only a few faunules contain Delthyris and only one of these few is in a recurrent zone; this is because the surface exposures in these quadrangles are of rocks below the zone No. 1, that is, of the Enfield member of the Portage formation. In the Dryden and Harford quadrangles, on the other hand, more than the average percentage (60 and 55) of the occurrences are in the recurrent zones; this is because there are many outcrops of the zone No. 1 in these quadrangles and not many of the Chemung rocks. In the Apalachin, Elmira, Owego, and Waverly quadrangles 50 per cent or more of the occurrences of Delthyris are outside of the recurrent zones; this is because the rocks exposed in these quadrangles are chiefly Chemung, and Delthyris is plentiful in the Chemung outside the recurrent zones.

Above the Hamilton the genus Delthyris does not distinctly appear in the faunas till the Tropidoleptus zone No. 1 is reached; of the 26 sample faunules selected for special study from the zone No. 1 all but three contain Delthyris, and these three probably hold the genus, though no specimens were actually obtained. Above the zone No. 1 Delthyris is found abundantly in the rocks of the Chemung. Many of the upper Portage faunules containing Delthyris may belong to the fauna found in the particular, restricted, Tropidoleptus zone No. 1; but they are at present ruled out as not strictly representing the recurrence because of their lack of the three diagnostic forms above specified.

\section{PROBLEM OF RECURRENCE.}

The disappearance of the earlier forms (like Spirifer pennatus posterus) contained in the Ithaca member of the Portage may be explained as resulting either (1) from their extinction in the area, or (2) from their modification on passing upward in to the new type Delthyris mesicostalis.

This involves the question of their recurrence-whether Delthyris persisted in the area in modified form or whether it retreated and came back later, unmodified, with the other Tropidoleptus fauna. The data are not yet sufficient to show positively which of these has taken place. However, in my early study of the problem I had strong conviction that the later forms (called properly Delthyris mesicostalis) were directly evolved from the earlier forms, now known as Spirifer pennatus posterus.

The difficulties in reaching a satisfactory conclusion are as much rational as observational.

In the Hamilton, below, Spirifer pennatus and Delthyris consobrinus are thoroughly differentiated. In the recurrent zone No. 1 some of the specimens of Delthyris mesicostalis show no visible morphologic characters by which they may be distinguished from their forerunner, D. consobrinus. So great is the resemblance of the two species, emphasized as it is by the 
concurrent association of other species of Hamiltonian type, that the natural interpretation is that Delthyris consobrinus persisted in some central region and at this later stage drifted back into the area, as Detthyris mesicostalis, holding its characters unchanged with the passage of time from Hamilton nearly to the close of the Portage epoch.

On the other hand, examination of the series from the base of the Ithaca upward gives an undoubted sequence of Spirifer pennatus posterus, followed by Delthyris mesicostalis in the early stages of the recurrent zone No. 1, in the middle and upper part of the Enfield member. These latter forms might be easily imagined to be simply members of a series of modified descendants, the differential characters of which have become more marked on passing upward into the Cayuta member of the Chemung.

Observationally, the series of successive forms is quite correct, but the gradual-modification explanation is based on a theory of evolution different from that of the other explanation. By the one theory, if the forms Delthyris mesicostalis and associated Spirifer pennatus of the zone No. 1 are descendants of the same stock from which Delthyris consobrinus and Spirifer pennatus of the Hamilton arose, then for a very long period of time these two races continued to reproduce without appreciable modification in some region outside of the area discussed, and finally recurred (or drifted back into it) practically unchanged in form. By the other theory the two races remained on the ground and evolved by gradual modification into the later forms. The interpretation of the facts in their relation to recurrence turns upon the possibility of an organism continuing for very long periods of time to reproduce its ancestral characters without appreciable modification.

If it be held that they can so reproduce and if, nevertheless, a succession of forms of the same race expressing slight accumulative modification is observed, then (1) either the hypothesis of nonmodification does not apply to the race under consideration, or (2) some reason exists for the lack of modification on the one hand and the presence of it on the other.

The problem calls for deeper study, which perhaps may lead to the discovery of some interesting laws, now only dimly perceptible, which may furnish an explanation of the sequence of the faunas.

Delthyris does not add to the direct evidence in favor of the recurrence of the Tropidoleptus fauna.

\section{GENUS CAMAROTECHIA.}

SPECIFIC DISCRIMINATION.

In the faunal list I have divided the representatives of the genus Camarotæchia into four groups, calling them Camarotochia congregata, C. eximia-stephani, C. sappho, and C. contracta. Selected specimens may be taken which fairly well represent the specific types indicated by the names, but the fluctuating characters are so constantly expressed, as the genus passes upward from the Hamilton, that it is difficult to distinguish between characters which are of evolutional significance and normal fluctuating variations. I have not subjected the characters to the minute measurement and statistical tabulation necessary to demonstrate their historic relations. A few remarks, however, may be made regarding the broader characteristics expressed as they mount through the Upper Devonian beds.

The genus is not confined to the Tropidoleptus recurrent zones.

The group called by me Camarotochia eximia-stephani, because the majority of its specimens present the characters of these two species as defined, is less common in the Hamilton than in the Upper Devonian. The young or small specimens, all of which are very similar, are common all through the Ithaca member, and a few of them appear higher up. The adult form, which has the beaks rather narrow and the sides straight (typically called Camarotochia stephani), is common in the Ithaca and scarce above. The broader forms reach the form called C. eximia in the recurrent zone in the Ithaca and in the zone No. 1.

The gibbous type called C. sappho is rarely seen in the Ithaca but is conspicuous in the zone No. 1 of the Portage and in the higher faunas of the Chemung. 
The form with few plications, smaller in size than C. sappho, with which it is associated, is C. contracta. This species is rarely seen in the Portage but is conspicuous in the Chemung.

In the Tropidoleptus zone No. 2 a conspicuous form resembles $C$. congregata as it appears in the Hamilton but is associated with $C$. eximia, C. sappho, and C. contracta forms.

\section{PROBLEM OF RECURRENCE.}

Here again the facts may be explained in two ways. It may be supposed (1) that such forms as $C$. eximia-stephani have undergone evolutional modification as they have passed upward into the Chemung, or (2) that the differences at the higher horizons result from the incursion of species that have retained their ancestral character unchanged. No satisfactory conclusions on this subject can be reached with the present knowledge of this generic group. For the present it is sufficient to state that Camarotœchia can not be used to strengthen the hypothesis of recurrence for the chief reason that the genus occurs in the intermediate faunules as well as in the particular zones carrying the characteristic Hamilton types.

\section{GENUS CYPRICARDELLA.}

RANGE.

Although the genus Cypricardella is shown to occur numerously in the recurrent zones, its great rarity in typical samples of the Tropidoleptus zone No. 1 casts doubt on its direct origin from a Hamiltonian source. Its abundance in some of the Hamilton zones makes such an origin possible, but its presence in the fauna of the Ithaca member, outside the zones in which the Tropidoleptus has been actually detected, casts still further doubt upon its legitimacy as an element of the Tropidoleptus recurrent fauna. The reason for at first supposing that it was a constituent of the recurrent fauna was its discovery in the Tropidoleptus zone No. 2 in the first find containing Tropidoleptus and Rhipidomella. In these recurrent zones all three genera are represented by species showing no appreciable modification from the common Hamilton representatives. As the search was extended, Cypricardella was found to be not always associated with the other two and it was also seen in strata showing neither of the other more characteristic Hamilton species. This began to throw doubt on the first hypothesis, and as the statistics were finally put together it was seen that'few faunules of the Tropidoleptus zone No. 1 hold Cypricardella.

Close examination of the faunules disclosed 116 that contain Cypricardella. Not all of these belong to C. bellistriata, but the others are of closely allied species, evidently modified permanently from that stem. The finds are distributed as follows: Apalachin, 7; Dryden, 5; Cortland, 14; Elmira, 14; Harford, 30; Ithaca, 6; Owego, 6; Waverly, 34 .

Of these 116 faunules only 35 can be shown to belong to the zone in the Ithaca member and to zones Nos. 1, 2, and 3. The genus appears scattered all through the Upper Devonian beds, from the earliest traces of the Ithaca fauna in the Portage formation to high up in the Wellsburg member of the Chemung. It is particularly noticeable in the faunules of the eastern extension of the Ithaca member in the Harford and Cortland quadrangles, and in the general Cayuta fauna not restricted to the particular Tropidoleptus zones Nos. 2 and 3. All specimens seen associated with the other recurrent species present the surface characteristics of Cypricardella bellistriata, but many of them are small in size. It has been discovered in only two of the recurrent zones on the eastern side of the area-Harford Mills (Hd. 13G, 1rr) and Lisle (Hd. 2J, 1e). It is present in eight of the eleven samples of zone No. 3. NItogether there are rather strong reasons for believing that the species Cypricardella bellistriata came into the central New York area with the Hamiltonian magna fauna, but that its migratory movements were less rapid, it being both slower to arrive and adopt the new conditions and also slower to depart when the general fauna withdrew. The specific forms of the genus more intimately associated with the Upper Devonian faunas are not typical $C$. bellistriata and they may perhaps be considered as mutants adjusted to remain when the typical species of the recurrent zone withdrew or were extinguished by the prevaling conditions of the environment. 
The species Cypricardella bellistriata is a diagnostic and often an abundant constituent of the recurrent fauna in the Tropidoleptus zones Nos. 2 and 3.

SPECIFIC CHARACTERS OF CYPRICARDELLA BELLISTRIATA.

HAMILTON FORMS.

Cypricardella bellistriata was first described and figured by Conrad, ${ }^{1}$ who in 1842 defined as follows, under the name Microdon bellastriata, the species here termed Cypricardella bellistriata typicalis:

Much compressed, with very regular equal, concentric striæ; hinge margin slightly declining and nearly straight; posterior margin wide, direct; a slight fold anterior to and parallel with the umbonal slope.

Near Smyrna, Chenango County, New York. Upper Silurian shale [=Hamilton formation].

Hall, ${ }^{2}$ in 1885, gave many figures of the species, illustrating its widely variable form; his figures 10 and 14 very closely represent the form adopted by Conrad as typical of the species.

Two conspicuous varieties of the species may be recognized-one, represented by Hall's figures $7,8,15$, and 21 , in which the diameter from front to back is shorter than in typicalis, may be called $C$. bellistriata alpha; the other, represented by figures 16 and 17 and 11 , in which the same diameter is longer than in typicalis, may be called C. bellistriata beta. These two varieties are supposed to be true modifications of form, irrespective of the considerable modification produced by distortion. Such a form as Hall's figure 9 is imagined to have been produced by distortion of an original var. alpha, the crushing having shortened the umbonal ridge and relatively increased the distance from the posterior cardinal angle to the anterior ventral angle. Figure 22 shows distortion in a diametrically opposite direction; that is a shortening of the shell from the posterior cardinal angle to the anterior ventral corner and a lengthening of it along the umbonal ridge.

The Hamilton specimens figured on Plate VI (p. 98) of this paper exhibit the same differences in form; figures 5, 8, and 14 are fair samples of var. typicalis; figure 2 represents var. alpha; and figures 1 and 6 represent var. beta. Fluctuation in the strength of the concentric surface lineations is also observed; figure 1 exhibits the extreme in coarseness and figure 6 the extreme in fineness for the Hamilton specimens selected for illustration; the other specimens are intermediate and express the characters more frequently met with in Hamilton specimens. The shells are generally quite flatly compressed, but figure 5 shows a specimen not otherwise different preserved in markedly convex state. The relative position of the beak also varies, as may be seen by comparing figures 1 and 5; another specimen (fig. 14) from the same locality is still shorter in front of the beak.

Thus, in all of the elements of form and surface markings the Hamilton forms express distinct fluctuation.

PORTAGE FORMS.

The Portage specimens, all of which are from the lower recurrent zone (in the Ithaca member), express one constant character separating them from the Hamilton representatives varietally but not specifically. They are diminutive in size and their lineations are correspondingly finer, but in form they preserve not only the specific but the fluctuating characters of the Hamilton representatives. If it were necessary to use a name for this expression of the gens, Cypricardella bellistriata minor is appropriate. On Plate VI, figures 7, 9, and 10 show this peculiarity. Comparison of figure 9 with figure 5 makes evident the differences in size, for figure 9 represents the largest specimen from the Ithaca locality.

Figure 12 of a specimen from the same beds shows coarser lineations, linking it with typical Hamilton specimens. The specimen is seen by examination to be distorted and its shape can not be considered normal to the species.

1 Conrad, T. A., Jour. Acad. Nat. Sci. Philadelphia, vol. 8, 1842, p. 247, Pl. XIII, fig. 12

2 Hall, James, Paleontology: Geol. Survey New York, vol. 5, pt. 1, Lamellibranchiata, II, Pl. LXXIII. 
In the next recurrence, in the Tropidoleptus recurrent zone No. 2, where Cypricardella is associated with Tropidoleptus and other recurrent Hamilton species, the only definite modification I can detect is in the concentric lineations of the surface; these are less uniform than in the majority of Hamilton representatives of the species $C$. bellistriata. But the difference is slight, as will be noticed by examination of Plate VI, figures $13,15,16,17,18$, and 21 , all of which are of specimens from the zone No.2. Figures 15 and 18 differ little in this respect from the Hamilton expression in figure 8, but none of the figures from zone No. 2 show the remarkable evenness of lineation expressed by figures 1, 2, 3, and 4 from the Hamilton.

The artist has reproduced the characters faithfully, and a glance at the figures will show the difference. I am inclined, however, to think the difference is partly, if not wholly, due to difference in the nature of the sediments. The Hamil ton specimens come from a soft argillaceous shale, whereas the specimens from the zone No. 2 come from an arenaceous shale and had their surfaces somewhat broken in separating them from the rock matrix. The lineations, however, do not show the fasciculation characteristic of $C$. complanata and to some degree of C. tenuistriata. In form the specimens of zone 2 exhibit the varietal characters called typicalis, alpha, and beta, but no extremes of the variety alpha have been seen.

The specimens from the Tropidoleptus zone No. 3 show the characteristic concentric lineations; the two figures (figs. 18 and 20) show the types of var. typicalis and var. alpha. As in the Hamilton representatives, the lineations are sharply defined and regular.

SUMMARY.

The review of the characters shows that the limits of fluctuation expressed by the Hamilton representatives is not departed from in the later recurrent stages of the history. Local peculiarities and individual differences are expressed, but the specific characteristics are preserved with the same degree of persistence and the same fluctuations expressed by its representatives in the Hamilton formation.

\section{EUROPEAN OCCURRENCE.}

It is beyond the province of this paper to discuss the problems of nomenclature and taxonomy suggested by the sudden cessation, long disappearance, and evident return in force of the fossil fauna. It is also beyond it to attempt to trace the wanderings of the fauna into other regions of the earth during its absence from New York State. Nevertheless, a word may be appropriate in regard to the relationship between this recurrent fauna and the one fauna in Europe with which it seems to be in some way connected.

Beushausen ${ }^{1}$ in 1889 described the species Cypricardella elongata from the Lower Devonian in the Lower Coblentz strata of the Rhenish province of northwestern Europe. In 1895 he brought together descriptions and illustrations of several species of Cypricardella from which an opinion may be formed as to the expression of the genus, its faunal associates, and its range in the European Devonian.

The European cypricardellas are confined to the Lower Devonian, and the species C. elongata, which comes within the limits of variation recognized for $C$. bellistriata in the Hamilton formation in the United States is characteristically distributed in the Lower Coblentz zone, where it is associated with five other species of the genus and is preceded by three other species contained in the underlying Siegener zone. No trace of the genus is reported in any higher strata in the Rhenish locality.

The Lower Coblentz is the European zone at which Tropidoleptus appears; it is regarded by Frech ${ }^{2}$ as characterized by the genera Tropidoleptus, Rensselaeria, and Cypricardella.

1 Beushausen, L., Die Lamellibranchiaten des rheinischen Devon: $\Lambda$ bhandl. K. preuss. geol. Landesanstalt, n. s., vol. 17,1895 .

2 Frech, F. (Lethara palæozoica, 1897, p. 151), in describing the next following zone of Spirifcr paradoxus, remarks, "von den Leitformen der älteren Stufe sind vor Allem die Gattungen Tropidoleptus, Rensselaeria, sowie Cypricardella verschwunden." 
It is the so-called zone of Spirifer hercynix, and is generally supposed to be stratigraphically the equivalent of the Oriskany of the United States.

Whatever the formational correlation between the New York and European strata, close affinity undoubtedly exists between the recurrent fauna discussed in this paper and the lower Coblentz fauna of the Rhein. The faunas I have been dealing with are classified as Upper Devonian; the faunas in Europe with which this affinity is traced are classified as Lower Devonian. The facts are clear, and they involve the whole theory of correlation and of geologic synchronism.

In this connection the reader's attention is called to a similar combination of Oriskanian and Hamiltonian elements described by $\mathrm{me}^{1}$ from the fauna of the upper limestone of the breccia of St. Helens Island, Quebec. The fauna can not be regarded as the equivalent of either the Oriskany or the Hamilton, but its relationship with the Lower Coblentzian, which contains a mingling of the two, is apparent.

Such facts lead the paleontologist to be cautious in inferring from specific identity of fossils tbat the geologic time represented is the same for the formation holding them; and suggest that the farther separated two such formations are, geographically, the larger must be the time allowance separating the epochs in which they actually lived. If the whole of the Middle Devonian of Europe separates the epoch in which Tropidoleptus, Cypricardella, and Rensselaeria lived together from the epoch when the first Spirifer disjunctus appeared, the conceptions of the time relations expressed by the terms Eo-, Meso-, and Neo-Devonian must be modified to make the correlation between the two continents consistent with the paleontologic facts. It is one thing to discover a likeness of species and geologic faunas, quite another to infer that such likeness implies contemporaneity.

\section{TROPIDOLEPTUS ZONE OF THE ITHACA SHALE MEMBBER.}

I have left the consideration of the Tropidoleptus zone of the Ithaca member for special consideration until after the proofs of the recurrent nature of the faunas of the principal recurrent zones had been stated. I did this because the proofs in regard to the zone of the Ithaca member are less satisfactory; only faint and scattered traces of the pure Hamilton fauna are visible in its lower part, although the whole Ithaca fauna has a strong resemblance to the Hamilton fauna. The general Ithaca fauna expresses only general resemblance to the Hamilton fauna; the particular species as a rule are distinct and the associated species give to the fauna a characteristic expression quite distinct from that of the Hamilton.

The chief reason, therefore, for inferring that there was a definite return to the conditions which determined the particular combination of species of the Hamilton fauna, is the finding of a few diagnostic species of the later recurrent zones at the base of the Ithaca member. More minute investigation of the fossil contents of this lower part of the Portage may bring to light clearer evidence; but at present the evidence is suggestive rather than conclusive. If the recurrence of Tropidoleptus, Rhipidomella, and Spirifer marcyi be accepted as evidence of the return into the area of central New York of the conditions which determined the presence of the Hamilton fauna in the same area, the inference is strong that there was a partial return of those conditions in the early part of the general Portage epoch.

From the other evidence regarding the geographic distribution of the faunas concerned, this evidence should be more significant east of the Watkins Glen and Catatonk quadrangles than it is within that area.

So far as the life history of the genera is concerned, the samples taken from the zone in the Ithaca member may be safely regarded as intermediate between the typical Hamilton fauna and the fauna of the Tropidoleptus zone No. 1, the recurrence of which is established for this area. 
It is important to take cognizance of this sequence in any attempts to correlate the Hamilton formation by means of fossils. Evidence exists that the representation of the Portage (Manticoceras) fauna decreases on passing eastward. If it is found to disappear entirely as the beds are followed eastward (just as the Tully limestone and Genesee shale disappear), it may be necessary to recognize that an upper stage of the Hamilton fauna prevailed to the east during a stage of progress expressed farther west by the Portage fauna. In other words, the facts indicate that the Hamilton fauna somewhere persister in its integrity till after the close of Portage time as expressed in the Watkins Glen and Catatonk quadrangles.

The great difference in faunal contents between rocks of the Cortland and those of the Ithaca and Watkins quadrangles during the early stages of the Portage formation indicates the existence of some partial barrier, such as is admirably expressed by Schuchert, ${ }^{1}$ who pictures a tongue of the land, which he calls "Alleghania," running northeastward from Kentucky toward the center of Lake Ontario and separating the deeper waters connecting with the Atlantic in eastern New York from the Ohio basin of Ohio and western New York. Such a shallow barrier between deeper basins will account for the formation of the conspicuous ripplemarked flags deposited over central New York during the early stages of Portage time; and for the peculiar "channel fillings" (evidently the fillings of narrow tidal-flat runways) so characteristic of the early stages of the Portage rocks in some parts of the area.

Some such barrier, elevated temporarily into shallows, would account for the separation of the Buchiola-Manticoceras fauna, which is dominant for a longer period in the section west of the barrier than east of it, from the Tropidoleptus fauna, which in its recurrence is dominant for longer periods east of the barrier. It also may account for the marked alternation in occupation of the same area by the two faunas. The Ithaca fauna, although resembling in its generic features the Hamilton, was evidently separated and evolved separately from the pure Hamilton fauna in the Appalachian extension of the Mississippian sea. The invasion of the Tropidoleptus fauna was, I imagine, through the New Jersey trough from the Atlantic, in which it preserved its original characteristics far into late Devonian time. The appearance of a few representatives of the Tropidoleptus fauna in the Ithaca member indicates, it seems to me, occasional free access of the waters from the Atlantic into the northeastern end of the Appalachian trough, but not a free and continuous communication between the two basins.

The gradual elevation (signified by the estuarine sediments of Catskill type) probably closed the Appalachian trough at both ends and extinguished the marine Ithaca fauna before the New Jersey channel was closed; for the recurrent Tropidoleptus faunules of the zones Nos. 1,2 , and 3 are not modifications of the Ithaca fauna but of the pure Hamilton fauna.

I am thus led to the conclusions that the Tropidoleptus zone of the Ithaca member is (like the higher zones, Nos. 1, 2, and 3) expressive of a direct recurrence of the true Atlantic magna fauna during the occupation of the area by the general Ithaca fauna. The Ithaca fauna was evolved from the same magna fauna at an earlier time and entered the area through the Mississippian sea by a more southern passage. The Ithaca Tropidoleptus fauna entered the area, like the later recurrent faunas, through the New Jersey channel.

\section{EXISTENCE OF THE ZONES.}

\section{RELIABILITY OF THE EVIDENCE.}

Certain questions will naturally arise in the mind of a critical reader of this report. He will ask, for instance: What is known as to the presence or absence of the recurrent genera in other parts of the geologic section? What is there to show that these "zones" are not simply places in the sections where the collectors had the good fortune to find these fossils? May they not be common species of the Upper Devonian not before discovered? May not other species mixed with them be fully as important in the composition of the faunas as those selected for special notice? Is it not probable that these species would be met with more frequently if a closer examination was made of the fossiliferous beds lying between the particular zones reported? The justice of these and of a number of similar questions I have fully realized as 
I have written the report, and it is because they have met me at every stage of the investigation that I have been led to make so deep a study of the subject.

Whatever may be the true explanation of these recurrent zones it is of first importance to establish their existence beyond a doubt and to give the evidence of that existence in terms of fossils; and to establish this existence it is necessary to show that certain fossils are found in these zones and are not found elsewhere in the sections.

\section{EXAMINATION OF THE FAUNULES.}

\section{DIAGNOSTIC GENERA.}

A complete listing of all the species identified in the separate strata is a task which, even if accomplished, would be so vast and would cover so much ground that the evidence would fail because of its very abundance. I therefore restrict the table below to certain genera which I have found to be significant.

Over 1,400 individual faunules have been listed for the Watkins Glen and Catatonk quadrangles, and to these I have added 103 from the Cortland quadrangle so as to bring in some of the earlier stages of the recurrences. The distribution, by 15-minute quadrangles, of the faunules containing the 7 diagnostic genera, is shown in the following table:

Individual faunules collested and examined from the area.

\begin{tabular}{|c|c|c|c|c|c|c|c|c|}
\hline \multirow[b]{2}{*}{ Quadrangle. } & \multirow{2}{*}{$\begin{array}{c}\text { Number } \\
\text { of } \\
\text { faunules. }\end{array}$} & \multicolumn{7}{|c|}{ Number of faunules containing- } \\
\hline & & $\begin{array}{l}\text { Tropido- } \\
\text { leptus. }\end{array}$ & $\begin{array}{l}\text { Rhipido- } \\
\text { mella. }\end{array}$ & $\begin{array}{l}\text { Spirifer } \\
\text { marcyi. }\end{array}$ & $\begin{array}{c}\text { Del- } \\
\text { thyris. }\end{array}$ & $\begin{array}{l}\text { Camaro- } \\
\text { tœechia. }\end{array}$ & $\begin{array}{l}\text { Produc- } \\
\text { tella. }\end{array}$ & $\begin{array}{c}\text { Cypri- } \\
\text { cardella. }\end{array}$ \\
\hline \multirow[t]{2}{*}{ 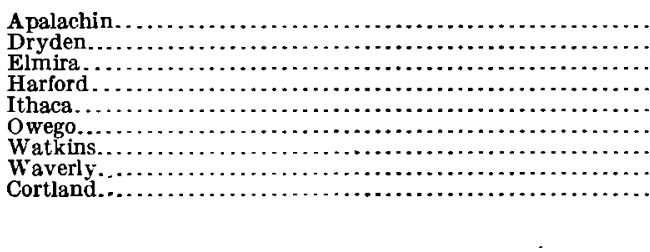 } & \begin{tabular}{r|}
63 \\
213 \\
117 \\
282 \\
152 \\
110 \\
126 \\
348 \\
103
\end{tabular} & $\begin{array}{r}7 \\
16 \\
1 \\
12 \\
1 \\
7 \\
73 \\
23\end{array}$ & \begin{tabular}{r|r}
2 & 20 \\
4 & \\
34 & 2 \\
4 & \\
22 &
\end{tabular} & \begin{tabular}{r|r}
3 & \\
22 & 5 \\
3 & \\
1 & 11 \\
11 & 34
\end{tabular} & $\begin{array}{r}10 \\
38 \\
37 \\
6 \\
5 \\
3 \\
5 \\
27\end{array}$ & \begin{tabular}{r|r}
11 \\
27 \\
17 \\
48 \\
16 \\
28 \\
5 \\
49 \\
13
\end{tabular} & $\begin{array}{r}11 \\
86 \\
49 \\
63 \\
68 \\
44 \\
29 \\
187 \\
15\end{array}$ & \begin{tabular}{r}
7 \\
5 \\
14 \\
30 \\
6 \\
6 \\
\hdashline 34 \\
14
\end{tabular} \\
\hline & 1,514 & 69 & $\overline{88}$ & 79 & 131 & 214 & 552 & $\overline{116}$ \\
\hline
\end{tabular}

In the first column the total number of separate faunules obtained from each quadrangle is indicated. In the other columns are given the numbers of faunules from each quadrangle containing the particular genus indicated at the head of the column. Attention is called to the fact that the faunules under each genus are not necessarily different faunules, for many faunules contain most of the genera named, and that there is no significance to the cross totals by quadrangles.

The faunules of the above table are separate samples of the fossil contents of the rocks. They furnish, of course, very meager statistics of the total fauna living at the time the strata in which they were obtained were being laid down, and of course they do not include species which did not live in the area at the particular stage of time they severally represent. Nevertheless, I believe that they furnish fuller statistics than have ever been gathered on this continent for a like section of Paleozoic rocks covering even so small an area as is here represented. They are the best evidence available, and the problem is to ascertain if they are capable of giving any positive evidence regarding the faunal succession which took place during this portion of Devonian time.

The last four genera named in the table are those that are shown, by examination of the several faunules in which the first three (diagnostic) genera are found, to be more frequently associated with these three than are any others, and also to be present in about 50 per cent of the sample faunules giving indication of these Hamiltonian species.

In the general study of the faunules I have considered the presence of two or three of the five species, Tropidoleptus carinatus, Rhipidomella vanuxemi, Spirifer marcyi, Delthyris mesicostalis, and Cypricardella bellistriata, as significant of the recurrent fauna, and have listed the faunules thus indicated and have given them special study. 
As already stated, in several cases the separate faunules collected from the same section and containing the same species, but a few feet apart, have been associated together as a single representation of the recurrent zones. The final samples, 63 in all, have been given serial numbers (see p. 10), and the same numbers have been applied to the list of species given on page 32. Examination shows that in 19 of the 63 zones (Nos. 16, 29, 33, 34, 36, 38, 39, 53, 55, $56,24,32,41,2,15,18,21,58$, and 59) the three diagnostic genera Tropidoleptus, Rhipidomella, and Spirifer marcyi are found together. In 24 others (Nos. 26, 27, 28, 30, 35, 40, 52, 54, 60, $3,5,9,22,42,1,10,13,14,17,19,20,25,43$, and 63 ) two of the diagnostic genera are associated. Thus in 43 of the 63 recurrent faunules at least 2 of the diagnostic genera are present. All but 1 of the remaining 20 contain at least one of the three diagnostic genera and other genera and species in sufficient number to indicate the presence of the same fauna. A single faunule (4) actually contains none of the diagnostic genera, but it contains both Cypricardella bellistriata and Delthyris mesicostalis and is at the position in the section appropriate for zone No. 3. It is also observed that in the Chemung Cypricardella bellistriata has been chiefly found only in the recurrent zones. The faunule has therefore been placed in the list. It is on this basis of facts that the recurrent Tropidoleptus zones Nos. 1, 2, and 3 are discriminated.

These zones, as already described, are situated (1) in the Portage formation, near the top of the Enfield shale member, (2) in the Chemung formation in the lower half of the Cayuta shale member, and (3) in the Chemung at the extreme top of the Cayuta member. At no other places above the Ithaca shale member of the Portage formation have any two or three of the generic types been found together. Tropidoleptus and Rhipidomella are not known to occur in the sections in the area except at one of these three zones; and Spirifer marcyi, with five possible exceptions, is not known to occur except within a few feet either below or above the horizon of the other two genera. The five doubtful occurrences out of a total of seventy-nine are all above the base of the Chemung, and the doubt regarding them arises from lack of evidence for determining their exact correlation.

In the sample faunules selected for study one or two may on research be found to be wrongly included, error having possibly arisen through the fact that $I$ originally regarded Cypricardella and Delthyris as equally certain indexes of this recurrent fauna with Tropidoleptus, Rhipidomella, and Spinifer marcyi. On final array of the evidence I found the presence of those two genera to be not positively diagnostic of these zones, although intimately associated with them, and I may have failed to weed out some samples included on their evidence.

In regard to Delthyris the evidence can be given only approximately at the present time, because of the difficulty of determining positively whether certain specimens examined are Delthyris or Spirifer pennatus posterus, as has been already explained in the discussion of the genus Delthyris (see p. 65).

Thus the evidence shows that there are three well-defined paleontologic zones (Nos. 1, 2, and 3), which are distinguished from other fossiliferous zones by the presence of the genera Tropidoleptus and Rhipidomella and the species Spirifer marcyi. The lower zone (zone No. 1) is further distinguished as the place in the sequence of strata at which the genus Delthyris first appears in the fauna above the Hamilton formation. Delthyris is a dominant associate with the other three genera after it appears, but it is not restricted to the recurrent zones as defined.

\section{ASSOCIATED SPECIES.}

Quite a number of other species in the faunal lists may be traced more or less directly to the Hamilton fauna for their direct ancestors. The following may be mentioned:

Pleurotomaria capillaria.

Palæoneilo bisulcata.

Ambocœlia umbonata.

Modiomorpha cf. concentrica.

M. cf. sublata.

Macrocheilina macrostoma.

Aviculopecten princeps.

Bellerophon brevilineatus.

\author{
(yrtina hamiltonensis. \\ Phthonia cylindrica. \\ Modiella pygmæa. \\ Limoptera macroptera. \\ Spirifer fimbriatus. \\ Phacops rana. \\ Macrodon hamiltonix. \\ Glyptodesma erectum.
}


Any attempt, however, to trace such species to the Hamilton discloses many others belonging to genera which have closely allied species in the Hamilton and which occur not only in the particular recurrent zones but also more or less continuously throughout the intervening strata of the Upper Devonian.

EVIDENCE THAT THE FAUNA IS RECURRENT.

CRITERIA OF RECURRENCE.

Proof of recurrence is more complex and difficult than would at first seem. It is very common to find the same genera or species in successive fossiliferous zones in a continuous section of rock strata. But such occurrence does not necessarily imply that the faunas recur in the section; it is more rationally explained as evidence of continuance of the fauna, its nonoccurrence in the intervening rocks being ascribed to interruptions of the record from one cause or another. Recurrence, as used in this paper, implies (1) the temporary withdrawal of the fauna and its replacement by another fauna, and (2) its later return to the area of first occupation. Both of these events have been established in regard to the Tropidoleptus fauna.

WITHDRAWAL OF THE FAUNa.

The withdrawal of the fauna is shown positively by the restriction of the three generic groups Tropidoleptus, Rhipidomella, and Spirifer marcyi to the particular zones and by their entire absence from the faunas between the zones (although those faunas have some other species in common and as faunas have a very similar general composition). Faunal life did not cease between the zones; on the contrary, it was abundant and, to casual observation, shows no break or noticeable change in general composition as it mounts in the strata. Nevertheless these three generic types appear together at certain horizons in the sections over the whole area, and are absent at all other horizons. Moreover, they appear in these zones not as single or rare specimens but in abundance.

RETURN OF THE FAUNA.

ABSENCE OF THE GENERAL FAUNA IN THE TROPIDOLEPTUS ZONES.

Regarding the interruption of the general fauna the evidence is certain. The species which constitute the dominant complexion of the fauna below and above the recurrent zones are generally lacking in the zones delineated by the diagnostic genera. But this is a general statement, and to make it particular or to infer that the general fauna has entirely withdrawn from the basin during the deposition of the recurrent zones would require deeper and more exhaustive study than I have been able to give. The present collected evidence consists only of a lot of sample faunules obtained from widely separated places and from widely separated horizons. Not only is the content of each local faunule extremely small, but the limiting causes are diverse. Only a handful of specimens was obtained from each fossiliferous ledge examined, and the ledge contained only such species as were accidentally buried and preserved at the particular square foot or so of the bottom examined. Hence not only the accident of finding and collecting but the imperfection of expression of the characteristics of the living fauna by the few preserved fossils make the testimony imperfect. Moreover, the relative rarity and abundance of the individuals of the several species in the fauna and their relation to the particular conditions of environment at the points from which the samples came make the samples extremely fortuitous as expressions of the total composition of the then living faunas.

Again, the possible modification of the species and the adjustment of their variable characters to differences in environment and the evolutional changes associated with successive stages of the race history complicate the problem; so that a slight deviation from the type form makes the discrimination of species uncertain. The study of the successive samples of any of the genera herein brought together indicate very strongly the importance of fluctuating variation. The investigations lead me to believe that the present definitions of many species 
are entirely artificial. Each genus must be studied in connection with the fluctuating variations normal to the several representatives living together in a connected area at the same time before the differences expressed by successive appearances of the race can be properly interpreted.

For the above reasons it has seemed to me useless to attempt by a preliminary listing of species as at present discriminated to prove either connection or nonconnection between the faunas of these particular zones and the general fauna of the Portage or the Chemung formation. Such relationship can be established, if at all, only after thorough study of all the evidence that can be gathered regarding the morphologic behavior of each single genus in relation both to its geographic distribution and its stratigraphic sequence.

\section{IDENTITY OF THE RETURNING FAUNA.}

Range of fluctuation. - The variations expressed in the recurrent zones by the several genera which constitute a dominant part in the faunal composition fall within the differing degrees of plasticity expressed by them in the Hamilton.

Tropidoleptus, though showing slight normal variational fluctuation, is remarkably persistent in form; specimens from the uppermost zone (No. 3) present no characters for distinguishing them from Tropidoleptus carinatus from the Hamilton, where it is an exceedingly common species.

Rhipidomella, to which I have given exhaustive critical study, shows the same remarkable persistence in the nature and extent of its normal fluctuating characters; examination of the specific differences by which the Hamilton representatives are differentiated in literature show these fluctuations persisting in the higher representatives of the recurrent zones.

Spirifer marcyi expresses the same persistence in fluctuation, not only in the generic characters but in the so-called specific details. At each stage the representatives of the species continued plastic; their fluctuating variations continued without settling down into any permanent specific combination up to the top of the Cayuta member of the Chemung, although a mutational character occasionally appeared which later assumed generic rank. $\mathrm{A}$ few specimens in the zones Nos. 1 and 2 show a rudimentary syrinx. Such specimens are associated with others in the same faunule like them in other respects but with no perceptible trace of the syrinx. A full study of the progressive assumption of this character is under investigation, and, so far as investigations have gone, appears to disclose a genuine evolution of a character regarded in literature as of generic rank. The other characters of Spirifer marcyi continue in the majority of specimens; the earlier syrinx-bearing forms are rare and appear at widely separate localities, and in these early forms the syrinx is rurlimentary.

All three of these generic forms (irrespective of the mutation expressed by the syrinx of Spirifer marcyi) show a high degree of constancy, both in the generic characters and in those plastic characters by which the variational capabilities of the race are expressed, during all that portion of the history of the races here under investigation. In this constancy of characters the three contrast with the other associated common representatives of the fauna.

Delthyris begins (after the Hamilton) to appear in the faunules of zone No. 1 (Enfield member of Portage). Specimens from that zone are generally less developed both in size and in the dominant characters of the race than are the later expressions of the race in the Chemung; and the species in the higher Cayuta member and in the Wellsburg member express decided differences from the earlier forms. These facts I have observed in the collections but have not made the necessary critical examination to enable me to state them in definite scientific form. Some specimens from the faunules from zone No. 1 differ extremely little from Delthyris consobrinus of the Hamilton. Several such faunules contain also other specimens not readily distinguishable from the typical Spirifer pennatus of the Hamilton; in these latter there is no trace in the pedicle valve of the median septum characteristic of Delthyris. These facts give reason for the hypothesis that such faunules represent a pure recurrence of a Hamilton fauna. But another fact comes in to vitiate this interpretation. The species Spirifer pennatus posterus (which in the original description was confused with Spirifer (=Delthyris) mesicostalis), is found abundantly in the Ithaca fauna; that is, in the lower Portage below the zone (No. 1) in the 
upper part of the Enfield member of the Portage. In no specimens of this Ithaca species has there been observed a definite septum in the interior of the pedicle valve, although there is always a faint line separating the muscular scars on the interior of the sinus of that value.

The abundant presence of this species, Spirifer pennatus posterus, below the Tropidoleptus zone No. 1, both in the typical Ithaca fauna and (in the Harford quadrangle) in the higher fauna in the strata succeeding the place of the Oneonta sandstone in the lower stages of the Enfield, suggests another hypothesis, namely, that the Delthyris of the zone No. 1 and of subsequent Chemung is a direct evolution, in place, from the Spirifer pennatus posterus. The solution of this problem will require a close, minute, critical examination of all the evidence, and this I have not yet been able to give. The investigation of these facts offers a fine opportunity to some student, for they seem to express a definite evolutional history.

The peculiarity which bears directly on the present argument is the continuance of the essentially unchanged form of Delthyris in the general fauna, after its apparent first arrival into the area, in association with its evolutional modification. The other three genera (Tropidoleptus, Rhipidomella, and Spirifer marcyi) find expression only in the restricted zones. The genus Delthyris, although coming in with the first of the zones, did not withdraw, but remained upon the ground. The inference is that something happened which terminated the existence of the three genera but did not drive out Delthyris. The remaining of Delthyris, after the departure of Tropidoleptus, Rhipidomella, and Spirifer marcyi, is evidently associated with some changed condition of environment. The three forms which exhibit rigid adherence to their ancestral modes of development suddenly came and as suddenly departed, but the other form, Delthyris, suddenly appears, remains on the ground, and changes its forms. It is probable that the first three groups of species were closely adjusted to a narrow range of environmental conditions and migrated with them; the fourth group, having its origin in a region of restricted conditions, moved in with the other three, but was capable of adjustment to the new conditions after the withdrawal of the particular normal conditions under which it previously lived. This argument, though hypothetical, agrees with the general evidence, for it assumes that an actual recurrence of certain, at present unknown, conditions of environment was the cause of the appearance in the sections of that peculiar combination of species called the recurrent Tropidoleptus fauna.

Racial continuity.-The three generic forms so diagnostic of the recurrent zones are each of them characteristic representatives of the normal Hamilton fauna. Tropidoleptus and Rhipidomella are abundant throughout the whole Hamilton formation, and Spirifer marcyi abundant in some of the beds of the upper Hamilton. Their identity with the Hamilton forms is established by their persistence in retaining not only generic but fluctuating variations, for it must be borne in mind that the continuity of a race is established only by evidence of continuous reproduction of the same characters. The instant modification of characters begins in a series of extinct organisms the thread of continuity is broken. This is the reason why it is necessary to deal with so-called generic characters first. It is essential to establish genetic continuity of the representatives of the race before it is practicable to discuss the modifications which the race has undergone in its genetic history. Herein lies the great sjgnificance of establishing the recurrence of a fauna. It is a simple matter to discover differences between representatives of the same genus at successive stages in the geologic column; but if those differences are found to be absolute (that is, if a species in one zone is found constantly to develop a character not expressed by the related species of a lower zone) then the question as to whether they are genetically continuous arises. The reason for the uncertainty lies in the lack of evidence as to whether the new species lived in some other region contemporancously with the first species and was introduced by migration, or was directly evolved, in place, by evolutionary modification of characters from the earlier species.

It is illogical to assume that the particular modification has taken place by direct genetic evolution until it has been clearly established that faunal continuity has existed. As faunal continuity can be established only upon evidence of repetition of the same characters, it becomes 
necessary to trace a generic group upward through the series of deposits; because the fluctuation shown by each such generic group, and expressed by the representatives of the group living together in the same faunule, includes characters which have been used in discriminating the separate species within the genus. Any combination of characters which is possible to a genus at one stage of its existence (as expressed by the individuals living at that one stage under similar environmental conditions and as recorded by the fossils of a single faunule) must be considered as possible of expression in the fossils of a later stage without disturbance of the genetic continuity of the race. On the other hand, any addition to or subtraction from the characters expressed at one stage which makes its appearance in the forms at a higher stage may be mark of a separate group of the genus-separate in its adjustment to environmental conditions and separate in its areal distribution. And such separateness may date back to a point in racial hiatory earlier than the first stage used in the comparisons. The chief problem, therefore, is to trace racial continuity.

Theoretically, all the representatives of a genus may be supposed to have a common ultimate origin. At each stage in their history a certain amount of diversity in form is theoretically assumed to be normal to the race at that stage of its evolution. Practically, the amplitude of such diversity of form is assumed to be expressed by the group of individuals living together at the same stage and thus by the fossils found in one faunule. In tracing the continuity, therefore, into successive zones it is not specific identity that it is essential to establish (for specific identity is not required among the representatives of the single faunule); it is inclusion within the amplitude of fluctuation of characters expressed by all the individuals representing the genus in the particular faunule on which the conception of the racial integrity at that particular stage in its history must be based. If such a group of individuals is found to consist of separate subgroups of individuals not connected by fluctuating variation, it is necessary to restrict the generic group to that subgroup, no matter what it is called in descriptive literature. Thus, in the present discussion and for the purposes of this discrimination of natural groups of individuals, Spirifer marcyi is a natural group of individuals having fluctuating variation; just as Tropidoleptus or Rhipidomella are natural groups expressing themselves in fluctuating variations at each stage under investigation. Other spirifers (such as Reticularia lavis, Spirifer pennatus posterus, Spirifer mesistrialis, and Spirifer disjunctus), which in literature are classified as species, possess distinguishing characters not possessed by the others. The question as to whether these distinctive characters are of specific or generic rank does not enter. The diagnostic characters of each "species" may be fluctuating characters for the individuals constituting the "specific" group to which they belong, or they may appear to be nonfluctuating; in either case, so long as the amplitude of their fluctuation for the particular stage does not lap over the amplitude of fluctuation of similar characters for the other "species," the individuals possessing them constitute essentially one generic group. Evolutionally and morphologically the only valid distinction is as to the presence or absence of a character. For purposes of classification specific, generic, or ordinal rank may be ascribed to specimens possessing this, that, or the other character; but in an attempt to trace genetic lines all individuals possessing a particular character, even in a rudimentary condition, must be positively distinguished from all forms not possessing it. Every such character becomes a means of discrimination between individuals, however fluctuating in size or form it may be in the group of individuals holding it. The only limit separating one continuous race of individuals from another must be drawn in terms of such positive characters. The line of distinction must be drawn on the basis of actual absence or actual presence of a distinct definable character, and not on fluctuating characters except where the gap in the amplitude becomes itself a definite boundary separating distinct groups of individuals.

On the Darwinian hypothesis that specific distinction arises by fixing in one part of a race the limit of fluctuation of a character, racial groups must be conceived to break up into subgroups which do not mix with each other. On this hypothesis the formation of a new species will be expressed in fossil specimens by the definite appearance at some particular geologic stage of a gap in the fluctuating characters for a series of individuals living together at the same 
time as found expressed in a single faunule. The existence of such a gap must be expressed in the terms I have outlined and will be shown by the different degrees of development of some common part. Until, however, the limit of the fluctuation can be discerned no evidence of nonmixing of the two subgroups can be established. Hence, unless the gap in the fluctuating series continues to be exhibited in later stages of the racial history no "specific" grouping can be established. And when the gap is thus shown to be permanently established the difference is indistinguishable from the differences called "generic," so far as it can be defined in terms of morphology. The difference, therefore, between "specific" and "generic" becomes not one of facts capable of observation and of definition in terms of morphology, but one of theoretical interpretation of facts.

\section{CONCLUSIONS AS TO RECURRENCE.}

The establishment of the fact that the three zones under consideration contain at least three well-defined generic groups which are identical for the several zones and for the Hamilton formation gives a rational ground for the theory of recurrence. No other theory that I can at present formulate will explain the presence of these generic groups in these particular zones and their absence elsewhere in the formations above the Hamilton in which these zones occur. And this reasonable basis for the general theory of recurrent zones having been established, it may reasonably be extended to include the zone near the base of the Ithaca member on the basis of the occasional discovery there of two at least of the diagnostic generaTropidoleptus and Rhipidomella.

\section{STRATIGRAPHIC EXTENT OF THE ZONES.}

The exact stratigraphic limits of the faunules at each of the zones is not yet certain. The Tropidoleptus zone No. 3 appears to be limited in range to less than 10 feet thickness of strata. The zone No. 2 in some outcrops appears to be also narrow, but in the section at Waverly it seems to comprise several thin zones spaced at intervals of 10 to 20 feet. In the Harford quadrangle the recurrent faunule of zone No. 1 has been detected at three or four separate horizons ranging through at least 100 feet, although in the section at the typical locality (Van Etten) it appears to be not over 20 feet thick.

\section{OSCILLATION OF THE RECURRENT FAUNA.}

The facts seem to indicate that the introduction of the particular fauna associated with Tropidoleptus was not due to a sudden change of conditions, lasting for a brief time only and as suddenly withdrawn. It seems rather to have been associated with some gradual change in the conditions affecting the general highway by which this foreign type of fauna found congenial access to the area-a change which opened a ready passage from the foreign center of distribution. This opening reached its climax at the point in time when the conditions appropriate to the life of this (Tropidoleptus) fauna dominated those normal to the previous occupants of the area. The two sets of environmental conditions for a long time oscillated back and forth and finally the conditions appropriate to the foreign fauna were wholly withdrawn, the recurrent fauna retreated, and the normal fauna again occupied the area.

This is about as far as the recurrence hypothesis can be elaborated on the basis of the actual collected facts. Very many other suggestions arise, to scientifically establish which the ground must be further examined and new facts gathered.

It is not to be understood that the fauna of the seas recorded by the zones totally differed from that of the seas recorded by the strata above and below the zones. The facts signify rather that the succession of the marine faunas was due, not to a uniform continuous progression of conditions, geographic and geologic, but rather to an oscillation back and forth of opposite or contrasted conditions.

The recurrent zones are expressions of the climacteric or nodal points in these oscillations. For long periods prior to the appearance of the diagnostic genera the conditions were leading up to those essential to their existence. During this preparatory period one after another of 
the more hardy species reached the area. In the same manner, after the climacteric point was past and the direction in change of conditions was reversed, one and another of the species of the fauna was cut off by adverse conditions of environment and other more hardy species continued to live. Some of the more hardy, with the changed conditions, exhibited their hardiness by modifying their characters, and these remained after the alternate set of conditions had changed the composition of the fauna.

To make the problem simple: Suppose the two sets of faunas were simply Arctic and tropical faunas, such as are now seen along the eastern coast of America. Suppose the difference in the faunas to be determined primarily by the temperature of the water. Geologic changes of a general character might take place, resulting in the gradual dominance of the cold waters from the Arctic Seas until the total inhabitable marine waters at a particular shore (say Nova Scotia) had become as cold as those of the Arctic regions. Not only would the faunal life of the shore contain species peculiar to the Arctic faunas, but, finally, it would cease to include all species of the more southern faunas not adjustable to cold waters. During the process of change members of the Arctic fauna capable of a wide range of temperature would from time to time migrate to the area, but the strictly Arctic species would not enter in abundance and would not dominate the fauna till full Arctic conditions prevailed throughout the year.

After Arctic conditions had reached a climax, suppose geologic changes should occur that would reverse the process and gradually throw warm waters farther and farther north. The time can be imagined when the conditions off Cape Hatteras would prevail off the shores of Nova Scotia. The effect on the fauna would be gradual if the geologic changes were gradual, and when the change had become such as fully to replace the Arctic waters by those having Hatteras conditions of temperature the fauna living (and therefore recorded in the deposits made) would be of the Hattoras type.

This is a simple illustration of what might be expressed by the fossil faunas under the complex conditions of change existing during the latter half of Devonian time in the Watkins Glen and Catatonk quadrangles. The recurrent faunas demonstrate some such oscillation in environmental conditions, although the cause and nature of the oscillation is at present unknown.

\section{SIGNIFICANCE OF RECURRENT FAUNAS.}

\section{DIASTROPHISM.}

The wide significance of this study of fossil faunas in interpreting the past geologic history of the globe is now appreciable. Other phenomena have led geologists to believe that the particular relations between land and sea now determining the geographic conditions of the earth's surface are but temporary. The continental masses of land are in great part composed of materials laid down in the ocean and arranged by processes now chiefly performed below the surface. Thus it is necessary to assume that the lands have been elevated by diastrophic movements above the position, relative to ocean level, which they originally occupied. At first geologists imagined that the ocean had retreated; but wider study made it evident that there is no place on the earth or in it to which the waters could retreat. The logical explanation of change of altitude between the surface of the rock and the surface of the ocean is that the general ocean surface is geologically the more stable of the two. The widely accepted and consistent hypothesis is that continental elevations have been associated with corresponding depressions of the ocean bottoms so far as their vertical relation to the ocean surface is concerned. The depth of the ocean basins has increased as their surface area has decreased in order to preserve the cubic capacity of the ocean constant. Further study of the problem, as an earth problem, has developed the fact that the elevation of continental masses has not been uniform either geographically or chronologically. At the present time some parts of the continents are rising and other parts sinking.

One of the most important results of these studies has been the framing of a hypothesis by which the events in the geologic history are directly ascribed to movements upward and downward of the solidified earth crust in relation to sea level. According to this hypothesis 
transgression of the sea over the land surface shows that the land is sinking; whereas its withdrawal from the land, thus extending the surface seaward, shows that the land is rising.

\section{GEOLOGIC EVIDENCES OF DIASTROPHISM.}

Evidence of such transgression and retreat (and therefore evidence of diastrophic movements) is expressed, in a general way, by the sedimentary rocks formed during their progress. The s!ccession of the physical characters of the sedimentary deposits recorded in a particular rock section indicates whether the sea was transgressing upon the land or was withdrawing. The interpretation of the facts is based on the general law that the coarser the sediments the nearer they must be to their place of origin or formation under uniform conditions of sedimentation. Thus, in general, a section containing at the bottom coarse conglomerates followed by sands with finer and finer grain indicates increasing depth of the waters in which the sediments were deposited, ${ }^{1}$ and therefore indicates a gradual increase, during the period of the record, in the distance from the point where the section was made to the then existing margin of the sea in which the sediments were being deposited.

If the order of the deposits is reversed (that is, if the physical size of the particles making up the rock increases progressively from the bottom up) the presumption is strong that during the period of sedimentation the sea was becoming shallow, or the place of deposition was becoming nearer to the land with progress of time.

All through the geologic columns of all regions such changes in the sediments have been observed, the change in character of the sediments indicating in some places one kind of diastrophism and in some places another. It is thus certain that diastrophic movements have been taking place as the sedimentary rocks have been formed.

\section{TIME RELATIONS OF DIASTROPHISM.}

\section{LITHOLOGIC EVIDENCE.}

The fact of diastrophism is unquestioned, but the determination of the position of the shore at any particular geologic time necessitates correlation in time of the records at each particular locality. Increasing depth may be expressed by the lithologic character of the sediments at locality $A$ for a time sufficient for the accumulation of 1,000 feet of sediments; and similar increasing depth, with the same accumulation of sediments, may be shown at locality B, 50 miles to the north of $\mathrm{A}$; and yet nothing in the character of the sediments alone can certify that the diastrophic movements recorded took place at the same time for the two localities. The physical composition of the sediments is determined by the land from which the materials are derived by erosion, and if the rocks are the same it makes no difference at what geologic age they are ground up and deposited. The lithologic character of sediments, formed at similar rates, by similar modes of erosion, and under similar conditions of transportation and sedimentation will be the same. On the other hand, if the sources of the materials are different the lithologic character of sedimentary rocks deposited under like conditions and at the same time will differ. The chemical constitution, also, of sedimentary rocks, is determined by the chemical constitution of the preexisting rock material out of which the sediments were formed; and this law is constant for all stages of geologic time. Also, the physical size and arrangement of the particles of sedimentary rock are determined by the physical properties of the original material and their weight relative to the specific gravity of water, for the general laws of erosion, transportation, and sedimentation have been theoretically alike in their operation and effects through all geologic ages from the Cambrian up to the present time.

Although it is found expedient in classifying rock formations to apply names on the basis of lithologic uniformity, it is unscientific to maintain that such uniformity implies contemporaneity of deposition of the sediments making up the formations. Contemporaneity, indeed, may

\footnotetext{
1 Or it may mean changes in climate or in currents or in the topography or lithology of the adjacent land surface which is being eroded.
} $67437^{\circ}-$ No. $79-13-6$ 
be expressed by geographic diversity of sedimentation, for sedimentation at different distances beyond the coast and at different depths could scarcely be uniform. Approximate uniformity of the physical constitution of the sediments might be expected to prevail for long distances parallel to the original coast line; and if the sinking of the land kept pace with the deposit of the sediments this uniformity of physical constitution might continue for an indefinite period of time. Uniformity in the lithologic character of the sediments parallel to a shore line may roughly signify contemporaneity of deposition, but uniformity at right angles to a shore line suggests progressive change in level or diastrophism. Conversely, it follows that it is only where uniformity in the physical character of the sediments can be shown by independent evidence to extend at right angles to the shore line that it can be interpreted as evidence of diastrophism.

\section{FAUNAL EVIDENCE}

It is because of the impossibility thus pointed out of deriving from the lithologic characters of sedimentary rocks alone any positive indication of their geologic age, that the geologist is obliged to consult the evidence furnished by fossils in order to determine not only the fact but the character of the diastrophism. The faunas of the recurrent zones, herein discussed, give positive evidence not only as to the stage in geologic history at which the zones were deposited but also by their difference from the faunas contained in the consecutive beds strongly suggest general orogenic movements such as the geologist characterizes by the term diastrophism. From the Hamilton up to the Chemung for this region a gradual but intermittent change takes place from fine mud shales to moderately coarse sandstone, suggesting a gradual shallowing of the seas in which they were deposited. This difference in lithologic characters of the sediments took place at an earlier date in the eastern part of the area than in the western part. But the establishment of the time relations requires the evidence of fossils.

In figure 2 (p. 24) an oblique line, indicated by the words "Base of Chemung type of sediment;" is drawn from the base line of the Cayuta member of the Chemung formation to the top of the Oneonta sandstone. This line is an attempt to express, by current methods of classification and mapping, the actual facts regarding the contemporaneity of geologic events in the area under discussion, as brought out by a close inspection of the fossil faunas.

The facts were first outlined in $1885 .^{1}$ I then stated that the Catskill type of sedimentation began in the eastern part of the State immediately above the Hamilton formation as expressed in terms of the faunas. In the middle part of the State this type of sediment did not appear until after Portage faunas had made their record in the sediments, and in the western part of the State not till after the Chemung faunas had received full expression. Catskill sedimentation, it may be explained, is a term indicating a condition of the environment which affected the general nature of the fossil faunas. In the Catskill sediments almost all fossil evidence of marine conditions has disappeared, leaving the rocks in sharp contrast with the ordinary Upper Devonian sediments holding typical marine faunas.

CORRELATION OF LITHOLOGIC AND FAUNAL INDICATIONS.

In the Watkins Glen and Catatonk quadrangles the same conditions are expressed by the general marine faunas among sediments in which the lithologic differences are slight. The oblique line in figure 2 (p. 24) is an attempt to give the field geologist a lithologic means of recognizing the passage from the Portage to the Chemung in the eastern sections where by paleontologic evidence the passage from the Portage fauna to the Chemung fauna does not take place until higher up in the section.

The geologist who is accustomed to trace the outcrops of a formation across the country by means of uniformity of sediments is thus given a guide by which he may recognize in the eastern part of the State the base of the Chemung as it is defined in the western part (fig. 2); and the diagram points out that the passage is geologically lower (or earlier) at the east than at the west. The basis of this determination of historic stage in geologic events is the paleontologic record; the figure is designed to furnish a concrete example of the problem for intelligent discussion.

I On the classification of the Upper Devonian: Proc. Am. Assoc. Adv. Sci., vol. 34, 1885, pp. 222-234, with chart. 
CONTEMPORANEITY OF DEPOSITION.

LITHOLOGIC EVIDENCE.

Heretofore horizons expressed by geologic formations have been accepted as synonymous with epochs of geologic time. In the discussion of problems of paleogeography it is important to note that this is true only in a general way. The comparison of fine shales with conglomerates at once suggests wide differences in the conditions of sedimentation which may be readily interpreted as resulting from differences in distance from the original source of the sediments. But the laws of diastrophism and their use in reconstructing the geography of the surface require knowledge not only of the existence of changed or changing conditions but also knowledge as to the direction in which the change is advancing.

To interpret direction it is essential to establish contemporaneity of the records compared. Two localities may expose outcrops of a similar conglomerate, but it is necessary to show that they are contemporaneous to prove that a line connecting them expresses a shore line of the sea of the time when they were formed. Everywhere it is to the fossils that reference must be made for direct evidence of contemporaneity. And the lines by which paleogeographic lands are outlined have rational meaning only so far as the rocks along them are supposed to be contemporaneous.

\section{FAUNAL EVIDENCE.}

The primary reasons for supposing that fossils are capable of testifying positively as to the geologic age of the deposits holding them is the observed change in the fossil contents of the rocks in successive strata. This change is observed not only in the morphologic characters of the fossils but in the composition of the faunas.

\section{COMPOSITION OF FAUNAS.}

The change in representatives of the same genus or species is not so rapid nor so uniformly expressed as is the change in the combination of associated fossils making up faunules of the successive zones in the rocks.

The faunal differences which strike the eye of the field geologist in contrasting fossiliferous slabs from two different formations are generally generic and not specific. The untrained observer is not likely to notice the slight modifications of form in the same genus associated with successive stages in its evolutional history; and a great many marine invertebrates of the Paleozoic representatives of the same generic race, separated by several formations from each other, might easily be confused and regarded as the same except by an expert paleontologist. But modifications of the fauna, as expressed by changes in the relative abundance, the presence, and the absence of particular forms, and by the more or less vigorous growth and varying size of individuals, are very sensitive indications of changed conditions of environment. For measuring short lapses of time and close contemporaneity they are much more significant than is the specific identity of a single species.

It must be constantly remembered that the observed slight differences in form by which two closely allied species are distinguished by no means signifies that one is necessarily descended directly from the other. The differences may have been established at an earlier stage in the racial history than is indicated by the individual samples under comparison; also, the differences may be normal, fluctuating variations indicating only different conditions of environment of which the samples are an adjusted expression. In the case of fossils, of which the continuous history is extremely deficient, knowledge of the amplitude of fluctuation is very small, and it is impossible to rely on even the closest similarity in form of two samples alone as indicative of the same age, for it has been shown by other evidence that such similarity may occur in samples separated by hundreds and even thousands of feet thickness of strata.

Where a recurrent fauna, such as $I$ have been describing in this report, consisting of several associated species, suddenly intrudes itself, with its characters intact, into the midst of a general fauna with which it shows slight community of composition, it furnishes a record 
which has positive time value, because the continuity of generation of the recurrent fauna is attested by its contrast with the faunas that separate it in a continuous geologic column from the formation in which its earlier appearance is recorded.

CHANGES IN FAUNAS.

So long as a particular fauna continues to mark the successive strata of a local geologic section, it is reasonable to infer that the life environment of the fauna remained reasonably constant in the area. It is also reasonable to infer that change of the faunal constitution of the fauna marking the strata is indication of a change of environment forbidding continuous generation of the species of the fauna. The point in time indicated by the change from one fauna to another is necessarily definite, being made so by the two contrasted faunas, one of which ceases and the other begins to occupy the particular area. Owing to the universality of diastrophic movements the point of time when one fauna suceeds another differs with locality. But in any one place the difference in time becomes apparent when the earlier fauna recurs.

\section{RECURRENCE OF FAUNAS.}

In the Watkins Glen and Catatonk quadrangles there are three recurrences of the Tropidoleptus fauna at places in the general section made apparent by their relation to the general fauna into which they are intruded. The slight difference in time incident to transgression from one place to another becomes also expressed by the fossils, showing the direction of the movement by which the change in the faunas was produced. If the forms diagnostic of these recurrent zones had become modified sufficiently to change their identity it would be impossible to speak with certainty as to the continuity of the race. If they had not recurred in these successive zones, the time signified by each zone could not be affirmed. It is the combination of continuity of the Hamiltonian fauna and its expression at definite stages in the history of the succeeding Portage and Chemung faunas that gives this recurrence its significance. The species themselves are shown to be long lived as measured by geologic formational time; but the event in their history expressed by their recurrence marks a definite point in geologic time which occurred but once with the same relations; its repetition is marked by changed relations. The place and time of each particular diastrophic movement is fixed by the fossil records, and I fail to see any possible means of recording the time identity (contemporaneity) of such movements in other parts of the world except by the fossil records. 
PLATE I. 


\section{PLATE I.}

\section{Tropinoleptus carinatus (Conrad).}

A series of specimens from a single bed (Hd. $13 \mathrm{G}, 1 r$ ) in zone No. 1 (in Enfield shale member of the Portage formation), at Harford Mills. U. S. Nat. Mus. Cat. 59603.

Figures 1-27. Molds of the interior of pedicle valves.

Frgures 28-38. Molds of the interior of brachial valves.

Frgures 39, 42-64. Molds of the exterior of brachial valves.

Figures 40,41 . Molds of the exterior of two small pedicle valves.

FIgUres 42-44, 46, 55. Molds showing initial convexity followed by outward curvature, making general concavity of the mature shell, as in figures $48,53,59$, and 60 .

Figure 47. Mold showing in extreme the wide cardinal part of shell and the rapidly narrowing sides characteristic of var. $z$ eta.

Figures 59,63, 64. Molds showing decided geniculation outward of the shell of the brachial valve. 


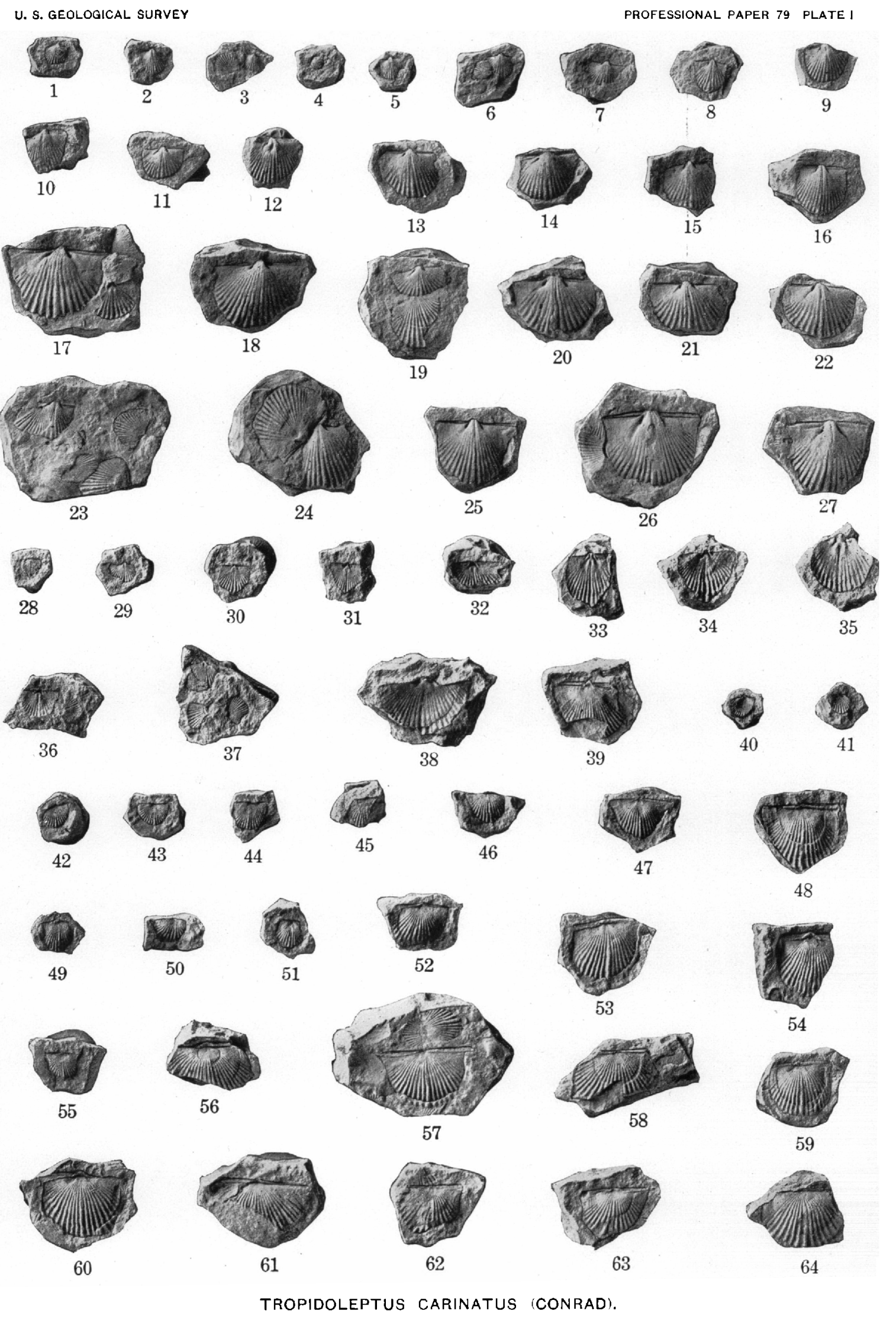



PLATE II. 


\section{PLATE II.}

\section{Tropidoleptus carinatus (Conrad).}

Figures 1-24. Molds of the exterior of brachial valves of normal flattened forms belonging to the series repre. sented on Plate I. All from a single bed (Hd. 13G, $1 r$ ) in the zone No. 1 (in Enfield shale member of the Portage formation) at Harford Mills. U. S. Nat. Mus. Cat. No. 59603.

Figures 25-27. Mature specimens of pedicle valves showing characteristics of var. typicalis. From the Hamilton formation from Kashong Creek, N. Y. U. S. Nat. Mus. Cat. No. 59604.

Figure 28. Mold of the exterior of a brachial valve of var. alpha. From Hamilton formation, Brookfield, Madison County, N. Y. U. S. Nat. Mus. No. 59605.

Frgure 29. Mold of the exterior of a large brachial valve showing a decided sulcus, involving three plications toward front of the shell. From Hamilton formation of Brookfield, Madison County, N. Y. U. S. Nat. Mus. Cat. No. 59605 .

FIgURE 30. Mold of exterior; shows also the interior along the hinge line of the brachial valve. From Hamilton formation, Smyrna, Chenango County, N. Y. U. S. Nat. Mus. Cat. No. 59606.

Figure 31. Mold of the exterior of a brachial valve of var. typicalis. From Hamilton formation, Sherburne, Chenango County, N. Y. U. S. Nat. Mus. Cat. No. 59607. 
U. S. GEOLOGICAL SURVEY
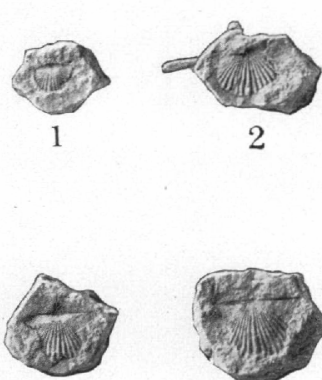

7
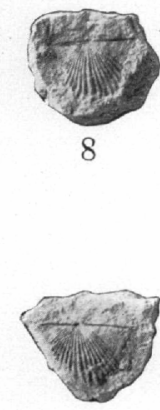

14

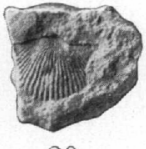

19

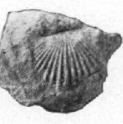

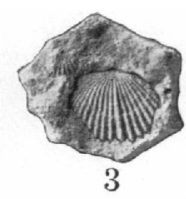
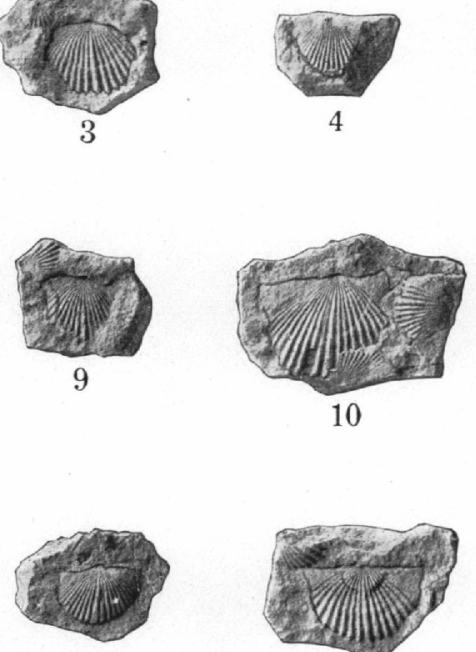

15

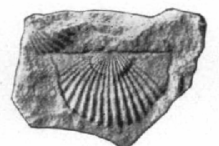

16
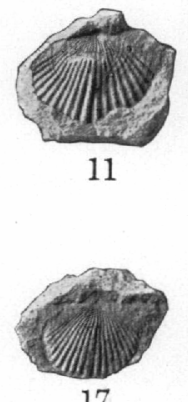

17
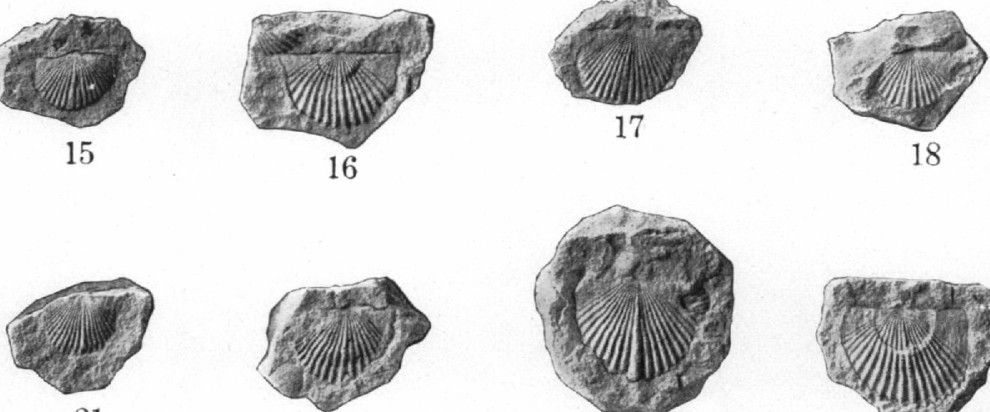

21
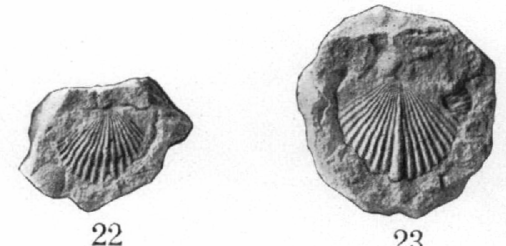

23

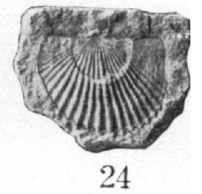

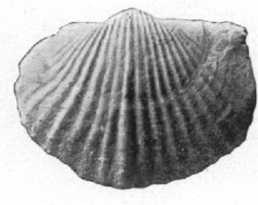

25

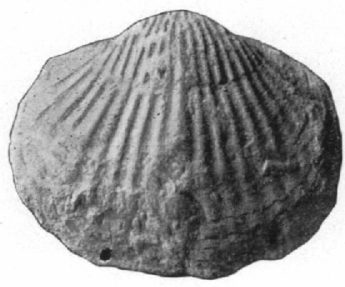

26
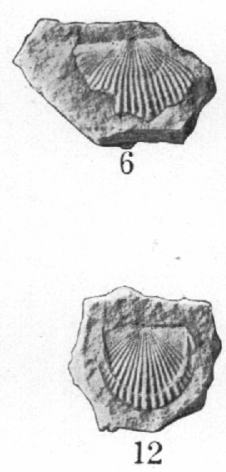

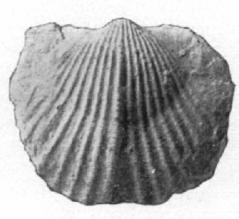

27

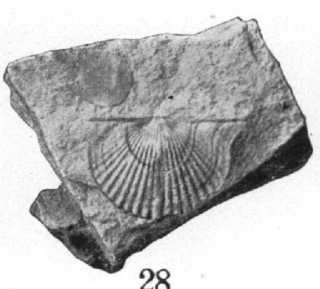

28

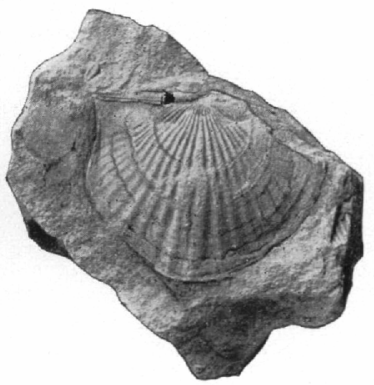

29

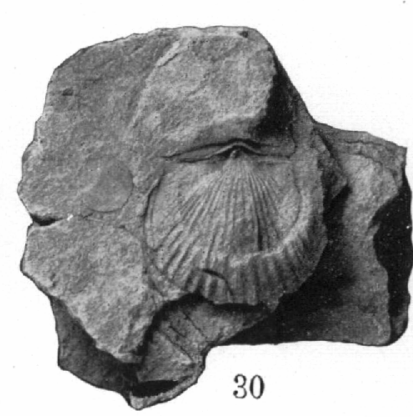

30

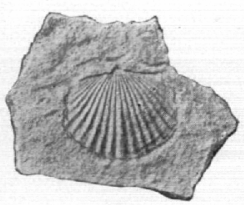

31

TROPIDOLEPTUS CARINATUS (CONRAD). 

PLATE III. 


\section{PLATE III.}

\section{Rhipidomella vanuxemi Hall and Varieties.}

Figure 1. Rhipidomella vanuxemi Hall. Mold of the interior of a pedicle valve, showing the form and muscular impressions. This is a fairly normal expression of typical $R$. vanuxemi (cf. Paleontology: Geol. Survey New York, vol. 4, Pl. VI, fig. 3m). From Hamilton formation, shore of Cayuga Lake, central New York. H. H. Smith, collector. Cornell University Museum 9139.2 .

FIGURE 2. Rhipidomella vanuxemi Hall. Mold of interior of pedicle valve, showing the left side of the shell with form of $R$. vanuxemi, the right side with form of $R$. penelope, and the center lobes of the muscular scar produced forward as in specimen figured in Paleontology: Geol. Survey New York, vol. 8, pt. 1, Pl. VI, A, fig. 8. From Hamilton formation, shore of Cayuga Lake, central New York. H. H. Smith, collector. Cornell University Museum 9139.4.

Figure 3. Rhipidomella vanuxemi Hall. Mold of interior of pedicle valve, compared with typical $R$. vanuxemi. This shell is much more convex on the umbonal region, is narrower, and has its greatest width lower down (as in $R$. leucosia). The muscular scar is also smaller and narrower than normal. From Hamilton formation, shore of Cayuga Lake, central New York. H. H. Smith, collector. Cornell University Museum 9139.3.

FIGURE 4. Rhipidomella vanuxemi Hall. Mold of interior of pedicle valve. The muscular scar is strongly impressed, not fanlike as in typical $R$. vanuxemi; the center lobes are strnng though not produced forward of the boundary of the main scar. From Tropidoleptus zone No. 1, in Enfield shale member of Portage formation. (Dr. 3D, 1o, U. S

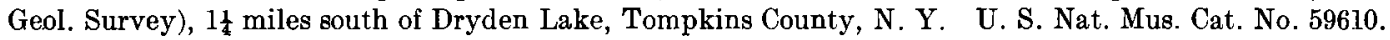

Figure 5. Rhipidomella vanuxemi Hall. Mold of the interior of a pedicle valve of medium size, somewhat flattened in the rock. Shell structure thin; muscular impressions faintly expressed and relatively small in size; form that of normal $R$. vanuxemi of corresponding size. From Ithaca shale member of the Portage formation, at the foot of Buttermilk Creek, South Ithaca, Tompkins County, N. Y. E. M. Kindle, collector. Cornell University Museum 10457.

FIGURE 6. Rhipidomella vanuxemi Hall. Mold of the interior of a pedicle valve, with a small and unsymmetrical muscular scar; front center of the shell produced more than normal. The lobes of the muscular scar on the right side are faintly divided and normal in shape; those on the left abnormal and separated by strong ridges. From zone No. 1 in Enfield shale member of the Portage formation (Hd. 13G, 1s, U. S. Geol. Survey), Harford Mills section, south of Harford, Cortland County, N. Y. L. Reinecke, collector. U. S. Nat. Mus. Cat. No. 59611.

FigURE 7. Rhipidomella cf. penelope Hall. Mold of the interior of a pedicle valve exhibiting the outline of $R$. penelope in its broad flattened shell, and in the finely subdivided lobes of the muscular scar, but showing the boundaries of the muscular scar faintly impressed. From Tropidoleptus zone No. 1 in Enfield shale member of the Portage formation (Ow. 9A, 1l, U. S. Geol. Survey), west of North Candor, Tioga County, N. Y. V. H. Barnett, collector. U. S. Nat. Mus. Cat. No. 59612.

Figure 8. Rhipidomella vanuxemi Hall. Mold of the interior of a pedicle valve from the same fauna as figure 6; showing an abnormal development of ridges separating the lobes of the muscular scar on both sides. From Tropidoleptus zone No. 1 in Enfield shale member of the Portage formation, same locality and collector as specimen of figure 6 . U. S. Nat. Mus. Cat. Nu. 59611.

FIGURE 9. Rhipidomella vanuxemi Hall. Mold of interior of a pedicle valve showing faint muscular impressions and strong median ridge separating the two lobes of the scar and produced forward beyond their front margin. The unsymmetrical form is probably due to movement in the rock matrix after fossilization. From Tropidoleptus zone No. 1 in Enfield shale member of the Portage formation (Ow. 9A, 1l, U. S. Geol. Survey); same stratum as figure 7. U. S. Nat. Mus. Cat. No. 59612.

Figure 10. Rhipidomella vanuxemi Hall. Mold of the interior of a pedicle valve, the cardinal angles of which are absent, showing the flattened surface of the shell, the fairly large fan-shaped nuscular scars, and the strong median ridge. From Tropidoleptus zone No. 1 in Enfield shale member of the Portage formation (Hd. 13G, 1r), Harford Mills section. L. Reinecke, collector. U. S. Nat. Mus. Cat. No. 59611.

FIGURE 11. Rhipidomella vanuxemi Hall. Mold of the interior of a pedicle valve of abnormally elongate form. The elongation affects the shape of the muscular scar as well as the outline of the shell and results in a forward development of the two inner lobes of the muscular scar of both sides. The ridges bounding the muscular scar and teeth plates are both strongly developed. From Tropidoleptus zone No. 1 in Enfield shale member of the Portage formation (Ow. 9 A, $1 m$, U. S. Geol. Survey), west of North Candor, Tioga County, N. Y. Y. H. Barnett, collector. U. S. Nat. Mus. Cat. No. 59613.

FigUne 12. Rhipidomella vanuxemi Hall. Mold of the interior of a brachial valve, showing the cardinal process, the rather strongly developed crural plates, and the narrow but strong ridge between the muscular scars. The shell 
U. S. GEOLOGICAL SURVEY
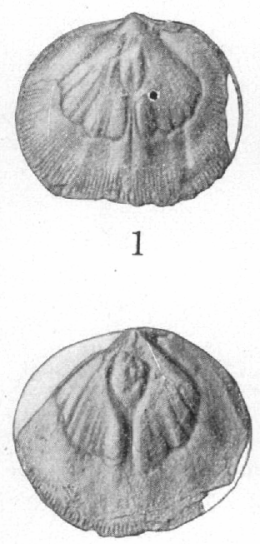

4

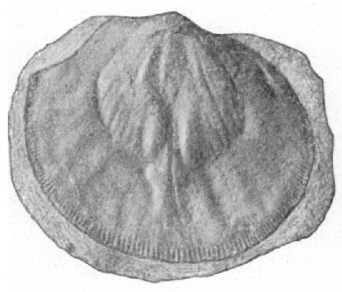

7

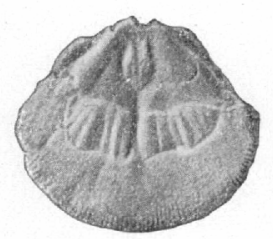

10

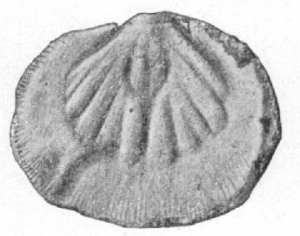

13

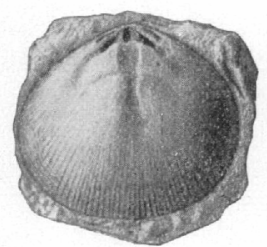

16

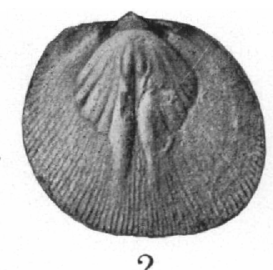

2
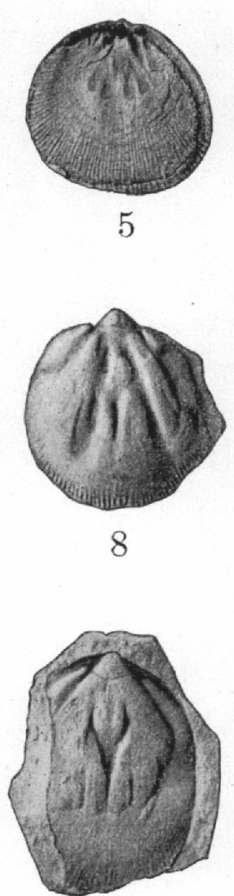

11

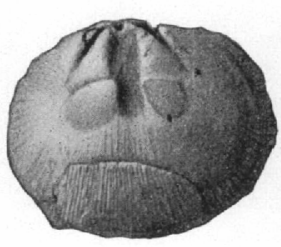

14

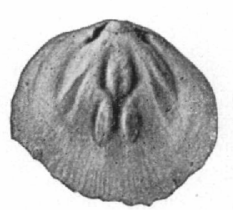

17
PROFESSIONAL PAPER T9 PLATE III

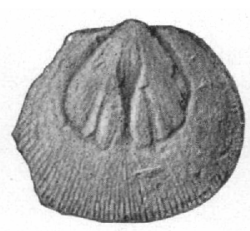

3

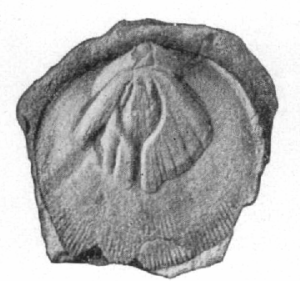

6

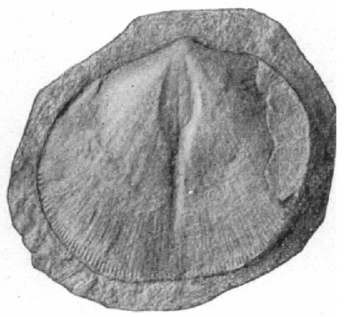

9

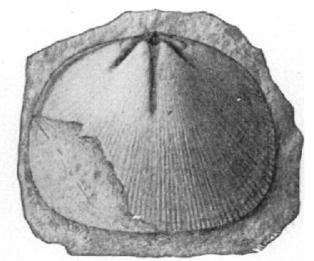

12

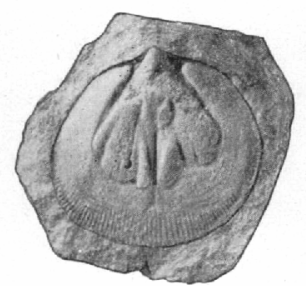

15

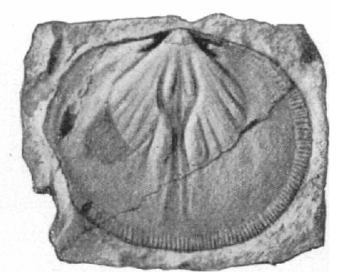

18

RHIPIDOMELLA VANUXEMI HALL AND VARIETIES, 

of the specimen is so thin as to show distinctly the radial lineation on the inner surface, and the muscular scar is so faintly expressed as to fail of observation. From Tropidoleptus zone No. 1 in Enfield shale member of the Portage formation (Hd. 13G, 1r), Harford Mills section. L. Reinecke, collector. U. S. Nat. Mus. Cat. No. 59611.

FigUre 13. Rhipidomella vanuxemi Hall. Mold of the interior of a pedicle valve, particularly broad, as in $R$. penelope. The muscular scar is large and fan-shaped; the ridges separating into lobes are strong, and the outside margins of the impressions are strongly expressed. The beak portion is broken off, giving the appearance of a more quadrate form than it actually had. The shell was slightly concave. From Tropidoleptus zone No. 3, in Cayuta shale member of the Chemung formation (Wv. 11H, 1a, U. S. Geol. Survey), North Chemung, Chemung County, N. Y., at altitude of 1,440 feet. E. M. Kindle, collector. U. S. Nat. Mus. Cat. No. 59614.

FIgURE 14. Rhipidomella vanuxemi Hall. Mold of the interior of the brachial valve of the specimen shown in figure 13, showing the convexity of the valve and near the front the original shell. This specimen well expresses the four parts of the adductor scar figured by Hall (Paleontology: Geol. Survey New York, vol. 8, pt. 1, Pl. VI, A, fig. 7). From Tropidoleptus zone No. 3 in Cayuta shale member of the Chemung formation; same location as figure 13 . U. S. Nat. Mus. Cat. No. 59614.

Figure 15. Rhipidomella vanuxemi Hall. Mold of the interior of a pedicle valve, showing the convex form of the cardinal side of the shell, flattened anteriorly, as in normal $R$. vanuxemi. The muscular scar is fan-shaped; the two middle lobes are strongly developed, and the hinge teeth strong. From Tropidoleptus zone No. 3 in Cayuta shale member of the Chemung formation (El. 1E, 1a, U. S. Geol. Survey), one-fourth mile southwest of Breesport, Chemung County, N. Y., at an altitude of 1,420 feet. U. S. Nat. Mus. Cat. No. 59615.

FIgURE 16. Rhipidomella vanuxemi Hall. Mold of the interior of a brachial valve, showing the cardinal process, crural plates, and the rather broad median ridge separating the faint impressions of the muscular scars. From Tropidoleptus zone No. 3 in Cayuta shale member of the Chemung formation (Wv. 7B, $1 j^{2}$ ), southwest of Swartwood station, near the summit of Austin Hill, in Chemung County, N. Y. C. L. Breger, collector. U. S. Nat. Mus. Cat. No. 59616.

FIGURE 17. Rhipidomella vanuxemi Hall. Mold of the interior of a pedicle valve of medium size, showing muscular scar with not strongly developed outside boundary ridges but with strong ridges dividing its lobes and strong median ridge. The surface form is convex in the umbonal part and flattened toward the front. From Tropidoleptus zone No. 3 in Cayuta shale member of the Chemung formation (Wv. $7 \mathrm{~B}, 1 j^{2}$ ), southwest of Swartwood Station, near summit of Austin Hill in Chemung County, N. Y. C. L. Breger, collector. U. S. Nat. Mus. Cat. No. 59616.

FIGURE 18. Rhipidomella vanuxemi Hall. Mold of the interior of a pedicle valve showing the wide form of $R$. leucosia. The form of the muscular scar is similar to that shown in figure 2 from the Ilamilton; the two slender grooves near the median line extend forward nearly to the front margin of the shell, as in figure 7. From Tropidoleptus zone No. 3 in Cayuta shale member of the Chemung formation (Wv. 11H, 1a), North Chemung, Chemung County, N. Y., at altitude of 1,440 feet. E. M. Kindle, collector. U. S. Nat. Mus. Cat. No. 59614. 

PLATE IV. 


\section{PLATE IV.}

\section{SPIRIFER Marcyi HaLl. aNd Varieties.}

FIGURE 1. Spirifer marcyi typicalis. Interior mold of a pedicle valve, showing the form, the surface plirations, the muscular scars and dental plates. From Tropidoleptus zone No. 3 in Cayuta shale member of Chemung formation (Wv. 7B, 1jjj), on Austin Hill south of Swartwood. C. L. Breger, collector. U. S. Nat. Mus. Cat. No. 59617.

FIGURE 2. Spirifer marcyi typicalis. Interior mold of hinge portion of the pedicle valve, showing the moderately elevated area, the strong dental plates, the transverse plate in the upper part of the cavity of the beak, and the faint indication of the rudimentary syringeal plates on the inner side of the dental plates. Same specimen as figure 1 . From Tropidoleptus zone No. 3 in Cayuta shale member of Chemung formation (Wv. 7B, 1jjj), on Austin Hill, south of Swartwood, N. Y. U. S. Nat. Mus. Cat. No. 59617.

FIgURE 3. Spirifer marcyi beta. Interior mold of a pedicle valve, showing the form, the surface plications, the muscular scar, the dental plates, and a median septum separating the anterior portion of the diductor muscular scars. From Tropidoleptus zone No. 2 in Cayuta shale member of Chemung formation, quarry on south side Cemetery Hill, Owego, N. Y. (1130A.) H. S. Williams, collector. U. S. Nat. Mus. Cat. No. 59618.

FIGURE 4. Spirifer marcyi beta. Interior mold of hinge portion of pedicle valve, showing the dental plates and the moderately high area. The dental plates are united near the apex of the umbonal cavity by a transverse plate. Specimen same as figure 3. U. S. Nat. Mus. Cat. No. 59618.

FIGURE 5. Spirifer marcyi beta. Interior mold of a crushed pedicle valve, showing the effect of crushing in distorting the form of the valve; compare with figure 3. From Tropidoleptus zone No. 2 in Cavuta shale member of Chemung formation, quarry on south side Cemetery Hill, Owego, N. Y. (1130A.) H. S. Williams, collector. U. S. Nat. Mus. Cat. No. 59618.

FIgURE 6. Spirifer marcyi beta. Interior mold of a pedicle valve, showing the area and slender short dental plates, with very short transverse plates. From Tropidoleptus zone No. 2 in Cayuta shale member of Chemung formation, cemetery quarry, Owego, N. Y. (1130A.) H. S. Williams, collector. U. S. Nat. Mus. Cat. No. 59618.

Figure 7. Spirifer marcyi gamma. Interior mold of a pedicle valve, showing the form, the high narrow beak, the short dental platee, the slight median septum, and the faint muscular scars. From Tropidoleptus zone No. 2 in Cayuta shale member of Chemung formation, cemetery quarry, Owego, N. Y. (1130A.) H. S. Williams, collector. U. S. Nat. Mus. Cat. No. 59619.

FIGURE 8. Spirifer marcyi gamma. Interior mold of pedicle valve; areal view, showing the high erect area, subparallel dental plates, short transverse plates, rudimentary syringeal plates near apex of the umbonal cavity, and vascular pitting of the interior of the hinge area. From Tropidoleptus zone No. 2 in Cayuta shale member of Chemung formation, cemetery quarry, Owego, N. Y. (1130A.) H. S. Williams, collector. U. S. Nat. Mus. Cat. No. 59619.

FiguRE 9. spirifer marcyi delta. Interior mold of pedicle valve, showing the form of the valve, the rudimentary dichotomizing of the plications near the middle of the valve, and the auxiliary plications on the slopes of the median sulcus. From Tropidoleptus zone No. 2 in Cayuta shale member of Chemung formation (El. 6L, 1q), quarry, 1 mile southwest of Southport, Chemung County, N. Y., at elevation of about 1,000 feet. E. M. Kindle, collector. U. S. Nat. Mus. Cat. No. 59620.

FIGURE 10. Spirifer marcyi sigma. Interior mold of the areal portion of a pedicle valve $(\times 2)$. The specimen, which is imperfect and somewhat crushed, belongs in form to var. beta. The specimen shows the dental plates united by a strong transverse plate, from which the two syringeal plates parallel to the dental plates are directed forward from the transverse plate, being developed down ward from the apical portion of the umbonal cavity. From Tropidoleptus zone No. 1 in Enfield shale member of Portage formation (Dr. 8I, 1c), White Church section, Caroline, Tompkins County, N. Y. C. L. Breger, collector. U. S. Nat. Mus. Cat. No. 59621. 
U. S. GEOLOGICAL SURVEY

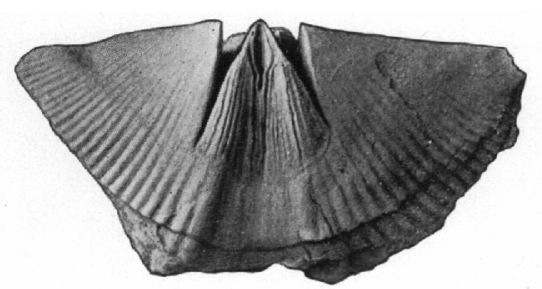

1

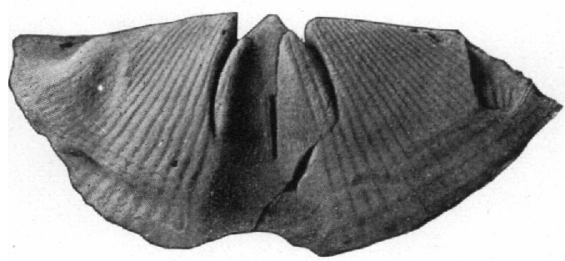

3

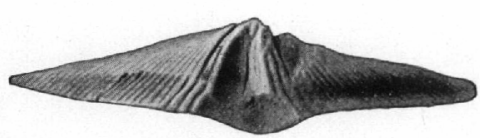

5
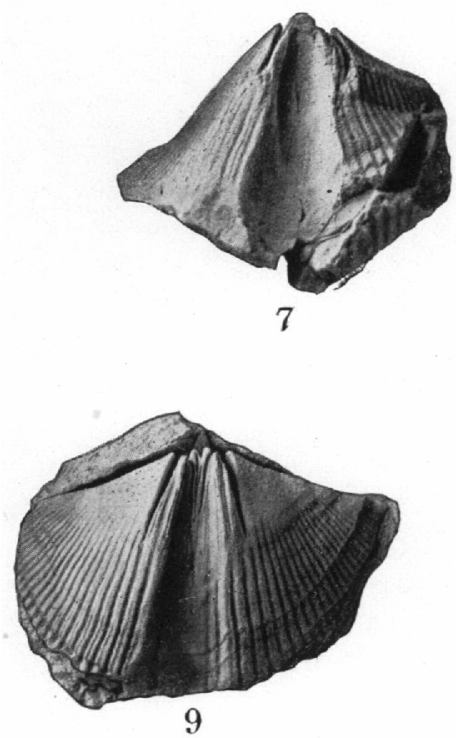

PROFESSIONAL PAPER 79 PLATE IV

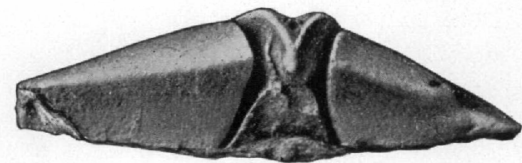

2
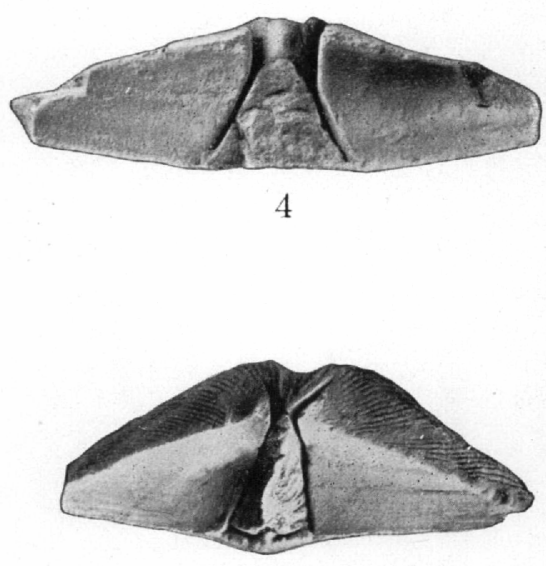

6

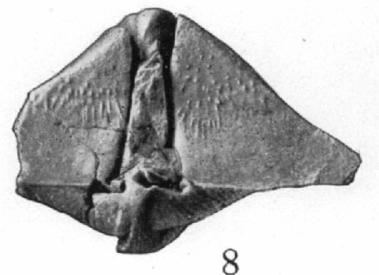

8

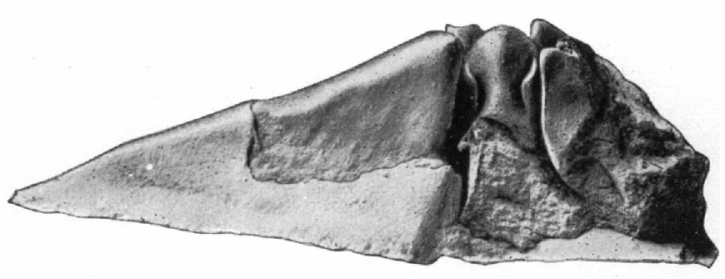

10

SPIRIFER MARCYI HALL AND VARIETIES. 

PLATE V. 


\section{PLATE V.}

\section{SPIRIFER AND SYRINGOTHYRIS.}

FraURe 1. Spirifer granulosus sigma. Internal mold of a pedicle valve, showing form, plications, faint muscular scar, and thin dental plates. From upper part of Hamilton formation, Smyrna, Chenango County, N. Y. (1066A ${ }^{3}$.) C. S. Prosser, collector. U. S. Nat. Mus. Cat. No. 59625.

Figure 2. Spirifer granulosus sigma. Opposite side of specimen shown in figure 1. From Smyrna, Chenango County, N. Y. $\left(1066 \mathrm{~A}^{3}\right.$.) $\quad$ U. S. Nat. Mus. Cat. No. 59625.

Figure 3. Spirifer marcyi gamma. Brachial valve of specimen shown in Plate IV, figures 7 and 8 . Internal mold of brachial valve, showing form, plications, and median fold. From Tropidoleptus zone No. 2 in Cayuta shale member of Chemung formation, cemetery quarry, Owego, N. Y. (1130A.) H. S. Williams, collector. U. S. Nat. Mus. Cat. No. 59619 .

Figure 4. Spirifer granulosus sigma. Same specimen as in figures 1 and 2. Internal mold of cardinal side of specimen, showing cardinal view of two valves united $(X 2)$. At the apex of the umbonal cavity is seen the twisted plate connecting the two dental plates and forming a rudimentary syrinx, which is more fully developed in typical specimens of Syringothyris. From upper part of Hamilton formation, Smyrna, Chenango County, N. Y. (1066A ${ }^{3}$.) C. S. Prosser, collector. U. S. Nat. Mus. Cat. No. 59625.

Figure 5. Spirifer marcyi beta. Mold of exterior surface of a brachial valve, showing plications and fold and the surface pustules $(\times 2)$. From Tropidoleptus zone No. 2 in Cayuta shale member of Chemung formation, cemetery quarry, Owego, Tioga County, N. Y. (1130A.) H. S. Williams, collector. U. S. Nat. Mus. Cat. No. 59618.

Figure 6. Syringothyris typa A. Winchell. Mold of interior surface of a pedicle valve and exterior surface of the hinge area. Showing the muscular scar, dental plates, and interior face of the cardinal area and narrow delthyrium. From early Mississippian, Carboniferous system, Smethport, Pa. (1471B ${ }^{6}$.) E. M. Kindle, collector. U. S. Nat. Mus. Cat. No. 59626 .

Figure 7. Syringothyris typa A. Winchell. Apical view of same specimen as figure 6 , showing a mold of the dental plates, connected at the apex of the umbonal cavity by the base of the twisted syringeal plates. This figure also shows the ridge connecting the syringeal plates with the median platform separating the posterior lobes of the adductor muscular scar. From early Mississippian, Carboniferous system, Smethport, Pa. (1471B ${ }^{6}$.) E. M. Kindle, collector. U. S. Nat. Mus. Cat. No. 59626.

Fiavre 8. Spirifer marcyi zeta. Mold of the exterior surface of a brachial valve (about $\times 2$ ), showing the narrow attenuated form, the addition to number of plications on the mucronated extension of the shell, and the pustules on the surface. From Tropidoleptus zone No. 2 in Cayuta shale member of Chemung formation (Wv. 7B, $1 p$ ), Swartwood, Chemung County, N. Y. C. L. Breger, collector. U. S. Nat. Mus. Cat. No. 59622.

Frgure 9. Spirifer marcyi epsilon. Mold of exterior surface (about $\times 3$ ), showing the exterior surface characters of a brachial valve, mucronate form. Of the numerous plications one near the left end of the figure is distinctly bifurcated. The pustules are also elongate, and show a tendency to form continuous longitudinal lines on the median fold. From Cayuta shale member of Chemung formation (EI. 2M, p4), Ashland Hill, south of Elmira in Ashland Township, Chemung County, N. Y., at 950 feet elevation. E. M. Kindle, collector. U. S. Nat. Mus. Cat. No. 59623.

FIGURE 10. Spirifer marcyi beta. Mold of interior of the brachial valve of the specimen figured on Plate IV, figures 5 and 6 . Showing the characteristic expression of var. beta (compare with figs. 3, 8, and 11). From Tropidoleptus zone No. 2 in Cayuta shale member of Chemung formation, quarry on south side of cemetery hill, Owego, Tioga County, N. Y. (1130A.) H. S. Williams, collector. U. S. Nat. Mus. Cat. No. 59618.

FIGURE 11. Spirifer marcyi typicalis. Mold of the interior of a large specimen, showing the interior of a brachial valve; the muscular scars and vascular pittings are sharply expressed. From Tropidoleptus zone No. 3 in Cayuta shale member of the Chemung formation, near the top of the ravine west of Spencer Lake, northwest of Spencer, Tioga County, N. Y. U. S. Nat. Mus. Cat. No. 59624.

FIGURE 12. Spirifer marcyi epsilon. Interior mold of specimen shown in figure $9(\times 2)$. Showing the form and plication. One of the plications on the right end of the specimen is bifurcated. From Cayuta shale member of Chemung formation (El.2M, $p^{4}$ ), Ashland Hill, south of Elmira in Ashland Township, at elevation of 950 feet. E. M. Kindle, collector. U. S. Nat. Mus. Cat. No. 59623.

FIGURE 13. Spirifer marcyi delta. Mold of exterior surface of pedicle valve of specimen represented in Plate I, figure 9. Showing the rudimentary duplication of the plications, the surface pustules, and the supplementary plications on the sides of the sulcus. From Tropidoleptus zone No. 2 in Cayuta shale member of Chemung formation (El. 6L, $1 \mathrm{q}$ ), quarry 1 mile southwest of Southport, Chemung County, N. Y., at elevation of 1,000 feet. E. M. Kindle, collector. U. S. Nat. Mus. Cat. No. 59620. 


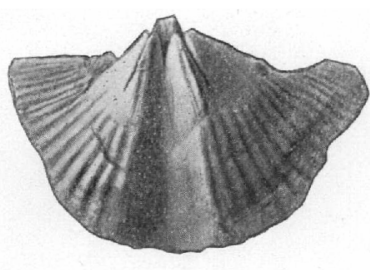

1
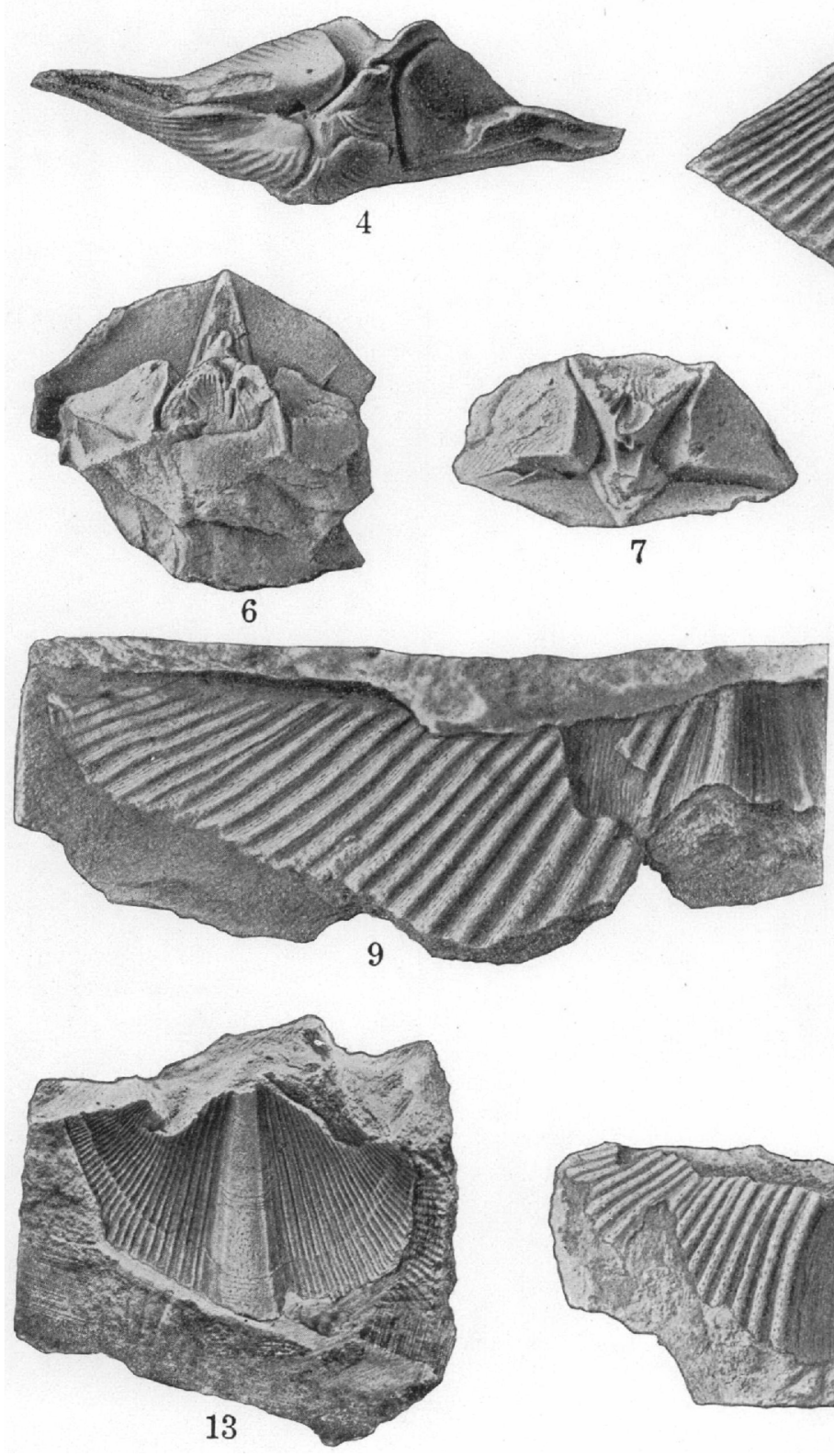

SPIRIFER AND SYRINGOTHYRIS.
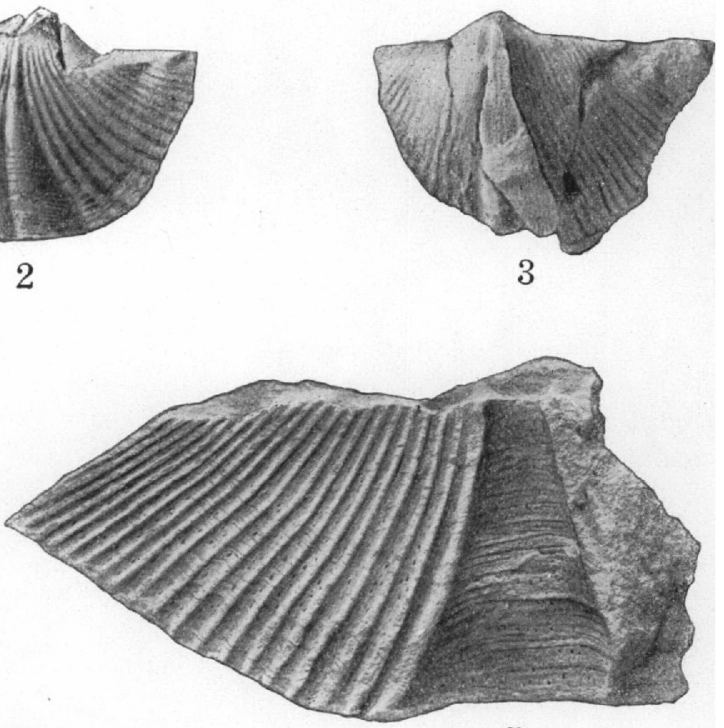

5
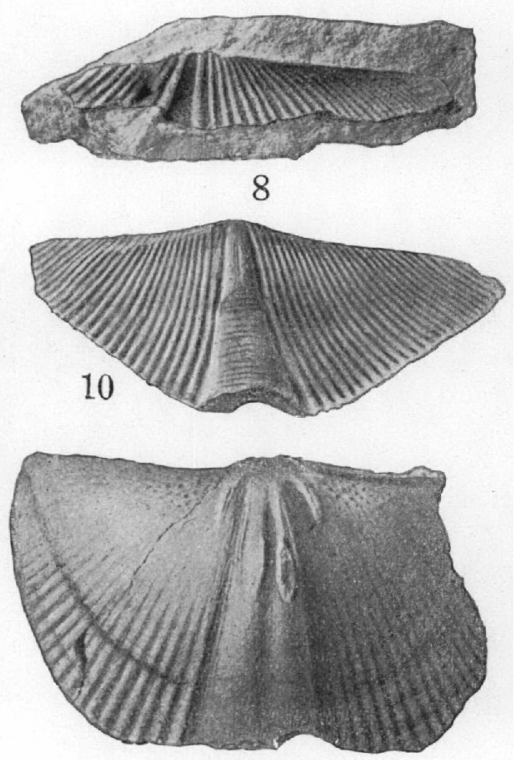

11

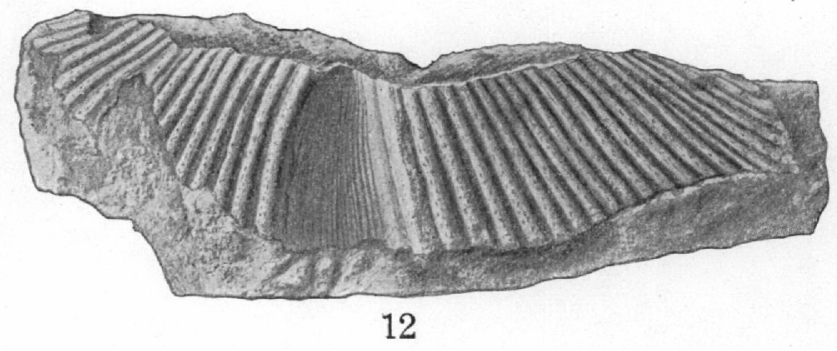





\section{PLATE VI.}




\section{PLATE VI.}

\section{Cypricardella belistriati (C'onrad).}

Figures 1-6, 8, 14. Specimens from the Iamilton formation at Sheldrake ravine, (ayuga Lake. U. S. Nat. Mus. Cat. No. 59627.

Figures 7, 9-12. Specimens from the Ithaca shale member of the Portage formation, Ithaca, N. Y. U. S. Nat. Mus. Cat. No. 59628

Figures 13, 15-18, 21. Specimens from the recurrent Tropidoleptus zone No. 2 in the cayuta shale member of the Chemung formation, Owego, Tioga County, N. Y. U. S. Nat. Mus. Cat. No. 59629.

Frgures 19, 20. Specimens from Tropidoleptus zone No. 3 at the top of the ('ayuta shale member of the ('hemung formation, Austin Hill, southwest of Swartwood, Chemung county, N. Y. C. S. Nat. Mus. Cat. No. 59630. 
U. S. GEOLOGICAL SURVEY

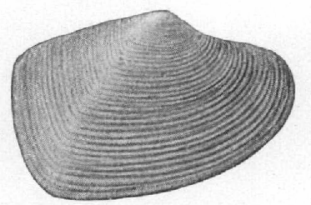

1

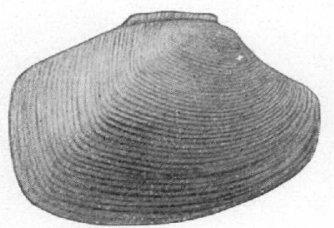

5

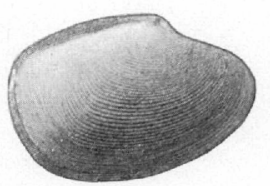

9

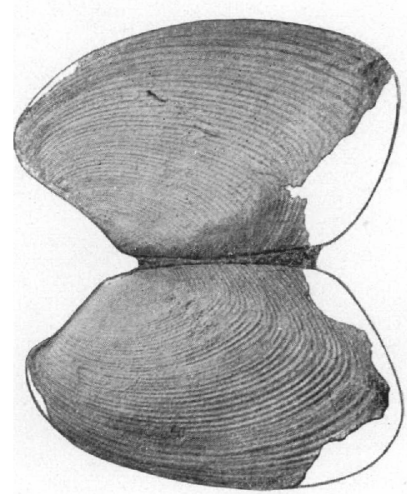

14

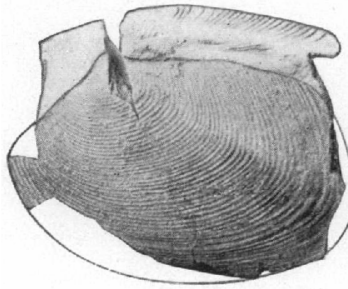

18

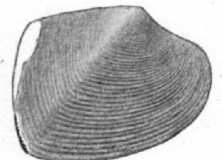

2

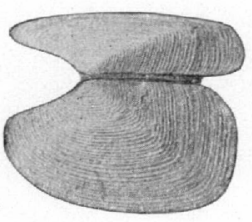

6

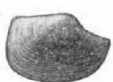

10

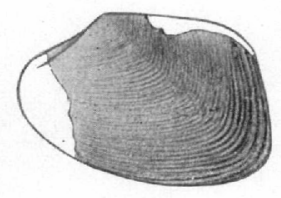

15
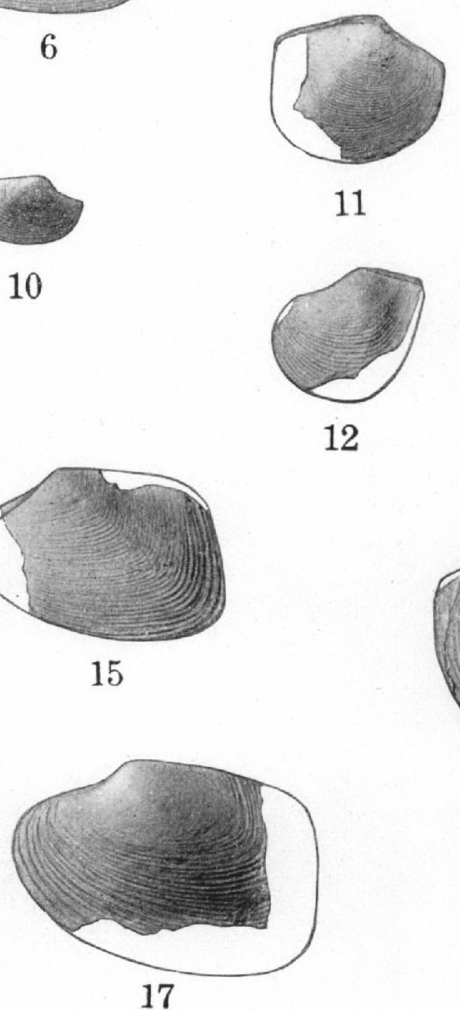

PROFESSIONAL PAPER 79 PLATE $V I$

11

12

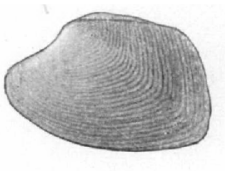

3
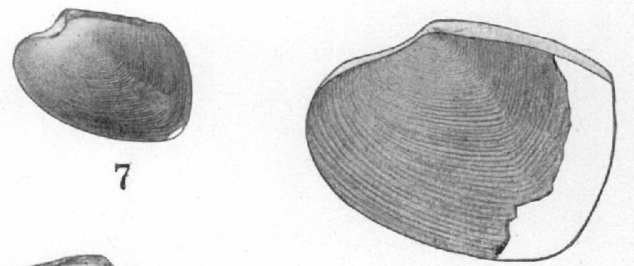

8

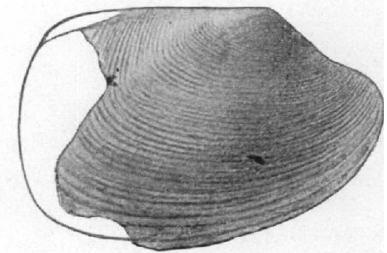

13

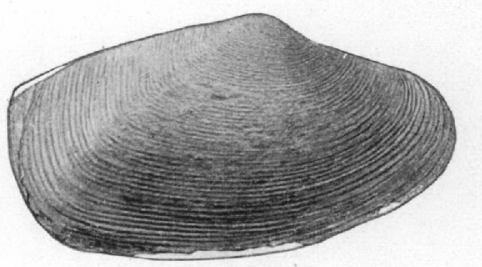

16

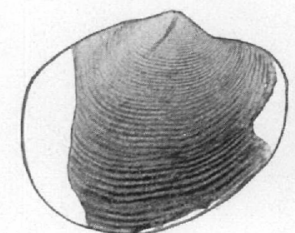

20

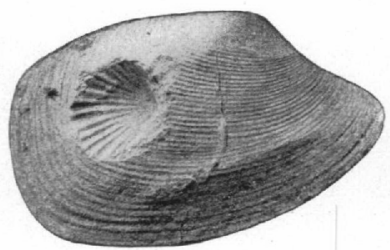

19

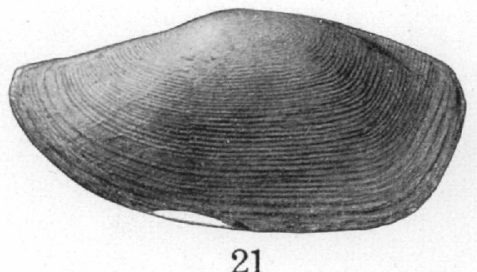

CYPRICARDELLA BELLISTRIATA (CONRAD). 



\section{INDEX.}

Figures in italic refer to illustrations.

A.

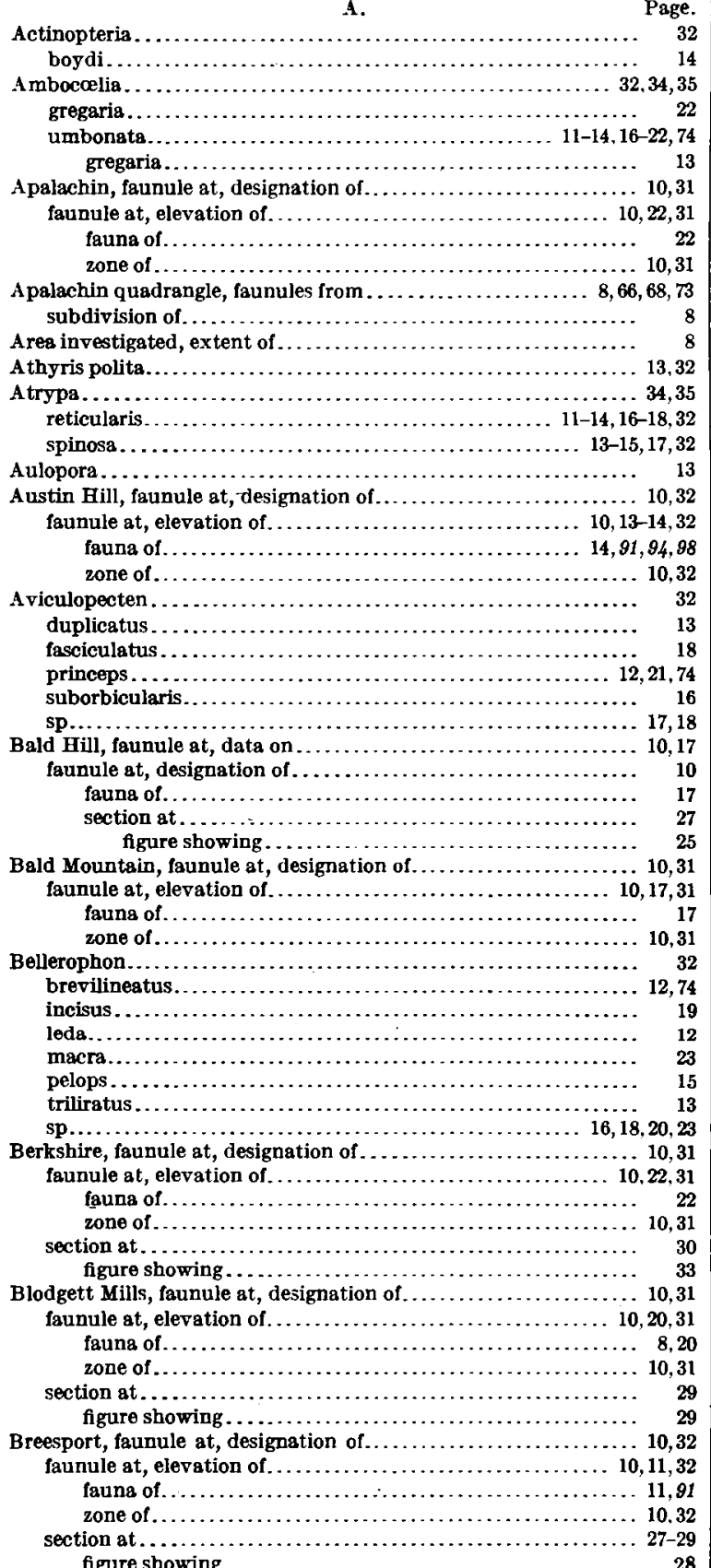

Page. ........26-27 section at, figure showing ............................. Buttermilk Creek ravine (B), fauna in....................... $31,32,90$ $34,35,36,67-68,73$ congregata. .............................. 16, 19,20,32,67-68 contracta......................... 11, 13-15, 18,20,21,32,67-68 eximia................................. 16-18, 20-22,67-68 eximia-stephani..................................... $67-68$ sappho........................... $11-13,15,16,19,21,22,32,67-68$ stephani........................................ 12,14,67 sp..................................... 17, 18, 20,22 Camarotณchia genus, occurrence of............. 11-22,32,34-36,67-68,73

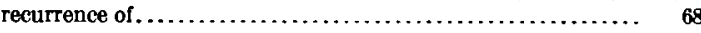
specific diserimination of . . . . . . . . . Cascadilla Creek (C), fauna at............................ 31, 32,63 Catatonk, section at.

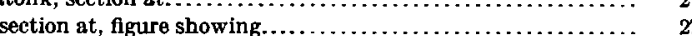

Catatonk quadrangle, location and parts of.................. 8 section in, figure showing.......................... See also Dryden; Harford; Owego; Apalachin quadrangles.

Cayuta, faunule at, designation of ....................... 10,31 faunule at, elevation of $\ldots \ldots \ldots \ldots \ldots \ldots \ldots \ldots \ldots \ldots \ldots, 10,12,31$

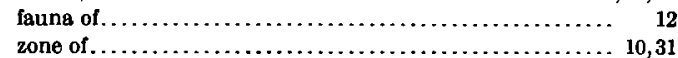

Cayuta shale member, recurrent zones in................. 7 section of, figure showing........................... See also Tropidoleptus zones.

Center Lisle, faunule at, designation of . . . .................. 10,31

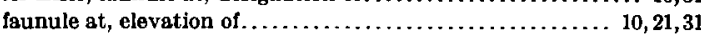

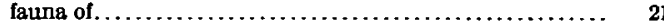
zone of $\ldots \ldots \ldots \ldots \ldots \ldots \ldots \ldots \ldots \ldots \ldots \ldots \ldots \ldots \ldots \ldots \ldots \ldots, 10,31$

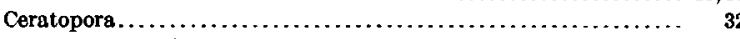
chemungensis................................... 13 Chemung formation, recurrent zones in..................... recurrent zones in, figures showing .................. 23-30 See also Cayuta shale member; Ithaca shale member.

Chenango Valley, section in, figure showing.................

Chonetes........................................... 34, 35

deflectus............... scitulus................................. 11, 13-18,20,21

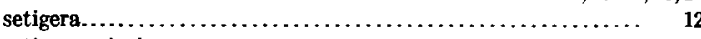
setigera-scitulus................................. 18 sp....................................... 11, 16, 18, 23 Cladochonus ........................................, sp......................................... 13, 18, 19 Coleolus..............................................

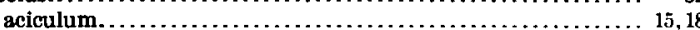

Conrad, T. A., cited.................................... 36

Conularia............................................ 32

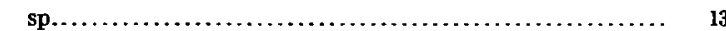
Cortland quadrangle, faunules from $\ldots \ldots \ldots \ldots \ldots \ldots \ldots \ldots \ldots, 8,66,68,73$ sections in ............................................. figure showing...........................

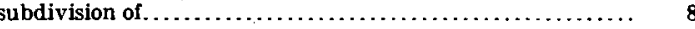

Crania leoni . . . . . . . . . . . . . .

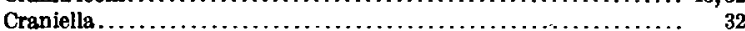

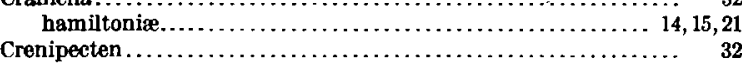

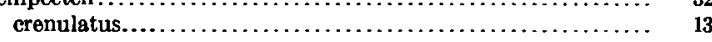

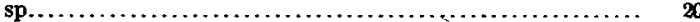




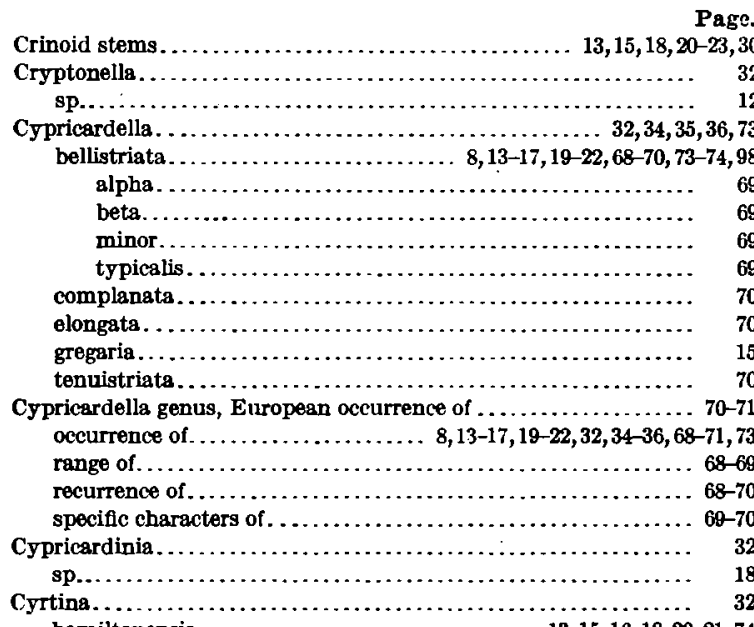

$13,15,16,18,20,21,74$

\section{D.}

Dalmanella $32,34,35$ carinate. elmira. tioga.

Dalmane 28 position of, figures showing..

Dalmanella tioga zone, position of, figure showing.

Deans Tannery, section at. section at, flgure showing. .

Delthyris.

consobrinus. mesicostalis recurrence of. specific characters of

Deposition, time relations of .

Deputron Creek, faunule at, designation of . faunule at, elevation of fauna of. fauna

Devonian system, recurrent zone in.

Diastrophism, evidence of. .

explanation of.

time relations of.

Douvillina cayuta.

Dryden Lake, faunule at, designation of

faunule at, elevation of

$$
\text { fauna of. }
$$
zone of

Dryden quadrangle, faunules from. section in...

figures showing

subdivision of

East Branch, section at. $24,27-28,29$ $23,25,26,28$ ......................

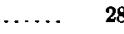
.....................

. $32,34,35-36,73,70-77$ $20,66-67,76$ $8,11-23,32,34,35-36,65-67,73$ $66-67,77$ 65-66 83-84 10,31 $0,18,31$

8

section at, figure showing.:

East Danby, faunule at, designation of

faunule at, elevation of. fauna of. zone of...

East Elmira, faunule at, designation of faunule at, elevation of fauna of. zone of...

East Virgil, section at. section at, figure showing

Edmondia phillipi.

Elmira, faunule at, designation of faunule at, elevation of. fauna of. section in. figure showing.
Elmira quadrangle, faunules from Page.

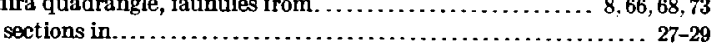

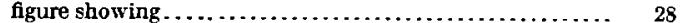
subdivision of

Enfield shale member, recurrent zone in ..................... section of, figure showing............................ 23 See also Tropidoleptus zone No. 1.

Euomphalus.

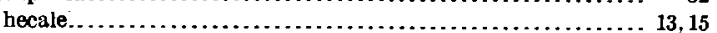

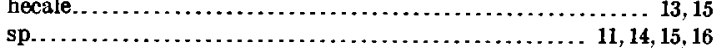
Euthydesma. ....................................... subtextilis.......................................

F. section at, figure showing.................................... Fauna, classification of ................................

grouping of by areas. ....................... 73 by species and genera........................... 32-33 identification of .................................. recurrence of, evidence of. ....................... $75-79,84$

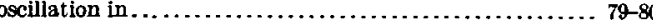
significance of .................................... $80-84$ See also Recurrent zones; Diastrophism.

time relations of............................... $83-84$

Faunules, altitudes of, determination of.....................

diagnostic genera of . . . . . . . . . . . . . . . . . . . . .

elimination of .....................................

fauna of . . . . . . .

geographic distribution of .......................... \& \&-10

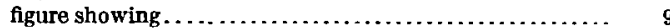

grouping of, by areas. . . . . . .

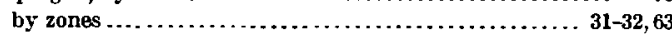

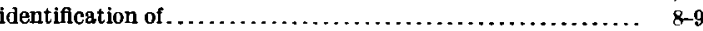

list of ...............................

species in .................................. 10-63

stratigraphic positions of ........................................ $23-24$ figures showing.................................... 24-30,33 See also particular faunal localities.

Fenestella...........................................

sp.................................................. 13

itches Bridge, faunule at, designation of ............... 10,31,32

faunule at, elevation of . . . . . . . . . . . . . . . . . . . 10, 11,31,32 fauna of ...................................... 11

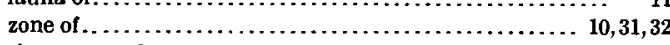

Fluctuation, range of.............................. $76-77$

See also Tropidoleptus; Rhipidomella; Spirifer marcyi.

G.

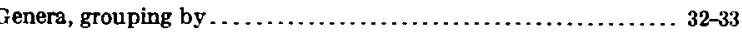

Gens, definition of.......................................

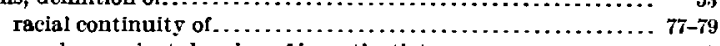

Geography, ancient, bearing of investigation on............. 7

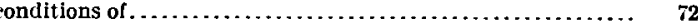
change in ..................................... $79-80$

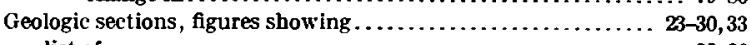

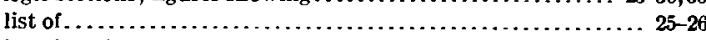

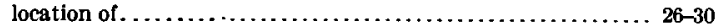

Glenwood, section at................................. 20

section at, figure showing . . . . . . . . . .

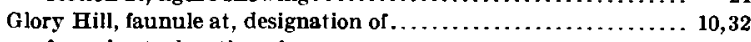

faunule at, elevation of $\ldots \ldots \ldots \ldots \ldots \ldots \ldots \ldots \ldots \ldots \ldots, 10,16,32$

fauna of ..................................... 16

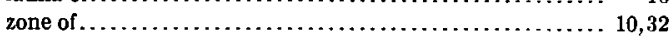

section at, figure showing . . . . . . . . . . figure showing $. \ldots \ldots \ldots \ldots \ldots \ldots \ldots \ldots \ldots \ldots \ldots \ldots \ldots \ldots \ldots \ldots, 26$

Glossites.............................................. 32

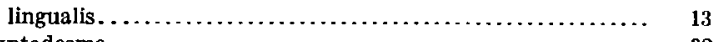

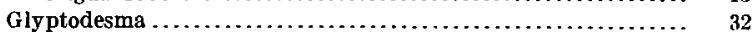

erectum.............................. 21,74

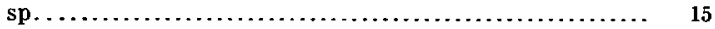

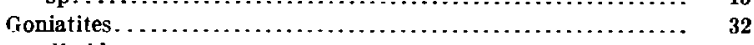

disoideus........................................ 12

Goniophora...................................... 32

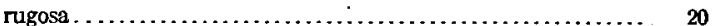

Gosselet, method of ............................. 44, 56-58

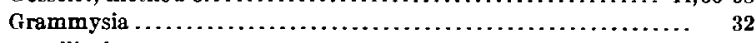
elliptica..........................................

subarcuata ................................... 13,21

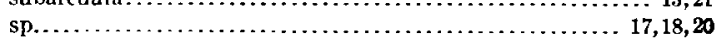




\section{H.}

Hall, James, cited.

$37,38-41,50-53$ Hamilton formation, fauns from. . . . . . . . . . . . . $36-72,88,90,96,98$

Hamilton shale, recurrence of, figure showing. See also Recurrent zones.

Harford, section at. section at, figure showing

Harford Mills, faunule at, designation o faunule at, elevation of. fauna of . ............................. $21,38-41,86,88,90-91$ zone of .

10,31 section at

figure showing

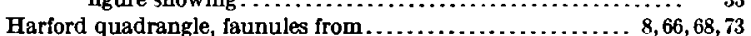
sections in. figures showing $\ldots \ldots \ldots \ldots \ldots \ldots \ldots \ldots \ldots \ldots \ldots \ldots, 29,30,33$ subdivision of.

Hawley Hill, section at.

section at, figure showing.

(t)

I.

Ithaca, faunule at, designation of....................... 10,31 faunule at, elevation of .............................. 10,12,31 fauna of $\ldots \ldots \ldots \ldots \ldots \ldots \ldots \ldots \ldots \ldots \ldots \ldots \ldots \ldots \ldots, \quad 12$

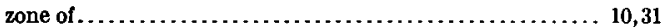

Ithaca quadrangle, faunules from..................8, 66, 68,73 sections in.

24,25 subdivision of.

Ithaca shale member, recurrent zone in section of, figure showing.

- See also Tropidoleptus zone of Ithaca shale member.

K.

Killawog, section at section at, figure showing

\section{L.}

Lapeer, faunule at, designation of fauna of. zone of.

Latty Brook, section at. section at, figure showing

Leda.

sp..............

Leiopteria.

conradi.

greeni.

mitchelli.

rafinesqui

sayi sp...

Leiorhynchus. mesicostale

multicosta. sinuatum.

Leiorhynchus globuliforme zone, position of position of, figure showing.

.

podesma.

agassizi.

creon...

extenuatum.

lichas.....

mortoni.

potens

20

20
10,31 $27-29$$$
\text { sp... }
$$

Leptostrop

Limoptera. .

$$
\text { macroptera. }
$$

Lingula

complanata.

spatulata

Lisle, faunule at, designation of . . . . . . . . . . faunule at, elevation of.

fauna of.

$$
\text { zone of }
$$

section at

figure showing.
Page.

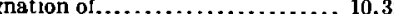
nule at, elevation of . .......................... 10,15,32 fauna of ......................................... 15

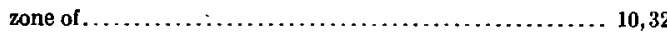

Lockwood, west, faunule at, designation of................ 10,32 faunule at, elevation of .......................... 10,15,32

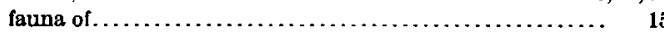
zone of .......................................... 10,32

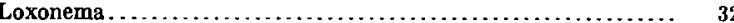

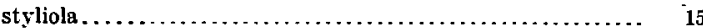
terebra. . . . . . . . . . . . sp $\ldots \ldots \ldots \ldots \ldots \ldots \ldots \ldots \ldots \ldots \ldots \ldots \ldots \ldots \ldots \ldots \ldots \ldots \ldots \ldots \ldots \ldots \ldots, 14-16,19,20,23$

Lyriopecten ...................................... suborbicularis................................... 14

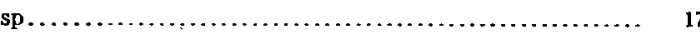
M.

Macrocheilina macrostoma.............................. 12, 15, 19, 23,74

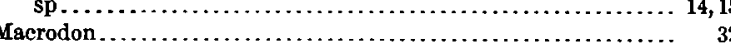

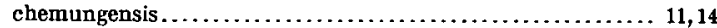

hamiltoniæ................................ 19, 7

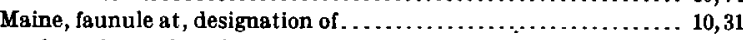

faunule at, elevation of ........................... 10,22,31

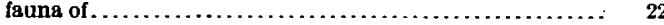

zone of $\ldots \ldots \ldots \ldots \ldots \ldots \ldots \ldots \ldots \ldots \ldots \ldots \ldots \ldots \ldots \ldots \ldots \ldots \ldots \ldots, 22,31$

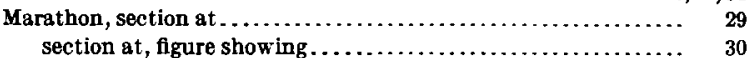

section at, figure showing...........................

Messengerville, faunule at, designation of . ........ 10,31

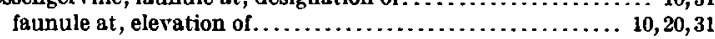
fauna of $\ldots$

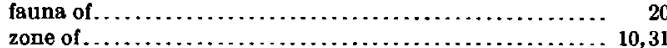

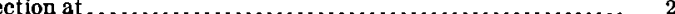

figure showing $\ldots \ldots \ldots \ldots \ldots \ldots \ldots \ldots \ldots \ldots \ldots \ldots \ldots \ldots \ldots, 29$

Modiella ......................................... 32

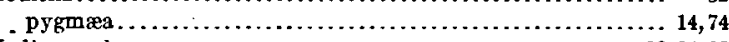

Modiomorpha..................................... 32,34,35

concentrica. .................................. 14, 20,74

macilenta..................................... 19

mytiloides . . . . . . . . . . . . . . .

neglecta..................................... 11, 12

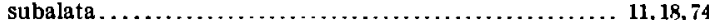

sp................................... 11-14, 16-19,22

Monotrypa sp...................................... 13, 32

Monotrypella $\ldots \ldots \ldots \ldots \ldots \ldots \ldots \ldots \ldots \ldots \ldots \ldots \ldots \ldots \ldots \ldots, \quad 32$

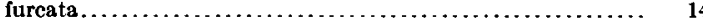

Mount Pleasant, faunule at, designation of ................ 10,31

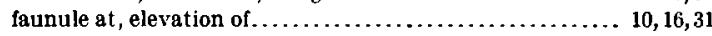
fauna of....................................... 10

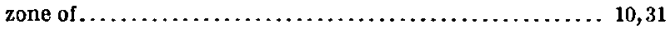

Murchisonia. sp ........................................... 15

Muscular scar of pedicle valve, shape of, ratio index of ..... 47 size of, ratio index of ............................ $46-4 i$ $\mathbf{N}$

Narrow Hill, faunule at, designation of $\ldots \ldots \ldots \ldots \ldots \ldots \ldots \ldots .10,32$

faunule at, elevation of $\ldots \ldots \ldots \ldots \ldots \ldots \ldots \ldots \ldots \ldots \ldots \ldots \ldots \ldots \ldots, 15,32$

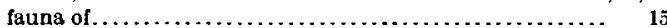

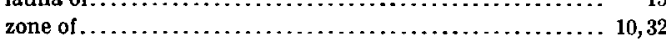

Nobles Hill, faunule at, designation of .................... 10,32 faunule at, elevation of ............................... 13, 32

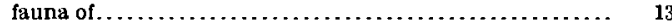

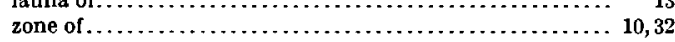

Nomenclature, method of $\ldots \ldots \ldots \ldots \ldots \ldots \ldots \ldots \ldots \ldots \ldots \ldots \ldots$
North Candor, faunule at, designation of $\ldots \ldots \ldots \ldots \ldots \ldots \ldots \ldots \ldots$
$\mathbf{1 0}, 31$

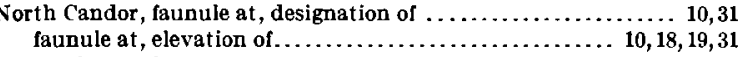
fauna of ...

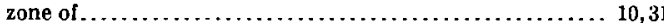

section at ..................... 27 figure showing $\ldots \ldots \ldots \ldots \ldots \ldots \ldots \ldots \ldots \ldots \ldots \ldots \ldots \ldots \ldots, 27$

North Chemung, faunule at, designation of ................ 10,32

faunule at, eleration of ............................. 10,14,32 fauna of......................................... zone of $\ldots \ldots \ldots \ldots \ldots \ldots \ldots \ldots \ldots \ldots \ldots \ldots \ldots \ldots \ldots, 10,32$

Nucula..

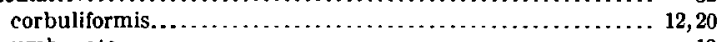

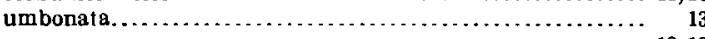

sp............................................. 12,19 
o.

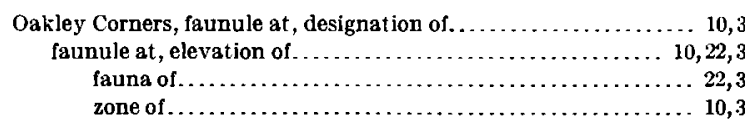

Orbiculoide

elmira.

sp......................................... 13, 14,16-18

Orthoceras

bebryx

sp.

faunule at, elevation of......................10,19, 20,32 faung or. zone of.

Owego, faunule at, designation of . . . . . . . . . . . . . . . . . . . . . faunule at, elevation of ........................ 10, 19,31

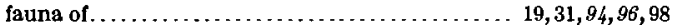
zone of ..................................... 10,31

Owego quadrangle, faunules from................. $8,66,68,73$ sections in.

figure showing. subdivision of.

Owego zone, name of. See also Tropidoleptus zone No. 2

Palæoneilo bisulcata.

brevis. plana. . .

constricta

plana .

sp.

Paloogeography. See Geography, ancient.

Paracardium. doris.

Paracylas tenuis

Paracyclas lirata zone, position of. position of, figure showing.

Pedicle valve, muscular scar of. Sec Muscular scar

Phacops rana.

Phthonia cylindrica.

Platyceras.

conicum erectum. sp............ $13,14,1 ;, 18,20,22$

sp...........
Pleurotomaria. capillaria. sp. $8,17,19,32,74$

$11,32,74$

$12,17,18$

$12,18,20$

(

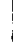

$14:$

$\mathrm{s}$
Portage formation, recurrent zones in recurrent zones in, figures showing See also Enfield shale member; Ithaca shale member.

Productella

boydi.

hirsuta......

lacrymosa. stigmata.

rectispina.

speciosa.

spinalicosta sp...

Pterinea.

chemungensis

consimilis.

flabellum

reversa.

R.

$$
7
$$
73 1,32
7,32 20,32 18
32 , 32 1,32 32,35
17,22 32

Racial continuity, evidence of . . . . . . Ratio indexes, scheme of.

Recurrence, discovery evidence of. reliability of.

Recurrent zones, fauna of.

fauna of, grouping of. $34-36,72-73,75-79$

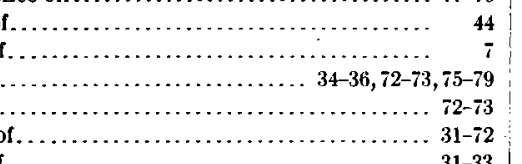

Recurrent zones, stratigraphic positions of $, \ldots \ldots \ldots \ldots \ldots \ldots, \quad \begin{array}{r}\text { Page. } \\ 7,23-30\end{array}$ figures showing......................... 23-30,33

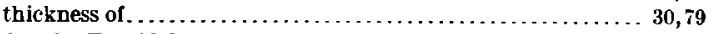

See also Tropidoleptus zones.

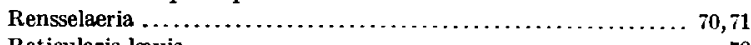

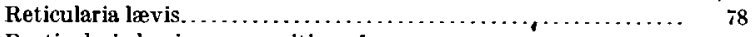

Recticularia levis zone, position of ......................... 26

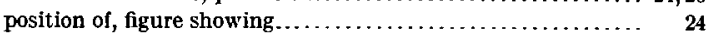

Rhipidomella......................... $32,34,35,36,42-50,65,72-75,77$ cyclas................................. $4 \mathbf{4 5}$

hybrida...........................................

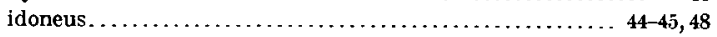

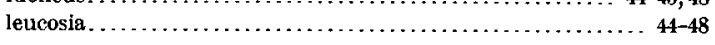

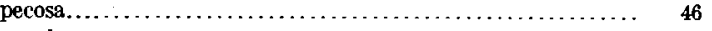

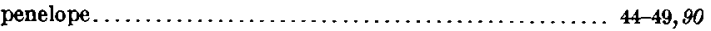

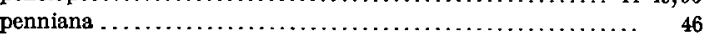

vanuxemi..................... 8,11-19,21,22,41-47,49,73, 90-91

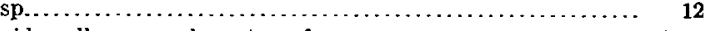

Rhipidomella genus, characters of . . . . . . . . . . . . . . .

characters of, ratio indexes of........................ 44-47

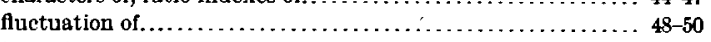

investigation of, scope of ........................ 43

occurrence of. .................. 8,11-19, 21, 22,32,34,35,36, 70-77

by quadrangles................................ 42

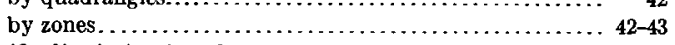

specific discrimination of ............................. 47-50

artificiality of . . . . . . . . . . . . .

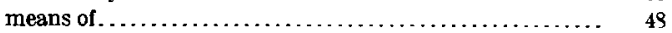

specimens of, measurement of . ........................ 43-47

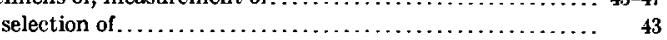

Rugose corals.................................... $\quad 32$

S.

Schizodus. . . . . . . . . . .

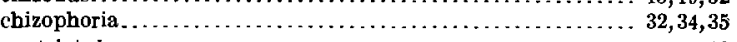

striatula .....................................18

Schuchert, Charles, on Alleghania .................... 72

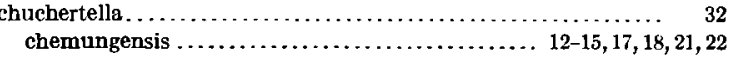

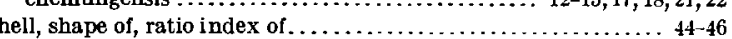

Sherburne member, section of, figure showing ............... 23

outhport, faunule at, designation of . ................... 10,13

faunule at, elevation of ............................ 10,12,31 fauna of ............................... 12,31,94,96 zone of $\ldots \ldots \ldots \ldots \ldots \ldots \ldots \ldots \ldots \ldots \ldots \ldots \ldots \ldots \ldots \ldots \ldots \ldots \ldots \ldots, 31$

pathella............................................ 32

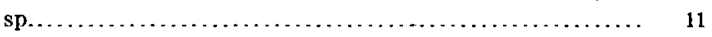

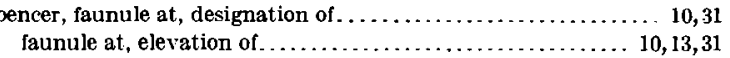

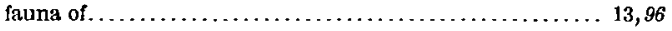

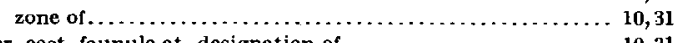

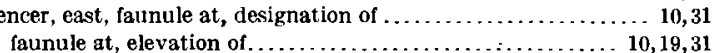
fauna of $\ldots \ldots \ldots \ldots \ldots \ldots \ldots \ldots \ldots \ldots \ldots \ldots \ldots \ldots, 19$ zone of $\ldots \ldots \ldots \ldots \ldots \ldots \ldots \ldots \ldots \ldots \ldots \ldots \ldots \ldots \ldots \ldots \ldots \ldots \ldots \ldots \ldots \ldots \ldots, 10,31$

Spencer Lake ravine, faunule at, designation of . . . . . . . . . . . 10,31

faunule at, elevation of .................................... 10,12,13,31 fauna of . ................................ 12 13,41-42 zone of ..................................... 10,31

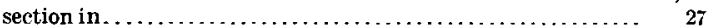
figure showing......................................

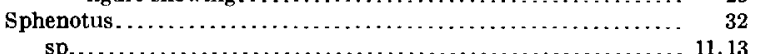

sp $\ldots \ldots \ldots \ldots \ldots \ldots \ldots \ldots \ldots \ldots \ldots \ldots \ldots \ldots \ldots \ldots \ldots \ldots \ldots \ldots \ldots \ldots \ldots \ldots \ldots \ldots$
59

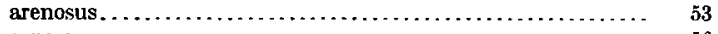

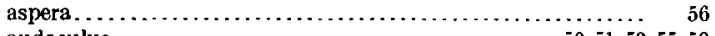

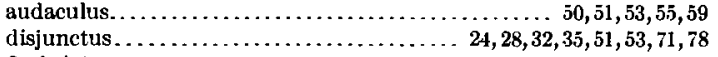
fimbriatus............................................ $17,22,32,74$

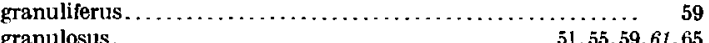

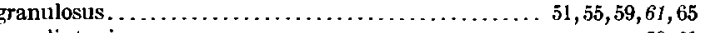
clintoni .................................. 59,61

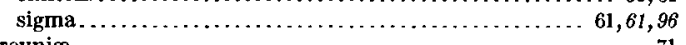
hercyniæ.......

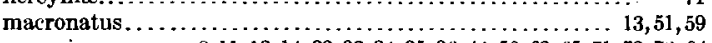

marcyi......... 8, 11,12,14-22,32,34,35,36, 44, 50-63, (5.5, 71, 73-78, 94 alpha.............................

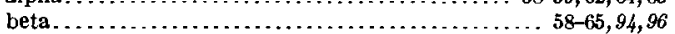


INDEX.

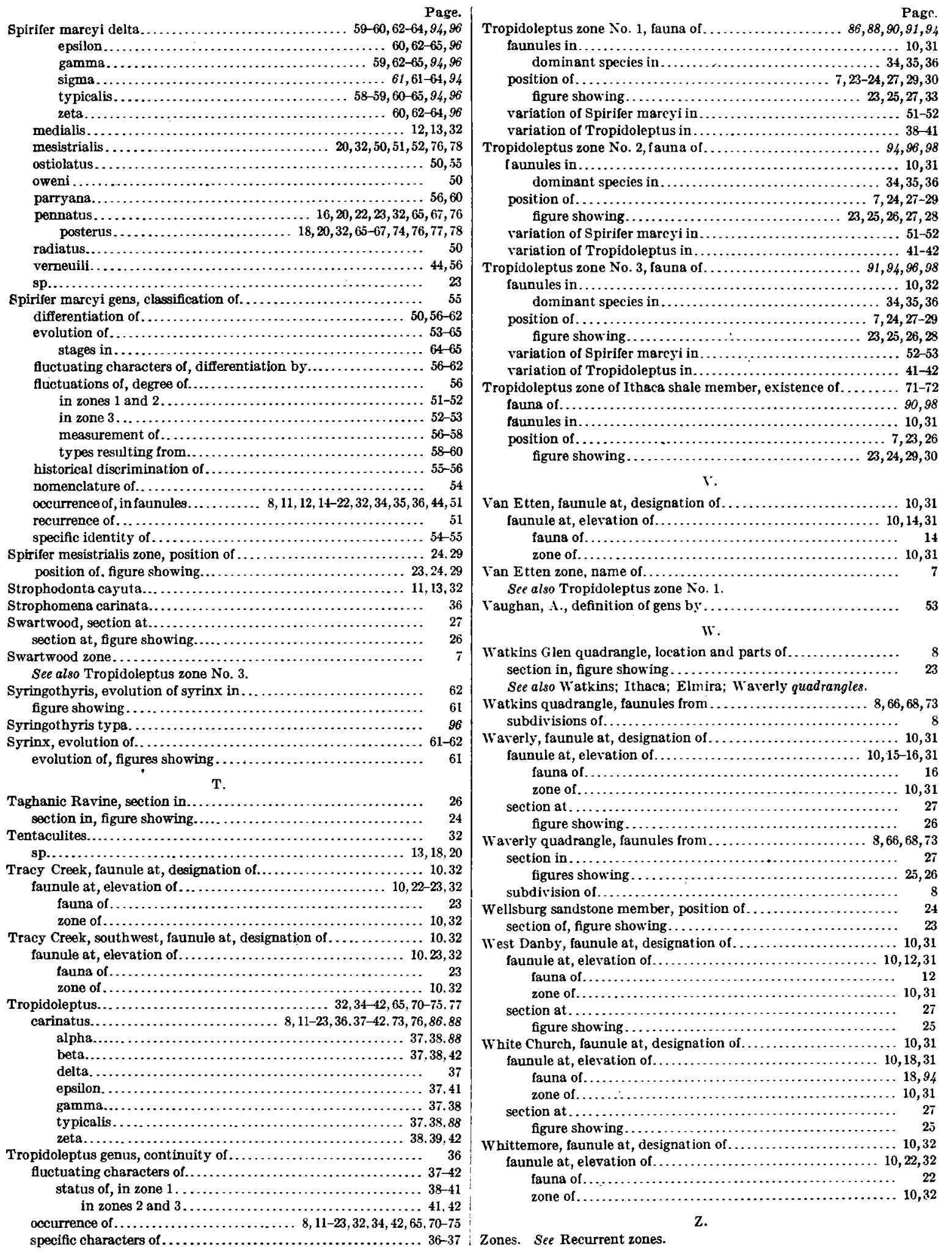


